Szegedi Tudományegyetem

Természettudományi és Informatikai Kar

Földtudományok Doktori Iskola

Gazdaság- és Társadalomföldrajz Tanszék

\title{
A MAGYARORSZÁGI APRÓFALVAK SIKERESSÉGI TÉNYEZÖINEK VIZSGÁLATA
}

Doktori (Ph.D.) értekezés

Józsa Klára

Témavezető

Dr. Bajmócy Péter

egyetemi docens

Szeged

2014 


\section{TARTALOMJEGYZÉK}

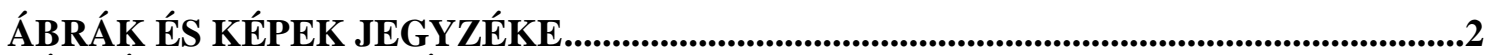

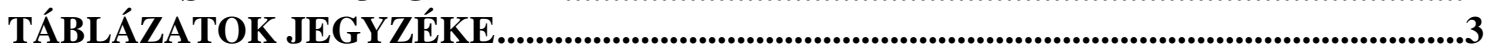

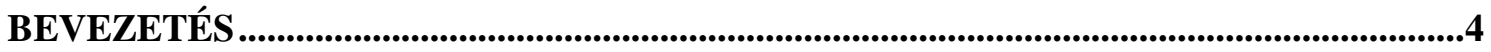

1. A dolgozat célja, kérdései, alkalmazott módszerei, kutatási terület.....................................4

1.1. A hazai aprófalvak vizsgálata során felmerülő problémák, a kutatás aktualitása,

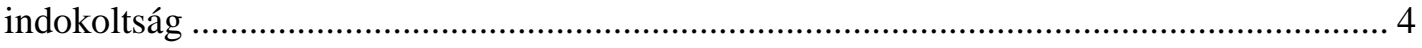

1.2. A kutatás kérdései, hipotézisei, céljai, a disszertáció logikai váza ................................. 7

1.3. A disszertációban alkalmazott kutatási módszertan ...................................................... 10

2. Szakirodalmi elméleti keretek, fogalmak................................................................22

2.1. Az aprófalu fogalma, az aprófalvas településállomány területfejlesztési aspektusai,

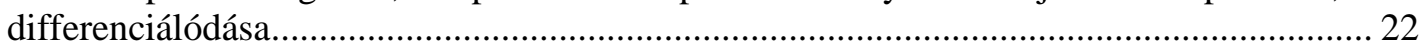

2.2. A sikeresség tényezőinek lehatárolása a települési sikerfogalmak vizsgálatán

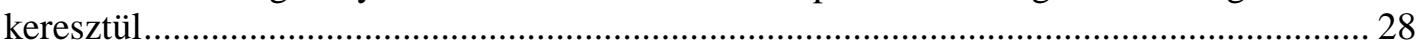

3. Az aprófalvak sikerességi tényezői ,kívülrőll” szemlélve..........................................................37

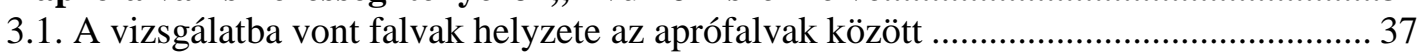

3.2. A vizsgálatba vont falvak helye összfejlettségi adataik alapján az összes falu

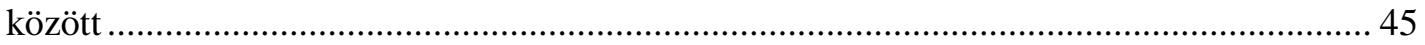

3.3. A 2011-es népszámlálási adatok módosító hatása a falvak fejlettségi értékeire ............ 52

3.4. A vizsgálatba vont falvak utcaképe, épületállománya ....................................................58

4. A sikeresség tényezői „,belülről”, a lakosság és a helyi elit véleményének tükrében .......................................................................................................................................................63

4.1. Lakossági vélemények a vizsgálatba vont településekröl, azok sikerességi

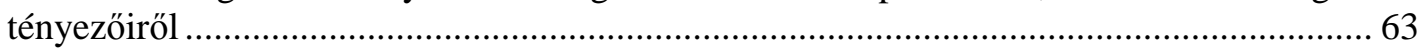

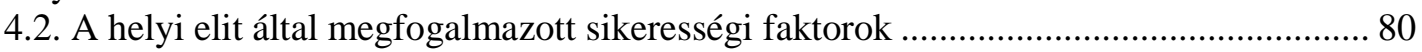

4.3. A vizsgálatba vont falvak honlapjainak fényképein található sikerességi tényezők ..... 97

5. Az aprófalvak kvantitatív és kvalitatív módszerekkel lehatárolt sikerességi tényezői, a sikeres aprófalu modellje............................................................................104

5.1. Dinamaikus aprófalvakat jellemző tényezők, a falvak fajlődési útjai .......................... 104

5.2. Az aprófalvak sikerességi modellje, különböző értékek szerint lehatárolt

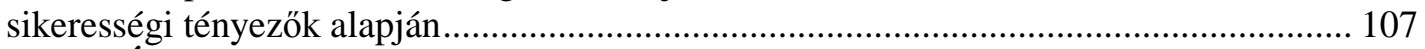

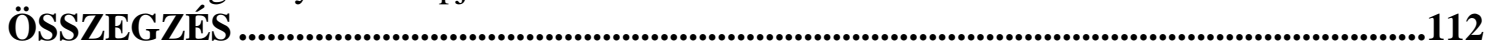

SUMMARY …................................................................................. Hiba! A könyvjelző nem létezik.

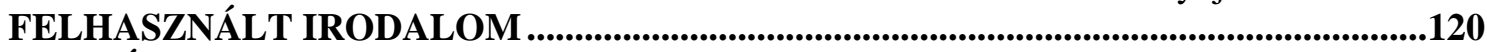

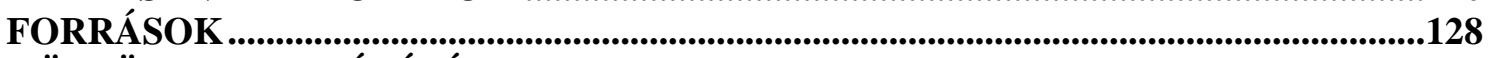

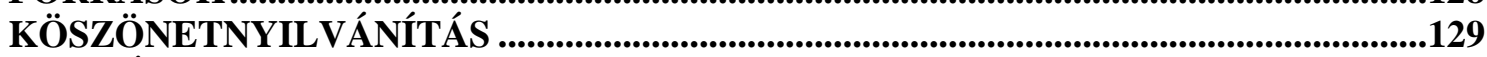

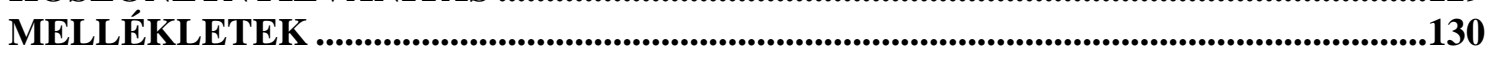

1. sz. melléklet: A vizsgálatba vont falvak kérdőíve................................................................ 130

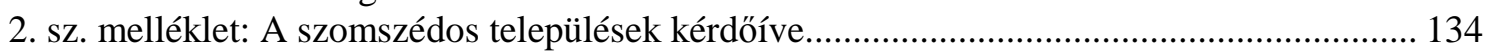

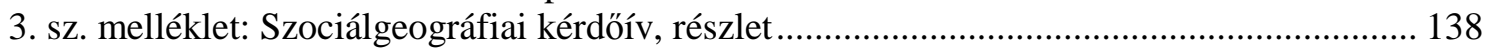

4. sz. melléklet: A vizsgálatba vont faluhoz füződő kötődés és nemzetiségi jellemzők ............ 139

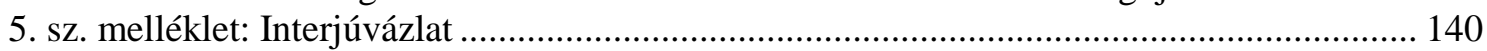

6. sz. melléklet: A fotódokumentáció tartalomelemzésének eredményei ................................ 142

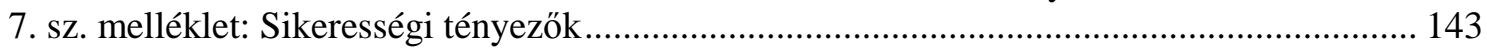

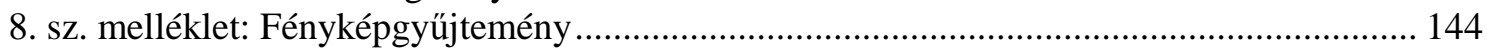

9. sz. melléklet: Az aprófalvak egységnormált fejlettségi értékei............................................ 152 


\section{ÁBRÁK ÉS KÉPEK JEGYZÉKE}

1. ábra. A vizsgálatba vont aprófalvak és szomszédos településeik országos elhelyezkedése

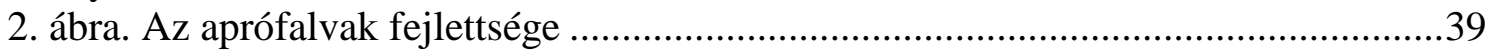

3. ábra. A falvak fejlettsége ..................................................................................48

4. ábra. Az aprófalvak és a teljes faluállomány fejlettségének alakulása a 2011-

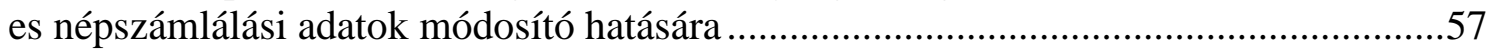

5. ábra. A legmagasabb és legalacsonyabb lakásépítési aránnyal rendelkező

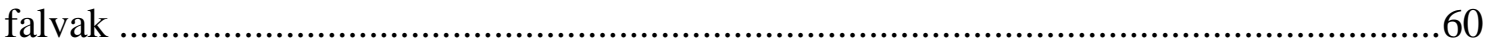

6. ábra. Dörgicse, Dunaszentmiklós és Hegymagas épületállományának

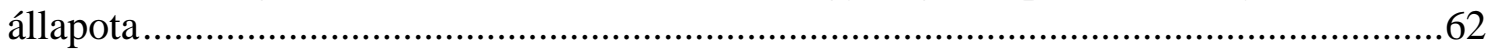

7. ábra. A vizsgálatba vont falvakban és a szomszédos településeken felvett értékelhető kérdőívek megoszlása

8. ábra. Apátistvánfalva és szomszédos településeinek lakossági véleménye a falu leginkább, és legkevésbé kedvelt tényezőit illetően

9. ábra. Apátistvánfalva és szomszédos településeinek véleménye az aprófalu nemzetiségi és turisztikai potenciáljáról

10. ábra. Apátistvánfalva és szomszédos településeinek véleménye a falu marketingtevékenységéröl, a polgármester és lakosság viszonyáról, a sikerességről és a jövőképről.

11. ábra. A nyugati határmente vizsgált települései által önmaguktól sikeresebbnek illetve sikertelenebbnek megnevezett falvak köre

12. ábra. A vizsgálatba vont aprófalvak körül $20 \mathrm{~km}$-es körzeten belül elhelyezkedő falvak fejlettsége.

13. ábra. Apátistvánfalva és szomszédos településeinek sikerről és jövőről alkotott véleménye

14. ábra. Az aprófalu sikerességéhez vezető út egy sikeres és egy fejletlen kistelepülés példáján

15. ábra. A versenyképességi piramismodell alapfeltételeinek módosulása a sikeres falu modelljének kidolgozása kapcsán

16. ábra. A falvak sikerességének piramis modellje.

17. ábra. Az Apátistvánfalván és szomszédos településein felvett kérdőívek a faluhoz való kötődéshez, turisztikai attrakciókhoz, hagyományápoláshoz és nemzetiségi megoszláshoz kötődő részletes lakossági válaszai ....

18. ábra. A terepen készített fényképeken fellelhető objektumok, köztük a sikerességi tényezők néhány manifesztációja.

1. kép. Néhány intézmény megnevezése a körjegyzőségi központ Alsómocsolád utcarészletének útbaigazító tábláján ......................................................144

2. kép. Szlovén felirat a határ menti, körjegyzőségi központ Apátistvánfalván.............144

3. kép. Csonkahegyhát - körjegyzőségi központ, több alapfokú intézménnyel.............145

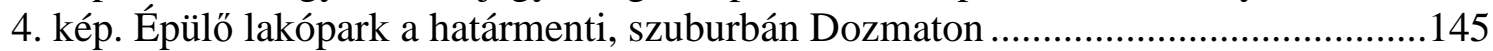

5. kép. XI. századi romtemplom a bortermelő Dörgicsén ............................................146

6. kép. Dunaszentmiklós II. világháborús német nemzetiségü áldozatainak emléktáblája

7. kép. A Fertő-Hanság Nemzeti Park világörökségi helyszínének, a horvát nemzetiségü Fertőhomoknak a helységnévtáblája.... 
8. kép. Az egyik legkevésbé sikeres aprófalu, Fony körjegyzőségi központjának székhelye

9. kép. A legkisebb lakosságszámú vizsgálatba vont település - Gosztola magas vendégéjszaka számot generáló hotele.....

10. kép. A bortermelő Hegymagas szőlői. A falu közösségi összefogása a település sikerességéhez nagyban hozzájárul

11. kép. A Szeged közeli Klárafalva meglehetősen magas tömegközlekedési

viszonylatszámot mutató buszmenetrendje

12. kép. A szuburbán Romonya újonnan épített lakóparkjának telekfelosztását mutató információs táblája.

13. kép. A jó ellátottsággal rendelkező Szántód a Balaton partján nem csak a hazai utazóközönséget célozza meg

14. kép. A Tisza-parti Tivadar tipikus part menti utcarészlete Beregben

15. kép. A határ menti Velemér Árpád kori temploma

16. kép. A német nemzetiségü Villánykövesd pincesora

\section{TÁBLÁZATOK JEGYZÉKE}

1. táblázat. A vizsgálatba vont települések mutatócsoportonkénti és összfejlettsége az aprófalvas településállományban

2. táblázat. Az összes falu, az 500 fó feletti települések és az aprófalvak mutatócsoportonkénti fejlettségi átlagai, valamint az átlagok helyezései

3. táblázat. A vizsgálatba vont települések mutatócsoportonkénti és összfejlettsége a teljes faluállományban

4. táblázat. A falvak és aprófalvak nemzetiségi mutató nélküli fejlettségi értékei, nemzetiségi arány függvényében

5. táblázat. A vizsgálatba vont falvak helyezésének változása az aprófalvak és a teljes faluállomány társadalom mutatócsoport és összfejlettségi értékei között a 2011-es népszámlálási adatok hatására.

6. táblázat. A vizsgálatba vont falvak épületállományának megoszlása a jó/új, rossz, átlagos állapot és üdülőfunkció szerint.

7. táblázat. Erdőhorváti, Komlóska, Háromhuta, Mogyoróska és Regéc lakosságának véleménye 14 környékbeli település szimpatikusságáról

8. táblázat. A területi autokorreláció értékei a vizsgálatba vont falvak összfejlettsége és környező falvaik összfejlettsége között

9. táblázat. A vizsgált településeken felvett interjúk megoszlása az egyes interjúalanyok között

10. táblázat. A vizsgálatba vont falvakban müködő honlapok képi anyagának sajátosságai a sikeresség szemszögéből.

11. táblázat. A kvantitatív és kvalitatív módszerek alapján lehatárolt sikerességi tényezők köre..... 


\section{BEVEZETÉS}

\section{A DOLGOZAT CÉLJA, KÉRDÉSEI, ALKALMAZOTT MÓDSZEREI, KUTATÁSI TERÜLET}

\subsection{A hazai aprófalvak vizsgálata során felmerülö problémák, a kutatás aktualitása, indokoltság}

A doktori disszertáció aktualitását az a több évtizede tartó folyamat adja, mely az aprófalvak népességének folyamatos emelkedésében jelentkezik. Ez a népességnövekedés nem azt jelenti azonban, hogy az egyes települések népessége nőne, hanem döntően azt, hogy az 500-1000 fös falvak népessége csökken, s így egyre több település kerül az 500 fónél nem népesebb aprófalvak kategóriájába ${ }^{1}$ (ENYEDI GY. 1980, Beluszky P. - Sikos T. T. 1982, Beluszky P. - Sikos T. T. 2007, Balogh A. 2008). Mindezzel a folyamattal az is párhuzamba állítható, hogy egyre több magyarországi járásra lesz jellemző az aprófalvak növekvő száma (BALOGH A. 2004).

További aktualitást ad a témának, hogy az urbanizáció sajátosságaként a koncentráció idején bekövetkező vidéki népességcsökkenés ellenére vannak olyan falvak (az 500 fő alatti népességgel rendelkezők között is), amelyek népességüket növelik. Vagyis a mellett, hogy egyre nő a népességvesztő területek nagysága, így az aprófalvak száma is, a falvak között vannak olyanok is, amelyek mindezen folyamatokkal ellentétesen, az utóbbi években növelni tudták a népességüket. Ez a falvak népességszám-változásában megfigyelhető folyamat döntően annak köszönhető, hogy a kistelepülések az utóbbi évtizedekben erőteljesen differenciálódtak, így köztük nem csak fejletlen, hanem kimondottan fejlett, sikeres aprófalvak is találhatók.

Azonban a differenciáltságot okozó, annak hátterében álló jelenségek nem, vagy csak részben ismertek. Ezért fontos a mi? - ki? - hogyan? kérdések vizsgálata az aprófalvak népességmegtartó erejének fokozása, fejlődési pályára állítása, és a sikerességüket okozó tényezők feltárása érdekében. Fontos tehát egyrészt azoknak a tényezőknek az ismerete, amelyek a népességcsökkenést mérsékelni tudják (mi? kérdésköre), másrészt azoknak a szereplöknek az ismerete, akik az aprófalvakat

\footnotetext{
${ }^{1}$ A KSH T-STAR adatai szerint 1960-ban 552, 2001-ben 1022500 fö alatti népességgel rendelkező települése volt Magyarországnak, ami azt jelenti, hogy az 1960 és 2001 közötti időszakban az aprófalvak száma megduplázódott. Az aprófalvak száma a 2011-es népszámlálási adatok alapján 1125, vagyis az aprófalvak a településállomány 1/3-át teszik ki.
} 
fejlődési pályára tudják állítani (ki? kérdésköre), harmadrészt a mód ismerete, ahogyan a fejlődés elérhető (hogyan? kérdésköre).

A fent említett problémakörök vizsgálata a disszertációban az elmúlt években fejlődést mutató, sikeres aprófalvak oldaláról történt. A vizsgálatba vont aprófalvak statisztikai elemzésekben és esettanulmányokban sikeres csoportokba sorolt aprófalvak közül kerültek kiválasztásra, úgy, hogy sikerességi tényezőik többfélék voltak. Itt szeretném hangsúlyozni, hogy ezeket a vizsgálatba vont falvakat nem én tartom sikeresnek, hanem a lent leírt tényezök mentén különböző szakirodalmak nevezték annak. Vagyis egyrészt tartózkodom attól, hogy a vizsgálat tárgyát képező aprófalvakat sikeresnek predesztináljam, másrészt nem az a célom, hogy sikerességük tényét igazoljam, vagy cáfoljam, hanem az, hogy megvizsgáljam sikerességi tényezőik aktualitását, vagy a sikerességi tényezőik érvényességének napjainkra bekövetkező megszünését.

A sikertényezők feltárása érdekében Magyarország tíz megyéjében zajlott a disszertációban ismertetett kutatás. Az előzőekben leírt módon az aprófalvak (1. ábra) kiválasztása a szakirodalomban - döntően statisztikai módszerekkel igazoltan - egy, vagy több tényező tekintetében fejlettnek, sikeresnek nevezett aprófalvak közül történt. A kiválasztás úgy zajlott, hogy a fejlődést, sikerességet eredményező tényezők minél szélesebb körben reprezentálva legyenek. Így tehát a kutatás tárgyát képező Alsómocsolád körjegyzőségi központ szerepkörének és ipari funkciójának, Apátistvánfalva szlovén nemzetiségének, körjegyzőségi központ szerepkörének és határ menti fekvésének következtében került fejlett települési csoportba, így a vizsgálatba is. Csonkahegyhát szintén körjegyzőségi központ, Dörgicse bortermelő község, épített öröksége turisztikai potenciált jelent a település számára. Dozmaton a határmenti és szuburbán jelleg, Dunaszentmiklóson a határmeni fekvés mellett a német nemzetiség, Fertőhomokon a határmenti fekvés mellett a horvát nemzetiség a települések fejlettségét nagymértékben befolyásoló tényező. A kutatás tárgyát képező települések közül Fony a Cserehát-Hernád-Bódva vidék környezeti adottságait tekintve kiemelkedő jelentőségü aprófalva, egyben körjegyzőségi központ. Gosztola fejlettségi rangsorban elért magas összpontszámának köszönhetően került a legsikeresebb falvak közé. Hegymagas esetében az erős közösség, Klárafalva esetében a közlekedési kapcsolatok voltak hangsúlyosak. Romonya vándorlási nyereségének és körjegyzőségi szerepkörének következtében került a fejlettebb települések közé a növekvő népességszámú községek között Baranya megyében. Szántód fejlettségét turisztikai 
potenciálján kívül számos egyéb tényező (ellátottság, szolgáltatások, közlekedés) adja. Tivadarban, az Észak-Alföld régió településén a turisztikai adottságok területfejlesztő hatása kiemelkedő. Velemért határmenti fekvése és épített öröksége, Villánykövesdet bortermelése és német nemzetisége emelte a korábbi vizsgálatokban a fejlett települések közé (HANusz Á. 2001, BAJMócy P. - BALOGH A. 2002, G. FeKETE É. 2004, BAJMócy P. - JózSA K. - Pócsi G. 2007, Beluszky P. - Sikos T. T. 2007, Balogh A. 2008). A kiválasztás során az előzőleg feldolgozott, és a későbbi fejezetben ismertetett szakirodalmakban leggyakrabban felsorolt sikerességi tényezők alapján történt meg a vizsgálatba vont falvak leválogatása.

A kiválasztás metodikája kapcsán további problémaként felmerülhet ugyan a kérdés, nem volt-e prekoncepció részemről a vizsgálatba vont települések kiválasztása, miszerint a korábbi vizsgálatokban egy, vagy több tényező kapcsán sikeresnek ítélt aprófalvak csoportjából kerültek ki a kutatásban részt vevő aprófalvak.

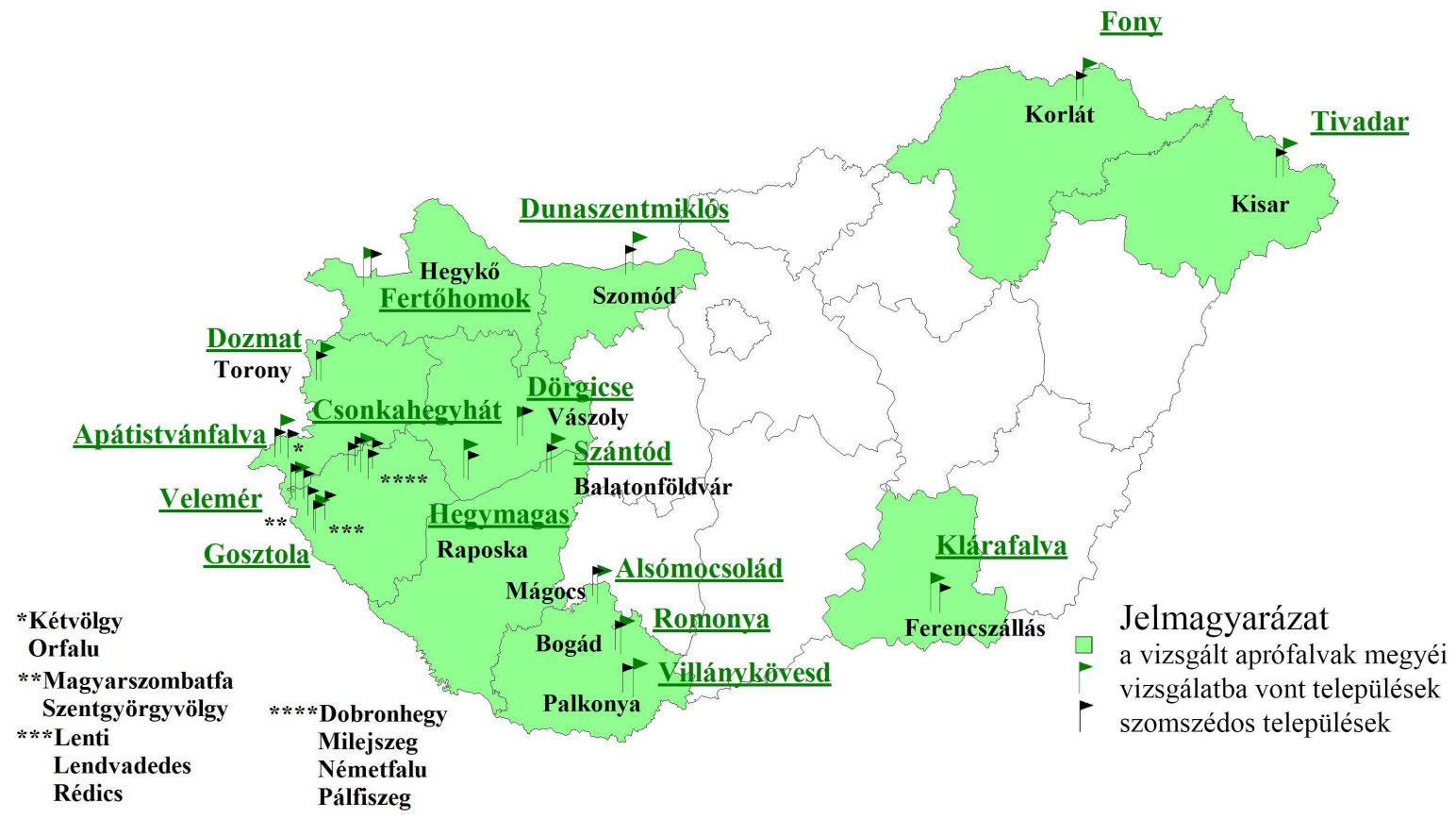

1. ábra. A vizsgálatba vont aprófalvak és szomszédos településeik országos elhelyezkedése

(Forrás: saját szerkesztés)

E kérdés kapcsán felmerülő aggályok kiküszöbölése véleményem szerint abban az esetben lehetséges, ha valamennyi magyarországi aprófaluban előzetes terepbejárást végzek, és a terepi tapasztalatokra alapozva határolom le a fejlett falvak körét. Mivel ennek teljesítése a kutatás költségeit nagymértékben megnövelte volna, és fizikai 
megvalósítása is nehézségekbe ütközött, így a korábbi kutatások tapasztalataira alapozva történt a lehatárolás. Fontos továbbá hangsúlyozni, hogy a vizsgálatba vont falvak nem teszik ki a szakirodalmi előzményekben megtalálható fejlettnek, sikeresnek nevezett falvak teljes körét, ellenben a lehető legszélesebb skálán mutatják be a következő fejezetben ismertetett, a szakirodalomban fellelhető sikerességi tényezőket.

Ahhoz, hogy a falukutatásokban megnevezett sikerességi tényezők helytállósága, avagy változása igazolható legyen, a vizsgálatba vont aprófalvakban többféle módszer alkalmazásával folytattam kutatást. Egyrészt lakossági kérdöívet vételeztem fel egyetemisták segítségével, másrészt lakossági kérdőívet készítettem a vizsgált aprófalvak közúton legközelebbi szomszéd településén (vagy településein), épületállomány felmérést végeztem, valamint polgármesteri interjúkat készítettem és egyéb, a helyi elithez tartozó lakosokkal interjúkat folytattam, a falvak honlapjain megtalálható fényképeken tartalomelemzést végeztem, fotódokumentációt készítettem² Elvégeztem továbbá a teljes faluállomány statisztikai vizsgálatát is, melynek eredményeit a későbbiekben szintén ismertetem.

A módszerek változatos alkalmazása egy, a falvak, aprófalvak kutatása során gyakran jelentkező problémát hivatott kiküszöbölni. Jelesül azt, hogy az eddigi kutatások vagy statisztikai módszerekkel főleg „kívülről” vizsgálták ezeket a kistelepüléseket, vagy kvalitatív módszerekkel ugyan, de csak egy-egy esettanulmánnyal. A disszertációban használt módszerek együttes alkalmazása, több település lakosságának és helyi elitje véleményének vizsgálata, és az aprófalvak fejlődését eredményező sikerességi tényezőinek lehatárolása adja a téma kutatásának újszerüségét.

\subsection{A kutatás kérdései, hipotézisei, céljai, a disszertáció logikai váza}

A hazai aprófalvas településállománnyal kapcsolatban a kutatás kezdetén a következő részkérdések merültek fel bennem:

\footnotetext{
2 A disszertáció további részében az alábbi fogalmakat következetesen a felsorolt településekre használom:

- vizsgálatba vont települések/vizsgálatba vont falvak/ vizsgálatba vont aprófalvak: Alsómocsolád, Apátistvánfalva, Csonkahegyhát, Dozmat, Dörgicse, Dunaszentmiklós, Fertőhomok, Fony, Gosztola, Hegymagas, Klárafalva, Romonya, Szántód, Tivadar, Velemér, Villánykövesd.

- szomszédos települések: Balatonföldvár, Bogád, Dobronhegy, Ferencszállás, Hegykő, Kétvölgy, Kisar, Korlát, Lendvadedes, Lenti, Magyarszombatfa, Mágocs, Milejszeg, Németfalu, Orfalu, Palkonya, Pálfiszeg, Raposka, Rédics, Torony, Szentgyörgyvölgy, Szomód, Vászoly.
} 
- A vizsgálatba vont aprófalvak sikerességét eredményező tényezők ma is fejlődést elődiző faktorok-e?

- A statisztikailag fejlett aprófalvak a teljes faluállományon belül is magas összfejlettségi értékekkel rendelkeznek-e?

- A döntően statisztikai adatokon nyugvó falutipizálások kapcsán sikeresnek ítélt falvak fejlettségét okozó indikátorok és a helyi lakosok által megfogalmazott sikerességi tényezők mennyiben azonosak?

- Rendelkeznek-e információkkal a szomszédos települések lakosai a kutatott faluról?

- A vizsgálatba vont falvak utcaképe, házai mennyiben hasonlítanak egy átlagos aprófalu utcaképéhez, tapasztalható-e e tekintetben különbség?

- A statisztikai adatelemzés, kérdőívezés, interjúk, épületállomány felmérés, a falvak honlapjainak fotódokumentáció elemzése segítségével az aprófalvak mely sikerességi tényezői határolhatók le?

- Miként határolható le a sikeres aprófalvak fejlődését előidéző tényezők csoportja és hogyan modellezhetö egy sikeres aprófalu?

A részkérdéseket 3 fö kérdésbe vontam össze, melyek a következők:

- Mely tényezők eredményezik az aprófalvak sikerességét?

- Milyen módszerekkel határolható le a sikerességi tényezők köre?

- Modellezhetö-e, ha igen, hogyan a sikeres aprófalu?

Hipotéziseim szerint:

- a lakosság, a helyi elit véleménye, és a statisztikai sikertényezők köre nem azonos,

- a kérdőíves adatfelvétel, az interjúk, a statisztikai adatok, az épületállomány felmérés és a fotódokumentáció elemzése egymást kiegészítve és együttesen jelölik ki a sikerességi elemek körét,

- a sikerességi tényezők kvantitatív és kvalitatív módszerekkel történő feltárásával a sikeres aprófalut eredményező tényezők csoportja megadható, és a sikeres aprófalu modellezhető.

\section{A kutatás célja többes:}

- a fejlett aprófalvak ,sikertényezőinek” lehatárolása, a sikeres falu modellezése,

- a sikeresség vizsgálati lehetőségeinek bemutatása,

- valamint részcél a kutatási eredmények szemléletes módon történő közlése. 
A fent leírtak alapján a disszertáció logikai váza az alábbi elemekre osztható. A hazai faluállomány társadalom- és gazdaságföldrajzi jellemzőit ismertető, és a sikeresség fogalomkörét használó hazai és nemzetközi szakirodalmak áttekintését követően kiválasztottam a vizsgálatba vont aprófalvakat, melyek sikerességi vizsgálatának első lépéseként elvégeztem az aprófalvak statisztikai vizsgálatát. A statisztikai adatok elemzése arra szolgált, hogy a kiválasztott aprófalvakról felállított rangsor alpján megnevezhetők legyenek a statisztikai sikeresség tényezői.

Második lépésként elvégeztem a teljes faluállomány statisztikai vizsgálatát, annak érdekében, hogy a kiválasztott aprófalvakról eldönthető legyen, hogy csak az aprófalvak között szerepelnek-e a legjobb helyeken, vagy a teljes faluállományt tekintve is a jók között foglalnak helyet? Ilyen típusú vizsgálatra eddig a hazai aprófalvas vizsgálatokban nem került sor.

Harmadik lépésként a kiválasztott aprófalvakban végeztem empirikus kutatást a következő fejezetben leírt módszerek (kérdőíves adatfelvétel, interjú, épületállomány felmérés, fotódokumentáció elemzés) segítségével, a „kívülről” megadható statisztikai sikerességi tényezők és a „,belülről” mérhető sikerességi tényezők közötti egyezőség és különbözőség kimutatására.

Mivel a fenti empirikus módszerek lakossági kérdőívéből kiderült, hogy a vizsgálatba vont települések környékről alkotott véleménye a hozzájuk meglehetősen közel eső falvakra (nem csak aprófalvakra) vonatkozik, ezért az empirikus kutatás köztes lépéseként a vizsgálatba vont települések környékének statisztikai vizsgálatát is elvégeztem. Ez a statisztikai vizsgálat területi autokorreláció számítással annak eldöntésére irányult, hogy a vizsgálatba vont települések fejlettsége és a környékbeli falvak fejlettsége között van-e sztochasztikus kapcsolat. Szintén köztes lépést jelentett az egyik észak-magyarországi mintaterület - Fony - és környező falvainak szociálgeográfiai vizsgálata.

A kutatás utolsó lépése a 2013 nyarán elérhetővé vált 2011-es népszámlálás adatainak tükrében a disszertáció adatainak aktualizálása, a népszámlálási adatok módosító hatásának ismertetése volt.

A fent megnevezett módszerekkel tehát a szakirodalmi előzmények feldolgozásával a falvakra ható településpolitikai döntéseket tekintem át vázlatosan a disszertációban az 1950-es évektől napjainkig, miközben szót ejtek a differenciálódott aprófalvakról, azok csoportosításáról és a depresszív térségek jellemvonásairól. Bemutatom a települések sikerességi tényezőit, hangsúlyozva a tényezők körében 
bekövetkezett változásokat. Statisztikai és empirikus kutatási módszerekkel határolom le az aprófalvak sikerességi tényezőit. Törekszem arra, hogy a statisztikai módszerekkel lehatárolható sikerességi tényezők körét összevessem az empirikus kutatásaim eredményeivel, ily módon a kemény és puha módszerek kombinációját alkalmazom. Mindezek alapján modellt alkotok a falvak sikerességére vonatkozóan. A disszertációban a sikerességet versenyszemléletü megközelítésben „kívülröl” és a társadalmi értékeket előtérbe helyezve „belülröl” is kutatom.

\subsection{A disszertációban alkalmazott kutatási módszertan}

Mivel a téma feldolgozása során több módszer együttes alkalmazására került sor, így fontosnak tartom egy különálló módszertani összefoglaló ismertetését, mely az alábbiakban foglalható össze. A települési siker, fejlődés és versenyképesség fogalmainak tisztázásához, tényezőinek feltárásához a szakirodalmi feldolgozás során számos hazai és nemzetközi irodalmat tekintettem át a vizsgálatba vont települések körének lehatárolása, a fogalmi keretek meghatározása, az aprófalvak időben változó sikerességi tényezőinek felmérése, valamint a falvakra alkalmazható sikermodell alapjainak felállítása érdekében.

Kutatásom kvantitatív módszereként, a sikerességi tényezők „kívülről” történő szemléletü lehatárolásához statisztikai másodelemzést végeztem, valamint nagyszámú elsődleges statisztikai adatot állítottam elő. A hazai faluállomány fejlettségének, sikerességének megállapításához - az adatok leválogatásához - az alábbi adatbázisokat, programokat, elérhetőségeket használtam:

— KSH, 2001-es évi népszámlálás (népmozgalmi adatok, [12])

— KSH, 2011-es évi népszámlálás (népmozgalmi adatok, [12])

— KSH TEIR (gazdasági, intézményi, idegenforgalmi, infrastrukturális mutatók, [12])

— Magyarország autóatlasza, 6. kiadás, 2004 (idegenforgalmi vonzerő mutatói, [13])

— Szőlőültetvények Magyarországon, 2001 (borvidékek mutatója, [21])

— Magyarország pálinkatérképe, 2009 (pálinkavidékek mutatója, [14])

— www.nonprofit.hu (civil szervezetek mutatója, [18])

— www.menetrendek.hu (tömegközlekedési járatszám mutató, [17]) 
— www.mav-start.hu (tömegközlekedési járatszám mutató, [16])

— www.maps.google.com (kistérségi központ, megyeszékhely út- és időtávolságának mutatója, [15]).

A felhasznált adatbázisok egy részének adatai egyszerü legyüjtéssel elérhetők voltak, pl. KSH népszámlálási adatai, TEIR adatok. Más adatokat viszont valamennyi vizsgált falura (összesen 2934) egyenként kellett előállítani. Így például a tömegközlekedési járatszám mutatókat, a kistérségi központ, megyeszékhely út- és időtávolságának adatait, vagy a müködő civil szervezetek számát csak manuálisan, településekenkénti lekérdezés útján lehetett előállítani. Ez megnövelte ugyan a kutatás időtartamát, de számos más forrásból nem elérhető, elsődleges adatot szolgáltatott a statisztikai elemzéshez.

A statisztikai adatelemzést - vagyis 27 lent megnevezett mutató vizsgálatát először az 1990-ben, 2001-ben vagy 2010-ben az aprófalvak kategóriájába tartozó 1072 településen végeztem el (9. sz. melléklet). Vagyis aprófalvaknak azokat a településeket tekintettem, amelyek az 1990-es, 2001-es és 2010-es évek valamelyikében 500 fö alatti lakosságszámmal rendelkeztek ${ }^{3}$. Az, hogy a vizsgálatba vont települések legalább az egyik időpontban az aprófalvak kategóriájába tartozzanak, arra adott lehetőséget, hogy a kutatás során a népességszámot veszítő, a stagnáló és az elmúlt években az aprófalvak kategórájából kinőtt falvak külön csoportokban is értelmezhetőek legyenek. A vizsgálat során lehatároltam azoknak az aprófalvaknak a körét, amelyek a rendelkezésre álló, illetve az általam előállított elsődleges statisztikai adatok alapján a legmagasabb pontszámmal rendelkeznek, amelyek a legfejlettebbek az aprófalvak között. A statisztikai vizsgálat tehát egy kívülről szemlélődő, települési fejlődést eredményező tényezőcsoport lehatárolására szolgált.

Annak érdekében, hogy a vizsgálatba vont településekről eldönthető legyen, vajon az aprófalvak között napjainkban is a legfejlettebb falvak között vannak-e, a 27 továbbiakban ismertetett mutatót 6 mutatócsoportba rendeztem. A mutatók e mutatócsoportokban „korrelálnak” leginkább (a mutatócsoportok mutatói között így is csak gyenge sztochasztikus kapcsolat áll fenn). Az épített lakások aránya mutató egyik mutatócsoportba sem illeszthető, így ez önkényesen került besorolásra a népesség mutatócsoportba. A 27 mutató értékeit 1 és 100 közé eső intervallumba soroltam

\footnotetext{
${ }^{3}$ Az aprófalvak két sajátos helyzetủ csoportjának jellmezői, vagyis azon települések, amelyek „belefogytak” és azok, amelyek „kinőttek” az aprófalvak kategóriájából 2010-re, a későbbiekben kerülnek bemutatásra.
} 
(egységnormáltam), oly módon, hogy az egyes mutatók értékeinek megoszlása megfelelt az egységnormálás után kapott mutatónkénti megoszlásnak. A legmagasabb értékkel rendelkező falu 100, a legkisebb értékkel rendelkező falu 0 pontot kapott. A mutatók jellegéből (nem a legmagasabb érték a legjobb) adódóan a népesség mutatócsoport halálozási ráta értékeinél, a gazdaság mutatócsoport álláskeresők és szociális segélyben részesítettek értékeinél, valamint a közlekedés mutatócsoport megyeszékhely és kistérségi központ távolság értékeinél a fordított egységnormálás képletét alkalmaztam. Számításaimat tehát az alábbi képletek alapján végeztem:

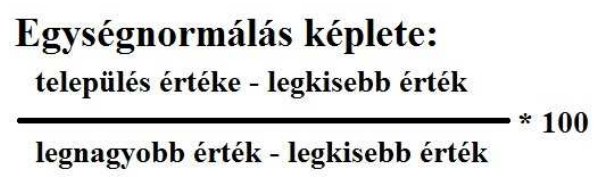

\author{
Egységnormálás fordított képlete: \\ település értéke- legnagyobb érték \\ legkisebb érték - legnagyobb érték
}

A vizsgálatba vont mutatók között szerepeltek népmozgalmi adatok, a lakásépítésre, civil szervezetekre, nemzetiségi hovatartozásra, iskolai végzettségre vonatkozó mutatók. Számoltam továbbá a településeket jellemző ivóvízhálózat, csatornahálózat, gázellátottság értékeivel, internet eléréssel, kiskereskedelmi és alapfokú intézményi ellátottsággal. Fontosnak tartottam továbbá a gazdasági értékek közül az álláskeresők, adóalap, vállalkozások és szociális segélyezettek vizsgálatát, a kistérségi központ és megyeszékhely elérhetőségi viszonyainak feltárását, valamint számos idegenforgalmi mutató bevonását is. Ezek alapján az aprófalvak (és később a teljes faluállomány) vizsgálatánál az alábbi mutatók értékeivel számoltam:

Népesség

- Születési ráta (évente, \%o), 2001-2010 között

- Halálozási ráta (évente, \%o), 2001-2010 között

- Vándorlási különbözet (évente, \%o), 2001-2010 között

- Népességszám-változás (évente, \%o), 2001-2010 között

- Épített lakások aránya (évente, \%o), 2001-2010 között

Társadalom ${ }^{4}$

- 1000 före jutó (müködő) civil szervezetek aránya, 2010

- 1000 főre jutó anyaországgal rendelkező nemzetiségi lakosság aránya, 2001

- 18-X éves legalább középiskolai érettségivel rendelkezők aránya a megfelelő korúak százalékában, 2001

- 25-X éves egyetemi, főiskolai oklevéllel rendelkezők aránya a megfelelő korúak százalékában, 2001

\footnotetext{
${ }^{4}$ Mivel a dolgozat benyújtása előtt a 2011-es népszámlálás adatai elérhetővé váltak a KSH oldalain, ezért a 2001-es népszámlálás adatait használó társadalom mutatócsoport értékeit, és ezzel egyidejủleg az összfejlettségi értékeket újraszámoltam, mely vizsgálat eredményeiről a későbbiek során említést teszek.
} 
Ellátottság

- 100 főre jutó közüzemi ivóvízvezeték-hálózatba bekapcsolt lakások aránya, 2010

- 100 före jutó közcsatorna-hálózatba bekapcsolt lakások aránya, 2010

- 100 före jutó háztartási gázfogyasztók aránya, 2010

- 100 főre jutó internet előfizetések aránya, 2010

- 100 före jutó kiskereskedelmi üzletek (humán gyógyszertárak nélküli) aránya, 2006

- alapfokú intézményi ellátottság ${ }^{5}, 2010$

Gazdaság

- Nyilvántartott álláskeresők aránya a munkaképes korú népességből, 2010

- 1 főre jutó összevont adóalap, 2010

- 100 főre jutó regisztrált egyéni vállalkozások aránya, 2010

- 1000 före jutó rendszeres szociális segélyben és rendelkezésre állási támogatásban részesítettek aránya, 2010

Közlekedés

- Megyeszékhely távolsága időben (közúton, személygépkocsival), 2010

- Kistérségi központ távolsága kilométerben, 2010

- Kistérségi központba induló tömegközlekedési járatszám (busz, vonat, HÉV) egy átlagos munkanapon, maximum egy átszállással, 2010

- 100 före jutó személygépkocsik aránya, 2010

Idegenforgalom

- 1000 före jutó vendéglátóhelyek aránya, $2006^{6}$

- 100 före jutó kereskedelmi szálláshelyeken és magán szállásadásban töltött vendégéjszaka, 2006

- 100 före jutó kulturális rendezvényen résztvevők aránya, 2006

- idegenforgalmi adottság $^{7}$ (vonzerö), 2010

Az összesen hat mutatócsoportba - népesség, társadalom, ellátottság, gazdaság, közlekedés és idegenforgalom - sorolt 27 mutató tisztított, egységnormált értékeit mutatócsoportonként összeadva állapítottam meg az aprófalvak mutatócsoportonkénti, majd összfejlettségi rangsorát. Ez a csoportba sorolás lehetőséget kínált az egyes tényezők elemzésére, a sikerességi faktorok feltárására. Ezt követően a vizsgálatot kiterjesztettem a hazai falvak egészére. A vizsgálat kiterjesztése a teljes hazai faluállomány 2934 településére ${ }^{8}$ azért is volt fontos, mert az aprófalvak összességének

\footnotetext{
${ }^{5}$ Posta, jegyzőség, körjegyzőség, benzinkút, bank, háziorvos, gyógyszertár, iskola, óvoda, könyvtár léte/nem léte (1pont/0pont) adták az alapfokú intézményi ellátottság értékét.

${ }^{6}$ Négy mutató esetében a 2006-os év adatait vettem figyelembe, mivel a rendelkezésre álló 2010-es adatok hiányos volta nagyban torzította volna a mutatócsoportok egységnormált értékeit (a 2006-os időszakra vonatkozóan jóval kevesebb adathiátust találtam).

${ }^{7}$ Vízközelség (1 pont), épített örökség (1 pont), hegyvidék (1 pont), borvidék (1 pont), pálinkavidék (1 pont), világörökség (3 pont), Balaton-part (3 pont), Balaton $10 \mathrm{~km}$-es közelsége (1 pont), Velencei tó partja (2 pont), Velencei tó $10 \mathrm{~km}$-es közelsége (1 pont), Tisza tó partja ( 2 pont), Tisza tó $10 \mathrm{~km}$-es közelsége (1 pont), Fertő tó partja ( 2 pont), Fertő tó $10 \mathrm{~km}$-es közelsége (1 pont), nemzeti park (1 pont), egyéb - sziklaforrás, kaptárkő stb. (1 pont) adták a vonzerö összesített értékét.

8 Vizsgálatom faluállományát azok a települések adják, amelyek nem tartoznak a Beluszky Pál által felállított városhierarchia rendszerébe (BELUSZKY P. - GYÖRI R. 2006).
} 
a teljes faluállományon belüli statisztikai helyzetére vonatkozó vizsgálatra, vagyis az aprófalvak fejlettségi helyzetének statisztikai mutatókkal mért faluállományon belüli vizsgálatára eddig az aprófalvas kutatásokban nem került sor.

A kutatás során a lakosság véleményének feltárásához kérdőíveket használtam (1. sz. melléklet, 2. sz. melléklet). Ennek a módszernek az alkalmazásával a „kívülröl” nyerhető információk mellett „,belülről” nyerhető információkkal és adattartalommal vált bővíthetővé a sikerességi tényezők köre. Ez azért is fontos, mivel a hazai aprófalvas településállomány elsősorban statisztikai oldalról kutatott terület, az azonban, hogy e kistelepülések lakossága hogyan vélekedik falujáról, hol helyezi el azt a környező települések között, miként értékeli faluja helyzetét, mennyire ismert számára a településében rejlő potenciál, mely tényezők meglétét tartja fontosnak a település fejlődése szempontjából, csupán egy-egy esettanulmányból ismert.

Fontos hangsúlyozni, hogy az empirikus kutatás során megkérdezett lakosokhoz intézett kérdések nem arra vonatkoztak, hogy az általam statisztikailag fejlettnek nevezett falvakban mik a siker tényezői a lakosok szerint. Hiszen ez két eltérő értékrendszer mentén mért siker, sikeresség lenne. A lakossági kérdőívezés módszere arra kínált lehetőséget, hogy egy másfajta értékrendszer mentén is lehatárolhatók legyenek a sikerességi tényezők, és a különböző értékek mentén való vizsgálódás eredményei közötti egyezőségek és különbözőségek is megadhatók legyenek.

Ez utóbbi típusú, a társadalom oldaláról vizsgálódó közösségkutatások a XX. század elején a társtudományok - antropológia, néprajz, szociológia - művelői körében kerültek elötérbe. A hazai és a nyugati közösségtanulmányok tekintetében azonban eltérés mutatkozik. Az úgynevezett „community studies”, vagyis a nyugati közösségtanulmányok előszeretettel használták az antropológia módszereit és fogalomtárát, a nyugati szociológusok elsősorban városszociológiai vizsgálatokat végeztek. Figyelmük azért is fordult a városszociológiai vizsgálatok felé, mivel a modern város kialakulásával a feudális városok szigorú belső térbeli rendje (etnikai, vallási, foglalkozási, vagyoni stb.) megszünt (WeBER, M. 2000). A szociálökológia képviselői ugyanakkor úgy gondolták, hogy a városokban a látszólagos káosz ellenére valamiféle szabályszerüség uralkodik. A várost ők olyan térkategóriának tekintették, ahol a lakosok között szoros a kölcsönhatás, kutatóik alapvetően a megfigyelés módszerére alapoztak (BURGES, E. W. 1929, HoYT, H. 1939, HARRIS, C. D. -UlMANN, E. L. 1945). A közösségtanulmányokban a nyugati kutatók első nemzedéke a vidékiességet hangsúlyozta, majd a kritikai szemlélet jelent meg vizsgálataikban, az 
1970-es évektől pedig módszertani újítások jelentkeztek, mint pl. a kapcsolatháló elemzés, vagy mentális térképezés (KovÁCs É. 2007).

A kelet-európai vizsgálatokban, így Magyarországon is a közösségtanulmány összefonódott a falukutatással, mondván kisebb területi egység esetén van igazán lehetőség a közösség behatóbb vizsgálatára (SÁRKÁNY M. 2000). Az első hazai falukutatások csehszlovákiai fiatalok falujárásával kezdődtek, mely falujárások az 1930as évekre falukutató mozgalommá nőtték ki magukat. A mozgalom célja a falu problematikájának feltárása volt, abból az alapvető feltevésből kiindulva, mely szerint a faluban minden társadalmi probléma megtalálható és nyomon követhető. A falukutatás az 1960-as években a néprajzkutatók figyelmének központjába került, újabb lendületként pedig az 1970-es évektől egyfajta „szakosodás” volt megfigyelhető a kutatásokban - ekkor alakult ki pl. a településszociológia is. Erre az időszakra a falu már nem sürítette magába a társadalom minden problémáját (KоTICs J. 2007). Az 1990-es évektől a közösségtanulmány fogalomköre a vidékfejlesztéssel kapcsolódott össze. Napjaink kutatásai pedig arról számolnak be, hogy bár a vidéki térségek jelentős része ma is küzd a szegénységgel, munkahelyhiánnyal, a nem elégséges intézményi és infrastrukturális ellátottsággal, a közösségek elsorvadásával, mégis köztük kimondottan jó helyzetben lévő településeket is találunk (BELUSZKY P. - SiKOS T. T. 2007, BALOGH A. 2008).

Mindezek miatt fontos a lakosság véleményének megismerése is, hiszen a siker egyes tényezői megadhatók statisztikai adatokkal, mások viszont vélhetően nem. Mérhető statisztikai adatokkal a településeken az iskolázottság, a vállalkozási hajlandóság, a gazdasági mutatók, a jövedelmi mutatók változása, a közlekedési, idegenforgalmi helyzet, stb. De vélhetően a sikeres település számos olyan tényezővel is rendelkezik, melyekről a statisztika nem tud, vagy csak részben tud adatokat szolgáltatni. A kulturális hagyományok megőrzése, a tradíciók, értékek közötti egyensúly megteremtése, az önkormányzati és lakossági aktivitás nem mérhető statisztikai adatokkal ${ }^{9}$. A statisztikai adatok és empíria együttes alkalmazására egy település sikerességének vizsgálatánál az MTA RKK ATI Alföld II. Program keretén

\footnotetext{
${ }^{9}$ Például Solymár településen az 1990-es években építményadó került bevezetésre (VÁRADI M. M. 1997). $\mathrm{Az}$ adó bevezetésének oka, hogy a településen lévő lakóházak száma (1961db) közel annyi, mint az üdülőházaké (1356 db). Az üdülőházak tulajdonosai nem voltak állandó lakosai a településnek, így a község elesett számos állami támogatástól. Az állandó lakosoknak az építményadó csupán 10\%-át kellet fizetnie, míg az üdülőházakban lakó, nem állandó lakosoknak a teljes összeget. Ezzel ösztönözte az önkormányzat a faluban élőket a bejelentkezésre, így elérvén azt, hogy az állandó lakosságszám után fizetett állami normatíva, és a személyi jövedelemadó növelje az önkormányzat bevételeit, mely bevételek összetételét a statisztikai adatok értelemszerüen nem tartalmazzák.
} 
belül a „Sikeres, megújulóképes városok és falvak az Alföldön” altémában öt sikeresnek ítélt alföldi város kapcsán már láthattunk példát (TiMÁr J. - VELKEY G. 2003). Dolgozatomban én is a statisztikai elemzés és empíria együttes alkalmazására törekszem a sikeresség faktorainak feltárása érdekében. Úgy vélem, a statisztikailag kimutatható sikerességi faktorok mellett a helyi társadalom véleménye további, a statisztikai adatelemzés által nem lehatárolt faktorok fontosságára is felhívja a figyelmet. A kérdőívezés során törekedtem arra, hogy a lakosság véleményét ne az „Ön szerint siker-e az, hogy (...)?" típusú kérdésekkel mérjem fel. Vagyis nem a statisztikai adatelemzés által lehatárolt faktorok meglétére, illetve azok minőségére kérdeztem rá, hanem a statisztikai eredményektől függetlenül érdeklődtem a lakosság sikerről, sikerességről alkotott fogalmairól, az általuk fontosnak tartott sikerességi tényezők felöl.

A kérdőívek felvételezése egyrészt a vizsgálatba vont falvakban történt, másrészt azok szomszédos településén (településein). Több szomszédos települést a vizsgálatba vont falvak körjegyzőségi központ volta és a szomszédos település kis mérete esetén vontam be a kutatásba. A vizsgálatba vont falvakban egy 29 kérdésből álló kérdőívet alkalmaztam, mely kérdései a következő főbb kérdéscsoportokhoz kapcsolódtak:

1. mennyire kötődik a megkérdezett lakos a falujához?

2. van-e turisztikai vonzerő (természeti, épített) a településen?

3. él-e valamilyen kisebbség a faluban?

4. hol helyezi el a lakos a faluját sikeresség tekintetében a környező települések között, milyen a falu marketingtevékenysége?

5. milyen a lakosság és a polgármester kapcsolata?

6. milyen sikerességi tényezőket nevez meg a lakosság, milyennek látja a vizsgálatba vont falu jövőjét?

A szomszédos településeken szintén lakossági kérdőíveket vettem fel, melyekben a vizsgálatba vont falvakra vonatkozóan tettem fel kérdéseket (összesen 25-öt) a fenti kérdéscsoportok köré szerveződve. Ezekre a kérdésekre adott válaszok a szomszédos település lakosságának véleményét tükrözik, és a vizsgálatba vont falura vonatkoznak. A vizsgált településeken 276 kérdőívet, a szomszédos településeken 212 értékelhető kérdőívet vételeztem fel fel egyetemisták segítségével. A vizsgálatot megelőzően 
Remeteszőlősön és szomszédos településén, Nagykovácsiban próbakérdőívezést végeztem. A próbakérdőívezésnek több célja volt. Egyrészt szerettem volna megtudni, mennyire érhetőek a kérdőívek kérdései a lakosság számára, másrészt a kutatás ütemezése érdekében szükségem volt egy-egy kérdőív átlagos lekérdezési idejére, valamint a tartalmi és formai hibákat is javítani akartam, a kérdőívezés mószertanát követve (BABBIE, E. 2003). A próbakérdőívezés során kisebb formai hibákat tapasztaltam, valamint világossá vált számomra, hogy a szomszédos településeken a lekérdezési idő némileg hosszabb, mint az előzetesen tervezett, ugyanis az ott élők szinte minden esetben igényelték a kutatás rövid ismertetését, érdeklődtek arról, hogy miért nem saját településükről, hanem a vizsgálatba vont faluról kérdezem őket. A tartalmi elemek között is szükség volt egy kérdés javítására. Utolsó, jövedelmi viszonyokra vonatkozó kérdésemnél azt tapasztaltam, hogy a próbakérdőív során meghatározott öt jövedelmi kategória nem elégséges, hiszen rendre a legmagasabb kategória került bejelölésre, melynek nem volt felső határa. Így a jövedelmi kategóriákat a későbbiekben másik két magasabb kategóriával bővítettem. A jövedelmi viszonyok ismertetése azonban nem része a dolgozatnak, csakúgy, mint a megkérdezettek korára és iskolai végzettségére vonatkozó adatok ismertetése sem. Kis lélekszámú települések révén a megkérdezettek valószínűsíthetően úgy érezték, hogy a fenti kérdésekre adott válaszaik alapján könnyen azonosíthatóakká válnak, így a fenti kérdésekre a próbakérdőívezést követően, csak igen kevés értékelhető választ kaptam. A kis elemszám miatt e kérdésekre adott válaszok nem értékelhetők.

A lakossági kérdőívezés eredményeiböl világossá vált, hogy a vizsgálatba vont falvak lakosai a sikerességük megítélése szempontjából a környező falvakban (szük környékben és nem csak aprófalvakban) gondolkodnak. Így kutatásomnak az is részét képezte, hogy a 16 vizsgálatba vont falu közvetlen környezetében elhelyezkedő falvak fejlettsége és a vizsgált falvak fejlettsége milyen hasonlóságot, vagy különbséget mutat. Vagyis a vizsgálatba vont falvak 20 km-es - közúton megközelíthető - térségében elhelyezkedő 310 falu statisztikai adatait külön is vizsgáltam, a vizsgálatba vont települések és a környékbeli falvak közötti fejlettségbeli kapcsolatot területi autokorrelácival elemeztem. Mikroszinten is történt elemzés, az egyik vizsgálatba vont falu (Fony) 2013-as szociálgeográfiai felmérésének (144 kérdőív) környező településekre vonatkozó szimpatikussági válaszait szintén elemeztem dolgozatomban.

A helyi elit - elsősorban a kistelepülési polgármesterek - véleményének megismerése érdekében a szociológia, a közvélemény-kutatás és a geográfia egyik 
leggyakrabban alkalmazott módszerét, az interjút is felhasználtam adatgyüjtési módszerként ${ }^{10}$. A kutatás kezdetén személyes interjúk készítését terveztem, elöre rögzített forma alapján - mivel az interjúalanyok időben és térben távol voltak egymástól, így az elérhetőségi viszonyok miatt a könnyebben tervezhető és koordinálható személyes interjú tünt alkalmasnak (FALUS I. 2001). Ezt a formát azonban már az első interjú (próbainterjú - Remeteszőlős) során felületesnek találtam, így annak érdekében, hogy a kistelepülési sikeresség problémakörrel kapcsolatban minél több témát érinteni tudjak, végül a személyes interjú egy sajátos formájának, a mélyinterjúnak a készítése mellett döntöttem, félig strukturált formai kötöttség szerint (Földes A. 1999, BABbie, E. 2003, Majoros P. 2004). Ily módon szabad, kötetlen beszélgetésre nyílt lehetőségem az interjúalannyal, úgy, hogy közben valamennyi korábban felvázolt kérdéskört érinteni tudtam. Az interjúk közül néhányat írásbeli kikérdezés útján végeztem, mivel a kérdöíves adatfelvételhez kötött interjúzás időpontja nem minden interjúalany számára volt megfelelő. Továbbá interjúalanyaim közül néhányan csak úgy vállalták az interjút, ha előre megadott kédésekre írásban válaszolhattak. Ez felveti azt a problémát, hogy az interjúk lekérdezésének módszertana nem egységes, mivel azonban az íly módon felvett interjúkból is származott a kutatás szempontjából lényeges adat, a kutatásmódszertan egységességének rovására is a dolgozatban maradtak az interjúk eredményei. Problémát jelentett továbbá, hogy többszöri megkeresésre is volt olyan interjúalany, aki elzárkózott az interjúadástól. Egy esetben, Fony településen, szóbeli csoportos interjút - fókuszcsoportos interjút készítettem. Az interjúk során érintett témák a következő föbb kérdéscsoportok köré szervezödtek:

1. a polgármester személye ${ }^{11}$

2. konfliktusok a településen

3. a falvak lakosainak fö megélhetési forrása, foglalkoztatók

4. pályázati tevékenység

5. lakossági aktivitás, intézményi, infrastrukturális ellátottság

6. turisztikai vonzerő a településen

${ }^{10}$ Minden egyes interjú anyagfelvételét megelőzte a felkészülés, időpont egyeztetés, megismerkedés fázisa. Spontán interjú nem készült. Az interjúk felvételénél figyeltem arra, hogy a 2010-es önkormányzati választás előtt és után is készüljenek interjúk, így a kutatás 2009-2013-as intervallumban zajlott.

${ }^{11}$ Egyéb, a helyi elithez tartozó megkérdezetteknél ez a kérdéskör értelemszerüen nem szerepelt. 
7. a falu megítélése a sikeresség szempontjából a környező településekkel összevetve

8. jövőkép, sikerességi tényezők egy kistelepülés mindennapjaiban.

Mivel nem minden vizsgálatba vont település polgármestere volt nyitott az interjúadásra, törekedtem arra is, hogy a helyi elit egyéb tagjaival is készüljenek interjúk, lehetőleg olyan személyekkel, akik a szakirodalmi előzményekben fejlődést előidéző tényezőhöz szakmájuk révén kapcsolódnak. Veleméren többszöri megkeresés ellenére sem adtak interjút, sem a helyi elit tagjai, sem a polgármester.

A polgármesterek és a helyi elit véleményét a lakossági kérdőívek kérdéseihez hasonlóan szintén nem az „Ön szerint siker-e az, hogy (...)?” típusú kérdésekkel mértem fel. A polgármestereknél és a helyi elit tagjainál a statisztikai eredményektől és a lakossági kérdőívek válaszaitól független módon érdeklődtem a sikerről, annak a helyi elit által fontosnak tartott faktorairól.

Vizsgálatom részét képezte a kutatott falvak épületállományának felmérése is. Az ilyen típusú kutatásokra a szakirodalomban kevés példa található (MADARÁsz I. 2011). Az épületállomány felmérés kapcsán mind a 16 vizsgálatba vont település valamennyi lakóegységének kategorizálása megtörtént. A lakóegységek 4 kategória mentén kerültek bejelölésre: rossz állapotú lakóegység, átlagos állapotú lakóegység, jó állapotú lakóegység, üdülő. Minden esetben a rendelkezésre álló HisziMap térképtől [10], vagy www.maps.google.com [15] műholdfelvételtől eltérő - új építésü lakóegységeket is bejelöltem a vizsgálatba vont falvak térképein. Mivel több településen nagyszámú új lakást mértem fel, elvégeztem a faluállomány lakásépítési tendenciájának vizsgálatát is, melynek területiségét a vizsgálatba vont falvakhoz kapcsolódva elemeztem.

A terepbejárás során valamennyi vizsgálatba vont településen fotódokumentációt készítettem, mely a dolgozat ábraanyagában fellelhető. A kutatott falvak honlapjainak képi anyagát leválogatva tartalomelemzést végeztem. A fényképes ábraanyagot a disszertációban a szociológiai, politikai kutatásokból jól ismert tartalomelemzés módszerével elemeztem. A tartalomelemzés során a Berelson által kidolgozott módszert alkalmaztam, vagyis a kommunikáció „manifesztált tartalmát objektíven, szisztematikusan és kvantitatív eszközökkel" írtam le (BERELSON, B. 1952). A disszertáció fényképelemzése során a szemantikai tartalomelemzését vettem alapul, ezen belül is a megnevezés analízist - vagyis hogy egyes személyeket, dolgokat, 
tárgyakat hányszor említenek meg a szövegben (JANIS, I. L. 1965, MAJOROS P. 2004). Ezt a módszert adaptáltam át disszertációba, oly módon, hogy a 16 vizsgálatba vont falu honlapjain fellelhető összesen 1134 leválogatott fényképét elemeztem az alábbiak szerint. A statisztikai adatelemzésben sikerességi faktoroknak bizonyult tényezőkről (intézmények, kereskedelmi egységek, szolgáltatások, idegenforgalmi adottság, gazdasági tényezők, közlekedési feltételek, közösségi értékek) egy előre maghatározott kategóriarendszert állítottam fel, a fényképeket elemezve kódoltam a korábban említésre került kategóriarendszer objektumainak meglétét a fényképeken, valamint az előzetes kategóriarendszert bővítettem olyan objektumokkal és tényezőkkel, amelyek a fényképeken láthatóak voltak, de a statisztikai adatelemzés során nem voltak hangsúlyos tényezők. Az így nyert, a honlapokon a településk által saját magukról kommunikált további tényezőkkel bővítettem az előzőleg ismertetett módszerek által nyert sikerességi tényezők körét.

A kutatás során alkalmazott módszerek közül a statisztikai adatelemzés és a kérdőíves adatfelvétel, valamint a helyi elit tagjaival folytatott interjúk kapcsán fontos hangsúlyozni, hogy ezek a módszerek nem egymás eredményeinek megerösítése érdekében kerültek alkalmazásra. Vagyis az elsőként elvégzett statisztikai adatelemzés eredményeinek további bővítése érdekében került sor lakossági kérdőívezésre. A statisztikai adatelemzés és kérdőíves adatfelvétel eredményeinek további bővítése érdekében került sor interjúk készítésére, csakúgy, mint az épületállomány felmérésére, valamint a fotódokumentáció elemzésére is. Példának okáért, a statisztikai vizsgálatot követő kérdöíves felmérésben nem az volt a vizsgálat tárgya, hogy a statisztikailag fejlett falvak lakosai hogyan viszonyulnak a statisztikai sikerességhez, hanem az, hogy a statisztikailag lehatárolható sikerességi tényezők megegyeznek-e a lakosság által megnevezett sikerességi tényezőkkel, illetve, hogy a lakossági kérdőívek milyen új, a statisztikai vizsgálatokban nem kimutatható sikerességi faktorokat adnak. A „kívülrôl” lehatárolható, a kvantitatív módszerekkel mért, valamint a helyi társadalom által megfogalmazott fejlődést előidéző tényezők minél szélesebb körü meghatározása, egymással való összevetése volt tehát a cél, a különböző módszerekkel elérhető eredmények közti hasonlóság és különbség bemutatása mellett.

A különböző módszerekkel nyert eredmények bemutatásához a disszertáció ábrái és térképei a MapInfo Professional ${ }^{\circledR} 10.5$ és az Adobe Photoshop CS6 ${ }^{\circledR} 13.0$ verziójával készültek. 
A disszertáció természetesen több irányba is bővíthető lenne a kutatási eredmények további pontosítása érdekében. A sikerre, mint értékkategóriára az elsősorban külföldi szakirodalomban teret nyerő kutatási problematikával egyetértve, a „helyi, nem elit réteg” oldaláról is fontos lenne tekinteni (TiMÁr J. - VELKEY G. 2003, Boros L. - HegedÜS G. - PÁL V. 2007). A teljesség igénye nélkül pl. a turisták, vagy a helyi marginalizálódott csoportok véleménye is fontos lehet, hiszen így egyértelmübben elkülöníthető lenne, hogy a siker „kinek a sikere”, ki hogyan éli meg a települési sikerességet. Valamint további kutatási terület lehetne az eredmények alapján felállított sikeres aprófalu modelljének tesztelése is. 


\section{SZAKIRODALMI ELMÉLETI KERETEK, FOGALMAK}

\subsection{Az aprófalu fogalma, az aprófalvas településállomány területfejlesztési aspektusai, differenciálódása}

A hazai faluállománnyal foglalkozó kutatások nem konzekvensek annak tekintetében, hogy mely településeket nevezik aprófalunak. A szakirodalom szerint kétféle meghatározás elfogadott, mindkettő e kis települések lélekszáma alapján határolja le az aprófalvakat. Az egyik nézetcsoport szerint az 1000 fő alatti települések tekinthetők aprófalunak (PERCZEL K. - GerLE Gy. 1966, LETTRICH E. 1975, Nyitrai I. 1984, VÁGi G. 1985, Fleischer T. 1991, CSAPó T. 1993, KÖSZEGFAlVi GY. - TóTH J. 2002). A másik nézetcsoport szerint, a szakirodalmak többségében viszont az 500 főnél kevesebb lakosú falvakat fogadják el e kategória részeseinek (KÖRMENDI K. 1976 a, KÖRMENDI K. 1976 b, ENYEDI Gy. 1980, BELUSZKY P. 1984, ENYEDI Gy. 1984, SiKos T. T. 1990, Hubai J. 1992, DövÉnyi Z. 2003, Balogh A. 2008). Az 500 fö alatti falvak csoportjának megnevezésére a szakirodalom alkalmazza a törpefalvak definíciót is (Mohos M. 1996, KőSzegfalvi Gy. - Loydl T. 2001). Disszertációmban az 500 fős beosztást használom, valamint az aprófalu elnevezést alkalmazom, vagyis a továbbiakban aprófalu alatt az $\mathbf{5 0 0}$ fónél nem népesebb településeket értem.

A fent definiált kisfalvak területi elhelyezésüket tekintve a Kárpát-medence hagyományos települései, a középkori magyar településhálózat meghatározó elemei voltak egészen a török hódoltságig. A török fennhatóság ideje alatt azonban a nagyhatárú településforma vált uralkodóvá az Alföldön, így az aprófalvak csak a hódoltság által nem érintett területeken maradtak fenn (MoHOs M. 1996). A települések népességnagyságrendje és a különböző magassági szinteken való elhelyezkedés között is szoros kölcsönhatás áll fenn, e mellett a talajviszonyoknak és az úthálózatnak is jelentős szerep jut. Major Jenő rámutat arra, hogy az apró- és kisfalvak és az erdei, lápi és öntéstalajok elhelyezkedése között szoros az összefüggés. E területeken az intenzívebb mezőgazdaságnak és ezzel együtt a népességnövekedésnek is alapvető korlátai voltak (PERÉNYI I. - FARAGÓ K. - MAJOR J. 1962). Az aprófalvak elterjedési területei ma nagyjából a hegy- és dombvidékekre tehetők, elsősorban a peremterületeken vannak jelen nagy számban, de azokon a területeken is megmaradtak, ahol a török hódoltság nem érintette a településszerkezetet, pl. Szabolcs-Szatmár-Bereg 
megyében (KÖRMENDI K. 1976 b, ENYEDI GY. 1980, ENYEDI Gy. 1984, LACKÓ L. 1992 a). Eloszlásuk egyenlőtlen, Dél- és Nyugat-Dunántúlon összefüggő tömbben jelennek meg, máshol egy-egy megye településhálózatának meghatározó elemei (BELUSZKY P. 1984). Legmagasabb az aprófalvak száma Baranya, Zala, Borsod-Abaúj-Zemplén, Vas, Somogy és Veszprém megyékben (BALOGH A. 2008).

Ezeket a kistelepüléseket hosszú ideig homogén településegységként kezelték a kutatások során. Falvaink azonban az 1950-es évektől erőteljesen differenciálódni kezdtek. Általánosságban elmondható, hogy az 1950-es, 1960-as években a nagyobb népességgel rendelkező, kedvezőbb fekvésű, esetlegesen központi szerepkört betöltő települések gyorsabban fejlődtek, mint a kisebb népességgel rendelkező, a gazdasági fejlődés feltételeit megteremteni kevésbé tudó társaik (KÖRMENDI K. - KULCSÁR V. 1976). A falvak differenciáltsága a bennük élő lakosság sokszínüségével is együtt járt. Az 1960-as években a falvak lakosságát döntően mezőgazdasági munkások, bortermelők, mezőgazdasági és erdészeti munkáltatók alakották, köztük a diplomások száma meglehetősen kevés volt (MoLNÁR L-NÉ. 1970). Ebben az időszakban, az 1950es évektől az 1970-es évek elejéig a falusi lakosság jelentős része elvándorolt, másfélmillió ember költözött a faluból a városba (ENYEDI GY. 1980).

Az 1970-es, 1980-as években a differenciálódás hátterében már olyan folyamatok álltak, mint a mezőgazdasági termelés eltérő színvonala, az alapfokú ellátás megléte, valamint a jövedelemszerzési lehetőségek eltérései (BELUSZKY P.-SIKOS T. T. 1982). Az alapellátási intézményekben, és a lakosság foglalkozási megoszlásában keresendő differenciáló okok mellett a falusi lakásviszonyokat is a különbözőséget okozó tényezők között említhetjük (ENYEDI GY. 1980). Az aprófalvak átalakulási folyamataiban tehát ezekben az évtizedekben meghatározó a településszerkezet, az ipar, mezőgazdaság feltételei, a természeti adottságok, és a földrajzi fekvés (AUBERT A. - ZSIBRIK I. 1984). Míg az 1950-es években a viszonylag magas (11\%-os) természetes szaporodás értéket az elvándorlás jelentősen visszavetette, addig az 1970-es, 1980-as években az elvándorlás mellett a természetes szaporodás mértéke is visszaesett ezeken a kistelepüléseken (KLINGER A. 1976, KovÁCs T. 1984). A lakóhely-változtatások döntő részét - mind az állandó, mind az ideiglenes vándorlások esetében - a munkával kapcsolatos közvetlen vagy közvetett okok idézték elő (NAGY K. 1976). Összességében az aprófalvak közti gazdasági és társadalmi különbségek vizsgálata kapcsán elmondható, hogy míg az 1950-es, 1960-as években a településméret volt a legfőbb differenciáló tényező, addig az 1970-es, 1980-as években a városhoz való kapcsolódás 
lehetősége (BELuszKy P. - SiKos T. T. 1982) különítette el a dinamikus, fejlődő és a depresszív, fejletlen aprófalvakat egymástól.

A földrajzi helyzet és a városhoz való kapcsolódás lehetőségeinek hiánya révén kialakuló depresszív területen elhelyezkedő aprófalvak többsége nap, mint nap szembetalálja magát a „kisfalu-szindróma” jelenségével. Nem véletlen tehát, hogy az 1970-es, 1980-as években nagyobb részt depresszivitás, kisebb részt dinamizmus tekintetében az aprófalvakat a kutatók meglehetősen sokat vizsgálták. Az ezekben az években leírt depresszív térségeket jellemző tünetcsoport tényezői a mai fejletlen térségekre is jellemzőek, ezeket a továbbiakban ismertetem. A dinamikus térségek fejlődését segítő tényezőinek köre viszont mára jelentősen módosult, melyeket statisztikai és empirikus módszerekkel végzett vizsgálatok eredményeivel alátámasztva a disszertációban a későbbiekben szintén ismertetek.

A depresszív térségek kistelepülésein a társadalmi hátrányok halmozódnak, nincsenek demográfiai reprodukciós tartalékok, a propagatív korosztály hiányzik, a vitalitási mutatók messze elmaradnak az országos átlagtól (ENYEDI GY. 1980), a népesség szociális, kommunális, kulturális, ellátottsági mutatói folyamatosan romlanak (KÖRMENDI K. - KulCSÁR V. 1976). Az elvándorlás mértéke magas, a társadalmi mobilitás egyértelműen kifelé vezet a depresszív aprófalvakból, gyakori a gyors, olykor menekülésszerü elvándorlás, mely munkaerőhiányt és ezzel együtt deklasszálódást okoz az adott településen (ERDEI F. 1940, ENYEDI GY. 1980). Az elvándorlás szelektív a depresszív aprófalvakban, a magasabb iskolai végzettséggel rendelkezők és a fiatalok költöznek el a településről, gátolva ezzel a demográfiai reprodukció lehetőségét (BELUSZKY P. 1984). Az elvándorlás hátterében olyan okok állnak, mint hogy a szakképzett munkaerő, a diplomások falujukban nem találnak munkát, több müszakos munkára lehetetlen ingázni, infrastrukturális hiányosságok, tőkehiány jellemzi a falut (MoHos M. 1984). A torzult, kedvezőtlen demográfiai struktúra, a demográfiai erózió sajátja lehet az elöregedés, természetes fogyás és az alacsony iskolai végzettség mellett esetenként a teljes elnéptelenedés is ${ }^{12}$ (ENYEDI GY. 1980, KÖRMENDI K. 1976 b). Az 1970-es, 1980-as évek nagyüzemi gazdálkodása is általában az 500 főnél népesebb településeken alakult ki és az ehhez kapcsolódó élelmiszeripar sem az aprófalvakat dinamizálta (ENYEDi GY. 1980, BeluszKY P. - SikOs T. T. 1982, BELUSZKY P. 1984),

${ }^{12}$ Erre a sorsra jutott pl. Gyürüfü. De pl. Gorica, Révfalu, Korpád, Kán, Mónosokor, vagy Szatina települések lakosságszáma is nullára, vagy csupán néhány före csökkent. A falvak népességvesztése azonban a településegyesítések hatására rejtve maradt. 
mint ahogyan napjainkban sem jellemzö a depresszív kistelepülésekre ipari, vagy korszerü mezőgazdasági tevékenység folytatása. Jellemző továbbá a fejletlen térségek falvaira, hogy a lakásállomány folyamatosan romlik, a müvi környezet, az emberkéz alkotásai pusztulnak, az épületek kora a nagyobb lélekszámú településekhez viszonyítva magas, valamint, hogy a kedvezőtlen életkörülmények szegénységgel társulnak és a kistelepülés gyakran leépülési spirálba kerül (ENYEDI GY. 1980, BELUSZKY P. 1984).

A dinamikus térségekben elhelyezkedő fejlődőképes aprófalvak jellemzőinek bemutatása a későbbiekben külön fejezetben történik, ezen áttekintés kapcsán csak annyit kívánok megjegyezni, hogy a sikeres aprófalvak fejlődését előidéző tényezők köre igen sokrétü, és az elmúlt évtizedekben meglehetősen sokat módosult. A dinamikus térségek tényezőinek lehatárolása nem csak az elmúlt évtizedekben bekövetkezett tényezőmódosulások miatt fontos, hanem azért is, mert a szakirodalomban az „aprófalvas-szindróma” mintegy ellenpólusaként minél szélesebb módszertannal megvizsgált, lehatárolt és megnevezett fejlődést, sikerességet eredményező tényezőcsoport megadására eddig nem került sor. Holott a fent részletezett differenciáló tényezők mentén a falvak, és köztük az aprófalvak is jelentős átalakuláson mentek keresztül az elmúlt évtizedek során.

A differenciáló tényezők évtizedenként eltérő volta miatt a települések csoportosítása is különböző szempontok szerint, más súlypontok mentén történt az elmúlt években. Az 1950-es évek előtt a falvak alaprajz szerinti csoportosítását végezték el többen (ERDEI F. 1940, GYŐRFFY I. 1943, LÁsZló GY. 1944), mely csoportosításokban a szabályos parasztfalvak, óriásfalvak mellett megjelentek az uradalmi falvak vagy a kertes, csürös települések is, mint településföldrajzi kategóriák. Az 1950-es, 1960-as falutipizálások során továbbra is szempont maradt a morfológiai sajátosság, mint a csoportosítás egyik tényezője (MENDÖL T. 1963), az 1970-es, 1980-as években az alaprajzi tipizálás mellett (KÖRMENDI K. 1976 a) azonban már a foglalkozási szerkezet mentén leírható gazdasági falutípusok (KULCSÁR V. 1976), az agrár-urbánus falutípusok (LETTRICH E. 1975), vagy a foglalkozás, nagyságrend, demográfiai tényezőket egyaránt figyelembe vevő falutípusok (ENYEDI GY. 1980, BELUSZKY P. - SiKOS T. T. 1982) kerültek kialakításra.

Az aprófalvas településállományt differenciáló tényezők között az 1990-es évek során, és azt követően is fontos szerepü maradt a földrajzi fekvés, mint elkülönítő tényező (ENyedi Gy. 1996, Nemes N. J. 1997, BAJMócy P. - BAlOGH A. 2002, BELUSZKY P. 2007), ugyanakkor a munkához kapcsolódás lehetősége is felértékelődött. 
Nem véletlen, hogy a hangsúly az 1990-es években a települések csoportosítását tekintve áttevődött a föbb települési funkciók szerint végzett csoportosításra. Így beszélhetünk ellátási funkció, igazgatási funkció, termelési szint, speciális funkciók, lakófunkció szerinti település lehatárolásokról (VALÉR É. 1990), üdülőfalvakról, stagnáló, fejlődő aprófalvakról (MOHOS M. 1996) a kistelepülések faluállományát tekintve.

Napjainkban a differenciáltság az aprófalvas településállomány elemei között már olyan mértékü, hogy néhány társadalmi-gazdasági mutatót vizsgálva (pl. foglalkoztatottak aránya, iskolai végzettség) a településlisták első és utolsó helyein is találhatók aprófalvak, különösen igaz ez az országos listák első tíz helyezettjére (BAJMÓCY P. - JÓZSA K. - PóCSI G. 2007). A települések csoportosítása során napjainkban megjelennek a kimondottan jó helyzetủ aprófalvas csoportok, pl. az osztrák határ mente jobb infrastrukturális helyzetü aprófalvai (KÖSZEGFALVI GY. - LOYDL T. 2001), a jó munkaerőpiaci helyzetü, stabil társadalmú kisfalvak (BELUSZKY P. - SIKOS T. T. 2007), vagy a döntően nyugat-magyarországi dominanciájú fejlett aprófalvak (BALOGH A. 2008) is.

Azt, hogy a kistelepülések differenciálódása milyen módon alakult, és a differenciáló tényezők milyen prioritások szerint változtak, nagymértékben befolyásolta a településpolitika. A fent említett aprófalvakat a településpolitikai döntések - a gazdasági prioritások elötérbe állításával - már az 1950-es évek óta érintették, vagyis a településpolitika kialakulásától (LACKÓ L. 1992) kezdve. Az 1950-es években nagyszámú faluösszevonásra került sor, falurombolási tervek készültek, a településhálózat fejlesztendő elemeit a nagy lélekszámú települések jelentették (BELÉNYI GY. 1996, HAJdú Z. 2005).

Talán nem is meglepö, hogy a kisfalvak az 1960-as években a megszüntetendő települések közé kerültek, és egészen az 1990-es évekig siettették a felszámolásukat (BEluszKy P. - Sikos T. T. 1982, BeluszKy P. 1984). Bár az 1963-ban napvilágot látott Magyarország Településhálózat-fejlesztési Tanulmányterve címü dokumentum mely szerint a 3000 fö alatti települések nem számíthattak fejlesztésre - végül nem vált hivatalos dokumentummá, sokat jelzett előre a kistelepülések későbbi években zajló fejlesztési irányairól, kijelölve a differenciálódás útját.

Az 1971-ben elfogadott Országos Településhálózat-fejlesztési Koncepció (OTK) a kistelepülések számára annyiban jelentett változást, hogy a korábbi „mellékfalukat” immár „egyéb településekként” említette, de továbbra is hangsúlyozta a 
funkciónélküliségüket, az alsó fokú központi szerepkörre való alkalmatlanságukat. Az 1970-es évek a körzetesítések időszakát hozták, az „egyéb” falvak intézményhálózatának felszámolását, közös tanácsok, mezőgazdasági szövetkezetek létrehozását, iskolák összevonását (MoHos M. 1996). Mindezek ellenére a falvak mégsem haltak ki tömegesen.

Az 1980-as évek viszont kedveztek a falunak, az OTK 1981-es módosítása szerint a közép- és kisvárosok, és a községek súlyát kellett növelni (FARAGó L. 1993). 1985ben az országgyülés határozatot hozott - ez volt az első ilyen - a terület- és településfejlesztés hosszú távú feladatairól (LACKÓ L. 1992 b), és eltörölte a települések szerepköri megkülönböztetését (HAJDÚ Z. 2005).

A rendszerváltozást követően minden közigazgatásilag független település megkapta az önálló döntés lehetőségét, így a legapróbbak is szabadsághoz jutottak. A rendszerváltozást követő szabadság önmagában azonban kevés volt, gazdasági, társadalmi eredmények is szükségeltettek a pozitív változáshoz, így a megváltozott helyzethez a kedvező helyzetü, erős társadalmi identitású, agilis vezetővel bíró kisközségek tudtak leginkább alkalmazkodni (P. KovÁCs. I. 1993, BÖHM A. 1999).

Összefoglalva tehát a disszertációban az 500 főnél nem népesebb településeket értem aprófalu alatt. Az aprófalvak a Kárpát-medence meghatározó településszerkezeti elemei. Az 1950-es évektől az aprófalvas településállományt differenciáló tényezők köre a településpolitikai döntésekhez igazodva folyamatosan változott. Az 1950-es, 1960-as években a nagyobb lélekszámú, központi szerepkört betöltő falvak fejlődtek, az 1970-es 1980-as években fontos szempont volt a városhoz való kapcsolódás, az 1990-es évektől napjainkig tartó időszakban felértékelődött a földrajzi fekvés és a munkához való kapcsolódás lehetősége. A differenciáló tényezők alapot szolgáltattak a falvak csoportosításához, és kijelölték a depresszív és dinamikusan fejlődő térségeket. A depresszív térségek jellemzőit a „kisfalu szindróma”, vagy „,aprófalvas szindróma” tünetcsoportja fogja egybe. A dinamikus, fejlődő falvak, esetlegesen térségek sikerességének tényezői nem lehatároltak. 


\subsection{A sikeresség tényezőinek lehatárolása a települési sikerfogalmak vizsgálatán keresztül}

A depresszív térségekre jellemző tulajdonságcsoport, azaz az ,aprófalvas szindróma” jelensége egy jól lehatárolt tényezőcsoport a szakirodalomban. A dinamikus térségek falvainak jellemző tulajdonságcsoportja, sikerességük tényezői azonban jól lehatárolva nem lelhetők fel, a szakirodalomban csupán egy-egy tényező megnevezése történik. Ahhoz, hogy a disszertáció céljai között kitüzött sikerességi tényezőcsoport megadható legyen, a továbbiakban a dinamikus térségek fejlődést előidéző tényezőit ismertetem, a verseny, sikeresség fogalmának nagyobb, majd kisebb léptékü megközelítése felől.

A disszertáció egyik legvitathatóbb eleme kétségkívül éppen a sikeresség fogalmának használata a vizsgálat során, mivel a legtöbb települési sikerességgel foglalkozó szakirodalom a sikert értékkategóriaként kezeli (ENYEDI GY. 1997, JENSENBUTLER, C. 1997). A legtöbb esetben úgy, hogy a sikert, sikerességet gazdasági értékek mentén méri, felvetve azt a problémát, hogy a gazdaságilag sikeres települések más mutatók mentén esetlegesen nem lennének azok. Ezekben az esetekben a sikeresség fogalma igen gyakran összekapcsolódik a versenyképesség fogalmával ${ }^{13}$. Ez azért is érhető, mivel a történelem során a települések - legyen az nagyváros, vagy aprófalu között mindig folyt valamiféle versengés. A területi verseny, a települések közti versengés tehát nem új keletü dolog. A korábbi évszázadokban a vásártartás jogáért, megyeszékhellyé, püspöki székhellyé válásért versenyeztek a városok, míg az ókorban és a középkorban azok a városok voltak sikeresek, amelyek a környező településeket hatalmukba tudták keríteni (SÁRI I. 2001, BENEvolo, L. 1994). Az ipari forradalom idején a fejlett iparral rendelkező, a szocializmus idején a „szocialista városok”, a rendszerváltozás után a piacgazdasági változásokra gyorsan reagálni tudó városok voltak a szakirodalomban leírtak alapján sikeresek (SÁRI I. 2001).

A verseny általánossá válása az 1990-es évektől megfigyelhető. Ezt politikai, gazdasági hatások indukálták, vagyis a gazdasági szerkezetváltás és a világgazdasági globalizáció (ENYEDI GY. 1997). A területi verseny tehát olyan folyamat, ahol a

\footnotetext{
${ }^{13}$ Itt kívánom megjegyezni, hogy a versenyképesség fogalmát jelen disszertáció a korábbi szakirodalomra támaszkodva a sikernél szükebb kategóriaként, annak feltételeként kezeli különösen a falvak sikerességének tárgyalásakor (ENYEDI GY. 1997), mondván a versenyképességet befolyásoló tényezők igen összetett körét napjainkban a sikeresség fogalma fogja össze (LUKÁcS G. S. 2008). Fontos megjegyezni, hogy a siker szinonimájaként a továbbiakban a fejlett, fejlődő kifejezéseket is alkalmazom, a szóismétlés stilisztikai hibájának csökkentése érdekében.
} 
gazdasági fejlődés megteremtése, előmozdatása a cél explicit, vagy inplicit módon. A célok is definiáltak, forrásszerzés, népességnövelés, a foglalkoztatás növelése, a beruházások ösztönzése, stb. Az is elmondható azonban, hogy sok esetben csak a „látványt” ismerjük, az új, vagy éppen hanyatló elemeket látjuk (MÉSZÁROs R. 1993), a bevezetőben említett mi? - ki? - hogyan? kérdéskör tényezőit, vagyis az előidéző okokat, szereplöket, és a módot, ahogyan a folyamat zajlik, azonban nem, vagy csak részben. Fontos tehát azoknak a mechanizmusoknak a megismerése, amelyek ezeknek az új, vagy éppen hanyatló elemeknek a meglétét előidézik.

Az 1990-es években Magyarországon a gazdasági fejlettség értésskáláján mért versenyképesség, sikeresség alkalmazása volt jellemző. Azonban ha a sikert értékkategóriának tekintem, véleményem szerint nem folytatható a települési siker, falvak sikeressége témakörben csak egyféle értékskála menti vizsgálat. Mint ahogyan a fent jelzett módon nem fogadom el a versenyképesség és a sikeresség definícióbeli azonosságát, a versenyszemléletben, gazdasági értékek mentén mérhető sikerességet sem tekintem egyedüli lehetőségnek a vizsgálatok során. A hazai szakirodalomban is föleg a 2000-es évektől - megjelenik az a felfogás, mely a versenyszemléletü vizsgálatok mellett, a gazdasági mutatókat egyfajta indikátornak elfogadva hangsúlyozza azt, hogy más típusú indikátorok mentén is mérhető a sikeresség (TIMÁR J. - VelKey G. 2003). Hivatkozott kutatásban a statisztikaialag mérhető városi sikerességet a helyi társadalom véleményével vetették egybe, rámutatva arra, hogy a statisztikailag sikeres városokat a helyi társadalom tagja nem feltétlenül tartják sikeresnek. A kutatás igazolta azt is, hogy a vizsgált városok lakosai a sikert nem csak gazdasági értékek mentén mérik, a kulturális fejlődés legalább annyira fontos, mint a gazdasági előbbrejutás.

Meg kell említeni, hogy a nemzetközi szakirodalomban már az 1960-as évektől hangsúlyos az anyagi szükségletek kielégítésére irányuló tényezők kutatása mellett az immateriális javak feltárása is. Sőt, sok esetben az ilyen típusú kutatásokat, és később néhány hazait is, a sikeresség fogalma mellett az életminőség fogalma fog egybe (UTASI Á. 2006). A kutatások jelentős része az egyén ,jól-lét” érzését vizsgálja (KoPP M. 2006). Mivel azonban a ,jó, jobb” életminőség, a ,jól-lét” vizsgálata önmagában is egy doktori disszertáció vizsgálai tárgyát képezi, különösen a szakirodalomban fellelhető fogalmi problémák miatt, így doktori disszertációban nem térek ki az életminőséggel kapcsolatos kutatások szakirodalának ismertetésére. 
Úgy vélem, ha a városok sikerességével foglalkozó, átfogó kutatásban, illetve az életminőséggel foglalkozó kutatásokban is igazolódott a versenyszemlélettől eltérő értékek mentén való mérés létjogosultsága, akkor kisebb földrajzi léptékben, az aprófalvas kutatásoknál a sikeresség, mint értékkategória kutatása, a helyi társadalom oldaláról szemlélve elengedhetetlen. Éppen ezért fontosnak tartom hangsúlyozni, hogy a disszertáció célja nem a települési siker egyoldalú értékkategória mentén való vizsgálata (már csak ezért sem lenne szerencsés az életminőség fogalmainak részletes ismertetése). A cél többféle értékskála mentén való sikerességi tényezőcsoport lehatárolása, rámutatva arra, hogy a különböző értékrendszerek szerint mérhető és megadható sikerességi tényezők között mely faktorok egyezősége figyelhető meg, valamint arra, hogy a különböző értékek mentén mérve mely tényezők megléte a legfontosabb. A siker fogalmát használó szakirodalom jelen esetben tehát az eszköz arra, hogy a különböző értékskálán mért „sikerek” tényezői lehatárolhatók legyenek, valamint a szakirodalmakban fellelhető sikerességi tényezők alapján megadható legyen egy olyan aprófalvas sokaság, amelyben konkrét terepi kutatások végezhetők.

Íly módon a szakirodalmakban fellelhető siker-definíciókat feldolgozva nem feltétlenül az a fontos, hogy mely értékek mentén mérték a siker fogalmát, hanem hogy milyen különböző sikerességi tényezőket neveztek meg. Hiszen ennek a szakirodalmi feldolgozásnak a mentén választottam ki a vizsgálatba vont falvakat, majd a vizsgált aprófalvakat „kívülről” és „belülröl” kutatva határoltam le a mai aprófalvas településállomány sikerességének tényezőit. Mivel a szakirodalmakban a siker fogalma leginkább nagyobb területegységre meghatározott, így a regionális, megyei szinten fellelhető sikerfogalmakat is áttekintettem, viszont azok tényeizőire (az életminőséghez hasonlóan) léptékbeli különbözőség miatt csak röviden teszek utalást.

Országos szinten tehát a sikeresség tényezőjének tekinthető az, hogy az ország világosan meg tudja fogalmazni érdekeit, az országban jelen van a társadalmi kohézió, ami az érdekérvényesítés nélkülözhetetlen feltétele (INOTAI A. - VERESS J. 2004). A sikeres régióban az előállított jövedelem növekedése, annak egy részének helyben maradása és településmüködtetésre fordítása jelentkezik a sikeresség faktoraként (ENYEDI Gy. 1997). A régiók, kistérségek sikerességének feltétele továbbá a foglalkoztatottak szolgáltatásokban és/vagy feldolgozóiparban való koncentrálódása, a könnyü megközelíthetőség, elérhetőség, a magasan kvalifikált munkaerő, valamint a szociális infrastruktúra, üzleti szolgáltatások megléte (LuKÁcS G. S. 2008). Vagyis nagyobb földrajzi lépték esetén a sikeresség versenyszemléletü megközelítésének 
tényezői fellelhetők, az hogy az adott ország, régió lakosainak milyen a viszonyulása az objektív módon, satisztikailag mérhető sikerhez, nem hangsúlyos, nem mért indikátor. A helyi társadalom sikerességhez való viszonyulása mellett nagyobb területi egység társadalma által megfogalmazott sikerességi tényezői sem kutatottak, nyilvánvalóan a lépték nagysága miatt.

Íly módon a nagyobb léptékü kutatásokban fellelhető sikerfogalmak további ismertetése helyett a kisebb léptékü, városi sikerdefiníciókban fellelhető sikerességi tényezőkre fókuszálok. Ennek oka a falvakéhoz idomuló léptékbeli kérdések mellett az, hogy a városi sikerességgel foglalkozó vizsgálatokban különböző értékek mentén folytattak vizsgálatokat a kutatók. A továbbiakban így az egyes sikerdefiníciókban fellelhető, különböző értékek mentén lehatárolt sikerességi tényezőket, indikátorokat ismertetem. Hangsúlyozom azt, hogy a sikertényezők csoportokba foglalása a továbbiakban azok milyensége, és nem az azokat felsorakoztató sikerességi fogalmak értékrendszere mentén történik. Így a különböző tényezőcsoportok esetében olykor több értékkategória mentén mért sikerességről beszélhetünk.

Ezek alapján a városok sikerességének tényezői között egyrészt olyan gyorsan módosuló elemek találhatók meg, mint pl. a városban élők jólétének növelése, gazdasági fejlődésének elősegítésével, amely fejlődést bizonyos csoportok a helyi politikákon keresztuil más térségekkel versengve, rivalizálva próbálnak befolyásolni (LENGYEL I. - RECHNitZER J. 2000; LENGYEL I. 2003). A versenyképességet megteremtő, sikert kiváltó tényezők körének gyors módosulása azonban nem új keletű jelenség, éppen ezért az időt álló tényezők megteremtésének fontosságára (pl. kreatív régió) külföldi kutatók már jóval korábban felhívják a figyelmet (ANDERSSON, A. 1985). Jómagam ez utóbbi állásponttal értek egyet, vagyis úgy gondolom, hogy a tartós sikeresség fenntartásához állandó tényezők jelenlétére, biztosítására van szükség a településeken.

A sikeresség gazdasági tényezői között a város tartós jövedelemgeneráló képessége mutatkozott sikerességi tényezőnek (JENSEN-BUTLER, C. 1997), mely egyben a fejlödést gátló elem is lehet, ha nem megfelelö helyen és módon hasznosul a generált jövedelem, és ha a városban jelenlévő érdekcsoportok egymásnak ellentmondó érdekekkel bírnak. Napjaink sikerességi tényezője lehet a látogatók számának növekedése, ezzel együtt a turisztikai bevételek, vagy a befektetett működőtőke növekedése is (BOROs L. 2003). A gazdasági tényezők fontosságát nem meglepő módon a versenyszemléletű megközelítésekben fogalmazták meg a kutatók. Azt gondolom 
azonban, a versenyszemlélet privilégiuma nem megengedhető a sikerességi tényezők minél pontosabb lehatárolása érdekében.

Több szakirodalom mér puha módszerekkel és közelít a sikerességhez a társadalom oldaláról. Egyre több szakirodalomban megtalálható a humán tőke, mint sikerességi tényező. Ezekben az irodalmakban a fejlődést előidéző faktorok között szerepel az, hogy a helyi önkormányzat és polgármester legalább egy, esetleg több cikluson keresztül a helyén marad, vagy éppen a polgárok jóléte és tenni akarása. Jellemző az, hogy döntően szociológiai kutatások mérnek a társadalom értékrendje szerint, úgy, hogy verenyszemléletben is vizsgálódnak. Gyakran nézik „fentről” a siker definícióját. Ebben az esetben akkor nevezhető sikeresnek egy település, ha nem adósodik el, miközben egyre kevesebb a rendelkezésére álló anyagi forrás és egyre kisebb költségvetésből gazdálkodik. De gyakran nézik ,alulról” is a sikert. E tekintetben sikeres egy település, ha müködnek a szociális szolgáltatások, az intézmények, közberuházások vannak a településen, vállalkozások indulnak (BóDI F. - BőHM A. 2000). Az ilyen típusú kutatásoknál tehát a versenyszemlélet megtartása és a társadalmi értékek mentén való vizsgálat egyaránt jelen van.

Disszertációmban egy fent leírtakat egyesítő állásponttal értek egyet, mely szerint a sikert komplexen kell értelmezni, több tényező együttes jelenléte adja a település sikerét (Level, W. F. 1993, Ashworth, G. J. - Voogd, H. 1997), a települési (városi) sikeresség tényezői folyamatosan változnak, a tartós sikeresség, fejlődés fenntartásához azonban szükség van állandó elemekre.

Az 1980-as évektől napjainkig tehát a sikerességi tényezőket tekintve az alábbiak módosulások figyelhetők meg. Az 1980-as években a szakirodalmi előzmények alapján a sikeres várost a következő módon jellemezhettük: képes alkalmazkodni az öt érintő változásokhoz, benne a tercier szektor térnyerése jellemző, melyben az értékhúzó ágazatok nagy számban jelen vannak. A sikeres városban felértékelődik a tudás, jelen van a $\mathrm{K}+\mathrm{F}$, erős az innovációs képesség. A város kiveszi részét az őt érintő döntéshozatalból, középosztálya gyarapodik, de megjelenik a marginalizálódás, a társadalmi konfliktusok is (HERBERT, D.-SMITH, D. M. 1989).

Az 1990-es évek kutatásai alapján a fent említett tényezők mellett a sikeres városok fejlődést ereményező tényezői között felértékelődtek olyan elemek, mint a jó konfliktuskezelés, a külkapcsolatok, a jövedelem és a foglalkoztatás növekedése valamint a szolidaritás vagy a tudás-alapú termelés (ENYEDI GY. 1997). 
Napjainkban a szakirodalmak szerint már több tényező együttes jelenléte elengedhetetlen a települési sikerhez. A legújabb kutatások olyan tényezőkről számolnak be, mint például a fejlett infrastruktúra, a település vonzereje, a humán erőforrás, vagy a település vezetésének aktivitása (NAGYVÁRADI L. - SZEBÉNYI A. 2008) ${ }^{14}$. De a lehetőségek, a cselekvőkészség, a civilizált keretek együttes jelenléte, ezzel együtt fejlődő gazdaság, munkahelyteremtés, képzések, megfelelő színvonalú infrastruktúra és a szolgáltatások jelenléte (LUKÁCS G. S. 2008) szintén a fejlődés fontos tényezői. Az elmúlt évtizedekben tehát a városok sikeressége kapcsán megfigyelhető egyrészt a megfelelő ellátottsági, infrastrukturális és gazdasági helyzet meglétének szükségessége és mindezek mellett a humán tényezők előtérbe kerülése, a lakosság és a településvezetés aktivitásának felértékelődése a város sikeressége szempontjából.

Látható tehát, hogy néhány évtized alatt a sikeresség mérése más-más értékrendek mentén történt, valamint, hogy napjainkra a társadalmi értékek felértékelődtek a versenyszemléletủ kutatások mellett. Elmondható az is, hogy a sikeresség tényezői a városi kutatásokban folyamatosan változtak. Fontosnak tartom azonban azokat a tényezőket is lehatárolni, és megnevezni, amelyek az elmúlt évtizedek vizsgálatai és saját kutatási eredményeim alapján időt álló, állandó sikerességi tényezőknek nevezhetők, ezt a későbbi fejezetekben statisztikai adatelemzés és empirikus kutatás módszerét felhasználva teszem meg.

Fontosnak tartom továbbá azt is, hogy a falvak szakirodalmát is áttekintsem, annak érdekében, hogy a sikerességről, annak elemeiről, a településállomány legkisebb elemei oldaláról is képet kaphassak. Legszembetünőbb különbség a városok és a falvak szakirodalma között az, hogy a korábbi sikerdefiníciók számos eleme megjelenik ugyan a falvak sikerességének esetében is, de átfogó sikerdefinícióval a falvak esetében nem találkozunk. A kutatók jelentős része alapvetően a rendelkezésre álló erőforrások oldaláról vizsgálódik, úgy hogy a vizsgálatok többsége egy-két sikerességi faktort hangsúlyoz. Megfigyelhető az is, hogy az önkormányzatok, településvezetés és lakosság szerepe a falvak sikerességében is csak az utóbbi években értékelődik fel, és valószínűsíthetően a méretbeli eltérés miatt a társadalmi tényezők felértékelődése a falvakban erösebb.

14 Jól példázza ezt Kozármisleny. A szuburbanizációs folyamatok hatására a pécsi agglomerációs településen rövid időn belül jelentős népességnövekedés következett be. Az új telkek időben történő kijelölése a városban kiváló alapot szolgáltatott a migráció megindulásának. 
A sikerességi tényezők az elmúlt évtizedekben az alábiak szerint változtak. A falvak fejlődését kutató vizsgálatok egy része infrastrukturális és ellátottsági tényezők fontossága felől közelített a falvak sikeressége felé. Az 1980-as években egyik fejlődést elősegítő tényezőként az alapellátás feltételeinek megteremtése jelentkezett - lakás, ivóvíz, villamos energia, út, gyermekintézmények, kereskedelmi ellátás, szolgáltatások (KőSZEGFALVI GY. 1984). A kutatók nagy része egyetértett abban, hogy nem lehet mindent mindenhol megteremteni, az esetek jó részében szükség van települési összefogásra. Az 1990-es években visszatérő fejlesztési prioritásként, a sikerességhez vezető úton a tudományos publikációkban a kistérségi szövetségek létrehozása (G. FeKETE É. 1993), illetve a településrendezési tervek kialakítása (CSATÁRI B. 1993) szerepelt. A felemelkedéshez vezető úton a pályázatok, vállalkozásélénkítés is hangsúlyosak voltak (FARAGÓ L. 1993). A falusi sikerességgel foglalkozó újabb szakirodalmak egy részének megállapításai szerint viszont csak akkor tekinthető sikeresnek egy falu, ha képes a mai kor elvárásainak megfelelő struktúrát úgy kialakítani, hogy közben képes megőrizni múltjának örökségét is (K. SoMOGYI G. 2000) $)^{15}$.

Visszatérő fejlesztendő elem az 1980-as évektől kezdve a közlekedési és települési feltételek javítása (ENYEDI GY. 1980, CSAPÓ T. 1993). Annak ellenére is, hogy a közlekedési feltételek javítása problémás, hiszen a kistelepülések lakossága számára az lenne ideális, ha minél rövidebb idő alatt minél kevesebb megállással jutnának el a célállomásukhoz, ami viszont a közlekedési társaságok szempontjából nézve nem lehet nyereséges (ERDőSI F. 1984). Így ma több olyan aprófalu létezik, ahol az iskolában az órakezdést a Volán járatok menetrendjéhez igazították, így segítve a közlekedési helyzet nehézségein (SzÉKELY GY. 2006).

Más megközelítések szerint a helyi adottságok megléte, és kiaknázása a sikeresség egyik faktora. Az idegenforgalmi lehetőségekre való alapozás már az 1980as években is a fejlődést elősegítő faktorként jelentkezett az aprófalvas kutatásokban, de csak ott, ahol a funkcióleépülés még megfordítható folyamat volt. Programok, a falu megismertetése, fizetővendég-hálózat kialakítása voltak elengedhetetlen tényezők a fejlődéshez (Vuics T. 1984). Az 1990-es években a mezőgazdasági termelést, mint a falvak másik fontos adottságát, csak legfeljebb lokális szinten való megélhetési

\footnotetext{
${ }^{15}$ A Villány-Siklósi Borút települései a borút program révén megőrizték hagyományaikat, a termékeik egyediségét, ami egyértelmü versenyelőnyt jelent a települések számára, és mindezek mellett a szőlőterületek nagysága sem csökkent az új technológiai eszközök bevezetése során.
} 
forrásként nevezték meg (NEMES N. J. 1993), sok esetben a mezőgazdasági termelés fogalma összekapcsolódott a kényszervállalkozók fogalmával, miszerint a gazdaság ezen szektora remélhetőleg munkaalkalmat teremt a - más lehetőséget nem talált falusi vállalkozóknak (SÜLI-ZAKAR I. 1993). A tiszaháti térségben - a fehérgyarmati kistérségben - a legfőbb erőforrás ma is a mezőgazdaság. Az önkormányzatok gyakran erejükön felül tartják fenn a kistérség településeiben a szociális földprogramot, és a nemzeti támogatások mellett uniós forrásokra is sikerrel pályáznak. Az ország másik végén, a Zalaszentgróti kistérségben ${ }^{16}$ elhelyezkedő Sümegcsehin Sümeg és a Veszprém megyei bányák közelsége a sikeresség egyik tényezője (SzÉKELY GY. 2006).

A harmadik nagyobb sikerességi faktorcsoport a falvak esetébe is csak az 1990-es évek óta kap hangsúlyos szerepet, mely szerint a települési siker hátterében az önkormányzatok állnak. Az 1990-es évek kutatásaiban is megfigyelhető volt már az a megállapítás, hogy a falvak fejlődése a helyi közösségen, a választott testületen múlik (CSAPÓ T. 1993), és a település sikere az önkormányzat (polgármester, képviselőtestület) sikerét jelenti. Nehezíti a helyzetet, hogy a települési vezetők esetenként kicserélődnek, egy korábbi sikert ígérő kezdeményezés csak az utódok idején valósul meg (TÁLl É. 2000).

Az 1980-as évek sokat publikált fejlődést segítő tényezője a fiatalok helyben tartása volt. E szerint azokban az aprófalvakban van (volt) meg a remény a túlélésre, ahol fiatalok vannak, és ahol a helyi, egyedi lehetőségeket felismerik (ENYEDI GY. 1984, CSATÁRI B. 1993). Napjainkban a népesség helyben tartása mellett lakossági aktivitás és az egyedi adottság fontossága jelentkezik a fejlődést előidéző tényezők között, mely összekapcsolódik az idősgondozás, gyermekfelügyelet megoldottságával is. Az ehhez szükséges civil szervezetek megléte is elengedhetetlen egy település, akár egy aprófalu sikerességéhez, annak okán, hogy mindez segítheti a foglalkozásbővítést az adott településen (TIMÁr J. 2007). A lakossági aktivitás ösztönzéséhez hozzájárulhat egy vagy több személy, aki(k) magára vállalja(ják) a település érdekeinek képviseletét, tehát szükséges egy véleményformáló réteg, az adott falu egyediségének felismerése, együttmüködés a település lakosai között (BóDI F. 2000, DURÓ A. 2012).

A falu fejlődéséhez a lakosság mellett a polgármester személye is nagyban hozzájárul. Az 1990-es évektől merült fel egy falu fejlődése szempontjából az ambiciózus, rátermett, változást, fejlődést akaró vezető szükségessége és annak a

\footnotetext{
${ }^{16}$ A helyi adottságok megléte mellett fontos említést tenni a Sümegcsehin negyven évig a helyén maradó iskolaigazgató, és egyházi vezető tenni akarásáról is.
} 
mozgásterének problematikája, hiszen a polgármesternek egyszerre kell „,polgárnak és mesternek" lennie (BöHM A. 1993). A Tornai medence sikertelepülése Hidvégardó esetében is jelentős szerep jut a polgármesternek, az ő széleskörű kapcsolati hálójának és a település vezetőjét támogató, tenni akaró rétegnek (SzÉKELY GY. 2006). De Soltvadkert esetében is nagy szerep jut a helyben formálódó kulturális tőke felhalmozódásának, a diplomás vállalkozói réteg - „diplomás farmerek” - jelenléte hozzájárul a falu sikerességéhez ${ }^{17}$ (FERTŐ I. - LÉNÁRT ZS. - MAURER GY. - WINKLER T. 1990). Szintén a helyi társadalom szerepvállalásához köthető a foglalkoztatási programokban rejlő lehetőségek kiaknázása, hiszen mindez egy felkészült helyi vezető réteget feltételez (G. FEKETE É. 2001). Gondoljuk csak át, hogy az elmúlt években az aprófalvak többségében nem indult kellő számú foglalkoztatási program, vagy ahol indult, ott munkaerőhiány adódott. A foglalkoztatási programok nyújtotta lehetőségek hatékony felhasználása ugyanis csak a helyi társadalom szerepvállalásával megoldható.

Általánosságban a sikeresség tényezőiről elmondható, hogy a vizsgálatok leginkább versenyszemléletü megközelítésüek, gazdasági oldalról fordulnak a sikeresség felé, a nemzetközi és a hazai szakirodalomban is. Az 1990-es évek után fordul a szakma figyelme a társadalmi értékek felé (külföldön már hamarabb), a városi sikerességet mérő és a falvak fejlődését vizsgáló kutatásokban is, úgy, hogy a versenyszemlélet továbbra is meghatározó marad. Kevésbé kutatott a települések fejlődésének kérdését illetően a falvak lakóinak véleménye azokban az esetekben, amikor nem az „Ön szerint is sikeres...” típusú megközelítést alkalmazza a kutató. Elmondható továbbá, hogy a sikeresség tényezői a városokban is, és a falvakban is gyorsan módosulnak. Míg a városok sikeressége esetében a szakirodalom szolgáltat komplex definíciót, és egy viszonylag jól lehatárolható tényezőcsoportot a sikerességre vonatkozóan, addig a falvak esetében komplex sikeresség fogalom nem fellelhető, a fejlődést eredmémyezők közül is csak kevés kerül megnevezésre.

Disszertációmban ezért törekszem arra, hogy ne csupán egy-egy sikertényezőt adjak meg az aprófalusi sikerességgel kapcsolatban, hanem egy komplex tényezőcsoportot határoljak le az aprófalvak sikerességére vonatkozóan, statisztikai elemzésre, empirikus, és terepi eredményeikre támaszkodva. Továbbá törekszem arra is, hogy a kutatás során lehatárolt sikerességi tényezők alapján egy sikeres aprófalu modell is megadható legyen.

\footnotetext{
${ }^{17}$ Soltvadkert a feldolgozott cikk íródásának idején még nagyközségi jogállású település volt, ezen oknál fogva említjük a 'Falvak sikeressége' részben.
} 


\section{AZ APRÓFALVAK SIKERESSÉGI TÉNYEZŐI „KÍVÜLRŐL”SZEMLÉLVE}

\subsection{A vizsgálatba vont falvak helyzete az aprófalvak között}

Annak érdekében, hogy a falvak sikerességi tényezői minél pontosabban megadhatók legyenek, több értékrend mentén mértem a sikert. Egyik ezek közül a statisztikai sikeresség, fejlettség felállítása volt az aprófalvak között. Az aprófalvak fejlettségének elemzése során egyrészt arra törekedtem, hogy az aprófalvas településállomány egészére vonatkozóan adjak információkat, másrészt annak bemutatására, hogy a vizsgálatba vont falvak közül a magas fejlettséggel rendelkezők milyen faktoroknak köszönhetik a sikerességüket. A vizsgálatba vont települések összfejlettségi adatait az aprófalvakéval összevetve az alábbi megállapítások tehetők. A módszertani részben leírtak alapján a településállományból leválogatott 1073 aprófalu közül a legmagasabb összfejlettségi pontszámmal rendelkező felső 10\%-ban szerepel a vizsgálatba vont falvak közül 10 (sorrendben: 1. Szántód, 15. Dunaszentmiklós, 29. Fertőhomok, 38. Hegymagas, 42. Gosztola, 43. Dozmat, 45. Dörgicse, 65. Csonkahegyhát, 75. Villánykövesd, 99. Tivadar). A legmagasabb összfejlettséggel rendelkező települések felső 15\%-ában szerepel továbbá a 122. Apátistvánfalva, a 134. Velemér és a 173. Romonya. A felső egyharmad határán található a 314. Klárafalva és a 360. Alsómocsolád, míg a 725. Fony a legalacsonyabb összfejlettséggel rendelkező alsó egyharmad határán található. Az aprófalvak statisztikai vizsgálata alapján a korábbi szakirodalmakban sikeresnek, fejlettnek nevezett aprófalvaknak tehát csak 2/3-a rendelkezik olyan tényezőkkel ma is, melyek alapján magas összfejlettségi pontszámot értek el. A kérdés a továbbiakban az, hogy a fejlett aprófalvak hol helyezkednek el, illetve, hogy az egyes mutatócsoportokon belül mely tényezők eredményeznek magas fejlettségi értéket.

$\mathrm{Az}$ összfejlettség térbeliségét tekintve (2. ábra) a Balaton vonalától északnyugatra és délkeletre, két részre osztható az ország. Az északnyugati országrészben a két legmagasabb fejlettségi értékkel jellemezhető kategória települései fordulnak elő nagy számban, legmagasabbak az értékek a Balaton térségében és az osztrák határ menti területeken (Köszegi és Szombathelyi kistérség). Magas koncentráció figyelhető meg továbbá a Zalaegerszegi és az Öriszentpéteri kistérség területén. A Balaton vonalától keletre eső országrészben elszórtan található egy-egy fejlett település, mint például a turisztikai vonzerővel és magas vendégéjszaka számmal 
rendelkező Jósvafő és Hollókő, vagy a jó közlekedés-földrajzi helyzetű Zengővárkony, illetve a szintén jó idegenforgalmi, közlekedési helyzetü, nemzetiségi falu, Villánykövesd. A legrosszabb összfejlettségű települések összefüggő tömbben jelennek meg Borsod-Abaúj-Zemplén és Baranya megyében, amit korábbi kutatások is alátámasztanak (G. FEKETE É. 2001). A déli országrészben a Sásdi, Siklósi és Sellyei kistérség településeinek helyzete összfejlettségi szempontból a legkedvezötlenebb. Északkelet-Magyarországon, zárt tömbben helyezkedik el a legfejletlenebb 20 település közel fele. Több fejlettségi tényező együttes jelenléte, dinamikus térségek kialakulása tehát leginkább a Balaton vonalától északnyugatra jellemző.

Hogy pontosan mely tényezők eredményezik egy-egy vizsgálatba vont falu sikerességét, magas összfejlettségi értékét, annak eldöntésére a mutatócsoportokat külön-külön elemeztem. A statisztikai vizsgálat során felállított sikeresség alapján vagyis, hogy egy adott skálán melyik falu hol foglal helyet - határoltam le a statisztikailag megadható sikerességi tényezők körét, az alábbiak szerint. A mutatócsoportokon és összfejlettségen belüli magas értékeket és jó helyezéseket $(\mathrm{H})$ a mutatócsoportok vizsgálata alapján az alábbi okok eredményezik (1. táblázat):

- Szántód, Dozmat, Gosztola, Fertőhomok, Romonya és Dunaszentmiklós települések népesség mutatócsoporton belüli első 100 legmagasabb értékkel rendelkező aprófalva közé kerülését más-más okok idézik elő. Szántód esetében a Balaton közelsége magas vándorlási nyereséget eredményez, és szintén magas vándorlási nyereséggel bír Fertőhomok és Dunaszentmiklós is. Dozmat és Romonya települések lakópark építései növelik meg ennek a mutatócsoportnak az értékét, az 52 fős Gosztola esetében a 2010-es választások előtt betelepült lakosság járul hozzá a magas mutatócsoporton belüli értékhez.

- A társadalom mutatócsoport legmagasabb értékekkel rendelkező 100 aprófalva közé kerülő Apátistvánfalva, Dunaszentmiklós és Fertőhomok (7. kép - 8. sz. melléklet) szlovén, német és horvát nemzetiségi lakosságának magas aránya eredményezi e mutatócsoport élére kerülését. Megjegyzendő azonban, hogy a német nemzetiségü Villánykövesd nem került be a 100 legjobb település közé, mivel a civil szerveződések száma alacsony, és a lakosság iskolázottsága is elmarad az első 100 település átlagától. Gosztolán kimagasló a civil szervezetek, az érettségivel és diplomával rendelkezők aránya. Szántódon magas az érettségivel rendelkező lakosság aránya, Csonkahegyháton a civil szervezetek aránya eredményezi a mutatócsoporton belüli első 100 település közti helyzetet. 


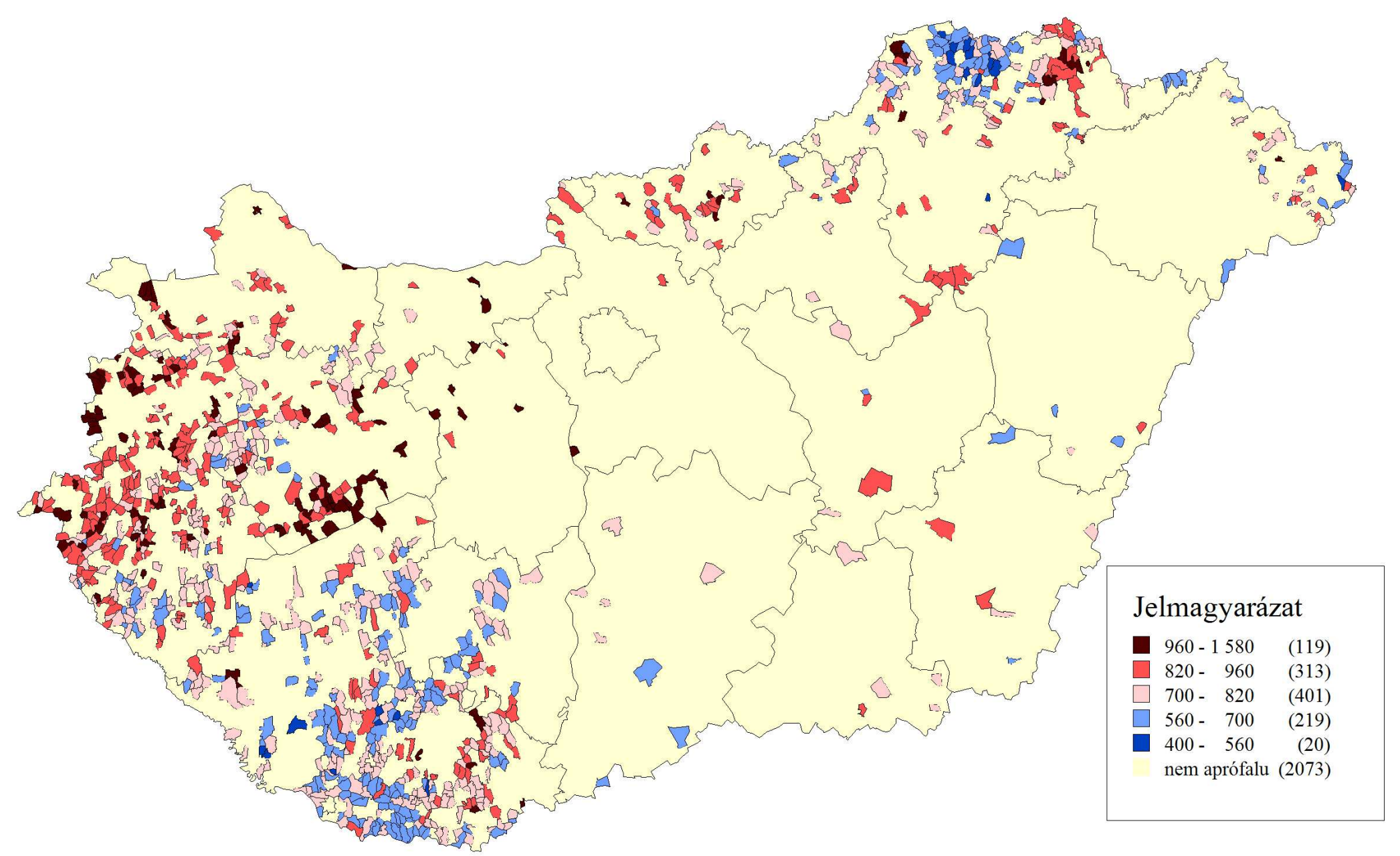

2. ábra. Az aprófalvak fejlettsége (Forrás: saját szerkesztés) 
- Szántód ellátottságbeli helyzete az összes aprófalun belül legelőre helyezi a települést. A falu ellátottságát jellemző kedvező értékeket már korábbi vizsgálatok is igazolták (BALOGH A. 2008, KISS J. P. 2008). A falu vonalas infrastruktúrája, alapfokú intézményi ellátottsága kiváló, azon kevés aprófalvak egyike az országban ahol benzinkút működik. A legjobb ellátottságbeli értékekkel rendelkező 100 aprófalu közé került Dörgicse, Dunaszentmiklós, Hegymagas és Fertőhomok, melyek a 100 legjobb település átlagát meghaladó csatornázottsági értékkel rendelkeznek, Fertőhomokon és Dunaszentmiklóson a vezetékes gázzal való ellátottság értékei is magasak. Csonkahegyhát internet és alapfokú intézményi ellátottságával került a legjobban ellátott falvak közé.

- A gazdaság mutatócsoportot tekintve a vizsgálatba vont településeket több aprófalu megelőzi, melyet korábbi vizsgálatok is igazoltak (BAJMÓcY P. - JóZSA K. - PÓCSI G. 2007). Bár Szántód, Fertőhomok, Gosztola, Velemér, Dunaszentmiklós az első 100 település közé kerültek, Szántód kivételével az első 100 falu második felében találhatók. Fertőhomokon, Dunaszentmiklóson és Gosztolán nincs szociális segélyben részesített lakos, utóbbi településen az SZJA érték is magas. Szántódon és Veleméren pedig mind a szociális segélyben részesítettek, mind az álláskeresők aránya jóval az első 100 település átlaga alatt van.

- Dozmat és Dunaszentmiklós esetében a közlekedés mutatócsoporton belüli első 100 legjobb falu közé kerülést a kistérségi központ és a megyeközpont jó út és időtávolsági adatai okozzák, mely mutatók értékei évtizedek óta hangsúlyosak a fejlődést előidéző tényezők között (ERDÖsı F. 1984). Csonkahegyhát és Romonya esetében a kistérségi központba induló tömegközlekedési járatszám értékek is magasak, Szántódon az aprófalvak átlagához viszonyítva magas az egy főre jutó személygépkocsik aránya. Az eddigi mutatócsoportokban az első 100 település közé nem került Klárafalva közlekedési mutatócsoporton belüli előnyös helyzetét a jó tömegközlekedési adatainak köszönheti (11. kép - 8. sz. melléklet).

- Szántód és Tivadar esetében a vízközelség és az ebböl adódó magas vendégéjszakák száma okozza az első 100 település közé jutást az idegenforgalom mutatócsoporton belül. Szintén a vendégéjszakák száma a döntő fontosságú Gosztola és Dunaszentmiklós esetében. Dörgicse, Velemér (15. kép - 8. sz. melléklet) és Villánykövesd épített öröksége, idegenforgalmi adottsága eredményezi a mutatócsoporton belüli jó helyezést, Hegymagas esetében a 
kimagasló értékekhez a relatíve magas kulturális rendezvényeken résztvevők száma járul hozzá nagymértékben.

\begin{tabular}{|c|c|c|c|c|c|c|c|c|c|c|c|c|c|c|}
\hline Településnév & $\begin{array}{c}\text { Népes- } \\
\text { ség }\end{array}$ & $\mathbf{H}$ & $\begin{array}{l}\text { Társa- } \\
\text { dalom }\end{array}$ & H & \begin{tabular}{c|} 
Ellá- \\
tottság
\end{tabular} & $\mathbf{H}$ & $\begin{array}{c}\text { Gazda- } \\
\text { ság } \\
\end{array}$ & $\mathbf{H}$ & \begin{tabular}{c|}
$\begin{array}{c}\text { Közle- } \\
\text { kedés }\end{array}$ \\
\end{tabular} & H & $\begin{array}{c}\text { Idegen- } \\
\text { forgalom }\end{array}$ & H & $\begin{array}{c}\text { Összfej- } \\
\text { lettség }\end{array}$ & H \\
\hline Szántód & 317,13 & 9. & 143,18 & 16. & 356,35 & 1. & 270,62 & 30. & 205,62 & 52. & 277,73 & 4. & 1570,63 & 1 \\
\hline Dunaszentmiklós & 248,50 & 100. & 119,66 & 30. & 213,68 & 90. & 255,11 & 94. & 203,87 & 60. & 116,07 & 64. & 1156,89 & 15 \\
\hline Fertőhomok & 275,70 & 38. & 117,11 & 33. & 221,44 & 67. & 259,67 & 59. & 169,27 & 502. & 39,69 & 282. & 1082,88 & 29 \\
\hline Hegymagas & 234,42 & 166. & 84,40 & 107. & 235,30 & 45 . & 231,17 & 320. & 186,70 & 223. & 94,09 & 90. & 1066,08 & 38 \\
\hline Gosztola & 284,04 & 32 . & 153,38 & 12. & 55,47 & 1042. & 257,93 & 70. & 178,36 & 351. & 127,60 & 48. & 1056,78 & 42 \\
\hline Dozmat & 306,81 & 18. & 69,82 & 183. & 202,12 & 128. & 239,75 & 225. & 225,85 & 6. & 11,82 & 837. & 1056,16 & 43 \\
\hline Dörgicse & 241,26 & 130. & 76,54 & 134. & 218,24 & 79. & 235,98 & 273. & 170,26 & 488. & 112,45 & 69. & 1054,72 & 45 \\
\hline Csonkahe & 243,77 & 116. & 86,13 & 96. & 218,60 & 78 & 253,25 & 105. & 201,06 & 75. & 24,97 & 534. & 1027,78 & 65 \\
\hline Villánykövesd & 188,83 & 760. & 60,93 & 265. & 201,30 & 133. & 244,61 & 186. & 180,88 & 300. & 136,78 & 42. & 1013,33 & 75 \\
\hline Tivadar & 191,91 & 702. & 59,53 & 278. & 155,43 & 431. & 193,41 & 678. & 142,82 & 882. & 240,00 & 9. & 983,10 & 99 \\
\hline Apátistv & 208,67 & 408. & 156,02 & 9. & 157,44 & 409 . & 237,56 & 251. & 167,90 & 532. & 30,18 & 420. & 957,78 & 122 \\
\hline Velemér & 173,64 & 934. & 84,50 & 106. & 121,74 & 716. & 255,46 & 87. & 154,68 & 745. & 160,80 & 26. & 950,84 & 134 \\
\hline Romonya & 262,06 & 56. & 65,20 & 226. & 131,07 & 639. & 237,76 & 249. & 212,97 & 25. & 14,61 & 786. & 923,67 & 173 \\
\hline Klárafalva & 228,67 & 208. & 35,33 & 717. & 183,07 & 232. & 204,30 & 582. & 200,64 & 77. & 9,21 & 924. & 861,23 & 314 \\
\hline Alsómocsolád & 215,19 & 335. & 50,11 & 403. & 162,44 & 369. & 206,63 & 555. & 133,62 & 964. & 77,36 & 109. & 845,34 & 360 \\
\hline Fony & 207,64 & 428. & 82,83 & 111. & 110,69 & 808. & 165,33 & 855. & 148,10 & 826. & 22,81 & 575. & 737,41 & 725 \\
\hline
\end{tabular}

1. táblázat. A vizsgálatba vont települések mutatócsoportonkénti és összfejlettsége az aprófalvas településállományban

(Forrás saját számítás alapján saját szerkesztés)

Az aprófalvak statisztikai vizsgálata alapján az összfejlettségen belüli magas értékeket eredményező mutatók ismeretében az aprófalvak sikerességi tényezői az alábbiakban összegezhetők:

1. A korábbi statisztikai lehatárolások és az aprófalvakra vonatkozó jelen vizsgálat összevetése kijelölte azoknak a sikerességi tényezőknek a körét, amelyek minden esetben a sikeresség, fejlődés előremozdítói az adott településen. Így aprófalvas statisztikai vizsgálatom megerősítette Szántód esetében a Balaton közelséget, megerősítette továbbá, hogy a kis településméret kevés számú népességmozgása is nagymértékben javíthatja a település helyzetét. Hangsúlyosnak találom továbbá nemzetiségek jelenlétét a településen (a vizsgált aprófalvakban ez a horvát, szlovén és német nemzetiségek esetében igazolódott), márcsak azért is, mivel az aprófalvas vizsgálat során e nemzetiségek jelenléte a faluban és az iskolai végzettség értékek szoros korrelációt mutattak. A falut jellemző magas vendégéjszaka szám és turisztikai attrakció együttes jenléte a sikeresség tényezője lehet, csakúgy, mint a település szuburbán volta (lakásállomány növeléssel, akár lakópark létesítéssel).

2. A korábbi sikerességi faktorok másik részének fejlődést eredményező voltát a települések egy részében megerősítette az aprófalvas statisztikai vizsgálat, másik részükben nem egyértelmüsítette sikerességi tényező szerepüket. Ilyen, nem minden település esetében egyértelmű sikerességi tényezőnek bizonyult a határ menti helyzet, az épített örökség jelenléte a településen, a falu központi szerepkör jellege, illetve a jó közlekedés-földrajzi helyzet. 
3. További fejlődést előremozdító, korábbi statisztikai vizsgálatokban nem hangsúlyozott mutatónak tekintem az aprófalvas statisztikai vizsgálat eredményei alapján a vándorlási nyereséget, a civil szervezetek magas arányát, a település lakosainak magas fokú iskolázottságát, a településen élő alacsony számú segélyezettet és alacsony számú álláskeresőt. Szintén fejlődést segítő tényező a kistérségi és megyeközpont jó közúti és időtávolsági elérhetősége mellett a felsőrendű úthoz való közelség, az alapfokú intézményi ellátottság megléte, a vonalas infrastruktúrák közül a csatornázottság, vezetékes gázzal való ellátottság és internet elérés magas értékei.

Az aprófalvak statisztikai vizsgálata alátámasztja az elméleti részben közölt azon megállapításokat, melyek szerint egyrészt a sikerességi tényezők folyamatosan változnak, másrészt azt is, hogy több tényező együttes jelenléte, egyfajta komplexivitás szükséges a települési sikeresség, fejlődés megvalósulásához.

A faluállomány aprófalvaiban végzett statisztikai vizsgálat kapcsán két sajátos helyzetü csoportról mindenképp említést kell tenni. A népességszámukat veszítő falvakról, azok statisztikai jellemzőiröl korábbi vizsgálatomban is tettem már említést (BAJMÓcy P. - JózsA K. - PóCsi G. 2007). Az 1990-es évben még 500 fő feletti népességszámmal rendelkező, de mára az aprófalvak kategóriájába ,belefogyott" falvak összfejlettségi értékeik tekintetében nem térnek el nagyban az aprófalvak átlagától. Ez a 99 település döntően az aprófalvak összfejlettségi listájának várttól eltérően nem az utolsó, hanem a lista középső egyharmadában található, sőt együttes összfejlettségi értékük átlaga $(802,12)$ gyakorlatilag megegyezik az aprófalvak egészének összfejlettségi átlagával $(802,14)$.

Ennek oka többes, egyrészt a népességszámukat vesztett települések ellátottsági, gazdasági mutatói döntően nem rosszabbak az aprófalvak átlagától másrészt társadalmi, idegenforgalmi mutatóik értékei viszont összességében elmaradnak azoktól. Ez a kettősség eredményezi azt, hogy a legjobb aprófalvaktól már alacsonyabb, a legrosszabb aprófalvaktól pedig még magasabb adatokkal jellemezhetők. Mindezek mellett a településméretük is befolyásoló tényező, melynek magasabb ellátottsági és gazdasági értékeit korábbi kutatások is igazolták (BAJMÓCY P. - BALOGH A. 2002).

Az aprófalu kategóriájába „belefogyott” települések között találunk azonban kevés számú, nyolc olyan települést is, amelyek a legjobb összfejlettségi értékekkel rendelkező aprófalvak között vannak. A kutatás szempontjából hasznosnak tartom ennek a nyolc településnek a vizsgálatát is. Róluk elmondható, hogy a többi falutól 
eltérő magas fejlettségi értékeiket nemzetiségi lakosságuk, Balaton közelségük és jó közlekedési helyzetük eredményezi.

Mindezt néhány példával alátámasztva a nyolc falu közül pl. Füzér társadalmi mutatócsoportjának értéke 84,62, ami csaknem kétszerese az aprófalvak társadalmi mutatócsoportja átlagának $(48,9)$. Ezt a magas értéket a nemzetiségi jelenlét mellett a civil szervezetek magas száma eredményezi. Az aprófalu kategóriába belefogyott nyolc település egyike Balatonszepezd is. A település idegenforgalmi mutatócsoportjának értéke $(288,5)$ járul hozzá a magas összfejlettségi pontszámhoz. A teljes aprófalvas állomány idegenforgalmi mutatócsoportjának átlaga ezzel szemben 36,43.

Kutatásom fö kérdéseire keresve a választ fontosabb talán azoknak az aprófalvaknak a vizsgálata, amelyek 1990-ben még aprófalvak voltak, mára azonban már nem tartoznak ebbe a településkategóriába, vagyis ,kinőttek” az aprófalvak kategóriájából. Ez 35 települést jelent, érintve a vizsgálatba vont falvakat is. A vizsgálatba vont falvak közül ugyanis három (Szántód, Fertőhomok és Klárafalva) növelte népességét 500 fő fölé 2010-re. Összfejlettségi értéke mindhárom településnek (Szántód - 1570,63; Fertőhomok - 1082,88; Klárafalva - 861,28) magasabb az összes aprófalu összfejlettségi értékének átlagától $(802,14)$. Ha a 35, aprófalu kategóriájából kinőtt falu összfejlettségi átlagát tekintjük $(945,32)$, akkor viszont szembetűnő Szántód és Fertőhomok fejlettsége, és Klárafalva adatainak ezen átlagtól való elmaradása. Érdemes ezért az aprófalvak kategóriájából „kinőtt” falvakat mutatócsoportonként is vizsgálni, a sikerességi tényezők állandóságának kérdését szem elött tartva.

Szántód és Fertőhomok a népességüket növelő, magas összfejlettségi pontszámmal rendelkező települések közé tartoznak - Szántód magas idegenforgalmi pontértékeit korábbi vizsgálatomban is igazoltam (BAJMÓCY P. - JÓZSA K. 2008). Ebbe a csoportba tartozik Szántód mellett még többek között Paloznak (idegenforgalmi mutatócsoportjának értéke 170,77), vagy Várgesztes (idegenforgalmi mutatócsoportjának értéke 140,46) is. Az aprófalvak idegenforgalmi mutatócsoportjának átlaga $(36,43)$ a fent említett adatoktól jelentősen elmarad. Másrészt olyan falvak találhatók az aprófalvak kategóriájából „kinőtt” falvak között, amelyek jó közlekedési, gazdasági, társadalmi mutatókkal jellemezhetők. Így pl. Söréd gazdaság mutatócsoportjában mutat magas értéket $(253,86)$, miközben az aprófalvak gazdaság mutatócsoportjának átlagértéke 201,03. A vizsgálatba vont Fertőhomok társadalmi mutatócsoportjának értéke $(117,11)$ és Cserkút társadalmi mutatócsoportjának értéke $(96,83)$ is jóval az aprófalvak társadalom mutatócsoportjának átlagértéke $(48,9)$ fölötti. 
Igazolható azonban az is, hogy a növekvő népességszám nem jelent minden esetben fejlődő települést. Növekvő népességszám melletti relatív fejletlenségről is beszámolt már a szakirodalom (BAJMÓCY P. — BOROS L. 2004). A vizsgálatba vont falvak közül Klárafalva a népességét növelő, de csak az aprófalvak fejlettségi pontszámának átlagát éppen meghaladó pontszámmal rendelkező település, de a népességét szintén növelö Kispalád és Tiszavid összfejlettsége viszont jóval az aprófalvak fejlettségi pontszáma alatti. A Kispaládhoz és Tiszavidhez hasonló statisztikai adatokkal jellemezhető, népességszámukat növelő falvak leginkább társadalmi mutatócsoportjuk (Klárafalva - 35,33, Kispalád - 18,63, Tiszavid - 32,07) értékében maradnak el az aprófalvak átlagától. Az iskolázottsági adatok alacsonyak, a segélyezettek száma magas. De az utóbbi két település esetében a gazdasági, ellátottsági, közlekedési mutatók is jóval átlag alattiak.

Ez utóbbi csoport, vagyis a népességszámukat növelő falvakra két okból tartom fontosnak felhívni a figyelmet. Egyrészt azt kell hangsúlyozni, hogy azok az aprófalvak, amelyek növelik népességüket, így elöbb-utóbb kiesnek az aprófalu kategóriájából, sikeresnek abban az esetben nevezhetők, ha társadalmi, ellátottságbeli, gazdasági, közlekedési (idegenforgalmi attrakcióval rendelkezés esetén idegenforgalmi) mutatóik tekintetében is magas értékekkel jellemezhetők. A fentebb felsorolt mutatócsoportok közül egy-két mutató magas értéke és a település népességének növekedése önmagában nem eredményezi a település sikerességét.

Másrészt az aprófalvak népességszám szerinti elkülönítése is problémát okoz. A fogalmi keretek részben lehatárolt aprófalu definíció szerint az aprófalu 500 főnél nem népesebb települést jelent. Depresszivitás tekintetében ez a települési csoport vizsgálható, hiszen az „aprófalvas szindróma” egyik jellemző tünete éppen a településről való elvándorlás, vagyis a népességszám csökkenése. A dinamikus aprófalvak vizsgálata viszont éppen azért ütközik nehézségbe, mert a népességszámuk nő (fiatalok helyben maradásával, beköltözéssel), és ezáltal kiesnek az aprófalu kategóriából. Ez a tény, valamint az aprófalvak statisztikai helyzetének teljes faluállományon belüli feltáratlansága indokolja a teljes faluállomány statisztikai vizsgálatát. 


\subsection{A vizsgálatba vont falvak helye összfejlettségi adataik alapján az összes falu} között

Annak eldöntése érdekében, hogy a vizsgálatba vont falvak statisztikai fejlettsége csak az aprófalvak között áll-e fenn, vagy a teljes faluállományon belül is a fejlettebb falvak közé tartoznak, statisztikai vizsgálatomat kiterjesztettem Magyarország 2935 falvára $^{18}$. A vizsgálatba vont települések összfejlettségi adatait a teljes faluállomány összfejlettségi adataival összevetve az alábbi megállapítások tehetők. A fent leírtak alapján a településállományból leválogatott 2935 falu közül a legmagasabb összfejlettségi pontszámmal rendelkező felső 10\%-ban szerepel a vizsgálatba vont falvak közül 7 (sorrendben: 1. Szántód, 99. Dunaszentmiklós, 206. Fertőhomok, 253. Hegymagas, 279. Gosztola, 282. Dozmat, 288. Dörgicse). A legmagasabb összfejlettséggel rendelkező települések felső 15\%-ában szerepel továbbá a 386. Csonkahegyhát. A felső egyharmadban található a 451. Villánykövesd, a 616. Tivadar, a 766. Apátistvánfalva és a 807. Velemér. A középső egyharmadban az 1024. Romonya, az 1571. Klárafalva és az 1727. Alsómocsolád, az alsó egyharmadban a 2503. Fony helyezkedik el. Ezeket a helyezéseket az aprófalvak közti helyezésekkel összevetve elmondható, hogy Szántód, Dunaszentmiklós, Fertőhomok, Hegymagas, Gosztola, Dozmat, Dörgicse és Csonkahegyhát fejlettsége nem csupán az aprófalvak, hanem a teljes faluállomány tagjai között a legmagasabb pontértékekkel jellemezhető. Villánykövesd, Tivadar, Apátistvánfalva, Velemér és Romonya az aprófalvak között tartoznak a fejlettebb települések közé, a teljes faluállományt tekintve helyezéseik szerint kikerülnek az első 15\% legfejlettebb település kategóriájából, mint ahogy további pozíciót veszít a már aprófalvak között is fejletlenebbnek számító Klárafalva, Alsómocsolád és Fony is. Vagyis a teljes faluállományt érintő vizsgálat is azt a feltevésemet igazolja, mely szerint több tényező együttes jelenléte szükséges a siker, fejlődés eléréséhez. A vizsgálatba vont falvak közül azok rendelkeznek a teljes faluállomány tekintetében is a legmagasabb pontértékekkel, amelyek több mutatócsoporton belül elért magas fejlettségi értékkel jellemezhetők.

Mivel a hazai és a nemzetközi szakirodalomban az aprófalvas településállomány teljes faluállományon belïli fejlettségi helyzetére vonatkozó kutatás eddig nem

\footnotetext{
${ }^{18}$ A magyarországi falvak lehatárolásánál nem a KSH által meghatározott községi, illetve városi jogállást vettem alapul, hanem a Beluszky Pál által felállított városhierarchia rendszerébe (fővárostól a városi szerepkör nélküli városi rangú településekkel bezáróan) nem került településeket (falvakat) (BELUSZKY P. - GYŐRI R. 2006).
} 
zajlott, így doktori dolgozatomban röviden erre vonatkozóan is kívánok néhány megállapítást tenni (2. táblázat). Az összfejlettséget tekintve az aprófalvak fejlettségi átlaga $(802,06)$ elmarad a teljes faluállomány fejlettségi átlagától $(879,40)$. Amennyiben az aprófalvak fejlettségi átlagértékét az aprófalvak fejlettségi értékei közé helyezem, az átlag fejlettségi érték 2076., ugyanezen módszer szerint a teljes faluállomány fejlettségi átlaga 1412. helyezést eredményezne a faluállomány fejlettségi értékei között. Amennyiben a fejlettségi adatokat mutatócsoportonkénti bontásban vizsgálom, az aprófalvak mutatócsoportonkénti átlagértékei és a teljes faluállomány mutatócsoportonkénti átlagértékei között érdemi eltérések a társadalmi vonatkozások és ellátottság terén mutathatók ki.

\begin{tabular}{|c|c|c|r|r|r|r|r|}
\cline { 2 - 8 } \multicolumn{1}{c|}{} & $\begin{array}{c}\text { Népes- } \\
\text { ség }\end{array}$ & $\begin{array}{c}\text { Társada- } \\
\text { lom }\end{array}$ & $\begin{array}{c}\text { Ellátott- } \\
\text { ság }\end{array}$ & Gazdaság & $\begin{array}{c}\text { Közleke- } \\
\text { dés }\end{array}$ & $\begin{array}{c}\text { Idegenfor- } \\
\text { galom }\end{array}$ & $\begin{array}{c}\text { Összfej- } \\
\text { lettség }\end{array}$ \\
\hline Összes falu átlaga (Öf) & 215,75 & 56,36 & 188,64 & 209,93 & 173,33 & 35,39 & 879,40 \\
\hline $\begin{array}{c}\text { Falvak átlaga aprófalvak } \\
\text { nélkül (F-aprófalvak) }\end{array}$ & 221,60 & 60,65 & 213,77 & 215,04 & 177,90 & 34,73 & 923,69 \\
\hline Aprófalvak átlaga & 205,43 & 48,92 & 144,90 & 201,03 & 165,35 & 36,43 & 802,06 \\
\hline $\begin{array}{c}\text { (Öf) helyezése az összes } \\
\text { falu értékei között }\end{array}$ & 1254. & 1182. & 1553. & 1695. & 1504. & 951. & 1412. \\
\hline $\begin{array}{c}\text { (F-aprófalvak) helyezése } \\
\text { az aprófalvak nélküli } \\
\text { falvak értékei között }\end{array}$ & 977. & 981. & 1048. & 1549. & 1285. & 981. & 1742. \\
\hline $\begin{array}{c}\text { Aprófalvak átlagának } \\
\text { helyezése az aprófalvak } \\
\text { értékei között }\end{array}$ & 1785. & 1626. & 2285. & 1920. & 1854. & 898. & 2076. \\
\hline
\end{tabular}

2. táblázat. Az összes falu, az 500 fö feletti települések és az aprófalvak mutatócsoportonkénti fejlettségi átlagai, valamint az átlagok helyezései (Forrás: saját számítás alapján saját szerkesztés)

Ha a teljes faluállományból kiveszem az aprófalvak értékeit és az aprófalu nélküli faluállomány mutatócsoportonkénti átlagértékeit viszonyítom az aprófalvak mutatócsoportonkénti átlagértékéhez, továbbra is a társadalom és az ellátottság mutatócsoportok értékeiben található érdemi különbség. Ez az eltérés a közlekedés és a népesség mutatócsoportok esetében is kimutatható, különösen, ha a helyezési értékeket tekintem. A társadalom és ellátottság mutatócsoportok átlagértékeinek helyezését a teljes faluállományon belüli mutatócsoportonkénti helyezésekkel együtt figyelembe véve előbbi megállapításaim szintén alátámaszthatók.

A mutatócsoportok adatait tovább bontva mutatókra, az a megállapítás tehető, hogy a társadalmi mutatócsoporton belül az iskolai végzettség járul hozzá (pontosabban annak hiánya) az aprófalvak alacsonyabb értékeihez, a nemzetiségi arány és a civil 
szerveződés mértéke nem különbözik sokban az aprófalvakban és az 500 főnél népesebb települések csoportjában. Az ellátottság mutatócsoporton belül az (elmúlt években bezárt) alapfokú intézmények hiánya okozza az eltérést. Vonalas infrastruktúra tekintetében az aprófalvak összességében nincsenek döntően rosszabb helyzetben, mint a teljes faluállomány. Az idegenforgalmi mutatócsoport az egyetlen, ahol az aprófalvak jobb fejlettségi értékkel rendelkeznek, mint a teljes faluállomány (különösen az 500 fő feletti falvak). A vonzerő és az eltöltött vendégéjszaka szám tekintetében is megelőzik 500 főnél népesebb társaikat, az idegenforgalmi vonzerő magas értékét az aprófalvakban korábbi kutatásomban igazoltam (JózSA K. 2008).

A fejlett aprófalvak térbeli elhelyezkedését és a fejlett falvak térbeli elhelyezkedését tekintve egyezőségek és különbségek is kimutathatók. Az összfejlettség térbeliségét tekintve (3. ábra) a teljes faluállománynál is kulcsfontosságú a Balaton vonala, mely az M7-es autópálya Budapestig tartó szakaszával, az M0-s körgyürüvel, az M7-es autópálya és az M3-as autópálya vonalával kijelöli a legfejlettebb falvak helyét az országban. Fejlett falvakat találunk az apófalvas statisztikai vizsgálathoz hasonlóan az osztrák határ mentén is. A teljes faluállomány fejlettségi statisztikai vizsgálatánál kirajzolódik a városok környékének fejlettsége, olyan az aprófalvas vizsgálatnál relatív fejletlen területeken is, mint pl. Pécs, Gyöngyös, vagy Eger környéke. A Pécs környéki Orfü, Magyarszék és Pogány idegenforgalmi és közlekedés-földrajzi helyzete miatt, a Gyöngyös környéki Mátraszentimre, Parádsasvár, Gyöngyössolymos, Visonta és Markaz idegenforgalmi és társadalmi mutatóinak kedvező helyzete miatt, az Eger környéki Felsőtárkány, Bélapátfalva, Noszvaj, Novaj és Andornaktálya leginkább gazdasági és/vagy ellátottságbeli mutatóinak kedvező helyzete miatt kerültek a legfejlettebb falvak közé.

$\mathrm{Az}$ aprófalvas vizsgálatnál említett legkevésbé fejlett északkeleti és délnyugati térségek falvainak csoportjához kapcsolódnak a teljes faluállomány vizsgálatánál Szabolcs-Szatmár-Bereg megye Kisvárdai, Vásárosnaményi és Fehérgyarmati kistérségének települései, Hajdú-Bihar és Békés megyék megyehatár, illetve országhatár menti települései, és az egyébiránt fejlett településeket is magába foglaló Heves megye Heves települése környéki falvak. 


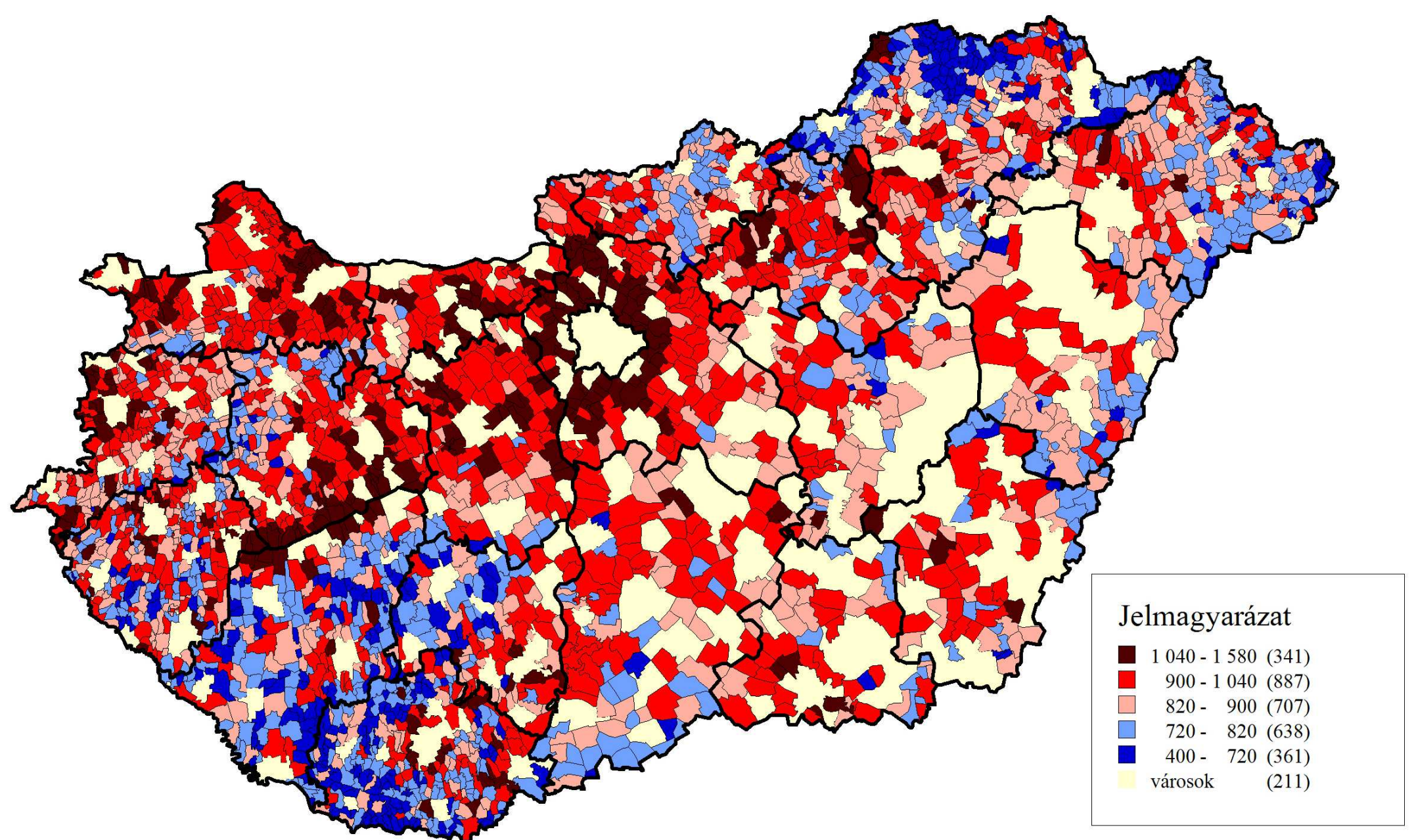

3. ábra. A falvak fejlettsége (Forrás: saját szerkesztés) 
A Körmend-Vasvár-Celldömölk-Pápa vonaltól délkeletre és a Beled-Kisbér vonaltól délre eső területeken összefüggő tömbben jelennek meg fejletlen falvak, melyek közül több vándorlási veszteséggel rendelkezik, az utóbbi években ellátottsága romlott, lakosaik valószínüleg a fejlettebb határmenti, vagy Balaton-parti térséget preferálták letelepedési helyként. A legfejletlenebb falvak Borsod-Abaúj-Zemplén, Somogy és Baranya megyékben zárt tömböt alkotnak (G. FEKETE É. 2001).

A teljes faluállományon belüli vizsgálat során a vizsgálatba vont falvak kedvező fejlettségi helyzetének fennállását illetve a fejlettségi helyzet negatív irányú elmozdulását, valamint a helyezéseket $(H)$ az alábbi tényezők eredményezik (3. táblázat):

- Azok a vizsgálatba vont falvak, amelyek több mutatócsoport mutatóinak fejlettségét tekintve is kimagasló értékekkel rendelkeznek, a teljes faluállományon belül is megőrizték jó összfejlettségi értéküket. Így pl. Szántód valamennyi mutatócsoporton belüli kimagasló fejlettsége eredményezte azt, hogy a teljes faluállomány statisztikai vizsgálata során felállított fejlettségi rangsornak is az élére került és ez a több mutatócsoporton belüli fejlettség eredményezi Gosztola, Fertőhomok és Dunaszentmiklós teljes faluállományon belüli kedvező adatokkal jellemezhető fejlettségét is. Dozmat (közlekedés, lakópark létrehozása), Csonkahegyhát (társadalom, intézményi ellátottság), Dörgicse (csatornázottság, épített örökség léte) és Hegymagas (infrastrukturális ellátottság) esetében a teljes faluállományon belüli jó fejlettségi pozíció megörzése érdekében elegendő volt egy-két mutatócsoporton belüli jó helyezés, mely a többi mutatócsoporton belüli kicsivel a mutatócsoport átlaga feletti eredményekkel társulva az összfejlettségen belüli is magas értékeket eredményezett.

- Villánykövesd (épített örökség), Tivadar (vendégéjszaka), Apátistvánfalva (társadalmi mutatók), Velemér (épített örökség, alacsony számú segélyezett) és Romonya (közlekedés, lakópark) esetében a teljes faluállományon belüli fejlettségi pozíció megtartásához nem voltak elegendők az egy-két mutatócsoporton belüli magas értékek. Villánykövesd ugyanis a társadalmi és közlekedési, Tivadar a társadalmi, közlekedési, ellátottsági, Apátistvánfalva a közlekedési, idegenforgalmi, Velemér a társadalmi és ellátottsági, Romonya szintén a társadalmi, ellátottsági mutatócsoportok értékeiben teljesítettek a teljes faluállomány mutatócsoportjainak átlagai alatt. 
- Azok a vizsgálatba vont települések, amelyek az aprófalvas statisztikai vizsgálat során a fejlettségi lista végére kerültek (Klárafalva, Alsómocsolád, Fony), a teljes faluállomány statisztikai vizsgálatában is a fejletlen települések között foglalnak helyet. Alsómocsolád és Fony valamennyi mutatócsoportjának értéke az egyes mutatócsoportok átlaga alatti, Alsómocsolád körjegyzőségi központ volta (1. kép 8. sz. melléklet), ipari funkciója, Fony körjegyzőségi központ volta, épített öröksége ellenére is. Bár Klárafalva közlekedési mutatócsoport értéke kifejezetten magas, ez az egy mutatócsoport önmagában nem kompenzálja a többi mutatócsoport értékeinek egyes mutatócsoport értékek átlagától való negatív irányú eltérését.

\begin{tabular}{|c|c|c|c|c|c|c|c|c|c|c|c|c|c|c|}
\hline Településnév & $\begin{array}{l}\text { Népes- } \\
\text { ség }\end{array}$ & H & $\begin{array}{l}\text { Társa- } \\
\text { dalom }\end{array}$ & H & \begin{tabular}{c|} 
Ellá- \\
tottság
\end{tabular} & $\mathbf{H}$ & $\begin{array}{c}\text { Gazda- } \\
\text { ság }\end{array}$ & $\mathbf{H}$ & $\begin{array}{l}\text { Közle- } \\
\text { kedés }\end{array}$ & H & $\begin{array}{c}\text { Idegen- } \\
\text { forgalom }\end{array}$ & $\mathbf{H}$ & $\begin{array}{c}\text { Összfej- } \\
\text { lettség }\end{array}$ & H \\
\hline Szántód & 317,13 & 45. & 143,18 & 45. & 356,35 & 6. & 270,62 & 62. & 205,62 & 350. & 277,73 & 6. & 1570,63 & 1 \\
\hline Dunaszentmiklós & 248,50 & 333. & 119,66 & 97. & 213,68 & 1049. & 255,11 & 245. & 203,87 & 383. & 116,07 & 111. & 1156,89 & 99 \\
\hline \begin{tabular}{|l|} 
Fertőhomok \\
\end{tabular} & 75,70 & 142. & 117,11 & 109. & 221,44 & 889. & 259,67 & 152. & 169,27 & 1680. & 39,69 & 777. & 1082,88 & 206 \\
\hline Hegymagas & 4,42 & 590. & 84,40 & 355. & 235,30 & 644. & 231,17 & 1012. & 186,70 & 892. & 94,09 & 164. & 1066,08 & 253 \\
\hline Gosztola & 284,04 & 112. & 153,38 & 29. & 55,47 & 2902. & 257,93 & 186. & 178,36 & 1263. & 127,60 & 89. & 1056,78 & 279 \\
\hline Dozmat & 306,81 & 60. & 69,82 & 646. & 202,12 & 1259. & 239,75 & 692. & 225,85 & 119. & 11,82 & 2463. & 1056,16 & 282 \\
\hline Dörgicse & 241,26 & 443. & 76,54 & 476. & 218,24 & 959. & 235,98 & 832 . & 170,26 & 1646. & 112,45 & 118. & 4,72 & 288 \\
\hline Csonk: & 243,77 & 397. & 86,13 & 333. & 218,60 & 956. & 253,25 & 281 . & 201,06 & 429. & 24,97 & 1589. & 1027,78 & 386 \\
\hline \begin{tabular}{|l} 
Villánykövesd \\
\end{tabular} & 188,83 & 2509 . & 60,93 & 962. & 201,30 & 1276. & 244,61 & 542 . & 180,88 & 1139. & 136,78 & 80. & 1013,33 & 451 \\
\hline Tivadar & 191,91 & 2402 . & 59,53 & 1021. & 155,43 & 2126. & 193,41 & 2097. & 142,82 & 2521 . & 240,00 & 19. & 983,10 & 616 \\
\hline Apát & 208,67 & 1594. & 156,02 & 23. & 157,44 & 2092. & 237,56 & 771. & 167,90 & 1748. & 30,18 & 1220. & 957,78 & 766 \\
\hline Velemér & 173,64 & 2782 . & 84,50 & 354. & 121,74 & 2545. & 255,46 & 228. & 154,68 & 2221 . & 160,80 & 51. & 950,84 & 807 \\
\hline Romonya & 262,06 & 208. & 65,20 & 784. & 131,07 & 2446. & 237,76 & 760. & 212,97 & 226. & 14,61 & 2322. & 923,67 & 1024 \\
\hline Klárafalva & 228,67 & 739. & 35,33 & 2430 . & 183,07 & 1655. & 204,30 & 1846. & 200,64 & 438. & 9,21 & 2634. & 861,23 & 1571 \\
\hline \begin{tabular}{|l|} 
Alsómocsolád \\
\end{tabular} & 215,19 & 1280. & 50,11 & 1553. & 162,44 & 2005. & 206,63 & 1783. & 133,62 & 2677. & 77,36 & 217. & 845,34 & 1727 \\
\hline Fony & 207,64 & 1662. & 82,83 & 378. & 110,69 & 2651. & 165,33 & 2545 . & 148,10 & 2401. & 22,81 & 1716. & 737,41 & 2503 \\
\hline
\end{tabular}

3. táblázat. A vizsgálatba vont települések mutatócsoportonkénti és összfejlettsége a teljes faluállományban

(Forrás: saját számítás alapján saját szerkesztés)

Az aprófalvak statisztikai vizsgálatánál megfogalmazott sikertényezőket a teljes faluállományon elvégzett statisztikai vizsgálat alapján, a fenti mutatócsoportonkénti vizsgálatot követően a következőképpen módosítom:

1. A teljes faluállományra elvégzett statisztikai vizsgálat is megerősítette Szántód esetében a Balaton közelséget, mint sikerességi tényezőt. Fenntartom azt a megállapításomat is, hogy a kis településméret kevés számú népességmozgása is nagymértékben javíthatja a település összfejlettségen belüli helyzetét. Továbbra is hangsúlyosnak találom a nemzetiségek jelenlétét a faluban. A települést jellemző magas vendégéjszaka számot és valamely turisztikai attrakció együttes jenlétét is a sikeresség tényezőjének tekintem, csakúgy, mint a település szuburbán voltát (lakásállomány növeléssel, lakópark létesítéssel). 
2. Fenntartom továbbá, hogy a határ menti helyzet, az épített örökség jelenléte a településen, a falu központi szerepkör jellege, illetve a jó közlekedés-földrajzi helyzet fejlesztő hatású egy falu életében. Hangsúlyozom azonban, hogy míg az aprófalvak csoportját tekintve elegendő lehet egy-két mutatócsoporton belül elért relatíve magas érték az összfejlettségen belüli magas pontértékekhez - ezt korábbi vizsgálat is igazolta (JózSA K. 2008) -, addig nagyobb sokaság esetében, vagyis a teljes faluállományon belüli magas fejlettségi pontok eléréséhez már egy-két mutatócsoporton belüli magas eredmény nem elegendő, ezeknek a mutatócsoportonkénti magas értékeknek társulni kell az egyes mutatócsoportok átlagértékeit meghaladó mutatócsoportonkénti értékekkel is.

3. Fenntartom továbbá a civil szervezetek magas arányát, a település lakosainak magas fokú iskolázottságát, a faluban élő alacsony számú segélyezettet és alacsony számú álláskeresőt, valamint a kistérségi és megyeközpont jó közúti és időtávolsági elérhetősége mellett a felsőrendü úthoz való közelséget is, mint sikerességi tényezőt. Az alapfokú intézményi ellátottság meglétét, a csatornázottság, vezetékes gázzal való ellátottság és internet elérés magas értékeit, mint más statisztikai vizsgálatokban kisebb hangsúlyt kapott tényezőket szintén a fejlődést segítő faktoroknak tekintem.

A megnevezett tényezők az összfejlettségi értékekkel korreláltatva pozitív korrelációt adnak. Az értékek alapján a legtöbb esetben közepes (0,309 és 0,670 közötti) korreláció áll fenn. A legmagasabb korrelációs értékeket a fiatalok aránya és az infrastrukturális ellátottsági mutatók valamint az összfejlettségi adatok közti sztochasztikus kapcsolat adja. Két olyan mutató van, amelynek értékei nem állnak összefüggésben a fejlettséggel, a közüzemi ivóvízhálózatba bekapcsolt lakások aránya, valamint a születési ráta értéke. Ennek egyrészt azt mutatja, hogy a falvak ivóvíz ellátottsága között ma már nincs érdemi különbség. Másrészt alátámasztja azt a korábbi megállapítást, mely szerint a népességszám növekedése nem jelent automatikusan fejlődő települést.

Mivel a fent említett korrelációs vizsgálatban a nemzetiségi mutató adta az egyik legalacsonyabb közepes korrelációs értéket, így ennek a mutatónak további vizsgálatát is elvégeztem (4. táblázat). Annak eldöntése érdekében, hogy a nemzetiségi jelenlét mennyiben járul hozzá egy település fejlettségéhez, az aprófalvak és a teljes faluállomány összfejlettségét újraszámoltam, a nemzetiségi mutató értéke nélkül. A falvakat (köztük az aprófalvakat is) 4 csoportba osztottam, a szerint, mennyi a településen a nemzetiségi lakosság aránya. Az egyes csoportok nemzetiségi mutató 
nélküli fejlettségi átlagértékei vonatkozásában az alábbi megállapítások tehetők. Azok a falvak (köztük aprófalvak), amelyekben a nemzetiségi arány $10 \%$ alatti, a legalacsonyabb összfejlettségi értékkel rendelkeznek. A fejlettségi értékek a nemzetiségi arány növekedésével együtt nőnek, kivéve a legmagasabb nemzetiségi aránnyal rendelkező településeken. A nemzetiségi jelenlét és a falu fejlettsége között tehát van összefüggés. Ez az összefüggés az aprófalvakban és a nyugat-magyarországi településeken még egyértelmübben mérhető.

\begin{tabular}{|c|r|r|}
\cline { 2 - 3 } \multicolumn{1}{c|}{} & $\begin{array}{c}\text { Falvak fejlettségének } \\
\text { átlaga, nemzetiségi mutató } \\
\text { nélkül }\end{array}$ & $\begin{array}{c}\text { Aprófalvak fejlettségének } \\
\text { átlaga, nemzetiségi mutató } \\
\text { nélküll }\end{array}$ \\
\hline $\begin{array}{c}\text { Nemzetiségi arány: } \\
0-10 \%\end{array}$ & 871,84 & 792,65 \\
\hline $\begin{array}{c}\text { Nemzetiségi arány: } \\
10-30 \%\end{array}$ & 910,72 & 828,15 \\
\hline $\begin{array}{c}\text { Nemzetiségi arány: } \\
30-50 \%\end{array}$ & 942,19 & 896,40 \\
\hline $\begin{array}{c}\text { Nemzetiségi arány: } \\
50-100 \%\end{array}$ & 886,61 & 836,53 \\
\hline
\end{tabular}

4. táblázat. A falvak és aprófalvak nemzetiségi mutató nélküli fejlettségi értékei, nemzetiségi arány függvényében

(Forrás: saját számítás alapján saját szerkesztés)

Úgy vélem, a teljes faluállomány statisztikai vizsgálata, az aprófalvas vizsgálattal megegyezően, szintén alátámasztja időben állandó sikerességi tényezők meglétének fontosságát, valamint a tényezőket jellemző komplexivitás szükségességét a település fejlődéséhez.

\subsection{A 2011-es népszámlálási adatok módosító hatása a falvak fejlettségi értékeire}

Mivel a 2011-es népszámlálás eredményei a dolgozat benyújtását megelőzően néhány hónappal elérhetővé váltak, fontosnak tartottam annak vizsgálatát, hogy adatbázisom legrégebbi (2001-es népszámlálási) adatai az aktuális 2011-es adatok fényében milyen mértékben módosulnak, és ez a módosulás milyen hatással van a mutatócsoportjuk és az összfejlettség értékeire. Mivel a 2001-es népszámlálás adatai a társadalom mutatócsoportban kerültek felhasználásra, így a továbbiakban ennek a mutatócsoportnak a legújabb népszámlálási értékekkel módosított elemzését ismertetem. 
A 2011-es népszámlálási adatok társadalom mutatócsoporton belüli változásai alapján elmondható, hogy a sikerességi tényezők közül a nemzetiségek jelenléte faktor még inkább megerősödött azokban az aprófalvakban, amelyekben döntően ennek a tényezőnek volt szerepe a település összfejlettsége tekintetében. Azokban az aprófalvakban, ahol más egyéb sikerességi tényezők is jelen vannak, a nemzetiségi tényező nem kapott akkora hangsúlyt a 2011-es népszámlálás értékeiben, mint a 2001es adatokban. A továbbiakban előbbi megállapításomat részletesebben is alátámasztom. A 2011-es népszámlálási adatokat felhasználva a társadalom 2 mutatócsoport mutatói tehát a következők:

\section{Társadalom 2}

— 1000 före jutó (müködő) civil szervezetek aránya, 2010

— 1000 före jutó anyaországgal rendelkező nemzetiségi lakosság aránya, 2011

- 18-X éves legalább középiskolai érettségivel rendelkezők aránya a megfelelő korúak százalékában, 2011

— 25-X éves egyetemi, föiskolai oklevéllel rendelkezők aránya a megfelelő korúak százalékában, 2011

A lakosság nemzetiségi adatainak 2011-es értékeit a korábbi 2001-es adatokkal összevetve a legnagyobb nemzetiségi lakossággal rendelkező településeken a nemzetiségi lakosság arányának kisebb mértékű csökkenése figyelhető meg (pl. Felsőszentmárton: 82,56\%-ról 75,39\%-ra). Ennek oka valószínüleg az, hogy a fiatal lakosság már inkább a többségi nemzethez tartozónak vallja magát, sok esetben már nem beszéli a nemzetiségi nyelvet, vagy nem tartja a szokásokat. Elmondható továbbá, hogy a nemzetiségi településeken már 2001-ben is jellemző magasabb érettségizett és diplomás arány (a megfelelő korúak százalékában) a 2001-es időszakról a 2011-es évre tovább növekedett (pl. Nardán a diplomával rendelkezők aránya 2001-ben 6,1\%, 2011ben 11,4\%). Ugyanakkor az érettségizettek és diplomások aránya a nem nemzetiségi településeken is nőtt (pl. Szamoskéren az érettségizettek aránya 2001-ben 2,1\%, 2011ben $3,5 \%$ ), a növekedés üteme azonban itt kisebb.

A vizsgálatba vont falvak összfejlettségi pontszámainak módosulása következtében fontosnak tartom elmondani, hogy valamennyi nemzetiségi vizsgálatba vont falu társadalom 2 mutatócsoportjának értéke növekedett 2001-ről 2011-re. A növekedés mértéke azonban eltérő volt a vizsgálatba vont falvakat illetően. Fertőhomok és Apátistvánfalva (2. kép - 8. sz. melléklet) társadalom 2 mutatócsoportjának fejlettségi értéke kis mértékben növekedett (Fertőhomokon 117,11-ről 119,03-ra, Apátistvánfalván 156,02-röl 158,31-re). Ez a kismértékü növekedés azonban az 
aprófalvak és a teljes faluállomány statisztikáját tekintve az összfejlettség alapján felállítható helyezésekben visszaesést eredményezett. A visszaesés oka a többi nemzetiségi és nem nemzetiségi település lakosságának a megfelelő korúak százalékában megnövekedett iskolai végzettség aránya.

A vizsgálatba vont falvak másik csoportjában (Villánykövesd, Hegymagas és Dunaszentmiklós) a társadalom 2 mutatócsoport értékei a társadalom mutatócsoporthoz képest jelentősen emelkedtek. Villánykövesden ez az érték 60,93-ról 98,62-re, Hegymagason 84,4-röl 116,24-re, Dunaszentmiklóson 119,66-ról 158,41-re növekedett. Ez a növekedés az aprófalvak összfejlettsége alapján felállítható települési helyezéseket tekintve legalább pozíció megtartáshoz, vagy kismértékü helyezésben való elörelépéshez volt elegendő. A teljes faluállomány statisztikai vizsgálatát tekintve ez a társadalom 2 mutatócsoporton belül való értéknövekedés már erőteljesebb pozíciónövekedést eredményezett (5. táblázat). Vagyis a társadalom 2 mutatócsoport értékeinek növekedése az aprófalvak közötti magasabb összpontszám elérését ereményezte, mely az aprófalvakban jelenlévő nemzetiség, és az ehhez kapcsolódó magasabb iskolai végzettség sikerességi tényező voltát erősíti.

\begin{tabular}{|c|c|c|c|c|c|c|c|c|}
\hline & \multicolumn{4}{|c|}{ Helyezés az aprófalvak statisztikáján belül } & \multicolumn{4}{|c|}{$\begin{array}{c}\begin{array}{c}\text { Helyezés a teljes faluállomány statisztikáján } \\
\text { belül }\end{array} \\
\end{array}$} \\
\hline & $\begin{array}{l}\text { Társadalom } \\
2001\end{array}$ & $\begin{array}{c}\text { Társadalom } \\
2011\end{array}$ & \begin{tabular}{|c|c|} 
Összfej- \\
lettség 2001
\end{tabular} & $\begin{array}{c}\text { Összfej- } \\
\text { lettség } \\
2011\end{array}$ & $\begin{array}{c}\text { Társadalom } \\
2001\end{array}$ & $\begin{array}{c}\text { Társadalom } \\
2011\end{array}$ & $\begin{array}{c}\text { Összfej- } \\
\text { lettség } \\
2001\end{array}$ & $\begin{array}{c}\text { Összfej- } \\
\text { lettség } \\
2011\end{array}$ \\
\hline Szántód & 16 & 54 & 1 & 1 & 45 & 140 & 1 & 3 \\
\hline Dunaszentmiklós & 30 & 21 & 15 & 16 & 97 & 36 & 99 & 85 \\
\hline Fertőhomok & 33 & 64 & 29 & 42 & 109 & 177 & 206 & 241 \\
\hline Hegymagas & 107 & 70 & 38 & 38 & 355 & 197 & 253 & 213 \\
\hline \begin{tabular}{|l|} 
Gosztola \\
\end{tabular} & 12 & 22 & 42 & 55 & 29 & 37 & 279 & 315 \\
\hline Dozmat & 183 & 82 & 43 & 37 & 646 & 232 & 282 & 212 \\
\hline Dörgicse & 134 & 101 & 45 & 44 & 476 & 288 & 288 & 244 \\
\hline Csonkahegyhát & 96 & 126 & 65 & 76 & 333 & 350 & 386 & 401 \\
\hline Villánykövesd & 265 & 133 & 75 & 65 & 962 & 367 & 451 & 356 \\
\hline Tivadar & 278 & 243 & 99 & 100 & 1021 & 744 & 616 & 580 \\
\hline \begin{tabular}{|l} 
Apátistvánfalva \\
\end{tabular} & 9 & 23 & 122 & 141 & 23 & 38 & 766 & 826 \\
\hline Velemér & 106 & 66 & 134 & 112 & 354 & 180 & 807 & 664 \\
\hline Romonya & 226 & 139 & 173 & 150 & 784 & 379 & 1024 & 848 \\
\hline \begin{tabular}{|l|} 
Klárafalva \\
\end{tabular} & 717 & 618 & 314 & 312 & 2430 & 2052 & 1571 & 1523 \\
\hline \begin{tabular}{|l|} 
Alsómocsolád \\
\end{tabular} & 403 & 269 & 360 & 326 & 1553 & 821 & 1727 & 1566 \\
\hline Fony & 111 & 168 & 725 & 721 & 378 & 463 & 2503 & 2487 \\
\hline
\end{tabular}

5. táblázat. A vizsgálatba vont falvak helyezésének változása az aprófalvak és a teljes faluállomány társadalom mutatócsoport és összfejlettségi értékei között a 2011-es népszámlálási adatok hatására

(Forrás: saját számítás alapján saját szerkesztés)

A 2011-es népszámlálási adatok által módosított társadalom 2 mutatócsoport értékeivel számolt összfejlettségi adatokat tekintve az aprófalvas településállomány egészét vizsgálva azonban érdemi változások nem történtek. Mindössze az Őriszentpéteri, Pécsi és Siklósi kistérségek aprófalvainak az összfejlettségi értékei 
növekedtek. Azonban a Balaton vonalától keletre egy-egy aprófalu magas összfejlettségi értékének alapját továbbra is valamilyen turisztikai potenciál, vagy jó közlekedésföldrajzi helyzet jelenti.

Ha a teljes faluállományt tekintve a 2011-es népszámlálási adatok társadalom 2 mutatócsoportjának értékeiből számolt összfejlettséget vizsgálom (4. ábra), a nyugati országrész szlovákiai és osztrák határmenti városainak környékén, vagyis a Győr, Mosonmagyaróvár, Sopron, Kőszeg és Szombathely körüli falvak között találhatók magasabb fejlettségi értékek. Ez a 2001-es értékekhez mért eltérés azonban nem csak a nemzetiségi területek amúgy is magasabb iskolai végzettségéhez köthető, hanem az ország különböző területein végzett diplomás réteg nyugat felé történő migrációjához is. Mivel a nyugati határmente aprófalvainak összfejlettségi értéke alig változott a társadalom 2 mutatócsoport értékeinek a hatására, az is valószínüsíthető, hogy a diplomások nyugati migrációjánál a városkörnyéki falvak mérete is döntő fontosságú lehetett, vagyis nem a legkisebb népességszámú falvakat választották letelepedési helyként.

A nyugati határmente falvainak fejlettségi értékeiben bekövetkezett növekedés a Balaton - Budapest vonalon a Balatonfüredet környezö falvakban, a SzékesfehérvárMór közötti településeken és a Budapesti Agglomeráció néhány nyugati falvában megfigyelhető.

A térképröl jól látható az is, hogy az egyetemvárosok körüli falvakban növekedtek a fejlettségi értékek. A végzett diplomás rétegnek azonban egy része marad csak a nagyvárosok környéki településeken, más részük újabban a városban marad.

A 2011-es népszámlálás adataival módosított társadalom mutatócsoport értékeinek változása tehát növelte egyrészt a nemzetiségek, mint sikerességi faktor szerepét a település fejlődése szempontjából, másrészt növelte az iskolai végzettség szerepét a település sikerességét tekintve. Igazolta továbbá, hogy a két tényező szoros kapcsolatban van egymással, valamint, hogy a települési fejlettségi helyezéseket tekintve kismértékü társadalmi mutatócsoporton belül történő egységnormált értéknövekedés nem elegendő összfejlettségi pozíciójavításhoz (pozícióvesztést is eredményezhet). A 2011-es népszámlálás iskolázottsági adatai rámutattak arra is, hogy a kvalifikált munkaerő döntően a nyugati országrészbe és a főváros környékére áramlik.

A 2011-es népszámlálás megerősítette továbbá azt a dilemmát, mely szerint a népességszám növekedése nem lehet a sikeresség elégséges kritériuma. A vizsgálatba vont falvak közül Fertőhomok és Szántód - a statisztikailag legfejlettebbb falvak közé 
került két település - 2010-re „kiesett” az aprófalvak kategóriájából. Mindkét falu esetében több mutató együttes jelenléte eredményezett magas fejlettségi összpontszámot a statisztikai vizsgálatokban, valószínüsíthetően ezeknek köszönhetően növekedett a falvak népessége 500 fő fölé. A többféle magas fejlettségi értéket adó mutató állandóságának köszönhetően a két település 2011-re tovább növelte népességszámát.

A 2010-ig népességét növelő Klárafalva egy másik csoportba tartozik. A falu csak egy mutatócsoportban, a közlekedés mutatócsoportban ért el magas pontszámot a statisztikai vizsgálat során, népessége a továbbszámított adatok szerint 2010-ig növekedett ${ }^{19}$.

Mivel a fejezetben lehatárolt statisztikai sikerességi tényezőket, azaz a „kívülről” megadhatő fejlődést eredményező faktorokat nem tartom koplex szemléletű tényezőcsoportnak, a továbbiakban a sikerességi indikátorokat „belülről” kutatva vizsgálom, és hipotéziseim szerint bővítem azok csoportját.

\footnotetext{
${ }^{19}$ A 2011-es népszámlálás adatai szerint Klárafalva népessége 500 fő alatti. Tehát csak a továbbszámított adatok alapján „,nőtt ki” az aprófalvak kategóriájából. A Klárafalva típusú, több éven át népességnövelö, és csupán egy-egy mutató tekintetében magas fejlettséggel rendelkező falvak sikeres települések közé kerülése tehát erősen vitatható.
} 

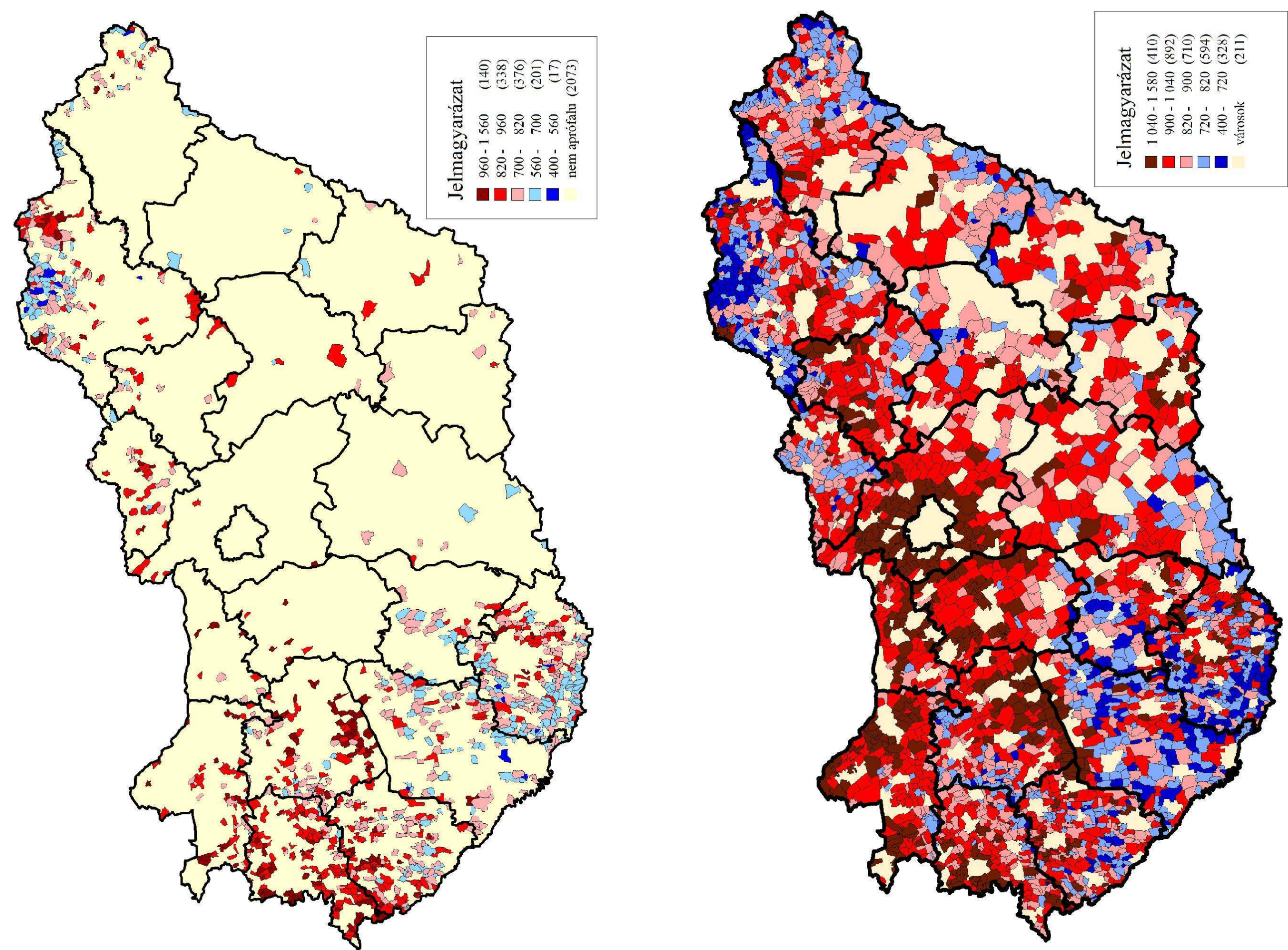

4. ábra. Az aprófalvak és a teljes faluállomány fejlettségének alakulása a 2011-es népszámlálási adatok módosító hatására (Forrás: saját szerkesztés) 


\subsection{A vizsgálatba vont falvak utcaképe, épületállománya}

A vidéki térségek épületállományának állagmegóvása, fejlesztése több éve a vidékfejlesztés sajátja, ami nem csak renoválást, virágosítást jelent, hanem a találkozási helyszínek, intézmények (iskola, óvoda, teleház, templom) pénzügyi forrásokat felhasználó megújítását is (OROSZ B. 1999). A vidékfejlesztés e lépései még a hátrányos helyzetü területeken is megfigyelhetök. Ezért is tartottam fontosnak annak vizsgálatát, hogy vajon a fejlett aprófalvakat milyen épületállomány jellemzi. Az épületállomány felmérés szintén egy „kívüllőll” mérő módszer, így jól illeszkedik e témakörbe, a statisztikai elemzések közé. Ugyanakkor az, hogy a vizsgált falvak épületei milyen állapotban vannak, milyen a lakásépítés dinamikája, már a helyi társadalom, a településvezetés hozzáállásától is függ. A társadalmi szerepvállalás kérdésköre pedig megteremti az összekötő, átvezető kapcsot a következő fejezet „belülről” mért sikerességi tényezői irányába.

Az épületállomány állapotát a terepi munka folyamán valamennyi vizsgálatba vont aprófaluban felmértem a szerint, hogy az épület jó (ide soroltam az új épületeket is), rossz, átlagos állapotú-e, valamint külön felmértem az üdülőket (6. táblázat). A vizsgált falvakban felmért épületek száma nem egyezik meg a KSH statisztikában szereplő lakásállomány darabszámmal, mivel a kereskedelmi egységek, intézmények állapotát is jelöltem a kutatás során.

\begin{tabular}{|c|c|c|c|c|c|c|c|}
\hline \multirow[b]{2}{*}{ Település } & \multicolumn{5}{|c|}{ Épületek száma } & \multicolumn{2}{|c|}{$\begin{array}{c}\text { Épületek üdülő́k nélküli } \\
\text { aránya }\end{array}$} \\
\hline & Jó/új & Rossz & Átlagos & Üdülő & Össz felmért & \begin{tabular}{|l|} 
Jó/új aránya \\
\end{tabular} & Rossz aránya \\
\hline 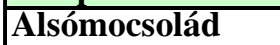 & 18 & 20 & 112 & 0 & 150 & 12,0 & 13,3 \\
\hline \begin{tabular}{|l} 
Apátistvánfalva \\
\end{tabular} & $\overline{41}$ & $\overline{14}$ & $\overline{110}$ & 5 & 170 & 24,8 & 8,5 \\
\hline \begin{tabular}{|c|} 
Csonkahegyhát \\
\end{tabular} & 24 & 35 & 86 & 0 & 145 & 16,6 & 24,1 \\
\hline Dozmat & 19 & 13 & 61 & $\overline{0}$ & 93 & 20,4 & 14,0 \\
\hline Dörgicse & 45 & 23 & 58 & $\overline{38}$ & 164 & 35,7 & 18,3 \\
\hline Dunaszentmiklós & 89 & 22 & 104 & $\overline{42}$ & 257 & 41,4 & 10,2 \\
\hline Fertóhomok & 91 & 7 & 130 & 260 & 488 & 39,9 & 3,1 \\
\hline Fony & 26 & 56 & 119 & 28 & 229 & 12,9 & 27,9 \\
\hline \begin{tabular}{|l|} 
Gosztola \\
\end{tabular} & 29 & $\overline{3}$ & 14 & $\overline{0}$ & 46 & 63,0 & 6,5 \\
\hline Hegymagas & 38 & 25 & 68 & 34 & 165 & 29,0 & 19,1 \\
\hline Klárafalva & 22 & 48 & 133 & 0 & 203 & 10,8 & 23,6 \\
\hline \begin{tabular}{|l|} 
Romonya \\
\end{tabular} & 48 & 27 & 97 & 0 & 172 & 27,9 & 15,7 \\
\hline Szántód & 77 & 11 & 177 & 488 & 753 & 29,1 & 4,2 \\
\hline Tivadar & 18 & 12 & 58 & 126 & 214 & 20,5 & 13,6 \\
\hline Velemér & 6 & 4 & 65 & 4 & 79 & 8,0 & 5,3 \\
\hline Villánykövesd & 15 & 18 & 103 & 0 & 136 & 11,0 & 13,2 \\
\hline
\end{tabular}

6. táblázat. A vizsgálatba vont falvak épületállományának megoszlása a jó/új, rossz, átlagos állapot és üdülőfunkció szerint (Forrás: saját számítás alapján saját szerkesztés) 
A felvett adatok alapján elmondható, hogy a statisztikai adatelemzés eredményei alapján sikeres aprófalvak épületállománya több jó állapotú illetve új építésủ lakásból, épületből áll. Az épületállomány üdülők nélküli összességéből a jó állapotú és új építésü lakások, épületek aránya az egyik leggazdagabb Gosztolán a legmagasabb (63\%), de a magas összefejlettséggel, lakossági és településvezetési aktivitással jellemezhető Fertőhomokon, Hegymagason, Szántódon és Dörgicsén is magas. Ezeken a településeken nem csak a lakóépületek, hanem az intézmények, kereskedelmi egységek állagmegóvására is figyelnek. Mindez azért is fontos, mert a társadalom struktúrája, intézményei, kultúrája visszahat az egyén életkörülményeire, viselkedésére, gondolkodására (ANDORKA R. 1995). Vagyis valószínűsíthetően azokban az aprófalvakban, amelyekben a közintézmények épületállományának állagmegóvására gondot fordítanak, a lakosság is figyelmet fordít életkörülményeinek javítására.

A fejlett és egyben magas üdülőszámmal rendelkező Szántódon és Fertőhomokon az üdülöket is karbantartják, rossz állapotú, elhanyagolt üdülö alig van, csakúgy, mint az idegenforgalmi mutatócsoportban kimagasló értékekkel rendelkező Tivadar üdülői között. Az elmúlt években a faluépítés és -fejlesztés terén a városkörnyéki falvakba letelepülő családok építkezéseinek és a második otthont vagy üdülőt építők aktivitásának szerepét többen publikálták (KÓRÓDI J. 2004), mondván az üdülőövezetek falvainak új arculata lényegében az utóbbi két-három évtizedben alakult ki.

A statisztikai vizsgálatokban fejletlenebb települések közé került Fony, vagy Alsómocsolád utcáin már jóval magasabb az átlagos, vagy rossz állapotú épületek aránya. Az összfejlettségi értékeket tekintve a középmezőnyben található Csonkahegyhát körjegyzőségi szerepköre ellenére is az egyik legmagasabb rossz állapotú épületettel rendelkező aprófalu $(24,1 \%)$.

Mivel a kutatott aprófalvak közül a statisztikai vizsgálat alapján sikeresnek nevezhető falvak a lakásépítéseket tekintve is magas értékeket mutattak, így statisztikai adatok elemzésével felmértem az újonnan épített lakások arányát a teljes faluállományban is. Arra kerestem a választ, vajon a kimagasló lakásépítésekkel rendelkező vizsgálatba vont aprófalvak mellett milyen más falvak jellemezhetők hasonlóan magas adatokkal, és ezek a települések milyen területi elhelyezkedést mutatnak (5. ábra).

A lakásépítés dinamikájának vizsgálata során arra az eredményre jutottam, hogy az aprófalvak és az 500 főnél népesebb települések közül egyaránt megtalálhatók falvak a legtöbb és legkevesebb lakásépítést felmutató falvak között a 2001-2010 között egy 
före számított, évente ezrelékben kifejezett lakásépítési adatok alapján. Az újonnan épített lakások több éves terminusát figyelembe véve a faluállományon belüli településméret tehát a várttól eltérően nem volt döntő fontosságú.

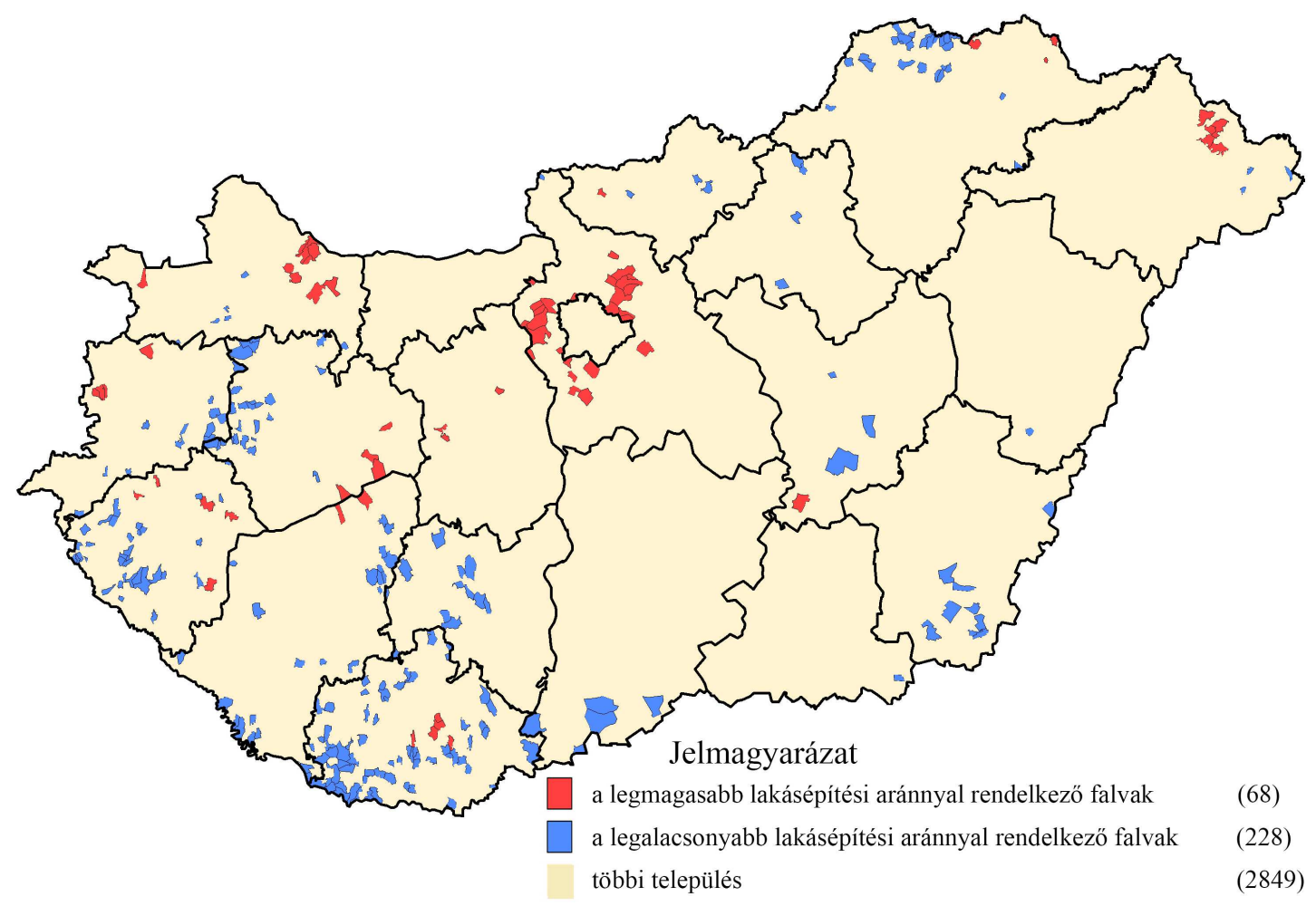

5. ábra. A legmagasabb és legalacsonyabb lakásépítési aránnyal rendelkező falvak (Forrás: saját szerkesztés)

A magas lakásépítési aránnyal rendelkező falvak területi elhelyezkedését tekintve elmondható, hogy azok döntően Budapest, a nagyvárosok és a Balaton környékére tehetők, magas értékeik szuburbanizációs folyamatokkal magyarázhatók. Szembetűnő viszont, hogy a legmagasabb lakásépítési aránnyal rendelkező falvak közül csak Magyarország észak-keleti részén látunk koncentrációt, ami nem a nagyváros(ok) környékére költözésnek, hanem a térséget 2001-ben sújtott árvízi katasztrófának köszönhető.

Az alacsony lakásépítési aránnyal jellemezhető települések a Cserehát térségében, a korábban már elköltözés kapcsán említett észak-nyugati határmente és a Balaton közötti területen, a délnyugati határmentén, Baranya, Tolna megyékben és Békés megye délkeleti részén koncentrálódnak.

A terepbejárás alkalmával az épületek állagának számbavétele mellett felmértem azt is, hogy mely vizsgálatba vont településeken vannak jelen az adott térség 
hagyományos népi építészetének felújított házai és hol vannak tájidegen, vagy az aprófalvak településképétől jelentős mértékben eltérő lakóépületek, valamint kimondottan nagy értékü ingatlanok.

A népi építészet felújított parasztházai döntően három helyre koncentrálódnak. Egyrészt az északkeleti országrészbe (Fony, Tivadar), másrészt a Balaton környékére (Dörgicse, Hegymagas), harmadrészt a nemzetiségi falvakba (Apátistvánfalva, Fertőhomok, Dunaszentmiklós és Villánykövesd) (6. ábra). Ezek egy része a falusi szállásadásban hasznosul, más része a település történetét bemutató tájházként funkcionál. Ezeken a településeken a szakirodalomból ismert „nosztalgikus” és „megőrző-nosztalgikus közötti átmenetet” mutató értékmegőrzéssel találkozhatunk (TAMÁSKA M. 2011).

Két szuburbán településen, Dozmaton és Romonyán a terepi munka során lakópark építés folyt. Mindkét faluban törekedtek arra, hogy a tájba illő családi házakat alakítsanak ki (ezt az ingatlanfejlesztőkkel folytatott interjúk is megerösítették). A Dunaszentmiklóson található több mint 5 hektáros kiterjedésü üdülőfalu házai (70 apartman) is az aprófaluba illő stílusjegyekkel rendelkeznek. A Gerecse Tájvédelmi Körzet területén épült beruházás a szállásfunkción kívül számos szolgáltatást nyújt wellness, fitnesz, mini-market, gyermekfelügyelet - és fokozottan épít a konferenciaturizmusra. Arra, hogy az épületállomány a falvakban ily módon megújult és megszépült, az ingatlanpiac is pozitívan reagált, a régebbi építésű ingatlanok árai is emelkedtek e két településen.

Az ingatlanárak emelkedése a szuburbán településeken nem ismeretlen jelenség (Egedy T. - KovÁCs Z. - SzÉKELY G. - SzEMZŐ H. 2002). Nagy értékü ingatlanokat a keleti országrész kivételével szinte valamennyi vizsgálatba vont faluban felmértem. Ezek az ingatlanok döntően lakóépületek, a Balaton közeli falvakban nyaralók, Romonyán és Dozmaton lakóparkok épületei, Dunaszentmiklóson apartmanok, Gosztolán szálloda.

A statisztikai adatokból a lakásépítés dinamikája jól nyomon követhető, az azonban, hogy a régi építésú lakások állapota milyen, az épületállomány állagmegóvására fordít e gondot a településvezetés, vagy a lakosság, a terepi munka során volt felmérhető. Az épületállomány felmérés kapcsán összegezve elmondható, hogy a fejlett falvakban a lakóépületek és egyéb ingatlanok állagmegóvására is hangsúlyt fektet a helyi társadalom, a magas üdülőszámmal jellemezhető falvakban az üdülők karbantartására is gondot fordítanak. Az utóbbi évek legdinamikusabb 
lakásépítéseit tekintve az 500 fő alatti falvakban is szép számmal találhatók a többi falutól magasabb értékekkel jellemezhető települések, és nem csak az extrém kis lakosságszámú falvak egy före eső lakásépítési adatai következtében.

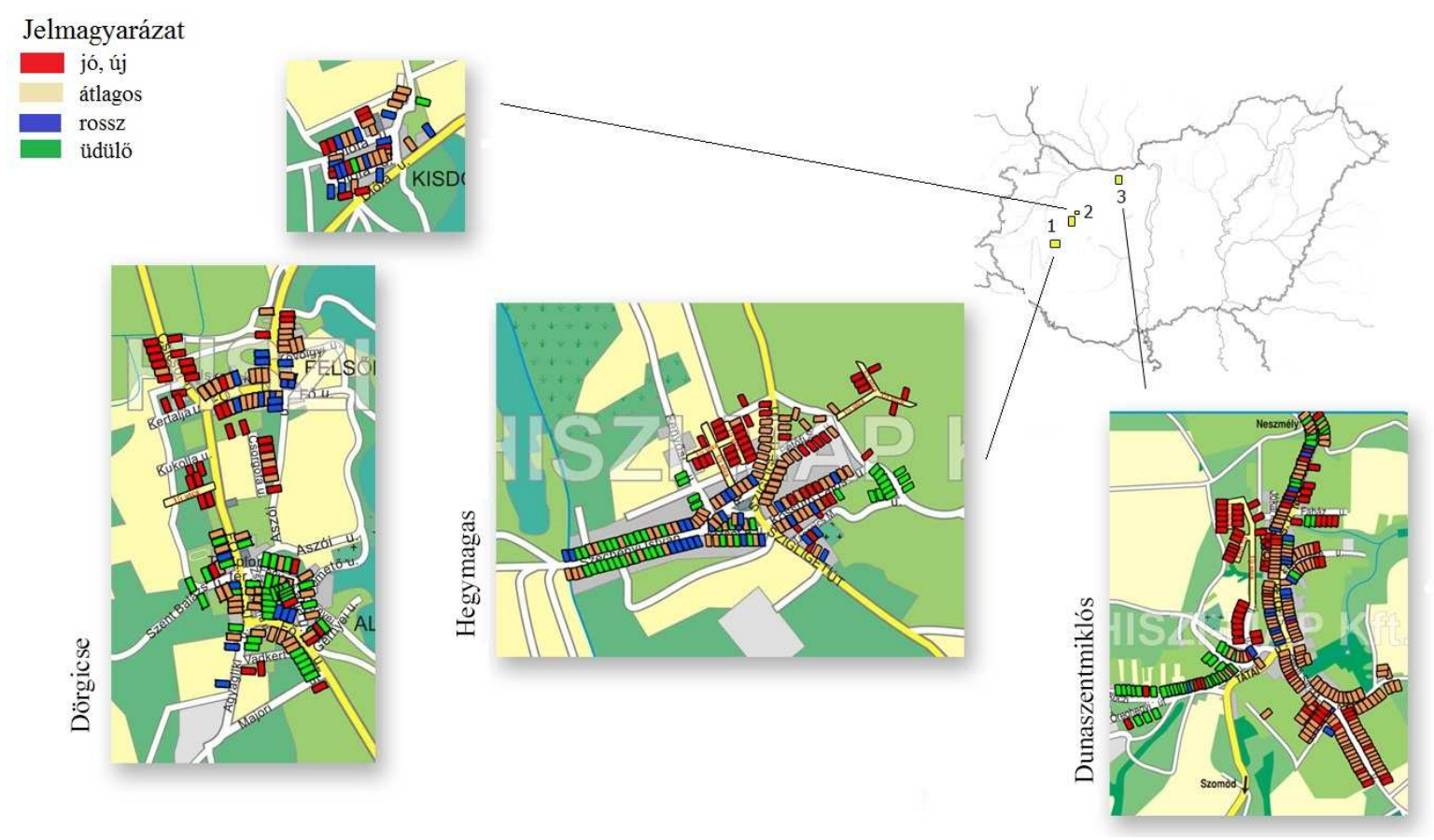

6. ábra. Dörgicse, Dunaszentmiklós és Hegymagas épületállományának állapota (Forrás: saját szerkesztés) 


\section{A SIKERESSÉG TÉNYEZŐI „BELÜLRŐL”, A LAKOSSÁG ÉS A HELYI ELIT VÉLEMÉNYÉNEK TÜKRÉBEN}

\subsection{Lakossági vélemények a vizsgálatba vont településekről, azok sikerességi tényezőiről}

Már az épületállomány felmérés kapcsán is említettem a társadalom szerepét a falvak életében. A továbbiakban a siker tényezőit a társadalom oldaláról, „belülről” vizsgálom. A lakossági kérdőívek (7. ábra) feldolgozását követően, azokat a korábbi statisztikai eredményekkel összevetve az alábbi megállapítások tehetők. Elmondható, hogy a vizsgálatba vont falvak lakosai általában szeretnek a falujukban élni, és nem költöznének el a településről. A helyben maradás okaként megjelölt tényezők három csoportra bonthatók.

Első a kötődés köré szerveződik: „,itt születtem”, „itt nőttem fel”, „itt él a családom”, itt van a munkahelyem” stb. A második csoportban a kis településméretből fakadó csendet, nyugalmat, a környezet minőségét jelölik meg a válaszadók kötődésük okaként. A környezet minősége azért is fontos tényező, mert ha a külső motívumok szerepe növekszik, az magával vonja a belső motívumok szerepének a növekedését is, és fordítva" (BANDUR, A. 1986). A harmadik válaszcsoport a természet közelségét és az abból eredő előnyöket hangsúlyozza.

A statisztikai vizsgálatban a fent megnevezett tényezők nem, vagy csak nehezen lettek volna mérhetők. Így a statisztikai adatelemzés során a településhez való kötődés, vagy a lakosok által megnevezett csend és nyugalom fontossága a kvantitatív elemzésben nem jelentkeztek sikerességi faktorként. A lakosok által említett természeti tényezők fontossága a település fejlődése szempontjából azonban párhuzamba állítható a statisztikai adatelemzés idegenforgalom mutatócsoportjának az összfejlettségbeli magasabb pontértékekhez szükséges elemeivel. Hiszen magasabb vendégéjszaka szám eléréséhez, vagy magasabb számú vendéglátóhely kialakításához a lakosok szerint is elengedhetetlen valamilyen idegenforgalmi adottság, vonzerő.

A válaszadók igen kis hányada gondolja úgy, hogy elköltözne a falujából. Az elköltözést kilátásba helyező települések (Fony, Klárafalva) már a statisztikai vizsgálatban is a fejlettségi listák végére kerültek, lakosaik jobb munkahelyi adottságokat, jobb életkörülményeket, magasabb fokú ellátottsági értékeket várnának el településüktől. 


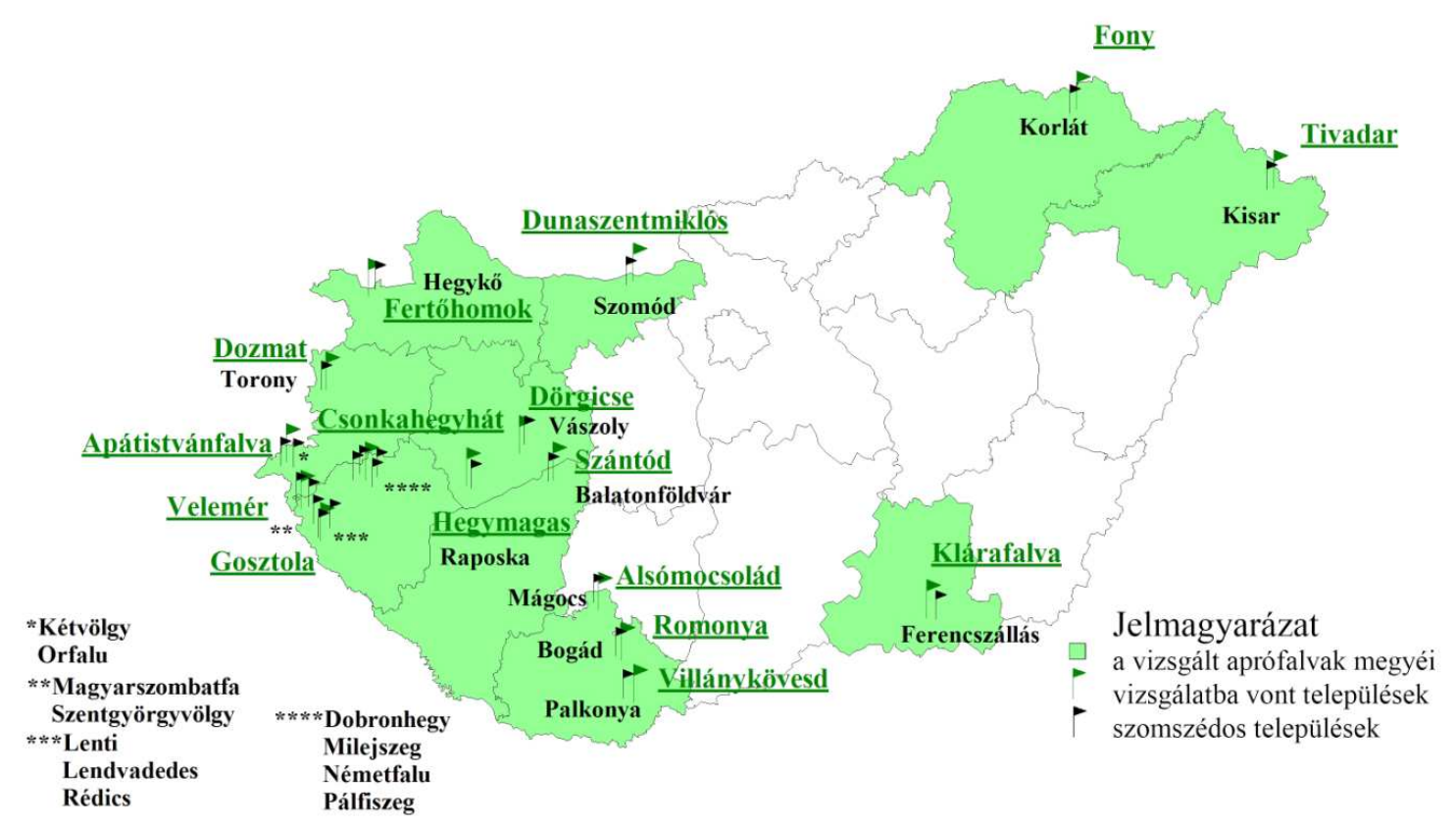

\begin{tabular}{|l|r|}
\hline Település & Kérdőívek száma \\
\hline Alsómocsolád & 18 \\
\hline Apátistvánfalva & 23 \\
\hline Csonkahegyhát & 18 \\
\hline Dozmat & 15 \\
\hline Dörgicse & 18 \\
\hline Dunaszentmiklós & 18 \\
\hline Fertőhomok & 22 \\
\hline Fony & 24 \\
\hline Gosztola & 2 \\
\hline Hegymagas & 16 \\
\hline Klárafalva & 20 \\
\hline Romonya & 24 \\
\hline Szántód & 17 \\
\hline Tivadar & 17 \\
\hline Velemér & 9 \\
\hline Villánykövesd & 15 \\
\hline
\end{tabular}

Rédics

\begin{tabular}{|l|r|}
\hline Település & Kérdőivek száma \\
\hline Balatonföldvár & 12 \\
\hline Bogád & 11 \\
\hline Dobronhegy & 7 \\
\hline Ferencszállás & 11 \\
\hline Hegykő & 12 \\
\hline Kétvölgy & 8 \\
\hline Kisar & 9 \\
\hline Korlát & 12 \\
\hline
\end{tabular}

\begin{tabular}{|l|r|}
\hline Település & Kérdőívek száma \\
\hline Lendvadedes & 6 \\
\hline Lenti & 9 \\
\hline Mágocs & 9 \\
\hline Magyarszombatfa & 6 \\
\hline Milejszeg & 18 \\
\hline Németfalu & 9 \\
\hline Orfalu & 5 \\
\hline Pálfiszeg & 8 \\
\hline
\end{tabular}

\begin{tabular}{|l|r|}
\hline Település & Kérdőivek száma \\
\hline Palkonya & 9 \\
\hline Raposka & 9 \\
\hline Rédics & 9 \\
\hline Szentgyörgyvölgy & 6 \\
\hline Szomód & 9 \\
\hline Torony & 9 \\
\hline Vászoly & 9 \\
\hline
\end{tabular}

\begin{tabular}{|l|}
\hline Vizs gálatba vont \\
települések kérdő- \\
íveinek száma: 276 \\
\hline Szomszédos \\
települések kérdő- \\
íveinek száma: 212 \\
\hline \\
Összesen: 488 \\
\hline
\end{tabular}

7. ábra. A vizsgálatba vont falvakban és a szomszédos településeken felvett értékelhető kérdőívek megoszlása (Forrás: saját szerkesztés 
A vizsgálatba vont falvak három legkedveltebb és legkevésbé kedvelt tényezőjéről is kérdeztem a helyben és a szomszédos településeken élő lakosokat. A kérdés alapvetően arra szolgált, hogy olyan további fejlődést segítő, vagy hátráltató elemek is feltárhatók legyenek, amelyek a statisztikai elemzés során rejtve maradnak. A leginkább kedvelt tényezők között is fontos volt a természeti és a közösségi értékek szerepe. A társadalmat célzó vizsgálatok nagyobb léptékben ezek fontosságát már igazolták (BERTA GY. 2005).

A legkevésbé kedvelt tényezők döntően közösségi problémák, mint „pletyka”, „,irigység”, „elégedetlenség a polgármester személyével, vagy a képviselőtestülettel”. Villánykövesden, ahol a polgármester személyével és a képviselőtestülettel szemben a legegyértelműbb volt a lakossági elégedetlenség, a kérdöívek felvétele és a dolgozat benyújtása közti időben lezajlott önkormányzati választásokon mind a polgármester, mind a képviselőtestület cseréje megtörtént. A kérdőíves felmérés tehát rámutatott olyan közösségi tényezők fontosságára egy falu sikeressége tekintetében, mint a lakosság közti jó viszony, vagy a településvezető személyével szembeni elégedettség.

A statisztikai fejlettségi rangsor középmezőnyében végzett falvakban (Apátistvánfalva, Velemér, Romonya) a lakosság a közösségi problémák mellett intézménybezárásokról, infrastrukturális hiányosságokról, közlekedési problémákról is beszámolt (8. ábra). Ezekben a falvakban a fent említett mutatók értékei külön-külön is elmaradtak a statisztikai vizsgálatokban az aprófalvak átlagától.

A kevésbé kedvelt dolgok felsorolásánál a válaszadók közül sokan (leginkább a statisztikai vizsgálatban legfejlettebb falvak közé került falvak - Szántód, Fertőhomok, Hegymagas, Dunaszentmiklós - nyilatkoztak úgy, hogy nincs olyan dolog, amit ne szeretnének a falujukban. Ezekben a falvakban a lakosok kötődése a településhez valamint a természeti értékek iránt érzett büszkeség már az előző kérdések során is a legerőteljesebb volt a vizsgálatba vont falvak között ${ }^{20}$.

\footnotetext{
20 Mivel doktori dolgozatomban törekszek arra is, hogy a felvett kérdőívek eredményei jól szemléltethetőek legyenek, így a lakossági kérdőívek eredményeihez kapcsolódva egy a statisztikai fejlettségi rangsorban a középmezőnyben végzett aprófalu (Apátistvánfalva) és szomszédos települési (Kétvölgy és Orfalu) példáján keresztül mutatom be a lakosság által megfogalmazott sikeresség tényezőit. Az ábrák központi részében minden esetben a vizsgálatba vont településeken feltett kérdések és azok válaszai, a központi részt övezően, a szomszédos településeken feltett, a vizsgálatba vont aprófalura vonatkozó kérdések és az azokra adott válaszok láthatók.
} 


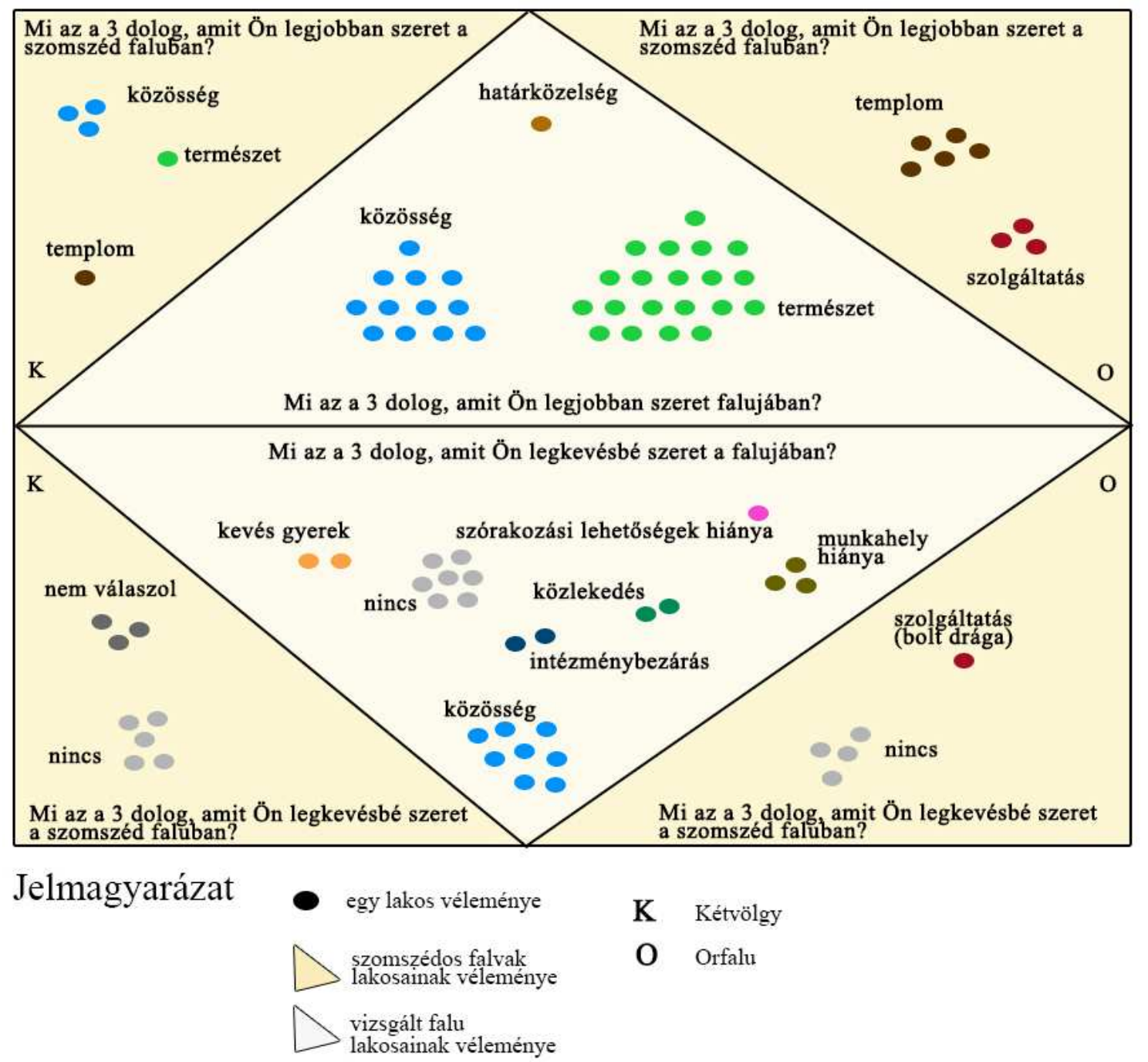

8. ábra. Apátistvánfalva és szomszédos településeinek lakossági véleménye a falu leginkább, és legkevésbé kedvelt tényezőit illetően

(Forrás: saját szerkesztés)

A turisztikai vonzerő vonatkozásában azokon a településeken kaptak nagyobb hangsúlyt az épített örökségek, illetve a természeti adottság, mint turisztikai potenciál, amelyek az üdülés szempontjából kifejezetten vonzó térségben helyezkednek el (Szántód, Tivadar), illetve azokban (mint kitörési lehetőség), amelyekben, és amelyek környékén nincs országos jelentőségű attrakció, pl. Fony. Abban a kérdésben, hogy mi az a három dolog, amit a települések lakosai megmutatnának egy ide látogató turistának a lakossági válaszok mind az épített örökséget, mind a természeti értékeket megjelölték. A szomszédos településeken felvett kérdöívekben, különösen ott, ahol a vizsgálatba vont aprófalu és a szomszédos település is gazdag természeti értékekben, a vizsgálatba vont falu épített öröksége hangsúlyosabb szerepet kapott. Vagyis a vizsgálatba vont falvak lakosai hajlamosak elfelejteni a településükön fellelhető vonzeröt, ha a környék 
vonzerőben bővelkedik, míg a szomszédos falvak lakosai számon tartják a vizsgált falvak vonzerőit is (Raposka, Palkonya).

A turisztikai értékek fontossága tehát ismételten igazolható. Ez a potenciál azonban a statisztikai adatelemzésből nem kimutatható problémákat is hordoz magában. Szántód esetében az üdülőjelleg konfliktusokat eredményez az „őslakosok” és a „nyaralók” között, mely konfliktus nem új keletű dolog, sem hazánkban, sem más országokban (DAHRENDORF, R. 1994). Tivadar lakosai a turizmus szezonalitását is hangsúlyozzák, és a téli hónapokban bekövetkező „pangás” problematikáját fogalmazzák meg. A turizmus adta lehetőségekkel egyidőben jelentkező konfliktusok kiküszöbölése azonban mindenképp szükséges lenne. Márcsak azért is, mert néhány lakos elégedetlensége könnyen válhat a településvezetéssel, majd a településsel szembeni elégedetlenséggé (DAHRENDORF, R. 1994).

A vizsgált falvak között négy olyan település van (Apátistvánfalva, Dunaszentmiklós, Fertőhomok és Villánykövesd) ahol nagy számban élnek nemzetiségek (9. ábra, 17. ábra - 4. sz. melléklet). A szlovén, horvát illetve német lakossággal rendelkező falvak nemzetiségének fontosságát a település fejlődése szempontjából már a statisztikai elemzés is alátámasztotta, a lakossági kérdőívezés pedig kiegészítette a hagyományápolás közösségkovácsoló hatásának hangsúlyosságával. A válaszadók döntő többsége jelezte ugyanis hagyományőrző rendezvények, falunapok meglétét a vizsgálatba vont településeken. A nemzetiségi falvakban népdalkör, tánccsoport müködik. Idősek, fiatalok egyaránt tartanak „összejöveteleket”, melyekről a szomszédos települések lakosainak is van tudomása.

A vizsgálatba vont falvak lakosai (és szomszédos településeik megkérdezettjei) sok esetben hiányolják az aprófalu infrastrukturális és intézményi feltételeinek meglétét (Klárafalva - Ferencszállás, Dozmat - Torony, Velemér - Magyarszombatfa, Szentgyörgyvölgy), valamint a munkalehetőséget. Mindkét tényezőre úgy tekintenek, mint a fejlődéshez szükséges feltételre. Szembetűnő azonban, hogy gyakran olyan hiányosságokról számolnak be a vizsgált falvak lakosai, melyek tekintetében a statisztikai elemzésben nincs nagy elmaradás az aprófalvak átlagához, vagy akár a falvak átlagához képest sem. Ilyen Klárafalván a közlekedési kapcsolatok további javítsa, vagy Alsómocsolád esetében a munkahelyteremtés is.

A felvett kérdőívek alapján elmondható, hogy a falvak marketingtevékenysége is igen eltérő. A vizsgált települések között van olyan falu (Csonkahegyhát), amelyik nem rendelkezik községi honlappal, annak ellenére sem, hogy körjegyzőségi központ. 
Feltünő a lakosság tájékozatlansága a falu médiaszereplését, kiadványait illetően, a lakossági válaszok jelentős része a „nem tudja” válaszlehetőséget jelölte meg az ide vonatkozó kérdések kapcsán a vizsgálatba vont településeken. A szomszédos falvak lakosainak a vizsgált települések média-, illetve marketingtevékenységére vonatkozóan alig van tudomása. A marketingtevékenység tehát ismét egy olyan tényező, amely nehezen mérhető statisztikai adatokkal, de a lakosság véleménye ismeretében is.
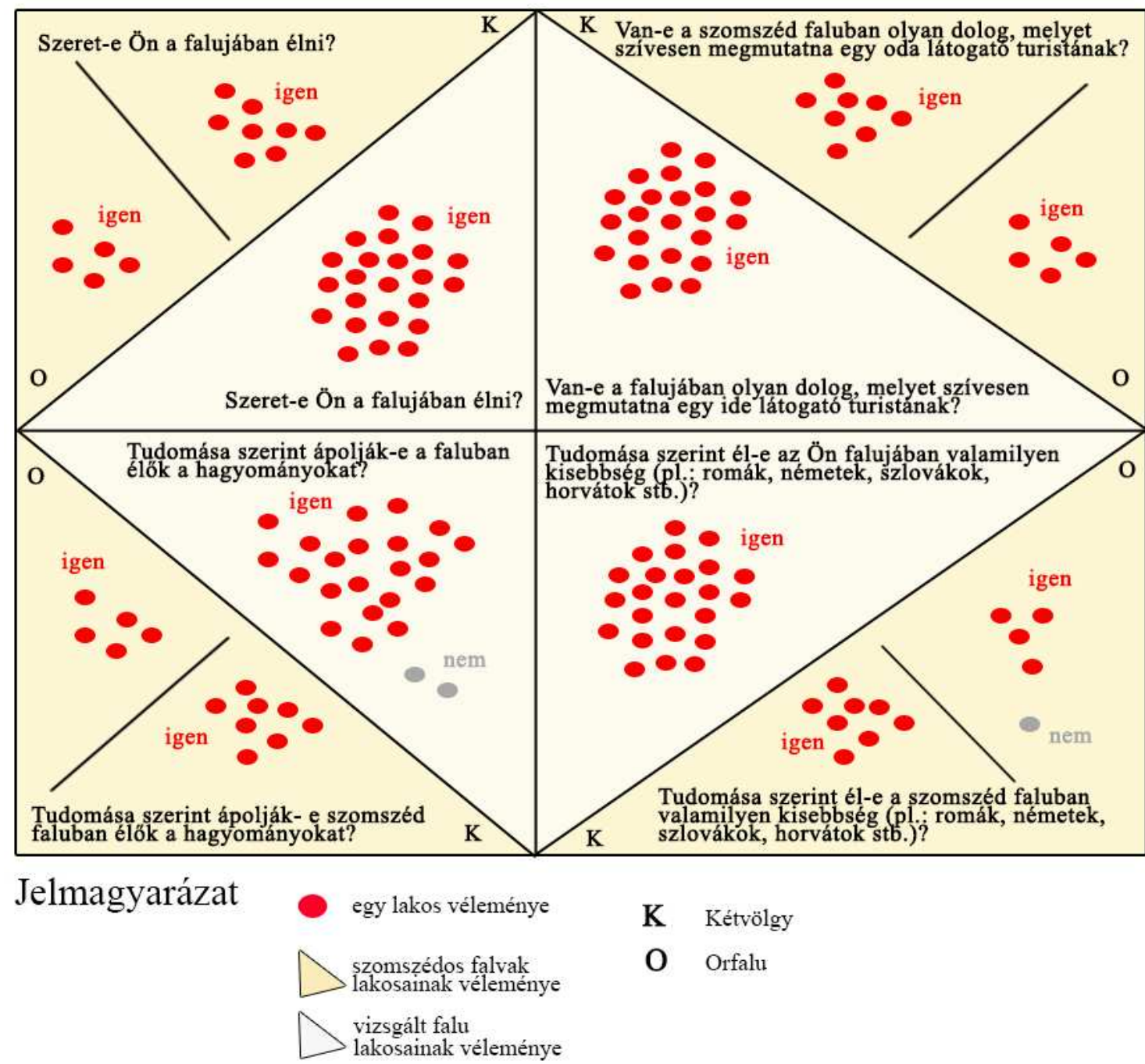

9. ábra. Apátistvánfalva és szomszédos településeinek véleménye az aprófalu nemzetiségi és turisztikai potenciáljáról

(Forrás: saját szerkesztés)

A polgármester és a lakosság kapcsolatát elemezve a válaszadók két csoportra oszthatók. A falvak egy részében a polgármester és a lakosság közti kapcsolat aktív. Ez a fejlődés egyik feltétele lehet (KING, D. S. 1990, D'ARCY, É. - GuISSANI, B. 1996). A polgármester, a képviselőtestület rendszeresen találkozik a falvak lakosaival. 
Falugyüléseken, közmeghallgatásokon lehet panasszal, javaslattal élni például Dunaszentmiklóson, vagy Fertőhomokon is. A települések másik csoportjánál a polgármester és a lakosság kapcsolata kimondottan rossz. Vagy azért, mert a polgármester nem vonja be a döntések előkészítésébe a lakosságot, mint például Veleméren, vagy azért, mert a lakosság oldaláról nem mutatkozik fogadókészség a döntések közös elökészítésére a polgármesterrel szembeni ellenszenv miatt (10. ábra). Ez utóbbira példa Apátistvánfalva és Villánykövesd.
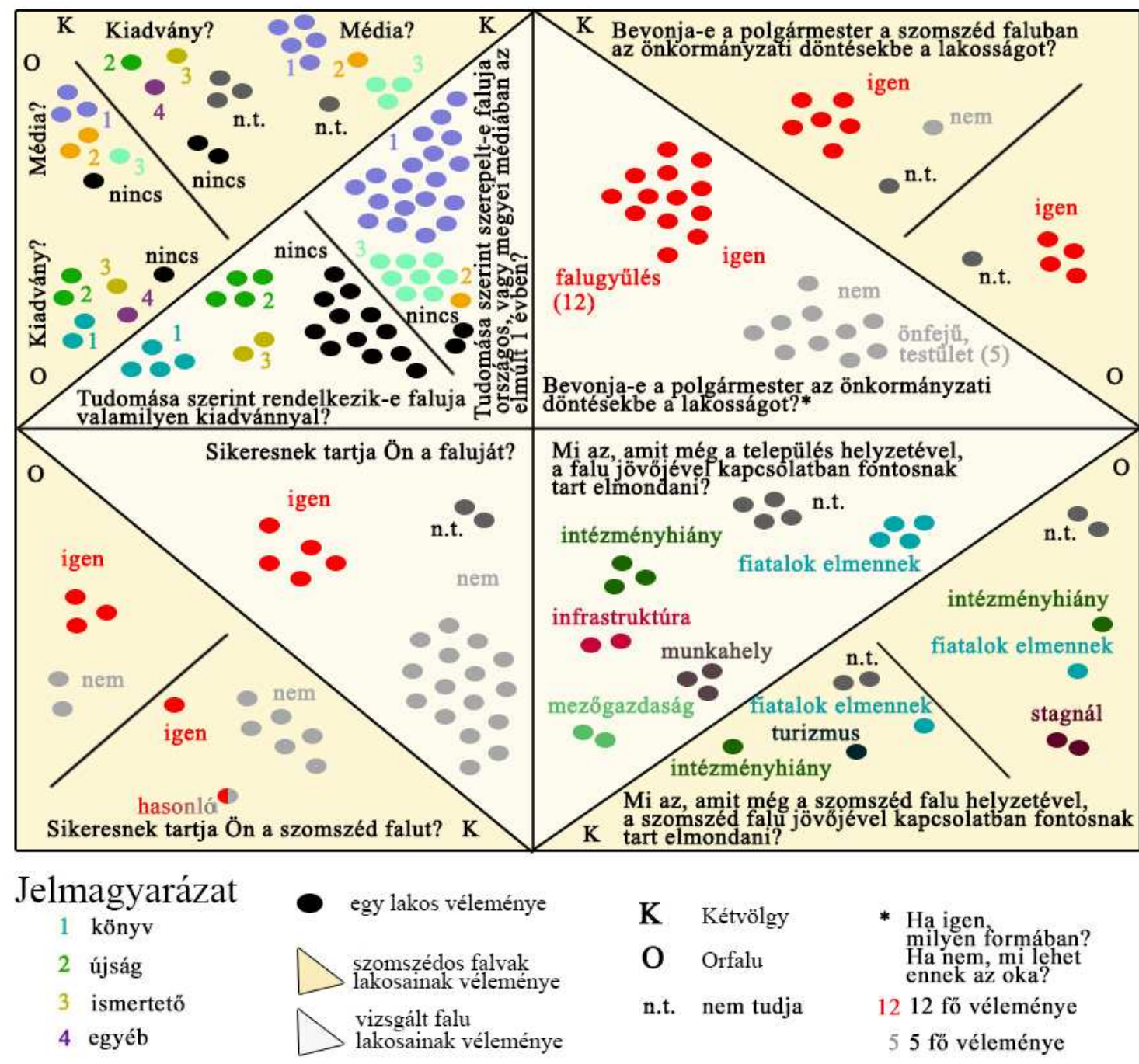

10. ábra. Apátistvánfalva és szomszédos településeinek véleménye a falu marketingtevékenységéről, a polgármester és lakosság viszonyáról, a sikerességről és a jövőképről

(Forrás: saját szerkesztés)

A fenti kérdések Apátistvánfalva példáján keresztül történő szemléltetése is alátámasztja azt, hogy a polgármester személye mennyire fontos és megosztó lehet a faluban. A lakosokat több vizsgálta aprófaluban is a falugyüléseken keresztül vonja be a 
település vezetése a döntések előkészítésébe. Azok a lakosok, akik nem elégedettek a döntéshozással, általában a polgármester és a képviselőtestület önfejüségével, lakosságot kizáró magatartásával elégedetlenek. Az ábrán is jól látható a marketingtevékenységre vonatkozó ismeretek hiánya, leginkább a szomszédos települések oldaláról, valamint a vizsgálatba vont falvak és szomszédos településeik lakosainak egy részénél a jövőt illető tanácstalanság is.

A környező települések közti helyzetet illetően (11. ábra) a vizsgálatba vont falvak lakosai arra vonatkozóan, hogy mely környékbeli falvakat tekintik saját településüktől sikeresebbnek illetve sikertelenebbnek igen differenciált válaszokat adtak. A megkérdezett falvakban az önmaguktól sikeresebbnek ítélt falvak között két olyan szerepelt (Bajánsenye, Csesztreg), amelyről több vizsgálatba vont falu lakossága is sikeresebbként nyilatkozott.

A vizsgált aprófalvak által sikeresebbnek tekintett környékbeli települések között aprófalvakat (pl. Kétvölgy, népességszám: 107 fö) és 500 fö feletti népességgel rendelkező településeket (pl. Torony: 1948 fö) egyaránt találunk. A vizsgált aprófalvak által felsorolt önmaguktól sikertelenebb falvak szinte kizárólag aprófalvak, azok közül is a legkisebbek (pl. Orfalu: 64 fö; vagy Pálfiszeg: 162).

A keleti országrészben elhelyezkedő aprófalvak lakosai településük sikerességét a környező falvakhoz mérve megosztottak. Tivadar lakosai úgy érzik, falujuk sokat fejlődött az elmúlt években, és a környező települések közül is tud néhány fejlesztéseket felmutatni (Túristvándi, Panyola, Penyige), ugyanakkor Klárafalva és Fony lakosai szinte valamennyi környező települést maguknál sikeresebbnek nevezték meg. Klárafalva esetében Deszk, Kiszombor és Ferencszállás, Fony esetében Hejce, Regéc, Mogyoróska, Vilmány és Vizsoly is a vizsgálatba vont aprófalutól sikeresebbnek ítélt falvak között szerepelt.

Annak eldöntése érdekében, hogy időben mennyire állandó egy, a szakirodalom által szük területen belül puha módszerek alkalmazása mellett sikeresnek nevezett, saját kutatás alapján statisztikailag és lakossági válaszok által is inkább fejletlennek nevezhető falu sikertelensége, 2013-ban újabb kutatást végeztem. Vagyis Fony környező települések közti helyzetét egy a Gazdaság- és Társadalomföldrajz Tanszéken zajlott szociálgeográfiai vizsgálat eredményeinek kiértékelésével is alátámasztom és megerősítem. 


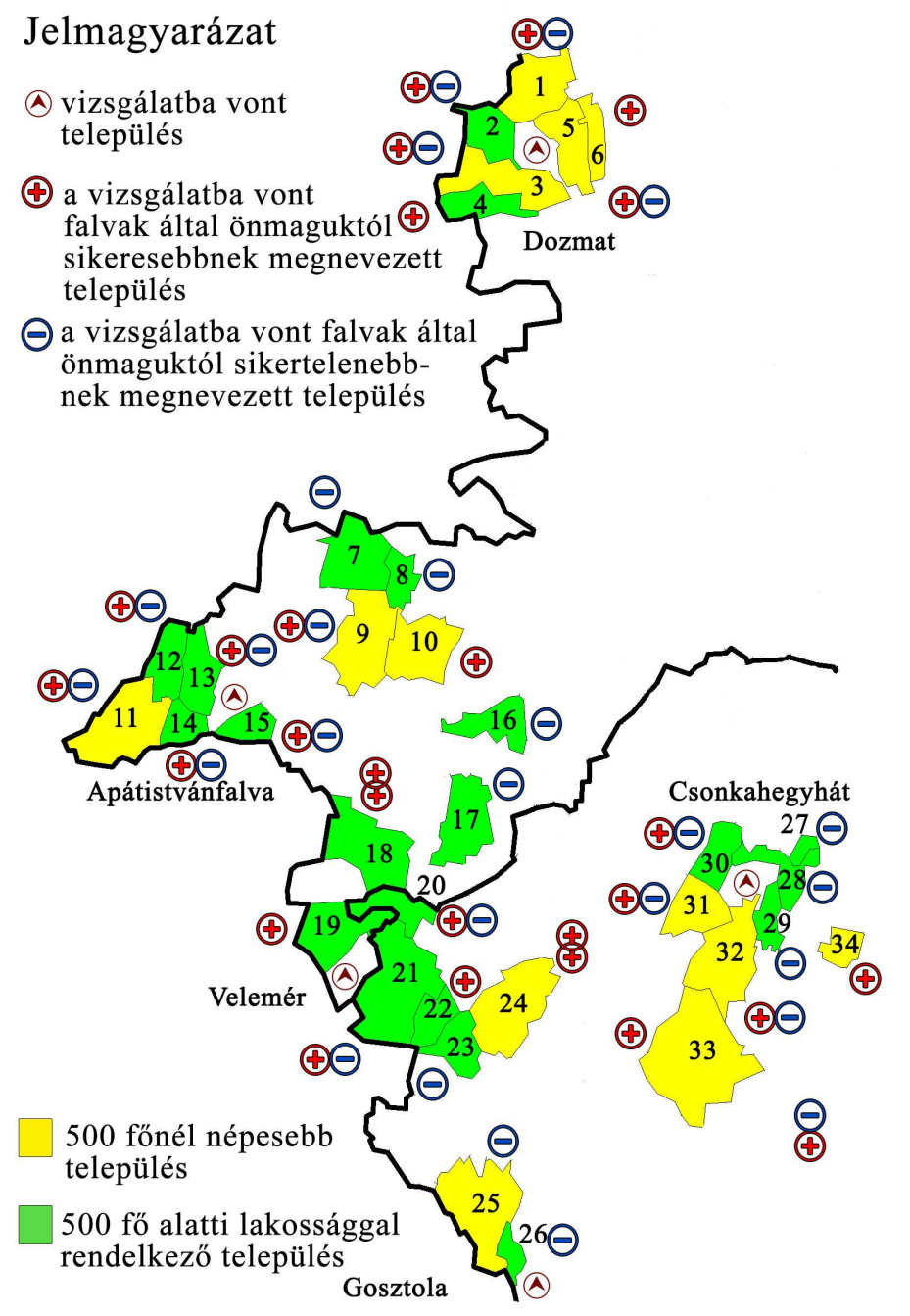

\begin{tabular}{|c|c|c|c|c|}
\hline Szám & Település neve & $\begin{array}{l}\text { Népesség- } \\
\text { szám } \\
\text { 2012. jan. 1. }\end{array}$ & $\begin{array}{c}\text { Sikeresebb, mint a } \\
\text { vizsgálatba vont } \\
\text { település*** }\end{array}$ & $\begin{array}{l}\text { Sikertelenebb, mint a } \\
\text { vizsgálatba vont } \\
\text { település** }\end{array}$ \\
\hline \multicolumn{5}{|c|}{ Dozmat } \\
\hline 1 & Bucsu & 586 & 3 & 1 \\
\hline 2 & Narda & 497 & 2 & 2 \\
\hline 3 & Felsöcsatár & 502 & 3 & 2 \\
\hline 4 & Vaskeresztes & 377 & 1 & 0 \\
\hline 5 & Torony & 1948 & 9 & 3 \\
\hline 6 & Sé & 1417 & 7 & 0 \\
\hline \multicolumn{5}{|c|}{ Apátistvánfalva } \\
\hline 7 & Rönök & 437 & 0 & 2 \\
\hline 8 & Vasszentmihály & 341 & 0 & 2 \\
\hline 9 & Csörötnek & 843 & 3 & 1 \\
\hline 10 & Rábagyarmat & 788 & 2 & 0 \\
\hline 11 & Felsöszölnök & 556 & 10 & 2 \\
\hline 12 & Alsószölnök & 367 & 4 & 1 \\
\hline 13 & Szakonyfalu & 354 & 2 & 1 \\
\hline 14 & Kétvölgy & 107 & 12 & 2 \\
\hline 15 & Orfalu & 64 & 5 & 12 \\
\hline 16 & Viszák & 246 & 0 & 1 \\
\hline 18 & Bajánsenye* & 455 & 1 & 0 \\
\hline \multicolumn{5}{|c|}{ Velemér } \\
\hline 17 & Nagyrákos & 275 & 0 & 1 \\
\hline 18 & Bajánsenye* & 455 & 3 & 0 \\
\hline 19 & Magyarszombatfa & 269 & 4 & 0 \\
\hline 20 & Magyarföld & 40 & 2 & 2 \\
\hline 21 & Szentgyörgyvölgy & 399 & 1 & 3 \\
\hline 22 & Márokföld & 45 & 1 & 0 \\
\hline 23 & Nemesnép & 123 & 0 & 1 \\
\hline 24 & Csesztreg* & 790 & 2 & 0 \\
\hline \multicolumn{5}{|c|}{ Gosztola } \\
\hline 25 & Rédics & 940 & 0 & 1 \\
\hline 26 & Lendvadedes & 27 & 0 & 2 \\
\hline \multicolumn{5}{|c|}{ Csonkahegyhát } \\
\hline 24 & Csesztreg* & 790 & 1 & 0 \\
\hline 27 & Dobronhegy & 137 & 0 & 1 \\
\hline 28 & Milejszeg & 347 & 0 & 1 \\
\hline 29 & Pálfiszeg & 162 & 0 & 7 \\
\hline 30 & Németfalu & 191 & 1 & 6 \\
\hline 31 & Kustánszeg & 509 & 9 & 4 \\
\hline 32 & Becsvölgye & 768 & 6 & 1 \\
\hline 33 & Nova & 819 & 1 & 0 \\
\hline 34 & Gellénháza & 1540 & 1 & 0 \\
\hline
\end{tabular}

11. ábra. A nyugati határmente vizsgált települései által önmaguktól sikeresebbnek illetve sikertelenebbnek megnevezett falvak köre (Forrás: saját szerkesztés) 
A 64 kérdésböl álló szociálgeográfiai kérdőív 50. kérdését használtam fel dolgozatomban: „Osztályozza az alábbi településeket ${ }^{21}$ az alapján, mennyire szimpatikusak Önnek! Egyáltalán nem szimpatikus (1), nem szimpatikus (2), szimpatikus (3), nagyon szimpatikus (4)” (3. sz. melléklet).

A kérdőívezés során az Erdőhorvátiban, Komlóskán, Háromhután, Mogyoróskán és Regécen felvett, 144 értékelhető kérdőív eredményei alapján különbözőségek figyelhetők meg a szociálgeográfiai kérdőívezés és a vizsgálatba vont falvakban zajlott kérdőívezés eredményei között (7. táblázat).

A disszertáció egyik fő logikai elemét adó lakossági kérdőívezés eredményei alapján a Fonytól sikeresebb és sikeretlenebb falvak közé döntően a falutól nyugatra elhelyezkedő települések kerültek. Ezzel szemben a 2013-as irányított válaszadás alkalmával a szociálgeográfiai kérdőívezés eredményei alapján a megkérdezett falvaktól keletebbre fekvő települések voltak szimpatikusabbak a helyi lakosok számára.

Regécet mindkét kérdőívezés során Fonytól sikeresebbnek ítélték a helyi lakosok. Mogyoróskát mindkét kérdöívezés során Fonytól sikertelenebb településként nevete meg a lakosság (8. kép - 8. sz. melléklet). Vagyis annak ellenére, hogy a hegység egyik vagy másik oldalán elhelyezkedő települések kevés információval bírnak a túloldali községekre, városokra vonatkozóan, ennek a két falunak a neve ismert a hegység mindkét oldalán.

Elmondható továbbá, hogy a megkérdezett települések mindkét kérdőívezés során jobban ismerik szükebb környezetük településeit, és az azokra adott válaszaik is differenciáltabbak. Szembetűnő az is, hogy a Fony környéki kérdőívezés során megkérdezett települések saját magukat minden esetben jobb helyzetűnek, szimpatikusabbnak találták társaiknál.

Annak érdekében, hogy a vizsglatba vont Fonyról érdemi információt nyerjek a környékbeli falvak közötti szimpatikussági helyzetet illetően, a szimpátia alapján nem minősített településeket 0-val kódoltam. Az 1-től 4-ig minősített települések értékeit összeadtam és a 0-tól különböző értéket tartalmazó cellák darabszámával osztottam. Így a szociálgeográfiai kérdőívezésbe bevont falvak felsorolt településekre adott szimpatikusságot tükröző pontértékei átlagolt, „nem tudja”, vagy „nem akar választ adni” válaszok torzító értékétől mentes pontértékeket kaptam. Ennek alapján a Fony

${ }^{21}$ A kérdőíves felmérés 5 helyszínen zajlott, és az alábbi településekről kellett a lakosoknak egy szimpatikussági skálát felállítani: Miskolc, Sárospatak, Sátoraljaújhely, Erdőhorváti, Tolcsva, Mogyoróska, Regéc, Háromhuta, Komlóska, Fony, Gönc, Encs, Makkoshotyka, Hercegkút. 
környéki kérdőívezés Fonyra vonatkozóan új információkkal nem szolgált, de Fony relatív fejletlenségét a környékkel való viszonylatában megerösítette.

A települések szimpatikussága

\begin{tabular}{|c|c|c|c|c|c|c|c|c|}
\hline & \multicolumn{6}{|c|}{ A települések szimpatikussága } & \multirow[b]{2}{*}{ Regéc } \\
\hline & & Miskolc & Sárospatak & Sátoraljaújhely & Erdőhorváti & Tolcsva & Mogyoróska & \\
\hline \multirow{6}{*}{$\begin{array}{c}\text { Válaszadó } \\
\text { telepüi- } \\
\text { lések }\end{array}$} & Erdőhorváti & 2,96 & 3,32 & 2,78 & 3,45 & 2,96 & 2,81 & 2,98 \\
\hline & Komlóska & 2,80 & 3,12 & 2,73 & 2,54 & 2,81 & 2,65 & 2,89 \\
\hline & Háromhuta & 2,64 & 3,41 & 2,67 & 2,90 & 3,40 & 2,35 & 3,15 \\
\hline & Mogyoróska & 3,00 & 3,30 & 3,20 & 3,11 & 3,40 & 3,90 & 3,80 \\
\hline & Regéc & 2,92 & 3,50 & 3,25 & 3,50 & 3,25 & 3,83 & 3,92 \\
\hline & Összes & 2,87 & 3,31 & 2,83 & 3,15 & 3,06 & 2,94 & 3,18 \\
\hline
\end{tabular}

\begin{tabular}{|c|c|c|c|c|c|c|c|c|}
\hline & & Háromhuta & Komlóska & Fony & Gönc & Encs & Makkoshotyka & Hercegkút \\
\hline \multirow{6}{*}{$\begin{array}{c}\text { Válaszadó } \\
\text { telepü- } \\
\text { lések }\end{array}$} & Erdőhorváti & 3,25 & 3,12 & 2,44 & 2,56 & 2,43 & 2,22 & 2,84 \\
\hline & Komlóska & 3,00 & 3,30 & 2,50 & 2,79 & 2,53 & 1,81 & 3,30 \\
\hline & Háromhuta & 3,86 & 3,33 & 2,83 & 2,40 & 2,47 & 2,95 & 2,95 \\
\hline & Mogyoróska & 3,20 & 3,22 & 3,50 & 3,30 & 3,60 & 3,29 & 3,50 \\
\hline & Regéc & 3,50 & 3,58 & 3,17 & 3,17 & 3,17 & 3,33 & 3,25 \\
\hline & Összes & 3,34 & 3,25 & 2,73 & 2,73 & 2,67 & 2,51 & 3,06 \\
\hline
\end{tabular}

\begin{tabular}{|l|l}
\hline & $\begin{array}{l}\text { szimpatikus település } \\
\text { kevésbé szimpatikus település } \\
\text { nem szimpatikus település }\end{array}$
\end{tabular}

7. táblázat. Erdőhorváti, Komlóska, Háromhuta, Mogyoróska és Regéc lakosságának véleménye 14 környékbeli település szimpatikusságáról

(Forrás saját számítás alapján saját szerkesztés)

$\mathrm{Az}$ erdőhorváti, komlóskai, háromhutai, mogyoróskai, és regéci válaszadók településenként összesített pontszámai alapján Fony a szimpatikussági skála közepén, alsó egyharmadában, a valamennyi településre összegzett átlagokat tekintve már egyértelmüen a szimpatikussági skála alsó egyharmadában foglalt helyet.

A Fony környéki kérdőívezés tehát megerősíti a vizsgálatba vont falvakban zajlott kérdőívezés lakossági válaszait, Fony környező településekkel összevetett helyzetét illetően. Azaz igazolja azt, hogy Fony nem kiemelkedő, nem sikeres az öt körülvevő településekhez mérten, és ez a helyzet az utóbbi években állandósulni látszik.

Mivel az empirikus vizsgálatok azt igazolták, hogy a megkérdezett, vizsgálatba vont települések lakosai a környékhez való viszonyítás során egy meglehetősen szük települési körben (aprófalu és nem aprófalu) gondolkodnak, így a vizsgálatba vont falvak sikerességi vizsgálatát kiegészítettem az aprófalvak közúton $20 \mathrm{~km}$-en belül elérhető környékbeli falvainak statisztikai vizsgálatával (ez 312 falut jelent), melynek eredményeit az empirikus eredményekkel vetettem össze.

A disszertáció tartalmi elemeinek tagolása során ennek a köztes vizsgálatnak az elhelyezése vitatható. Ugyanis a vizsált falvakat övező településeknek a statisztikai vizsgálata a szemléletmód alapján a „kívülről” való kutatás eredményei között kellene 
szerepeljen. Mivel azonban az a tény, hogy a vizsgált falvak szük környékét is érdemes kutatni, csak a lakossági kérdőívezés során igazolódott, így a dolgozat logikai íve véleményem szerint megtörne ennek a köztes vizsgálati lépésnek az átstrukturálásával. Ezért a környékbeli falvak statisztikai vizsgálatának eredményei jelen fejezetben kerülnek bemutatásra.

A környékbeli falvak fejlettségét tekintve (12. ábra) a Balaton vonala, mint térbeli elkülönítő elem, ismételten hangsúlyos szerepü. A Balaton környékén találjuk ugyanis a legfejlettebb falvakat, tőle északnyugatra, Dunaszentmiklós, Fertőhomok és Dozmat környékén szinte kizárólag jó összfejlettségü falvak fordulnak elő. Apátistvánfalva, Csonkahegyhát, Velemér, Gosztola, Romonya és Villánykövesd esetében mozaikos a környező települések fejlettsége. Az északkeleti országrész vizsgálatba vont aprófalvainak környékén döntően rossz fejlettségi adatokkal jellemezhető településeket találunk, mely elmaradottság korábbi vizsgálatomban is igazolást nyert (JÓzSA K. 2008). Az Alsómocsolád környéki falvak szintén fejletlenek.

Annak érdekében, hogy a környező települések fejlettségi adatainak ismeretében árnyaltabb képet adjak arra vonatkozóan, hogy a vizsgált falu fejlettsége befolyásolja-e a környező falvak fejlettségét és fordítva, a leíró statisztikában elfogadott területi autokorrelációt számítottam:

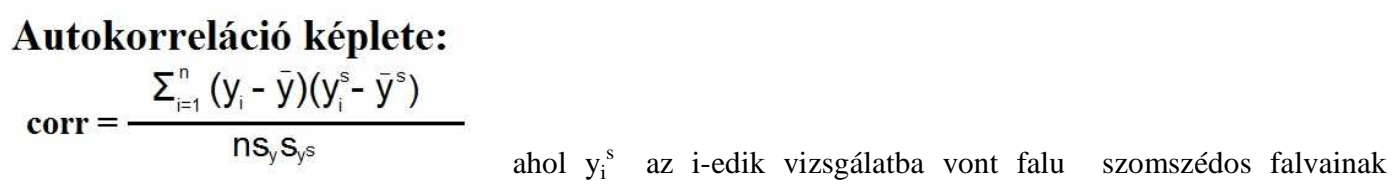
fejlettségi átlaga.

A területi autokorreláció adatai alapján elmondható (8. táblázat), hogy két aprófalu, Fony és Szántód kivételével a vizsgálatba vont falvak fejlettsége és a környékük fejlettsége között nincs sztochasztikus kapcsolat. A vizsgált falvak fejlettségének vagy fejletlenségének hatása a környező falvakra tehát csak abban az esetben mutatható ki, ha a vizsgálatba vont település az egyik legmagasabb vagy éppen legalacsonyabb fejlettségi értékkel rendelkezik. Fony 0,43-as korrelációs értéke a környező falvakkal laza, Szántód 0,84-es értéke szoros pozitív korrelációt jelent.

A korábbiakban leírt sikerességi tényezőkre vonatkozó megállapításaimat a területi autokorreláció értékeinek ismeretében a következőkkel egészítem ki. A sikeresnek tekinthető aprófalvak közvetlen környékén is relatíve fejlett falvakat, aprófalvakat találunk. Azokat a vizsgálatba vont településeket, amelyek fejlettségüket 
tekintve a faluállomány középső egyharmadában, vagy annak felső határához közel helyezkednek el, rendkívül szórt fejlettségü falvak veszik körül.

\begin{tabular}{|c|c|c|c|c|c|c|c|c|c|c|c|c|c|c|c|c|}
\hline & $\begin{array}{l}\text { Alsó- } \\
\text { mocso- } \\
\text { lád }\end{array}$ & $\begin{array}{c}\text { Apát- } \\
\text { istván- } \\
\text { falva }\end{array}$ & $\begin{array}{c}\text { Csonka- } \\
\text { hegy- } \\
\text { hát }\end{array}$ & $\begin{array}{l}\text { Doz- } \\
\text { mat }\end{array}$ & $\begin{array}{l}\text { Dör- } \\
\text { gicse }\end{array}$ & $\begin{array}{l}\text { Duna- } \\
\text { szent- } \\
\text { miklós }\end{array}$ & $\begin{array}{l}\text { Fertö- } \\
\text { homok }\end{array}$ & Fony & $\begin{array}{c}\text { Gosz- } \\
\text { tola }\end{array}$ & $\begin{array}{l}\text { Hegy- } \\
\text { magas }\end{array}$ & $\begin{array}{c}\text { Klára- } \\
\text { falva }\end{array}$ & $\begin{array}{c}\text { Romo- } \\
\text { nya }\end{array}$ & $\begin{array}{l}\text { Szán- } \\
\text { tód }\end{array}$ & $\begin{array}{c}\text { Tiva- } \\
\text { dar }\end{array}$ & $\begin{array}{l}\text { Vele- } \\
\text { mér }\end{array}$ & $\begin{array}{l}\text { Villány } \\
\text { kövesd }\end{array}$ \\
\hline Összfejlettség & 845,3 & 957,8 & 1027,8 & 1056,2 & 1054,7 & 1156,9 & 1082,9 & 737,4 & 1056,8 & 1066,1 & 861,2 & 923,7 & 1570,6 & 983,1 & 950,8 & 1013,3 \\
\hline \begin{tabular}{|l|} 
Környező \\
településeinek \\
összfeilettségi átlaga
\end{tabular} & 804,4 & 961,6 & 926,9 & 1063,4 & 1095,3 & 1050,6 & 1025,2 & 782,3 & 851,8 & 1104,9 & 1001,0 & 914,9 & 1086,1 & 829,1 & 898,5 & 814,3 \\
\hline \begin{tabular}{|l} 
Területi \\
autokorreláció \\
mértéke
\end{tabular} & 0,2296 & $-0,0179$ & $-0,0004$ & 0,0453 & 0,0541 & 0,1595 & 0,0566 & 0,4336 & $-0,0291$ & 0,0769 & $-0,1087$ & 0,0185 & 0,8436 & 0,0405 & 0,0251 & 0,0099 \\
\hline Sikeresebb (szám) & 2 & 39 & 19 & 25 & 28 & 30 & 25 & 41 & 0 & 21 & 45 & 29 & 15 & 24 & 13 & 26 \\
\hline \begin{tabular}{|l|} 
Sikertelenebb (szám) \\
\end{tabular} & 29 & 24 & 20 & 8 & 14 & 9 & 27 & 36 & 3 & 13 & 11 & 46 & 17 & 21 & 7 & 19 \\
\hline
\end{tabular}

8. táblázat. A területi autokorreláció értékei a vizsgálatba vont falvak összfejlettsége és környező falvaik összfejlettsége között

(Forrás: saját szerkesztés)

A relatív fejletlen vizsgált aprófalvak körül pedig általában fejletlen falvakat találunk. A fejlett aprófalvakat tehát általában fejlett, a fejletlen falvakat általában fejletlen környékbeli települések veszik körül. Ez a területi megoszlás nem a vizsgálatba vont települések és a környékbeli falvaik sztochasztikus kapcsolatán alapul azonban. A legsikeresebb és legsikertelenebb falvak esetében mutatható csak ki a környékbeli falvak fejlettségével/fejletlenségével korrelációs kapcsolat.

Érdemes összevetni a vizsgálatba vont falvak és azok szomszédos településeinek fejlettségi értékeit a lakossági kérdőívek eredményeivel is. A fenti táblázatból látható, hogy a statisztikailag sikeres falvak a környék településeihez mérten magasabb fejlettségi értékekkel jellemezhetők. Ez nagyrészt egybecseng a lakosság által megfogalmazott véleményekkel is. Vagyis azokban a falvakban, ahol a fejlettségi értékek meghaladják a környező települések fejlettségi értékét, a helyi lakosok is nagyobb számban neveznek meg a vizsgálatba vont falutól sikertelenebb településeket, mint sikeresebbeket.

A fent leírtak alapján a lakossági véleményekből kiderült, hogy a vizsgálatba vont falvak lakosai a környékbeli települések sikerességét illetően rendkívül vegyes képet alkotnak. Döntő szerepe a siker/sikertelenség fogalmaival jellemzett környékbeli falvakban a statisztikai elemzés eredményei alapján az ellátottság és az idegenforgalom - társadalom mutatócsoportoknak van. 


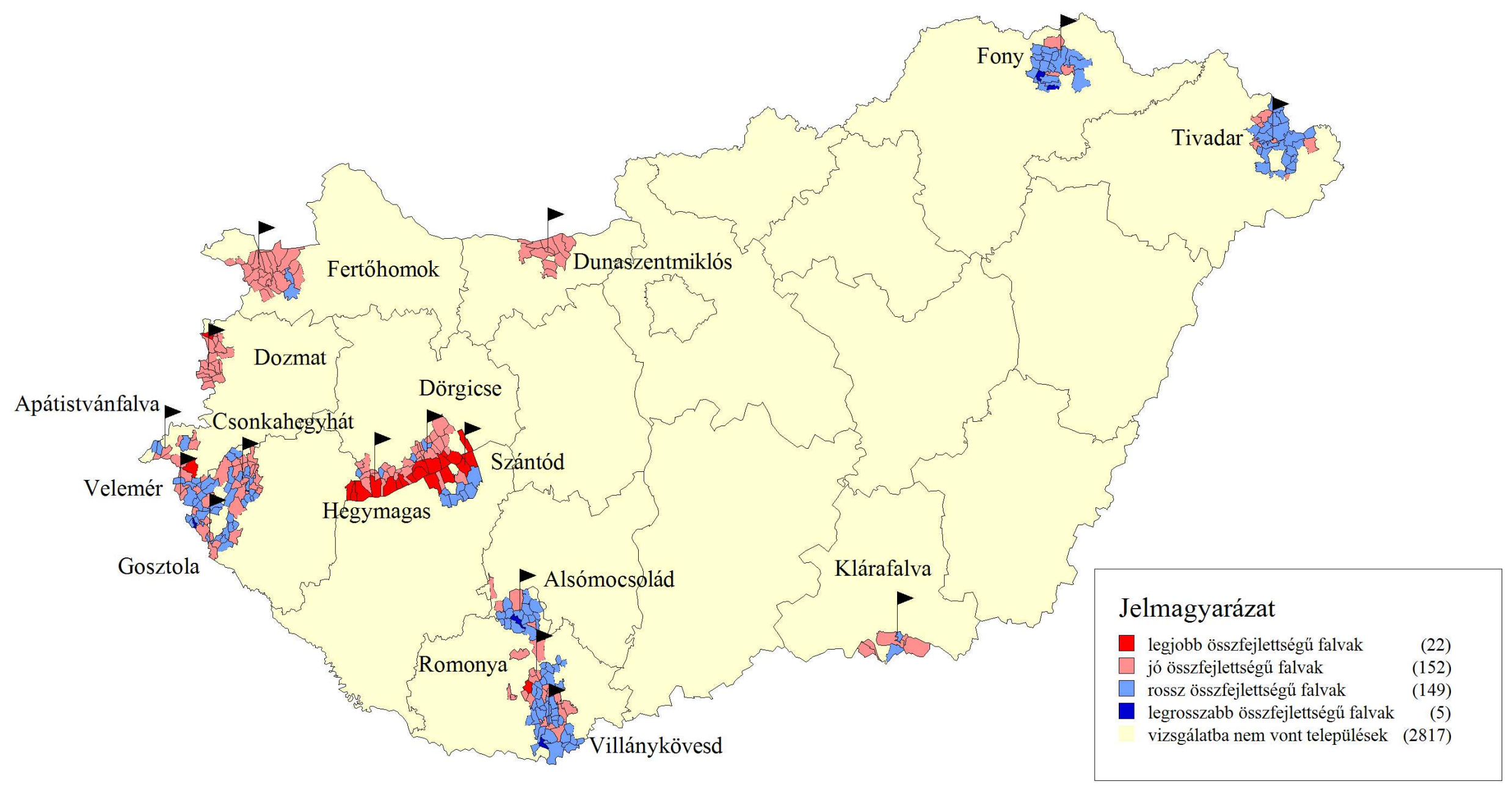

12. ábra. A vizsgálatba vont aprófalvak körül $20 \mathrm{~km}$-es körzeten belül elhelyezkedő falvak fejlettsége (Forrás: saját szerkesztés) 
A vizsgálatba vont települések által rosszabbnak ítélt környékbeli falvak ellátottság mutatócsoportjainak értékei térnek el negatív irányba a vizsgált aprófalvak értékétől, és ugyanezen mutatócsoport értékei térnek el pozitív irányba a sikeresebbnek ítélt környékbeli települések esetében. Más esetben, ha a társadalom és idegenforgalom mutatócsoport értékei együtt mozogva térnek el pozitív irányba, illetve negatív irányba a vizsgálatba vont falvak értékeitől, akkor a lakosság is sikeresebb illetve sikertelenebb faluról számolt be.

A fent leírtakat a könnyebb érthetőség kedvéért néhány példával is alátámasztom. Apátistvánfalva esetében a lakosság Felsőszölnököt és Kétvölgyet jelölte meg a falutól sikeresebb, Orfalut sikertelenebb településnek. Kétvölgy összfejlettségét tekintve valóban fejlettebb Apátistvánfalvánál, Felsőszölnök azonban nem. A mutatócsoportonkénti bontásban egyértelmü fejlettségbeli különbség Apátistvánfalva javára az ellátottság mutatócsoport értékeiben mutatható ki. Orfalu összfejlettsége közel azonos, mint Apátistvánfalváé, az ellátottság mutatócsoportjának értéke (Apátistvánfalva - 80, Orfalu - 66) viszont elmarad attól.

Fertőhomok esetében a lakosság Hegykőt nevezte meg egyértelmüen sikeresebb településként. Hegykő összfejlettsége és ellátottság (Fertőhomok - 221, Hegykő - 269) értéke is magasabb Fertőhomokénál. A lakosok által Fertőhomoktól egyértelműen sikertelenebbnek ítélt Hidegség és Fertőboz ugyanezen mutatócsoportjának értékei: Hidegség, 195, Fertőboz, 175.

Alsómocsolád esetében a lakosság által sikeresebb településként említett Bikal mind társadalom (92) mind idegenforgalom értéke (96) meghaladja a vizsgálatba vont falu társadalom (50) és idegenforgalom (77) értékét. A lakosság által sikertelenebbnek ítélt Gerényes (társadalom - 33, idegenforgalom 18) és Kisvaszar (társadalom - 37, idegenforgalom 20) településeknél szintén ennek a két mutatócsoportnak az együttes mozgása figyelhető meg negatív irányba a vizsgált falu értékeihez képest.

Annak ellenére, hogy a helyi lakosság a kérdőíves felmérés alapján inkább látja sikeresnek, mint sikertelennek települését, a kimondottan fejlődést prognosztizáló Gosztola mellett a települések többségében igen megoszlanak a vélemények a falu jövőjét illetően (13. ábra). Nagyjából fele-fele arányban vannak azok, akik fejlődést várnak a falujuktól az elkövetkező években (Szántód, Dunaszentmiklós, Fertőhomok, Hegymagas) és azok, akik szerint lényegi változás nem fog történni, illetve a falu rosszabb helyzetben lesz, mint amilyenben most van (Fony, Klárafalva, Alsómocsolád, Csonkahegyhát). 
A fejlődést azoknak a falvaknak a lakossága prognosztizálta, amelyek a statisztikai vizsgálatokban a legmagasabb fejlettségi értékek kapták. Stagnálásról, illetve a jövőt illető hanyatlásról azoknak a településeknek a lakossága számolt be, amelyek a statisztikai vizsgálatok fejlettségi rangsorában is hátul foglaltak helyet.

A sikerességi tényezők a „közösségi értékek” hangsúlyozása, „munkahelyek teremtése”, a „turisztikai adottságok kiaknázása”, „élhető település”, a „látványos fejlődés” „pályáznak”, ,jó a polgármester”, ,ápolják a hagyományokat” fogalmak köré szerveződnek. A lakosság által megfogalmazott turisztikai adottság, közösségi értékek és etnikumok, természeti sikerességi tényezők mellett nem kapnak viszont hangsúlyos szerepet olyan faktorok, mint a település szuburbán / dezurbán volta, a határhoz közeli fekvése, az, hogy a falu körjegyzőségi központ-e, valamint hogy a falu rendelkezik-e ipari, illetve mezőgazdasági funkcióval. Ennek oka vélhetően az, hogy a vizsgált falvak lakosai a szük környezetükben gondolkodnak, így pl. a település szuburbán volta, vagy a mezőgazdasági funkció azért nem lehet sikerességi tényező a helyi lakosok szerint, mert ezek a tulajdonságok a környező településeket éppúgy jellemzik, mint a vizsgálatba vont falvakat.

A körjegyzőségi központ/központi szerepkör, mint sikerességi tényező egy esetben volt a lakosság részéről is megnevezett, Apátistvánfalva esetében. Kétvölgy és Orfalu lakosai (Apátistvánfalva szomszédos települései) a templomba járás lehetőségét és a boltot Apátistvánfalván veszik igénybe, ezzel mutatva azt, hogy Apátistvánfalva valamiféle központi szerepet tölt be a környező települések között.

Alsómocsolád ipari funkciója pl. egyáltalán nem jelentkezik a fejlödés elősegítőjeként, sem a helyben, sem a szomszédos faluban felvett kérdőívekben, annak ellenére sem, hogy a Pick Szeged Zrt. egysége a helyi munkaerő foglalkoztatásán túl a környező települések munkaerejének egy részét is foglalkoztatni tudja.

A bortermeléssel foglalkozó Dörgicse (5. kép - 8. sz. melléklet), Hegymagas (10. kép - 8. sz. melléklet) és Villánykövesd ezen funkciója sem jelentkezik a sikeresség faktoraként, a falvakban és a szomszédos településken felvett kérdőívekben sem, Villánykövesden (16. kép - 8. sz. melléklet) negatív tartalommal töltődik meg, mondván ,annak jó, akinek van” ti. borospincéje, ami lakossági konfliktust is generál.

A statisztikai vizsgálat sikerességi tényezőit kiegészítve az aprófalvakban élők és a szomszédos települések lakosai is fontosnak tartják a környezet minőségét, a polgármesterekkel való aktív együttmüködést, az ellátottsági tényezők meglétét, a közösségi aktivitást és a nemzetiségek szerepét a település életében. 
Jelmagyarázat

- egy lakos véleménye
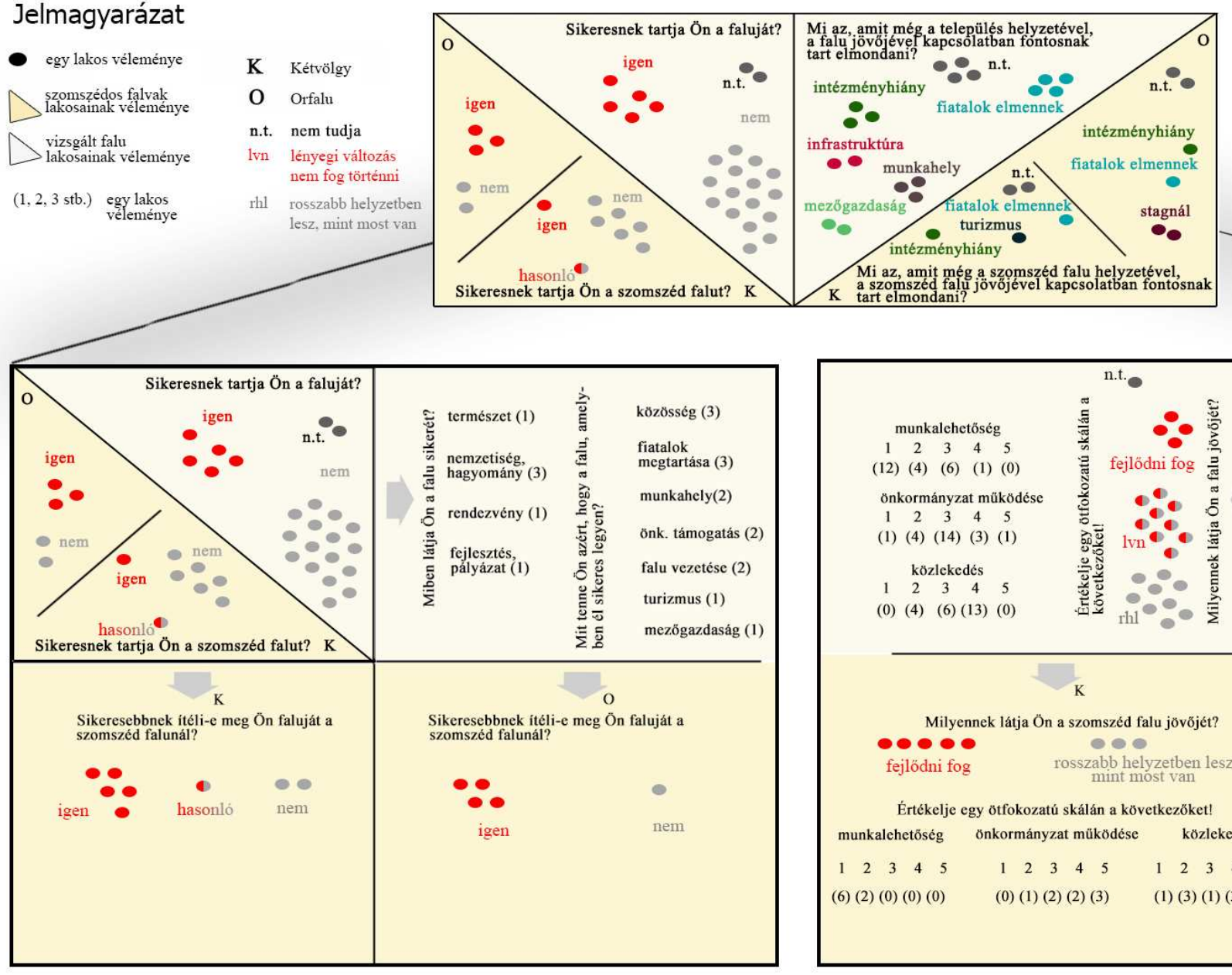

10. ábra (részlet)

$D \begin{gathered}\text { szomszédos falvak } \\ \text { lakosainak vélemenny }\end{gathered}$

$S_{\substack{\text { vizsgált falu } \\ \text { lakosainak vélemény }}}$

$(1,2,3$ stb. $) \begin{aligned} & \text { egy lakos } \\ & \text { veleménye }\end{aligned}$

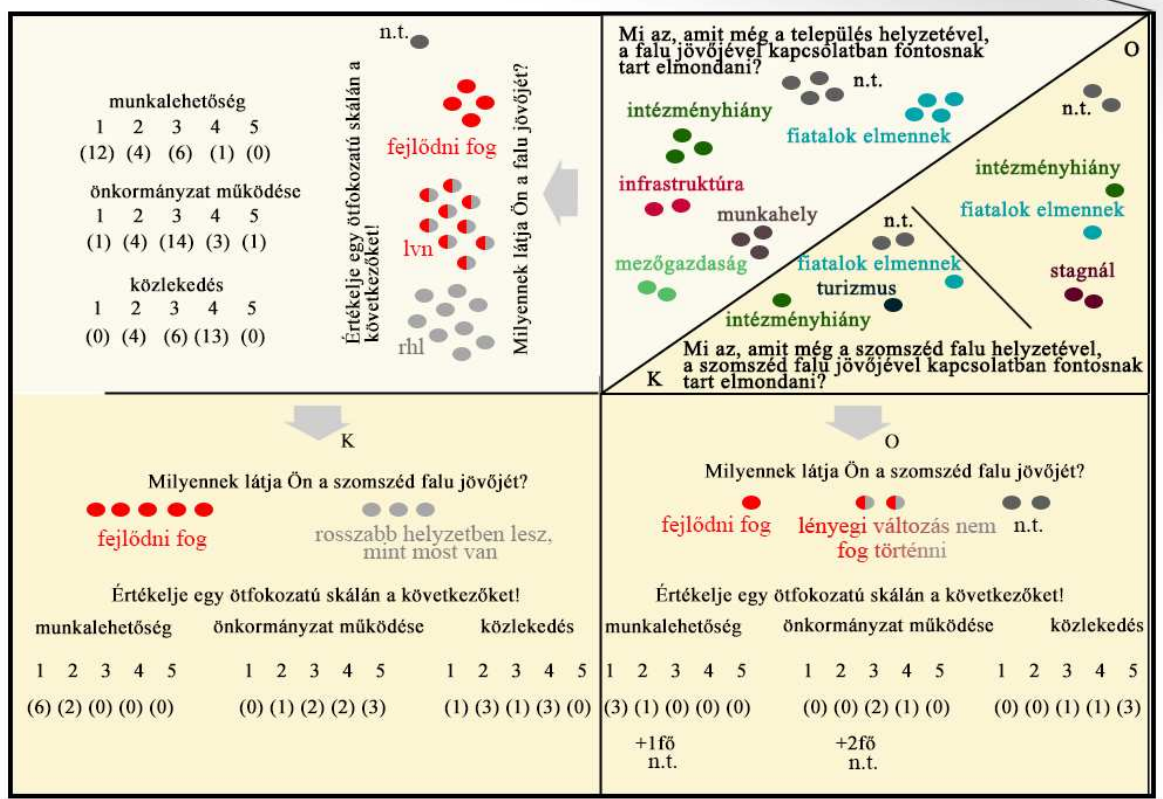

13. ábra. Apátistvánfalva és szomszédos településeinek sikerről és jövőről alkotott véleménye (Forrás: saját szerkesztés 


\subsection{A helyi elit által megfogalmazott sikerességi faktorok}

A vizsgálatba vont falvak polgármestereivel és a helyi elit tagjaival interjúkat folytattam (5. sz. melléklet), az interjúk megoszlása az alábbi módon alakult az egyes falvak között (9. táblázat).

\begin{tabular}{|c|c|c|c|c|c|c|c|c|}
\hline & $\begin{array}{l}\text { Alsómo- } \\
\text { csolád }\end{array}$ & $\begin{array}{l}\text { Apátist- } \\
\text { vánfalva }\end{array}$ & $\begin{array}{l}\text { Csonka- } \\
\text { hegyhát }\end{array}$ & Dozmat & Dörgicse & $\begin{array}{l}\text { Dunaszent- } \\
\text { miklós }\end{array}$ & $\begin{array}{l}\text { Fertö- } \\
\text { homok }\end{array}$ & Fony \\
\hline polgármester & $\mathrm{x}$ & $\mathrm{x}$ & $\mathrm{x}$ & $\mathrm{x}$ & & & $\mathrm{x}$ & $\mathrm{x}$ \\
\hline jegyző & & & & & & & & $\mathrm{x}$ \\
\hline $\begin{array}{l}\text { munkaszervezeti } \\
\text { vezető }\end{array}$ & & & & & & & & $\mathrm{x}$ \\
\hline \multicolumn{9}{|l|}{ óvodavezetö } \\
\hline egyesületi tag & & $\mathrm{x}$ & & & & $\mathrm{x}$ & $\mathrm{x}$ & \\
\hline ingatlanfejlesztő & & & & $\mathrm{x}$ & & & & \\
\hline \multicolumn{9}{|l|}{ közlekedési szakember } \\
\hline borász & & & & & $\mathrm{x}$ & & & \\
\hline
\end{tabular}

\begin{tabular}{|l|c|c|c|c|c|c|c|c|}
\hline & Gosztola & $\begin{array}{c}\text { Hegy- } \\
\text { magas }\end{array}$ & Klárafalva & Romonya & Szántód & Tivadar & Velemér & $\begin{array}{c}\text { Villány- } \\
\text { kövesd }\end{array}$ \\
\hline polgármester & $\mathrm{x}$ & $\mathrm{x}$ & & $\mathrm{x}$ & $\mathrm{x}$ & $\mathrm{x}$ & & \\
\hline jegyzö & & & & & & & & \\
\hline $\begin{array}{l}\text { munkaszervezeti } \\
\text { vezető }\end{array}$ & & & & & & & & \\
\hline óvodavezető & & & & $\mathrm{x}$ & & $\mathrm{x}$ & & \\
\hline egyesületi tag & & & & & & & & \\
\hline ingatlanfejlesztő & & & & $\mathrm{x}$ & & & & \\
\hline közlekedési szakember & & & $\mathrm{x}$ & & & & & \\
\hline borász & & $\mathrm{x}$ & & & & & & $\mathrm{x}$ \\
\hline
\end{tabular}

Interjúk száma

24

Az interjúk átlagos hossza:

$45 \mathrm{~min} 12 \mathrm{sec}$

A Remeteszőlősön készített próbainterjú eredményeit disszertációmban nem közlöm.

9. táblázat. A vizsgált településeken felvett interjúk megoszlása az egyes interjúalanyok között

(Forrás: saját szerkesztés)

A helyi elit tagjaival folytatott interjúk alapján elmondható, hogy vizsgált aprófalvak vezetői szinte kivétel nélkül több cikluson keresztül polgármesterek a településükön. A települési vezetők egy része a polgármesteri jelölés előtt semmilyen kapcsolatban nem volt az önkormányzattal, önkormányzatisággal. Alsómocsolád polgármestere mezőgazdasági pilótaként, gépkocsivezető-oktatóként került a polgármesteri székbe, de Fertőhomok polgármestere például kertészmérnök, Gosztola polgármestere vendéglátós, szállodatulajdonos volt a polgármesteri jelölés időszakában.

A polgármesterek másik fele már a jelölésük előtt is kapcsolatban volt a település önkormányzatával. A csonkahegyháti polgármester hivatalsegédként, élelmezésvezetőként dolgozott, képviselői tisztséget látott el, majd 2006 óta tölti be a 
polgármesteri tisztséget ${ }^{22}$. A dozmati polgármester művelődési ház vezetőként, képviselőként dolgozott korábban, és ugyancsak képviselő volt a fonyi, hegymagasi, romonyai polgármester is. A vizsgált aprófalvakban is megfigyelhető, hogy a lakossági választók általában a magasabb végzettségü polgármestereket preferálják, valamint, hogy a polgármesterek gyakran tagjai valamilyen civil szervezetnek. Az aprófalvak polgármestereivel folytatott interjúkból kiderül továbbá, hogy a lakosság által közvetlen módon választott, államigazgatási jogköröket gyakorló településvezető meghatározó eleme egy település életének, mint azt a szakirodalom nagyobb lélekszámú települések esetében már igazolta (Bocz J. 1996, Bocz J. 2004).

Eltérő életpályájuk ellenére egy tulajdonság közös a megkérdezett polgármesterekben, mely szerint nem ők akartak polgármesterek lenni, család, barátok, a falu lakosai keresték meg őket azzal, hogy induljanak a polgármesteri választáson, ( 1 . idézet, 2. idézet, 3. idézet, 4. idézet) és be is váltották a hozzájuk füzött reményeket, hiszen többen közülük már az 1990-es évek eleje óta folyamatosan ellátják ezt a tisztséget.

1. idézet: „Eszem ágában nem volt, hogy polgármester legyek. Megkerestek engem, hogy kellene menedzselni [ti. a falut] ." - Romonya polgármestere

2. idézet: „Hazudnék, ha azt mondanám, hogy volt ilyen indíttatásom.” Fertöhomok polgármestere

3. idézet: „Családi ösztönzésre indultam az elsö önkormányzati választásokon a polgármesteri címért." - Alsómocsolád polgármestere

4. idézet: „Tarpán dolgoztam az önkormányzatnál 24 évig. Többen megkerestek azzal, hogy miért nem a saját településemen tevékenykedem?” - Tivadar polgármestere

A polgármesterek többsége egyetért abban, hogy a települési vezetőnek nem csak a hivatalban van dolga, minden területen helyt kell állni (5. idézet), a legtöbbjük igyekszik nyitott fülekkel járni, és tenni a dolgát a képviselőtestülettel együtt (6. idézet). $\mathrm{Az}$ aprófalvakban felvett interjúk eredményei is alátámasztják a nyugat-európai kutatások azon megállapításait, hogy nem a bürokratikus „governing”, sokkal inkább a „governance”, azaz a társadalmi szféra felé fordulás módszerével lehet - föleg egy kistelepülésen - hatékonyan irányítani (JoHN, P. 2001, LE GALES, P. 2002, DENTERS, B. R. - LAWRENCE, E. 2005). A lakosság felé forduló, lakossági véleményt kikérő, a

\footnotetext{
${ }^{22}$ A 2006-os választások idején több médiumban megtalálható volt az a hír, amely egy 500 főt sem számláló kistelepülés - Csonkahegyhát - 10 polgármesteri jelölésével foglalkozott. A választásokra végül 9 jelölt maradt, végül két jelölt közötti szavazategyenlőség után, megismételt választáson 4 jelölt közül választotta meg a község lakossága Csonkahegyhát akkori és jelenlegi polgármesterét.
} 
községért tenni akaró polgármesteri magatartás azt eredményezte, hogy a megkérdezett polgármesterek többsége a helyén maradt a 2010-es választások után is. A statisztikailag legfejlettebb aprófalvak közül továbbra is polgármester maradt Dunaszentmiklós, Fertőhomok és Szántód polgármestere. A többi vizsgálatba vont aprófalu közül Alsómocsolád, Csonkahegyhát, Dörgicse, Fony, Gosztola, Klárafalva, Romonya, Tivadar és Velemér polgármesterei a 2010-es ciklustól szintén ellátják a polgármesterei feladatokat.

Az aprófalvas területeken egyébként is tradicionálisan magas a választássokkal kapcsolatos érdeklődés és választási hajlandóság, a dél-baranyai, csereháti, zempléni, szatmári területeken és északnyugat Magyarországon kimondottan magas aktivitás figyelhető meg (BóDI F. - BóDi M. 2011).

$\mathrm{Az}$ aprófalvak másik részében viszont a polgármesterekkel szembeni elégedetlenség már a kérdőíves adatfelvétel idején is érzékelhető volt. Legerőteljesebben ez az ellenszenv a polgármester személyét és tevékenységét illetően Villánykövesden volt érzékelhető. A lakossági kérdőívek válaszaiből egyértelmüsíthető volt a polgármesterrel és a képviselőtestülettel szembeni elégedetlenség. A polgármestert a 2010-es ciklusra le is váltották, mint ahogyan a 2010-es ciklustól kezdve új polgármester került a településvezetés élére Apátistvánfalván, Dozmaton és a statisztikailag egyébként legmagasabb összfejlettséggel rendelkező települések közé került Hegymagason is.

5. idézet: „(...) egy vidéki település polgármesterének többrétü a dolga. Azzal is foglalkozni kell, ha egy ajtókilincs tönkrement. Éjszaka csörög a telefon, akkor menni kell”. - Fony polgármestere

6. idézet: „Kistelepülésen az ember annyira jár nyitott fülekkel, hogy nagyjából érezheti azt, hogy mi az emberek igénye”. - Fertöhomok polgármestere

Valamennyi vizsgálatba vont településsel kapcsolatban elmondható, hogy a megélhetési források korlátozottak. Fő foglalkoztató legtöbb helyen az önkormányzat, melyre jellemző, hogy a szociális feladatok ellátásához a településre érkező állami normatívát és más forrásokat egymással kombinálva használja fel, mint ahogy azt a szakirodalmak egy része ismerteti (VIRÁG T. 2009). Erre azért van szükség, hogy a lakosság nagy részét érintő foglalkoztatási nehézségeket a falu vezetése helyben megoldja. 
Az önkormányzat foglalkoztatja a legtöbb lakost Tivadaron és Csonkahegyháton is. Előbbiben önkormányzati tulajdonban és üzemeltetés alatt áll az a szabad strand, mely idényjelleggel, nyáron biztosít leginkább megélhetést a falu lakosai számára. A strand jelentősége azért is fontos, mert a vállalkozási hajlandóság Tivadaron, csakúgy, mint a kistelepülések nagy részében igen alacsony. A faluban mindössze két vállalkozás müködik, egyikük mezőgazdasággal foglalkozik, intenzív gyümölcsöst tart fenn, másikuk tüzép telepet üzemeltet, így az iparüzési adó nem növeli érdemi mértékben a falu bevételeit. A nyugati országrészben, Csonkahegyháton is alacsony az iparüzési adó, amit kisszámú vállalkozás - vendéglátó egység, kocsma, bolt - autószerelő mühely termel ki, melyek általában csak önmaguk munkájáról tudnak gondoskodni, további alkalmazottak foglalkoztatására nincs lehetőség (7. idézet).

Számos interjú során előkerült a kisfalvakat súlyosan érintő TSZ bezárások, felszámolások, átalakulások kérdésköre, legerőteljesebben is Csonkahegyháton. A termelőszövetkezetek megszünése előtt a mezőgazdasági üzemek sokat tudtak tenni a foglalkoztatásért, ma erre azonban már nincs lehetőség (BELUSZKY P - SiKOS T. T. 2007).

Az interjúk során is megfigyelhetö volt az a jelenség, melyet korábban TSZ dolgozókkal folytatott interjúk eredményeiből írtak le a kutatók, vagyis hogy a kollektivizálás erőszakos volta elhomályosulni látszik. Az azonban megjegyzendő, hogy nem az 1950-es, sokkal inkább az 1980-as évek viszonylagos jólétére gondolnak vissza a megkérdezettek, mint ahogy azt más szakirodalmak is leírták (LOVASS K. A. 2006).

Nem sokkal van előnyösebb helyzetben Hegymagas mezőgazdasági vonatkozások tekintetében, annak ellenére sem, hogy a községben a borbevételek plusz jövedelmet jelentenek a falu lakosai számára, valamint a szőlőtermesztéshez (8. idézet) kapcsolódó turizmussal is foglalkozik pár család. Az önkormányzatnak a pincékkel rendelkezők építményadója ugyan jelent bevételt, de helyi foglalkoztató itt sincs. A kiskereskedelmi üzletek is hiányoznak, mely jelenséget a közeli Tapolcán lévő bevásárlóközpontok idézik elő (9. idézet). Villánykövesden (10. idézet) és Dörgicsén (11. idézet) is csak tisztes megélhetést jelent a borászat.

7. idézet: „Ezek csak saját maguk dolgoznak.” - Csonkahegyhát polgármestere

8. idézet: „(...) önálló vállalkozóként dolgozom, sok munkám van a szölészetben.”

- borász szakember (Hegymagas)

9. idézet: „Az emberek keresik, mi hol olcsó, ott vásárolnak.” - Hegymagas polgármestere

10. idézet: „(..) egész évben nyitva vagyunk, de a turistákat jobban érdekli a 
pincesor fényképezése, mint a borok megvásárlása.” - borász szakember (Villánykövesd)

11. idézet: „(...) inkább vonzza az embereket a Balaton, mint a boraink.” - borász szakember (Dörgicse)

A szuburbán aprófalvak helyzete a foglalkoztatás kapcsán előnyös, ezek lakosságszámuk növekedését tekintve a településlisták élére is kerülhetnek kimagasló vándorlási nyereségük következtében, erre vonatkozóan is található számos példa a szakirodalomban (BAJMÓCY P. - JózSA K. - PÓCSI G. 2007).

A városok közelsége a jó megközelíthetőség mellett az átrétegződésre is hat a településeken (KISS J. P. 2008). Romonyán helyben mindössze egy presszó, kocsma, kőfaragó mühely üzemel, viszont munkalehetőségben mégsincs hiány, mivel Pécs közelsége segítséget jelent a munkakeresésben, Pécs felszívja a romonyai munkaerő jelentős hányadát. A szintén szuburbán Dozmat lakosai számára Szombathely közelsége jelent munkaalkalmat, a vállalkozások száma itt is magas, melynek hátterében az igen alacsony iparüzési adó áll (12. idézet). Ez az alacsony iparüzési adó előremozdítja a szuburbán településeken a vállalkozások számának növekedését, és elindít olyan folyamatokat, melyek kapcsán a szuburbán területeken megfigyelhető egy nem lakó funkció felé való elmozdulás (TimÁr J. 1999, BAUMONT, C. - ERTUR, C.- LE GALlo, J. 2001).

12. idézet: „A vállalkozók nagy része segítö szándékú. Ha olyan munka van, amit el tudnak végezni, akkor csekélyebb összegért megteszik.” - Dozmat polgármestere

Igen sajátos Gosztola helyzete, ahol a fö - és gyakorlatilag egyetlen foglalkoztató a település polgármesterének lánya által vezetett Gosztola Gyöngye szálloda (9. kép - 8. sz. melléklet). A szálloda megtelepedése a faluban a munkahelyteremtés mellett a telekárakban jelentett szembetűnő változást. Gosztolán a szálloda megépítése előtt 50.000 forintért lehetett házhelyhez jutni, a szállodaépítésnek köszönhetően azonban felmentek a telekárak. Az első években az árak négyszeresére növekedtek, megközelítőleg 200.000 forintért lehetett házhelyet venni. Ma már 6-7 millió forint az átlagos telekár, de akár 10-12 millió forintot is elkérnek egy házhelyért.

Általánosságban elmondható, hogy a megkérdezett polgármesterek legtöbbje nem szívesen beszél a településen jelentkező konfliktusokról. Az interjúk során a faluban jelentkező konfliktusok iránt érdeklődve a válasz általában nemleges, viszont az interjúk 
további kérdései kapcsán a polgármesterek beszámolnak korábban nem említett, de a falu életét nagymértékben befolyásoló konfliktusokról.

A vizsgálatba vont aprófalvak között zavartalannak ítélik meg a lakosság egymással és a polgármester személyével kapcsolatos viszonyát a statisztikailag fejlett és a lakossági vélemények szerint is sikeres Hegymagas (13. idézet) és Fertőhomok polgármesterei (bár könnyen kialakuló lakosok közötti konfliktusforrásokra ők is felhívják a figyelmet). A konfliktusmentesség eléréséhez szükséges az összetartás, összefogás a dozmati polgármester szerint (14. idézet), de hasonlóan vélekedik Csonkahegyhát polgármestere is. Szintén konfliktusmentesnek ítéli meg faluját Gosztola polgármestere, bár annak okaként nem a közösség egymást segítő magatartását nevezi meg, hanem a lakosság anyagi jólétét (15. idézet).

13. idézet: „Probléma néha van, de megoldjuk házon belül.” - Hegymagas polgármestere

14. idézet: „Az emberek nagy része a megoldásra törekszik, nem a széthúzásra.

Egyfelé húz a szekér." - Dozmat polgármestere

15. idézet: „30-40 milliós villák vannak, ott nincs gond a lakossággal.” Gosztola polgármestere

Az interjúk során kiderült az is, hogy van olyan vizsgált aprófalu is, ahol nyílt konfliktus jelentkezik, így fontosnak tartom definiálni az értekezésben is ezt a fogalmat. A továbbiakban tehát konfliktus alatt több települést érintő érdekellentétet, valamint társadalmi, gazdasági, közigazgatási és politikai érdekkülönbözetet értek, egyetértve számos más kutatóval (Boulding, K. 1963, DAHRENDORF, R. 1994, GidDENS, A. 2002).

A fent említett konfliktusok közül a lakossági konfliktus alapját az adja, hogy az egyének önmagukban, családtagjaikban és közeli ismerőseikben bíznak, a többi körülöttuik lévő emberben nem, vagy csak ritkán (FUKUYAMA, F. 2007). Így leggyakoribb lakossági konfliktusforrásként az őslakosok mellé betelepülő új lakosság jelentkezik. Az ún. „gyütt-ment” szindróma jellegzetessége, hogy egyrészt az őslakos népesség nem szívesen fogadja be a betelepülőket, másrészt a betelepülők sem érzik magukénak a falut.

Közép- és Nyugat-Dunántúlon a települések 16-18\%-ában kimutatható a települési szegregációnak az új lakosok elkülönülését eredményező formája (KOPASZ 
M. 2004) ${ }^{23}$, míg legmagasabb a konfliktusok aránya a Közép-Magyarországi régióban (KovÁCS K. 1999, VÁRAdI M. 1999).

A vizsgálatba vont falvakban folytatott interjúk eredményeiből kiderül, hogy a lakossági konfliktus legerőteljesebben Romonyán jelentkezett. Annak ellenére, hogy a település nagyon toleráns és elfogadó lakosokból áll, gondot okoz az újonnan betelepülők integrációja (16. idézet) a polgármester és a helyi óvoda vezetője szerint is. A település életébe azok az új lakosok kapcsolódnak be, akik a foghíjas telkeken építkeztek, és azok is jobban részt vesznek a település életében, akik önkormányzati bérlakásból kikerülve kezdtek el építkezni. A Barackos lakópark lakói viszont nem keresik a kapcsolatot a helyi őslakosokkal.

A kistelepüléseken belüli két alapjában konfliktusmentes település vezetője a munkanélküliséghez kötődő nehézségeket hangsúlyosan említi, nem a településeket jelenleg érintő konfliktusként, hanem olyan gondok forrásaként, amelyek nem megfelelö módon kezelve rövidesen konfliktushoz vezethetnek.

Hegymagas polgármestere szerint több faluban a gondot az jelenti, hogy nehéz megfelelő és értelmes munkát találni a munkanélküliek számára (17. idézet), csakúgy, mint Fertőhomokon. Ez utóbbi településen az emberek - ahogyan a polgármester fogalmaz - mindig is öntevékenyek voltak, de az elmúlt években egyre többen szorulnak rá itt is a segélyezésre, melyet nem minden lakos néz jó szemmel (18. idézet).

Hasznosnak találnám a külföldi szakirodalomban elfogadott „öko-szociális munka" fogalomkörének és jellemzőinek adaptálását, alkalmazását, mely szerint a szociális munka jelenleg is meglévő társadalmi funkciói mellett lehetőséget adna arra, hogy a benne részt vevő lakosok javítsák környezetüket, ezáltal a társadalmi jólét feltételei megteremtődjenek, élhető környezet alakuljon ki (LÁNYI A. 2007., MARY, N. L. 2008.).

16. idézet: „Nehéz beintegrálni az ide költözöket. Eléggé elzárkózottak. (...) [legtöbbjük] távirányítóval kinyitja a kaput, (...) [majd a] kapu bezárul.” Romonya polgármestere

17. idézet: „Megpróbálunk úgy segíteni, hogy alkalmazzuk öket felváltva. Annak nincs értelme, hogy itt üldögéljenek. Rájuk kell figyelni, és olyan munka kell, ami leköti öket." - Hegymagas polgármestere

18. idézet: „Az a fajta hangulat, amit szerintem tévesen sugallnak, hogy mire van jogod, és miért fordulhatsz az önkormányzathoz, nem jó. (...) a segélyért dolgozzon meg valaki, ha tud." - Fertöhomok polgármestere

\footnotetext{
${ }^{23}$ A lakossági konfliktusok e formája a 2000-5000 fős településeket érinti leginkább, de az 1000 fő alatti településeken is több, mint $10 \%$-ban okoz gondot az öslakosok és a betelepülők közti konfliktus.
} 
Az interjúk adatai alapján a helyi elit tagjai tehát sikerességi tényezőnek nevezték meg a polgármester aktivitását a település életében, a falun belüli konfliktusmentességet, és azt, hogy a lakosság munkaalkalma biztosított legyen akár helyben, akár napi, vagy heti ingázással elérhető környékbeli településen.

Legfőbb megállapítása a megkérdezett polgármestereknek a pályázati lehetőségek kapcsán az volt, hogy nem minden esetben arra pályáznak, amire feltétlenül szüksége van a falunak, hanem arra, amire lehet. A legtöbb pályázati forrást a vizsgálatba vont kistelepülések az infrastruktúra fejlesztésére, településkép formálásra, az intézmények állagának megóvására, felújítására igényelték.

A legmagasabb pályázati hajlandóság a statisztikai és lakossági felmérésben sikeres aprófalvakban mutatkozott. Hegymagas polgármestere a Szent-György hegy környéki útpályázatról, Fertőhomok polgármestere kerékpárút pályázatról (19. idézet) számolt be. Gosztola polgármestere a pályázatokkal kapcsolatban útberuházást, a polgármesteri hivatal és ravatalozó felújítását, internet elérés kiépítését, Dozmat polgármestere játszótér létesítését (20. idézet) ismertette. Csonkahegyhát polgármestere csatornapályázatról, orvosi rendelő felújításról, bővítésről, Tivadar polgármestere kultúrház felújításról, tanösvény kialakításról nyilatkozott.

19. idézet: „Kerékpárútra pályázunk. Energiatakarékosabb üzemeltetés kellene, de olyan pályázat, amelyben ezzel lehetne foglalkozni, olyan nincs." Fertőhomok polgármestere

20. idézet: „(...) játszótérre pályázunk, mert arra lehet.” - Dozmat polgármestere

A települések egy része összefogva igyekszik pályázati forrásokhoz jutni. A közös tevékenységet a LEADER, az Európai Unió egyik programja is ösztönzi, mely a leszakadó, elszigetelődő térségek felzárkóztatására jött létre, a helyi civil és vállalkozói szféra mozgósítása céljából (KovÁCs T. 2000, RAY C. 2000, CsATÁRI B. 2004). A Zala megyei falvak élen jártak a települések közti együttmüködés kialakításában.

A LEADER kezdeti szakaszában a Zala megyei települések az országos 14 akciócsoportból három alapítói voltak. A kezdeti lelkesedés, közös munka azonban mára alábbhagyott, mint ahogyan a bizalom is lecsökkent a LEADER-rel kapcsolatban (DobA Sz. 2009). A programmal szemben fellépő bizalmatlanságot a Zala megyei Csonkahegyhát polgármestere az önerő nehézkes előteremtése mellett a nehézkes ügyintézéssel és a sokszor érthetetlen kizáró feltételekkel magyarázza (21. idézet). Bár 
örül a fejlesztési lehetőségnek, de hangsúlyozza a fejlesztési források elérésének nehézségét, bürokratikus voltát a fertőhomoki polgármester is, ahol az interjú készítése előtt a LEADER keretein belül a környező településekkel való együttmüködésben kerékpárút kialakítása zajlott (22. idézet).

21. idézet: „Nagy lelkesedéssel ugrunk neki, mert 90\%-os támogatottság van, de ha jobban megnézzük, akkor nem felelünk meg a feltételeknek. Például a településlétszám miatt. (...) Faluközpont fejlesztésre is pályáztunk, de lassú az elbírálási folyamat. Amikor meg elbírálják [t.i. a pályázatot], akkor meg sokszor kapkodni kell." - Csonkahegyhát polgármestere

22. idézet: „Ma tele van az ország LEADER táblával, hogy milyen jó együtt dolgozni, de a mi esetünkben ez pénzügyileg komolytalan." - Fertőhomok polgármestere

A vizsgálatba vont falvak másik része vagy nem tud, vagy nem is akar együttes erővel forráshoz jutni. Előbbi esetre példa Romonya szennyvízberuházása. Bár Magyarsarlós, Nagykozár, Bogád és Romonya közös befektetést tervezett szennyvízberuházás kapcsán, az mégsem valósult meg (23. idézet), annak ellenére sem, hogy Romonya Magyarsarlós költségeinek egy jelentős hányadát átvállalta volna.

Utóbbira Gosztola citálható példaként, ahol a polgármester nem is akar a környező településekkel összefogva pályázni, a települések fejlődése szempontjából fontos fejlesztéseket illető eltérő gondolkodásmód miatt. Abban azonban az összefogni nem tudó, vagy nem akaró települések is egyetértenek, hogy az ő számukra is nagyon nehéz az önrészt előteremteni, valamint hogy a pályázati lehetőségek korlátozottak. Romonya polgármestere pedig azt a közeljövőt érintő súlyos problémát is megfogalmazta, mely szerint előnyösebb helyzetükböl adódóan a forrásokhoz való hozzájutás nehézkesebb feltételei rövidesen a település ellehetetlenedését is előidézhetik (24. idézet).

23. idézet: „A környező településeknek ehhez hozzá kellett volna járulni, de 2 település meggátolta ezt. A semmiért gátolták meg, ez szüklátókörüség. Így aztán nem jellemzö az összefogás. Kicsit magunkba fordulunk, mindenki megpróbálja a maga szemétdombját rendbe tenni." - Romonya polgármestere

24. idézet: „Előnyös településnek számítunk. A pályázati forrásokhoz nem jó feltételekkel jutunk, magasabb önrész kell. A hátrányos helyzetü települések ezt sokkal könnyebben megússzák. Most már úgy tünik, hogy az elönyös helyzet fogja az elszegényedést okozni. Sikeres településekröl beszélünk, de ott vagyunk a csőd szélén." - Romonya polgármestere

Szinte valamennyi polgármester hangsúlyos elemként értékeli a vizsgálatba vont falvak sikeressége szempontjából a helyi közösség aktivitását, a faluban 
megrendezésre kerülő rendezvényeket, és a lakossági szerveződéseket, melyek fontosságát a statisztikai adatelemzés és a lakossági kérdőívezés eredményei is igazolták. A helyi civil szervezetek jelentősége a kistelepülések életében a hazai és nemzetközi szakirodalomból ismert jelenség, Magyarországon a falusi iskolák fenntartására irányuló kezdeményezésekből vált közismertté (FORRAY R. K. 1995, Fickermann, D. - Weishaupt, H. - Zedler, P. 1998, Starr, K. - White, S. 2008).

A civil szervezetek mellett a nemzetiségeknek, és a hozzájuk kötődő hagyományőrzésnek is fontos szerepe van a települések életében. A nemzetiségeket főleg a németeket - általánosságban is a tevékenység, szorgalom, tenni akarás jellemzi (GÁSPÁR G. 1986, WINICZAI K. 2001), így nem véletlen, hogy a vizsgált falvak közül a Fertőhomokon müködő Horvát Kulturális Egyesület tagjai (25. idézet) és Dunaszentmiklós (6. kép - 8. sz. melléklet) német nemzetisége legaktívabbak a hagyományőrzés területén (26. idézet), de Apátistvánfalva Faluszépítő és Hagyományőrző Egyesülete is tevékeny (27. idézet, 28. idézet). Dozmaton az Együtt Dozmatért Egyesület szabadidős, sportprogramokat szervez. Minden télen megrendezésre kerül a közösségkovácsoló szándékú házaspárbaj, müködik helyi Caritas, vöröskereszt. Hegymagason Nyugdíjas Klub van, melynek tagjai a falu rendezvényein, mint szereplök is részt vesznek. Tivadaron a Jeles Napok a Beregben rendezvénysorozat igényel közösségi összefogást a falu lakói részéről, Romonyán fúvószenekari találkozó és sportnapok közösségkovácsoló erejűek. Testvérvárosi kapcsolata a legtöbb településnek van, de ezek a kapcsolatok általában névlegesek (29. idézet), bár több településvezető lát lehetőséget e kapcsolatok szorosabbra füzésében.

25. idézet: „(...) jó hangulatban telnek a rendezvények, szeretjük csinálni.”egyesületi tag (Fertöhomok)

26. idézet: „(...) összetartunk, ragaszkodunk a hagyományokhoz, sok helyre járunk fellépni.” - egyesületi tag (Dunaszentmiklós)

27. idézet: „(...) szemétszedés volt a faluban, sokan jöttek.” - egyesületi tag (Apátistvánfalva)

28. idézet: „A lakosok nagyon aktívak, sokat tesznek a faluért.” - Apátistvánfalva polgármestere

29. idézet: „Ezekben hatalmas lehetöség van, de ezeket siettetni nem lehet.” Hegymagas polgármestere

A települési vezetők véleménye megoszlik abban a tekintetben, hogy mi a jobb egy kistelepülésnek, ha vannak intézményei, vagy ha nincsenek. A polgármesterek egy része annak a híve, hogy fenn kell tartani minden erővel, akár egyedül is a már meglévő intézményeket, ők vannak kisebbségben. Így gondolkodik Csonkahegyhát 
önkormányzata, ami az utóbbi évek finanszírozási nehézségei ellenére is fenntartotta iskoláját, úgy hogy közben a kapott források nem elegendők a feladatok ellátására. Müködik óvoda, iskola, orvosi rendelő is a településen (3. kép - 8. sz. melléklet). Fertőhomokon házi segítségnyújtás működik helyben, szociális étkeztetés elérhető a faluban, melyet a kevés számú igénylő számára a település szintén egyedül old meg (30. idézet).

A vizsgálatba vont falvak másik - nagyobb része - a környező településekkel együttmüködve tudja elképzelni az intézmények fenntartását. Ez nem magyar sajátosság. Az Európai Unió más országaiból is számos példa citálható a falvak közti útfenntartás, szennyvíztisztítás, oktatás területén történő együttmüködésre (OROVA M. 2006). Így például Dozmaton nincs egyénileg fenntartott intézmény (31. idézet), kivétel nélkül társulásban oldják meg a feladataikat. Hegymagason könyvtár elérhető helyben, a diákok iskolába Szigligetre, vagy Tapolcára járnak. Tivadaron a gondozási központ, orvosi rendelö, nyugdíjas klub fenntarthatósága vált megkérdőjelezhetővé az elmúlt években, mivel ezek az intézmények milliós nagyságrendű deficitet termeltek. Ennek eredményeként be kellett zárni a klubot, és az azt ellátó konyhát is. Tivadar esetében is a társulás jelentett megoldást, jelenleg Kisar községből megoldott az étkeztetés. Szintén együttmüködés keretein belül, Kisarral közösen tartják fenn az iskolát, télen a falugondnoki busszal szállítják a gyerekeket iskolába.

A közlekedési kapcsolatok Dunaszentmiklóson, Fertőhomokon, Romonyán, Szántódon és Klárafalván a legjobbak. Ez utóbbi településen Szeged elérhetősége indokolja a magas tömegközlekedési járatszámot (32. idézet).

30. idézet: „Házi gondozás, ha ténylegesen komoly lenne, akkor nem tudnánk megoldani." - Fertőhomok polgármestere

31. idézet: „(..) nem kell törekedni arra, hogy mindenáron ragaszkodjunk az intézményeinkhez." - Dozmat polgármestere

32. idézet: „(...) sok járatra van szükség. Szegeden dolgoznak, Deszkre mennek szanatóriumba." - közlekedési szakember (Klárafalva)

Az 500 fö alatti kistelepülések jelentős részében, Vas megyében például $40 \%$ ában található valamilyen épített látnivaló (CSERTA O. - NOVÁK Z. - VÖRÖS L. 2004). A disszertációban vizsgált falvak két részre oszthatók turisztikai adottságaikat tekintve, azokra, amelyek rendelkeznek természeti vagy épített vonzerővel, és azokra, amelyek nem. Egy sajátos csoportjuk pedig speciális vonzerővel rendelkezik, mely vonzerőt a városközelség jelenti számukra. 
A kutatott aprófalvak megyéi közül több esetében is fellelhetök falusi turizmussal foglalkozó tanulmányok (Csordás L. - SzABó G. 1993, CsAPó T. - SzABó G. 1997, HANUSZ Á. 2002), melyek mindegyike fontos kitörési lehetőségként kezeli a falusi turizmust a kistelepülések életében, ugyanakkor reálisan nem várható az el, hogy valamennyi aprófalu megéljen a turizmus nyújtotta lehetőségekből (KoVÁcs T. 2004).

Ez utóbbi megállapítás azzal is alátámasztható, hogy az idegenforgalom mutatócsoport magas fejlettségi értéke már a statisztikai vizsgálatok kapcsán sem jelentett automatikusan a települést jellemző magas összfejlettségi értéket. A disszertációban ismertetett kutatás azt is bizonyította, hogy míg egyes falvak előnyt kovácsolnak a turisztikai adottságaikból és az erre épülő falusi turizmussal a lakosok közül többen foglalkoznak, addig a települések másik része csak kényszerből fogad vendégeket otthonában, vagy lakóingatlanában, egy harmadik csoport pedig nem aknázza ki a turizmus adta lehetőségeket.

A Tisza-partján elhelyezkedő beregi Tivadaron prioritásként kezelik a falusi turizmust a lakosok (33. idézet). Már az 1960-as, 1970-es években is lehetett itt bérelni nyaralókat (PRISTYÁK E. 2004). Az igazi nagyüzem csak a rendszerváltozás után következett, a tivadari üdülőterületre (14. kép - 8. sz. melléklet) és szabad strandra alapozva kezdtek el egyre többen falusi vendéglátással foglalkozni. A falusi turizmus kiépítését a polgármester kezdte, azóta 10 család foglalkozik vele, a lakosok szívesen tevékenykednek a falusi turizmusban. Szintén elsődleges fontosságú a turizmus Szántódon (13. kép - 8. sz. melléklet), ahol a hazai utazóközönség mellett a külföldi turistákra is számítanak (34. idézet), ezért nagy hangsúlyt fektetnek a nyaralók, üdülőházak rendben tartására.

Zala megyében, főként Szentgyörgyvölgy környékén meglehetősen magas számú épített örökség és védett természeti érték található (GYURICZA L. 1998). A Zala megyei Csonkahegyhát viszont a második típust képviseli. Itt 1-2 falusi turizmussal foglalkozó család él. Ök más lehetőség hiánya miatt választják a turizmusnak ezt a formáját és többen összefonják ezt a tevékenységet mezőgazdasági termeléssel.

A harmadik csoportba azok a települések tartoznak, akik gondolkoznak rajta, de nem aknázzák ki a turisztikai adottság nyújtotta lehetőségeket, vagy azért mert nincs rá mód, vagy azért, mert nem térülne meg a beruházás. Előbbire példa Romonya, ahol termálvíz hasznosításra lenne lehetőség, több törekvés is volt beruházás kialakítására, de befektető és pénzhiány miatt meghiúsult a termálvíz hasznosítása (35. idézet). Utóbbira példa Dozmat és Hegymagas. Ezekben a falvakban a meglévő attrakció nem generál 
akkora turizmust, ami számottevő bevételi forrást jelentene a falvak lakosai számára, így nem ruháznak be falusi szállásadásba. Dozmaton, a völgyben lévő forrás, a templom - bár a terület felújításra került - csupán néhány kirándulócsoportot, gyalogtúrára érkezőt vonz (36. idézet) és a Balaton-Felvidéki Nemzeti Park területén fekvő Hegymagas sem profitál sokat a faluban lévő Lengyel-kápolnából. Ez utóbbi falu hiába fekszik borvidéken, a borászat marketing hiányában szintén nem jelent jelentős turisztikai potenciált a település számára (37. idézet).

33. idézet: „Nyáron telt házzal üzemelnek a vendégházak. Télen nem olyan sok a vendég." - óvodapedagógus (Tivadar)

34. idézet: „(...) ide külföldi, nagypénzü turisták is jönnek.” - Szántód polgármestere

35. idézet: „(...) van itt egy meleg vizes fúrás, erre lehetne építeni.” - Romonya polgármestere

36. idézet: „(...) a templom a dombon, a forrás a völgyben magánterület volt, dzsumbujos, megvettük, felújítjuk. Nevezetesség az Árpád kori templom, mint épített örökség. De a regélt történelem és az irott történelem is jelen van.” Dozmat polgármestere

37. idézet: „Csodálatos borok vannak. Badacsonyi borvidékként szerepel. Megjelenik a címkéken, de nem Szent-György hegyi borként van leírva.” Hegymagas polgármestere

Említést kell tenni a vizsgált falvak turisztikai értékei mellett egy speciális vonzerőről is, melyet a városközelség jelent. Így Romonya számára a természeti környezet szépsége, a település fekvése mellett a Pécs közeli helyzete is vonzó. Az önkormányzat által kialakított házhelyeknek köszönhetően a lakosságszám az elmúlt években növekedett, a természeti értékeknek és Pécs 4-5 km-es közelségének a hatására többen vállalták a lakóhelyváltást. Ez a migrációs folyamat kettős hozadékkal bír Romonya életében, egyrészt az őslakos romonyai polgárok vagyona is felértékelődött (38. idézet). Másrészt a kitelepedő, gyakran magas státuszú népesség elősegítheti a település sikerességét, mint azt kutatások igazolták (IzSÁK É. 1999). Az újonnan épített lakások a modern kor minden igényét kielégítik (39. idézet), csakúgy, mint Dozmaton (40. idézet).

Azonban nem minden vizsgálatba vont falu tud élni a beköltözők nyújtotta előnyökkel. Bár Csonkahegyhátat nem soroltam a szuburbán települések közé a vizsgálatba vont falvak kiválasztása során, mégis érdemes a városközelség kapcsán említést tenni róla, mivel Zalaegerszegtől mindössze $15 \mathrm{~km}$-re helyezkedik el, és a földrajzi adottságai is jók. Ami a falu számára nehézséget jelent a beköltözők 
idevonzásában, az a házhelyek relatív drágasága. Az önkormányzatnak nincsenek ugyanis olyan ingatlanjai, amiből házhelyeket lehetne kialakítani. A helyi földtulajdonok magánkézben vannak, azok megvásárlására az önkormányzatnak anyagi források hiánya miatt nincs lehetősége, így Csonkahegyháton az elmúlt 2 évben mindössze 3 új családi ház épült Zalaegerszeg közelsége ellenére is (41. idézet).

38. idézet: „Lakóparkot csináltunk, utakat építettünk, víz, stb. infrastruktúra fejlödött." - Romonya polgármestere

39. idézet: „A lakópark lakásai minden komforttal felszereltek. A tulajdonosoknak minden kényelme biztositott." - ingatlanfejlesztö (Romonya)

40. idézet: „(...) folyamatos az építkezés, az eddig elkészült lakásokkal kapcsolatban nem érkezett panasz." - ingatlanfejlesztö (Dozmat)

41. idézet: „Inkább az a fontos, hogy egy házhely mennyibe kerül. (...) az lenne jó, ha nem kellene adnom 1-2 millió forintot, hanem csak egy jelképes összeget. Ez hátrány itt." - Csonkahegyhát polgármestere

Összegezve tehát a polgármesterek és a helyi elit tagjai a korábban ismertetett, a települések fejlődése szempontjából sikerességi tényezőként megnevezett lakossági és polgármesteri aktivitás, konfliktusmentesség és megfelelő számú munkaalkalom mellett a pályázati hajlandóságot, a megfelelő intézményi és ellátottsági helyzetet, a nemzetiségi jelenlétet és az arra alkalmas településeken a turisztikai potenciálban rejlő lehetőségek kiaknázását is megfogalmazták a fejlődést segítő tényezők között.

Amennyiben az aprófalvak polgármestereit - a statisztikai elemzésekhez kapcsolódóan - a környező települések közti helyzetről is kérdezem, az elégedett, a büszke, de elégedetlen és a külön utakat járó településeket különíthetem el.

Tivadarban a falusi turizmus adta lehetőségek kiaknázása az elégedettség oka. Nem véletlen, hogy a Vásárosnamény környéki kistelepüléseken így a kistérség periférikus helyzetü településeihez viszonyítva magasabbak a jövedelmi mutatók értékei és alacsonyabbak a munkanélküliségi adatok, mint az korábbi kutatások kimutatták (KISS J. P. - LÖCSEI H. 2005). A beregi térség elszenvedte a 2001-es tiszai árvizet, talpra állt, Tarpán, Tákoson, Csarodán, Vámosatyán, Tivadaron és a beregi térség egyéb településein néhány év alatt 60 milliárdos beruházás valósult meg (42. idézet), melynek egy része a falusi turizmushoz köthető.

A fertőhomoki polgármester is büszke az általa irányított falura, és arról beszél, hogy sok település vergődik forráshiánytól, de Fertőhomok és térsége nem tarozik közéjük. Csonkahegyhát polgármestere is jónak értékeli a falu helyzetét a környező települések között, de a környező falvakat is erősnek tarja (43. idézet). Ez a polgármesteri vélemény egybecseng a lakossági kérdőívek környező településekre 
vonatkozó kérdésének és a vizsgált aprófalvak környékbeli falvaira elvégzett statisztikai vizsgálatának eredményeivel is.

42. idézet: „Tivadart - lehet hogy elfogult vagyok - a Felsö-Tisza egyik legszebb településének tarom." - Tivadar polgármestere

43. idézet: „A környezetünk értékel minket. Egy térség akkor erös, ha sok erös települése van.” - Fertőhomok polgármestere

A büszkék, de elégedetlenek táborából tipikus példa Romonya (44. idézet) és Dozmat (45. idézet). Romonyán és Dozmaton is élenjárnak a településvezetők a közösségépítésben. A romonyai polgármester e mellett az infrastruktúra kiépítésére, a gondozott településképre is büszke, de ugyanakkor azt is látja, hogy Bogád és Nagykozár is fejlődésnek indult, és ez a fejlődési dinamizmus erőteljesebb, mint az interjú időpontjában a romonyai fejlődés. A dozmati polgármester a szuburbanizáció nyújtotta lehetőségekkel elégedett, a meglévő potenciálok kiaknázásában viszont lát hiányosságokat.

44. idézet: „(...) mindig elégedetlen vagyok. Sokkal többet is el lehetett volna érni." - Romonya polgármestere

45. idézet: „A többi falu is elismeri azt, hogy igyekszünk.” - Dozmat polgármestere

A különmozgók közül Fertőhomok lakosságának a részéről megvan az igény a környező települések felé nyitottabbá válásra, itt a polgármester mutat zárkózottságot (46. idézet). A gosztolai út is sajátos, melynek alapját a polgármester és a falu viszonya adja. Itt nem olyan faluról beszélhetünk, amelynek polgármestere van, hanem olyan polgármesterről, aki faluval rendelkezik. A polgármester Gosztolát sajátjaként kezeli, ahol a településkép megfelelő voltáról nem a tulajdonosok, hanem az önkormányzat alkalmazottai gondoskodnak, ahol a lakosságtól elvárás a dohányfüst mentes élet, ahol rendelet születik a közösség ellenes tevékenységekről. A polgármester nagyon igényes a környezetével szemben, éles kontraszt figyelhető meg a környező kistelepülések Lovászi, Resznek, a Hetés - vályogházai és Gosztola, a polgármesteri hivatal alkalmazottai által karbantartott utcái, udvarai között (47. idézet).

46. idézet: „Az, hogy íródik 2-3 cikk havonta, az a településvezetöt szolgálja nem a települést. Nekem meg nincsenek ilyen ambícióim." - Fertöhomok

47. idézet: „Nem a tulajdonos tartja karban az utcákat, kerteket, hanem mi.” Gosztola polgármestere 
A jövőt illetően a megkérdezett polgármesterek egy része bizakodó, gyakran annak ellenére is, hogy a helyi fiatalok a föiskola, egyetem elvégzése után elköltöznek a településről. Bár a fent említett értelmiségi migráció a beregi Tivadart is érinti, a polgármester itt a leginkább bizakodó. A település vezetője az elindított fejlesztések megvalósításra jó esélyt lát, a felsőfokú végzettségüek elvándorlása ellenére a falu lakossága nem fogy. A Baranya megyei Romonya polgármestere a szennyvízberuházás megvalósulására lát jó esélyt, további beruházásokat sürget (48. idézet), a település életben maradását a lakosságszám kismértékü növekedése által biztosítottnak látja. Bár a házhelyek iránt a felmérés idején megcsappant a kereslet, néhány telek értékesítésére minden évben lehetöség van.

48. idézet: „Lesz egy strand egyszer Romonyán.” - Romonya polgármestere

A települések polgármestereinek másik része szkeptikus a jövőt illetően. A csonkahegyháti polgármesternek az ügyintézés, pályázat előkészítés, a napi megélhetés terén tapasztalt aggályairól alkotott véleményét a pályázati tevékenységgel kapcsolatban a korábbiakban ismertettem. Mivel a település saját maga írja pályázatait - mert nem tud pályázatíró céget megfizetni -, valamint a települési önerő is csekély (49. idézet), így a településvezető nem lát lehetőséget fejlődésre. A források elérése még a statisztikailag fejlett, jó lakossági megítélésü Fertőhomokon is nehézségekbe ütközik, így a fejlesztések elérhetetlennek tünnek (50. idézet), az elhagyott ingatlanok felújítására, értékesítésére, az öregedés kapcsán felmerülö problémák megoldására, egészségesebb településkép kialakítására nehezen alakítható ki a lehetőség.

49. idézet: „A kistelepülések halálra vannak itélve, mert nem tudnak öneröböl elöre lépni." - Csonkahegyhát polgármestere

50. idézet: „(...) nem nagyon döngették itt az uniós források a kapukat.” Fertőhomok polgármestere

$\mathrm{Az}$ interjúkban rögzített polgármesteri vélemények szerint az aprófalvak sikerességének tényezői tehát három nagyobb tényezőcsoportba, az emberi tényezők, ellátottságbeli tényezők, és a település müködésének zavartalan biztosítottságának tényezői közé sorolhatók. 
A sikeresség eléréséhez az emberi tényezők között legfontosabb a falu lakóinak helyben tartása, új lakosok letelepítése (51. idézet), a település lakói közti összetartás. A vizsgált falvakon belüli közösségépítés (mely a nemzetiségi településeken általában jól müködik), a lakosság közti jó viszony kialakítása, a település lakói számára minél jobb életminőség biztosítása, a konfliktusmentesség és a megfelelő számú munkaalkalom biztosítása szinte valamennyi megkérdezettnél hangsúlyos elemként jelentkezik a falu fejlődése szempontjából. Legerőteljesebben a Veszprém megyei Hegymagason (52. idézet) ${ }^{24}$ figyelhető meg az összefogás iránti igény. A településvezetők abban is egyetértenek, hogy a közösségi siker fontos, de nem érhető el a település lakosainak egyéni sikere nélkül (53. idézet).

Az ellátottságbeli tényezők közül a polgármesterek véleménye szerint az infrastrukturális és intézményi ellátottság elengedhetetlen a sikerhez, mint ahogy a településben rejlő potenciál (turisztikai, emberi) is. A megkérdezettek szerint szükséges az egészséges ivóvíz, a megfelelő minőségű utak, villamos áram-, csatorna- és földgázvezetékek megléte. A vizsgálatba vont falvak közül Tivadar indult a legnagyobb hátránnyal a vonalas infrastruktúra tekintetében (54. idézet), mely hátrányt a település napjainkra ledolgozta. Az alapfokú infrastruktúra és ellátottság szükségességét a legkevésbé fejlett Fony polgármestere, jegyzője, és munkaszervezeti vezetője is hangsúlyozta (55. idézet).

51. idézet: „(...) megmenteni egy falut a haláltól.” - Gosztola polgármestere 52. idézet: „A közösségi sikerhez szükséges tehát az, hogy a település polgárai egyenként is sikeresek legyenek, hogy mindenki kiálljon a saját véleménye mellett." - Hegymagas polgármestere

53. idézet: „Ha jó szándék mentén tudunk egymáshoz, közelíteni, akkor lehetünk sikeresek." - Fertöhomok polgármestere

54. idézet: „2002-ben nem volt olyan számítógép, amelyen egy levelet meg tudtam volna írni." - Tivadar polgármestere

55. idézet: „1996-2002-ig minden évben lett intézmény, konyha, óvoda, iskola, tájház, orvosi rendelö." - Fony polgármestere

Fontos tényező a település sikeressége szempontjából annak zavartalan müködése. Ehhez több dolog szükséges. Egyrészt a települési intézményi és egyéb infrastruktúra szinten tartása, vagy fejlesztése, másrészt a települések közti összefogás kialakítása, illetve a magas pályázati hajlandóság - akár egyedül, akár más településekkel összefogva. Csonkahegyhát polgármestere sikerként értékeli, hogy az előző évekhez

${ }^{24}$ Nem csupán Hegymagas polgármestere hangsúlyozza az összefogás fontosságát, a megye számos kistelepülésének polgármestere is hasonlóan vélekedik erről a kérdéskörről (BERTA GY. 2005). 
képest az intézmények, ellátottság terén visszalépésre nem került sor (56. idézet), Dozmat polgármestere pedig sikerként értékeli, hogy a település nem adósodott el, működőképes maradt (57. idézet). Tivadarban a falu esővíz elvezető csatornáinak felújítása, a polgármesteri hivatal felújításának, a park és a harangláb rendbetételének megvalósulása került sikerességi tényezőként említésre. A települések közti összefogást Hegymagas (58. idézet) polgármestere hangsúlyozta leginkább. A polgármesterek elmondták, hogy nem csak a fejlődéshez, de már az életben maradáshoz is sok esetben szükséges a települések egymást segítő magatartása.

56. idézet: „Folyamatos küszködés volt az elmúlt években az életben tartása [ti. az iskolának]. Ami az elmúlt időszakban megvolt, ahhoz képest visszalépésre nem kerül sor." - Csonkahegyhát polgármestere

57. idézet: „Mindezt meg tudják úgy tenni, hogy müködőképesek maradtak. És ez a mai világban siker." - Dozmat polgármestere

58. idézet: „Az életben tartása csak az lehet [t.i. az aprófalvaknak], hogy összefognak ezek a kistelepülések, és egymáson segítenek.” - Hegymagas polgármestere

Összegezve a polgármesteri és helyi elit tagjaival folytatott interjúk eredményeit a statisztikai úton és lakossági kérdőívezés által lehatárolható sikerességi tényezők mellett olyan új elemek is lehatárolhatók a fejlődés elemeiként, mint a települési rendezvények közösségkovácsoló ereje, a pályázati hajlandóság, konfliktusmentesség és a falu zavartalan müködése. A fejlődést segíti továbbá, ha a polgármester több cikluson keresztuil a helyén marad. Az interjúk megerősítették a lakossági aktivitás, nemzetiségi jelenlét, környezet rendben tartása, együttmüködés, turisztikai potenciál kiaknázása, valamint a település szuburbán volta tényezők fontosságát is a sikeres falu kialakítása érdekében.

\subsection{A vizsgálatba vont falvak honlapjainak fényképein található sikerességi tényezők}

Amellett, hogy a lakosok és a helyi elit tagjai mit mondanak el a sikerességgel kapcsolatban egy kérdöíves felmérés, vagy interjú során, sokat mutat az is, hogy a település vezetése a községi honlapokra feltöltött fényképek által mit kommunikál a faluról. Márcsak azért is, mert a községi honlapokra feltöltött fényképeknek marketingértéke van, mely statisztikai úton nehezen kutatható, a puha vizsgálatok közül lakossági kérdőívezéssel is csak nehezen mérhető. A doktori disszertáció e részében így 
röviden ismertetem a sikerességi tényezők körét szintén gyarapító, a geográfiai kutatásokban kevésbé használt kutatási módszer, a fényképes tartalomelemzés eredményeit is.

A fotódokumentáción ez a módszer azért alkalmazható, mert rögzített kommunikáción végezhető kutatási módszerről van szó (KRIPPENDORF, K. 1995). Első módszertani felhasználására sajtóelemzésekben került sor. A tömegkommunikáció elterjedésével elsőként a rádióban, televízióban elhangzott szövegek elemzésére nyílt lehetőség.

A szöveges tartalom mellett azonban a képek tartalomelemzése is lehetséges, akár olyan sajátos térfelhasználási formát tanulmányozva, mint hogy az emberek milyen távolságokat tartanak beszélgetés közben (HALL, E. T. 1987), vagy, hogy milyen objektumok hány alkalommal szerepelnek a képeken (ANTAL L. 1976), és azok milyen információt hordoznak a kutató számára (FLUSSER, V. 1990, KUNT, E. 2003, SzTOMPKA, P. 2009).

Ma egyre több társtudományban nyer újra teret a képi anyagok felhasználása a kutatások során, így véleményem szerint a disszertáció kutatási módszerei között is van létjogosultsága. A disszertáció készítése során a vizsgált aprófalvakba ellátogatva törekedtem arra, hogy - kistelepülések révén - a falvak valamennyi utcájáról készüljön fotódokumentáció. Előzetes terveim szerint a fotódokumentáció elemzést a terepen rögzített fotókon és a községek honlapjainak képi anyagán is elvégeztem volna. A terepen készített fényképanyag elemzése azonban - annak ellenére, hogy a falvakban található valamennyi objektum megörökítésre került - véleményem szerint felvetheti a kutatói szubjektivitás problémáját a módszertanban. A terepen készült fényképeken található objektumokról azonban készült egy összefoglaló ábra, melyben a többféle módszerrel lehatárolt sikerességi tényezők néhány manifesztációja is megtalálható (18. ábra - 6. sz. melléklet). A terepen rögzített fényképek tartalomelemzésére tehát nem került sor, viszont a falvakban tapasztaltakat igyekszem a honlapok tartalomelemzésével összevetni, a terepi fényképek továbbá a kutatás ábraanyagául is szolgálnak.

A módszer alkalmazása annyiban állt, hogy a szakirodalom áttanulmányozását követően a 16 vizsgálatba vont falu sikerességi faktorait illetően felállítottam egy kategóriarendszert (intézmények, kereskedelmi egységek, szolgáltatások, idegenforgalmi adottság, gazdasághoz, közlekedéshez, közösséghez kapcsolódó objektumok stb.) melynek elemeit kerestem az aprófalvak községi honlapjainak képi 
anyagában. Törekedtem arra is, hogy a községi honlapokon megtalálható fényképeken szereplö információkat a terepbejárás alkalmával látottakkal is összevessem.

Arra kerestem a választ, hogy vajon a falu vezetése mit kommunikál magáról a képeken keresztül a világhálón (BABBIE, E. 2003), valamint, hogy a korábbi kvantitatív és kvalitatív elemzések által lehatárolt sikerességi tényezők közül melyek jelennek meg a községi honlapokon (10. táblázat).

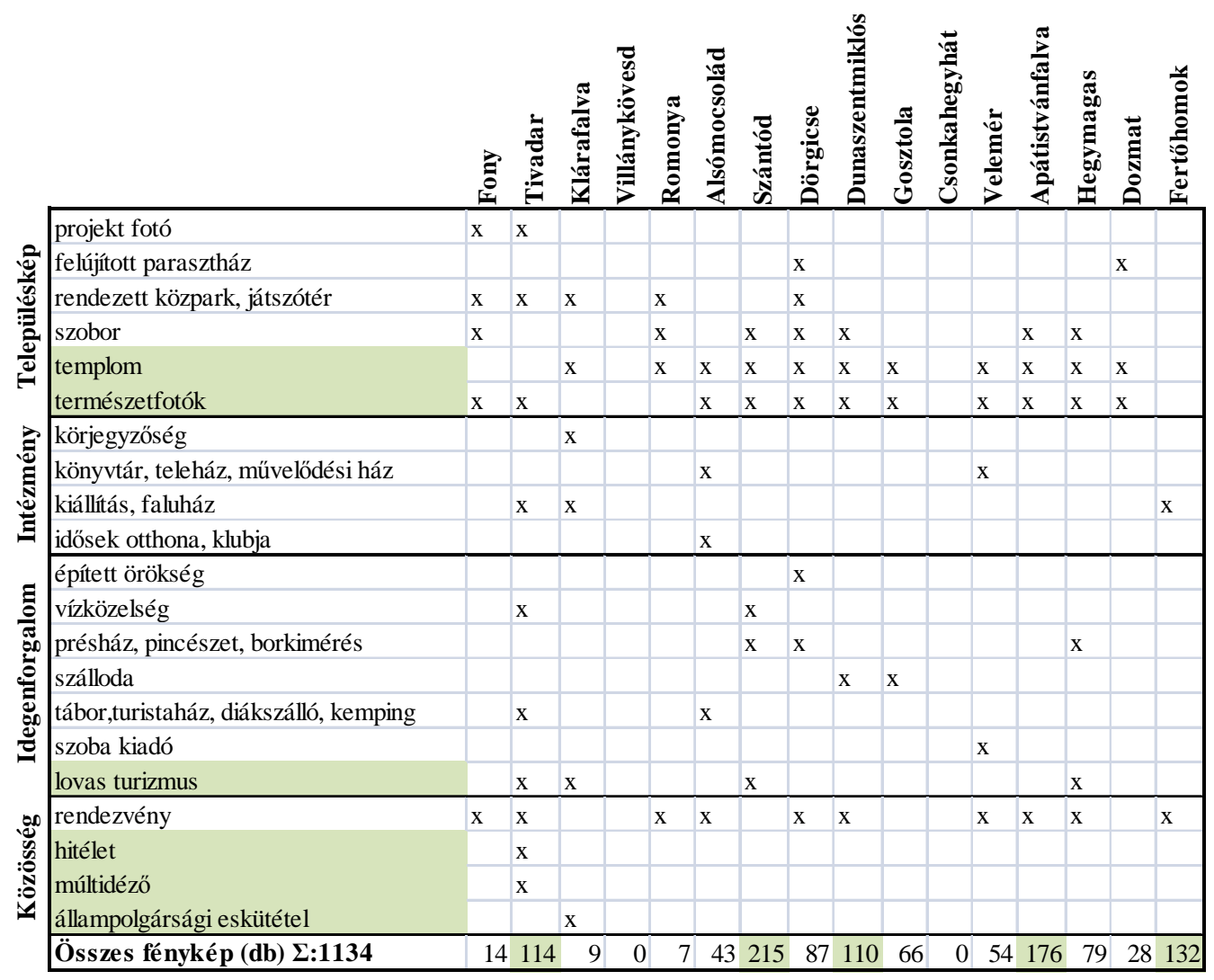

10. táblázat. A vizsgálatba vont falvakban működő honlapok képi anyagának sajátosságai a sikeresség szemszögéböl

(Forrás: saját szerkesztés)

Villánykövesd és Csonkahegyhát községek kivételével (ennek a két falunak a vizsgálat idején nem volt honlapja) valamennyi vizsgálatba vont falu honlapjának képi anyagát áttekintetettem (1134 felvétel), és a fényképeken szereplő objektumokat kódoltam a korábbi kategóriarendszernek megfelelően. Az adatrögzítés ilyen felhasználása mutatja, hogy a disszertációban a fényképezésnek, mint társadalomtudományi kutatási formának a szisztematikus adatrögzítésre való használhatóságát tekintve Wagner-rel értek egyet (WAGNER, J. 1979), azaz a terepi munka során készített fényképeket döntően kvantitatív módon, a sikerességi tényezőket keresve elemeztem. 
A községi honlapok fotódokumentáció elemzése alapján elmondható, hogy a településképhez kötődő objektumokat legnagyobb számban Dunaszentmiklóson és Alsómocsoládon valamint Tivadaron és Dörgicsén találunk.

A rendezett utcakép, parkosítás, információs táblák kihelyezése a fent említett településekben a terepbejárás alkalmával is megfigyelhető volt. A községi honlapokra feltöltött fényképeken ehhez a kategóriához kapcsolódóan a rendezett közparkokról, játszóterekről és szobrokról találtam a legtöbb fotót.

Nem szokványos aprófalut jellemző településképet mutatnak Dozmat és Romonya terepen lefotózott lakóparkjai (4. kép, 12. kép - 8. sz. melléklet), bár ahogyan az interjúkban felvett adatokból kiderült, ezeket a lakóparkokat igyekeztek építészeti stílusukban a falu többi lakóházához igazítani, a községek honlapjain viszont nem találhatók az építkezésekről fotók [4],[19].

A terepbejáráson kiderült, hogy Dunaszentmiklós településképét az utóbbi években szállodaépítés formálta, melyhez kötődve kamerás megfigyelőrendszer került kiépítésre az üdülőfalu területén. Az újonnan épült szállodáról a község honlapján is több fénykép elérhető [5]. Szinte minden község honlapján megtalálható volt a feltöltött fényképek között a község temploma, valamint a feltöltött fényképek 34\%-át tették ki (1134-ből $384 \mathrm{db}$ ) az aprófalvak honlapjain megtalálható természetfotók. Ennek a faktornak a megléte tehát nem csak a statisztikai felmérésben jelentkezett fejlesztő hatásúnak, hanem a lakossági véleményekben is hangsúlyos elemként jelentkezett, valamint a községi honlapokon a falvakról leginkább kommunikált elemek között szerepelt.

Az ellátottság kategória legtöbb eleme a terepbejárás során Fonyban került lefotózásra, de több ilyen tényező van Fertőhomokon és Csonkahegyháton is. Mind a statisztikai adatelemzés, mind a lakossági kérdőívezés és a helyi elit tagjaibal folytatott interjúk is felhívták a figyelmet a fejlődéshez elengedhetetlen ellátottsági elemek meglétére.

A terepbejárás alkalmával megfigyelt ellátottsági elemek közül a postai szolgálat fennmaradása a dél-nyugati országrészben megfigyelhető, az osztrák és szlovén határ mentén orvosi, fogorvosi rendelö is található. A kiírások alapján valószínüsíthető, hogy ezeket a szolgáltatásokat elsősorban külföldi lakosok veszik igénybe. Az északnyugati országrészben (Fertőhomok, Dozmat) a kis lélekszám ellenére szintén döntően az ide látogató külföldiekre alapozva gyógyszertár is üzemel. Annak ellenére, hogy a lakossági válaszoknál és az interjúknál érzékelhető volt az ellátottságbeli helyzet fontossága a település lakosai számára, a vizsgált falvak honlapjainak fényképein az ellátottsághoz 
kapcsolódó tényezők nem lelhetők fel. Korábbi kutatások igazolták annak tényét, hogy az ellátottsági elemek meglétét a falvak képi formában szinte egyáltalán nem kommunikálják (SzTOMPKA, P. 2009), a disszertáció fotódokumentáció elemzése ezt a legkisebb lélekszámú falvak esetében is megerősítette.

A fotódokumentáció tartalomelemzése megerősítette továbbá a szolgáltatásokkal való ellátottságot, mint a sikeresség egyik faktorát, leginkább Fertőhomok, Csonkahegyhát és a Balaton közeli Szántód és Dörgicse esetében. A szórakozási lehetőségek, presszók és vendéglők a turisztikai szempontból kiemelkedő Szántódon és Tivadaron vannak jelen nagy számban, a terepbejárás során ezek közül a legkülönbözőbb típusúakat rögzítettem.

Az üzletek specializációja leginkább Velemérre [23] és Csonkahegyhátra jellemző, a legfejlettebb vizsgált aprófalvak közül Szántód és Fertőhomok pedig az üzletek mellett a szolgáltatások területén is specializálódott. A terepen tapasztaltakkal ellentétben azonban a községi honlapokon a szolgáltatások jelenléte képi formában az ellátottsági tényezőkhöz hasonlóan nem jelenik meg. Írásos formában a szórakozási lehetőségekre elsősorban Szántód és Tivadar esetében viszont több utalás is található, ezek ismertetése azonban nem része a dolgozatnak, mivel az egy újabb típusú tartalomelemzés elvégzését is megkövetelné.

A korábbi vizsgálatok során a gazdasági szerepkör megléte nem jelentkezett sikerességi tényezőként az aprófalvak esetében. Ez a faktor a statisztikai vizsgálatban sem volt az összfejlettség szempontjából meghatarozó erejü. Továbbá a megkérdezett lakosok, és a helyi elit tagjai sem számoltak be gazdasági beruházás szükségességéről.

Annak ellenére, hogy a vizsgálatba vont falvak között szerepeltek olyanok, amelyek erős gazdasági potenciállal rendelkeznek - pl. Alsómocsolád - a honlapok képi anyagában sem volt fellelhető ilyen jellegü felvétel [1].

Bár a községi honlapokon nem találhatók a szolgáltatásokhoz, ellátottsághoz, gazdasági szerepkörhöz köthető fényképek, a terepbejáráson tapasztaltak közül egy, a gazdasági kategóriába kódolt objektumról még érdemes említést tenni. A szelektív hulladékgyüjtő konténer, vagyis a környezetvédelmi faktor a teljes faluállományon belül is statisztikailag legfejlettebb első 10\%-ba került Szántódon, Dunaszentmiklóson, Fertőhomokon és Gosztolán is jelen van [8]. Vagyis a legfejlettebb vizsgálatba vont aprófalvak valószínűsíthetően a környezet védelmére is hangsúlyt fektetnek.

A közlekedési feltételekről - mint ahogyan az ellátottságról és a gazdasági adottságokról - a községi honlapokra nem kerültek fel fényképek. 
Közlekedésfejlesztéshez köthető objektumok a terepbejárás során számos faluban megtalálhatók voltak, Szántód, Fertőhomok és Tivadar esetében részben a turizmus lehetőségeihez kapcsolódva ennek keretein belül valósult meg a bicikliút. Sürü buszmenetrendet jeleztek a tömegközlekedési eszközök megállóinak táblái a közeli nagyvárossal szerves kapcsolatban álló aprófalvakban (pl. Klárafalva), vagy a körjegyzőségi központ településeken (pl. Fertőhomok és Csonkahegyhát).

A turisztikai adottságok fontosságára az előzőleg ismertetett módszerek közül valamennyi felhívta a figyelmet. A terepbejárás során a turizmushoz kapcsolódó számos elem megtalálható volt, leginkább a Balaton környéki településeken (Szántód, Dörgicse, Hegymagas), Fertőhomokon és Villánykövesden.

A turizmushoz, épített és természeti örökséghez kapcsolódó objetumok egyébként is meghatározók a terepi fényképeken (KunT, E. 2003). Tivadaron, Veleméren, Csonkahegyháton és Fertőhomokon a táborok, turistaházak, kempingek, diákszállók kialakításával a kisebb pénzü turistákra, diákcsoportokra is gondolt a településvezetés illetve a lakosság. Nem meglepő az, hogy a települési honlapokon megtalálható fényképeken is ez volt az a kategória, amely a legtöbb feltöltött fényképet foglalta magába [20], [3]. A honlapok képi anyagának 37\%-a (1134-ből 420 db fénykép) valamilyen turisztikai adottsághoz kapcsolódott.

Még azoknak a falvaknak a honlapján is nagyszámban megtalálhatók voltak a turizmushoz köthető fényképek, amelyek esetében sem a statisztikai adatelemzés, sem a lakossági vélemények, sem a helyi elit nem tulajdonított fontos szerepet a turisztikai adottságoknak. Az épített és természeti örökségek, a szálláslehetőségek fotói mellett Tivadar, Klárafalva, Szántód és Hegymagas esetében a korábbi vizsgálatok során nem említett lovas turizmus lehetőségei is több fényképen megtalálhatók voltak [22], [11], [20], [9].

A korábbi vizsgálatokban sikerességi tényezőként jelentkező közösségi értékek közül a terepbejárás során is megfigyelhető volt néhány. Különböző rendezvényekről szóló plakátok döntően a nyugati országrész településein és a nemzetiségi településeken szerepeltek a hirdetőtáblákon. A községi honlapokon az ehhez a témakörhöz tartozó, vagyis a rendezvényeket ábrázoló fényképek az összes fotó 28\%-át adták (1134-ből 318 db-ot).

A rendezvényekről készült fotók szinte mindegyik vizsgálatba vont aprófalu honlapján megtaláhatók, legnagyobb számban Apátistvánfalván és Fertőhomokon [2], [6]. A községek honlapjainak fényképes tartalomelemzése két falu, Klárafalva és 
Tivadar esetében sajátos adatokkal gazdagította a kutatást. Klárafalván az állampolgári eskütételről találtunk nagyszámú fényképet, Tivadaron pedig a hitélet és a múltidéző fényképek adtak sajátos tartalmat a községi honlapoknak. A legtöbb honlapra feltöltött közösségi értékeket bemutató fénykép a turisztikai adottságokkal rendelkező aprófalvakban és a nemzetiségi településeken volt megtalálható.

Összegezve a fotódokumentáció elemzés megerősített azt, hogy a vizsgálatba vont falvak lakosai számára fontos a rendezett településkép és környezet. A legfejlettebb falvakban megjelent a környezettudatosság hangsúlyossága (a szelektív hulladékgyüjtés által), valamint fejlődést segítő elemként jelentkezett a korábban már többször megnevezett turisztikai adottság megléte és a közösségi aktivitás. A szolgáltatásokhoz, ellátottsághoz, gazdasághoz köthető fejlettségi faktorok meglétét (melyek egyébként a statisztikai elemzésekben, kérdőíves felmérésben és az interjúkban hangsúlyos sikerességi elemként jelentkeztek) a községi honlapok képi anyaga nem kommunikálta. Ennek oka valószínüsíthetően a honlapok célközönségében keresendő. 


\section{AZ APRÓFALVAK KVANTITATÍV ÉS KVALITATÍV MÓDSZEREKKEL LEHATÁROLT SIKERESSÉGI TÉNYEZÖI, A SIKERES APRÓFALU MODELLJE}

\subsection{Dinamaikus aprófalvakat jellemző tényezők, a falvak fajlődési útjai}

Kutatásom során a hazai aprófalvak sikeresség fogalomkört alkalmazó szakirodalmának áttekintése alapján sikerességi tényezőket határoltam le, melyek állandóságát 16 aprófaluban statisztikai adatelemzéssel, terepi munkával kutattam, illetve csoportosítottam és összevetettem egymással a különböző értékek mentén mérhető fejlődést, sikerességet eredményező faktorokat. A szakirodalom alapján a település szuburbán jellege, határmenti fekvése, nemzetiségi lakossága, turisztikai potenciálja, alapfokú intézményi és infrastrukturális ellátottsága és jó közlekedési helyzete voltak azok a tényezők, amelyeket több kutató is említett a fejlődés szükséges feltételeiként. Több szakirodalomban is fellelhető volt a település dezurbán volta, az ipari és a mezőgazdasági funkció megléte, mint sikerességi tényező.

A szakirodalmi áttekintés sikerességi tényezői közül az aprófalvak statisztikai vizsgálata megerősítette a magas nemzetiségi arányt, a település szuburbán helyzetét, a jó közlekedési kapcsolatokat, a magas vendégéjszaka számot, a település turisztikai vonzerejét és az alapfokú intézményi ellátottságot, mint fejlesztő hatású tényezőt. Valamint a statisztikai vizsgálat tovább árnyalta ezeket, a vonalas infrastruktúra (különösen vezetékes gáz, csatornázottság és internetelérés) és az alacsony munkanélküliségi arány szükségességét igazolta.

A teljes faluállomány statisztikai vizsgálatában a fent említett tényezők abban az esetben eredményeztek sikeres aprófalut, ha több faktor együttes fejlettsége jellemezte a települést. Vagyis az aprófalvas statisztikai vizsgálat a tényezők komplexitásának fontosságát igazolta.

A lakossággal folytatott kérdőívezés során a sikeresség tényezői a nemzetiségi, ellátottsági értékek fontossága mellett a közösségi aktivitással, az élhető települési környezettel (természettel) és a polgármesterrel való aktív együttmüködés lehetőségével egészültek ki. A lakossági kérdöívekhez kapcsolódóan elvégzett, a vizsgálatba vont aprófalvak környékbeli falvaira vonatkozó statisztikai vizsgálat a települési sikeresség tényezőcsoportját a környékbeli települések fejlett voltával gazdagította. Azaz egy-egy sikeres aprófalu közvetlen környezetében is statisztikailag fejlettebb települések 
helyezkednek el, bár köztük a kölcsönhatás autokorrelációs vizsgálattal nem mutatható ki.

A polgármesterekkel és a helyi elit tagjaival folytatott interjúkban a megkérdezettek a sikeresség tényezőiként olyan további faktorokat jelöltek meg, mint a településen zajló rendezvények közösségkovácsoló ereje, a magas pályázati hajlandóság, és a falu konfliktusmentessége. A legsikeresebb aprófalvak polgármesterei több cikluson keresztül polgármesterek, a település müködése zavartalan.

A disszertációban alkalmaztam továbbá két röviden ismertetett, de hasznos eredményeket hozó módszert. Ezek közül egyik, a fotódokumentáció elemzés a rendezett településképpel és a környezettudatosság fontosságával egészítette ki a sikerességi tényezők körét, másik, az épületállomány felmérés a lakóépületek, üdülők, kereskedelmi és egyéb ingatlanok állagmegóvásának szükségességét eredményezte újabb sikerességi tényezőnek (11. táblázat - 7. sz. melléklet).

Az ,aprófalvas szindróma” tünetcsoportja a szakirodalomban jól ismert jelenség, a tényezőcsoport a fejletlen, depresszív területek aprófalvait jellemzi. A kutatásban többféle módszerrel, többféle érték mentén lehatárolt sikerességi tényezők a dinamikus aprófalvas térségek, fejlődő falvak tényezőcsoportját adják. Úgy vélem a szakirodalomból eddig hiányzó, a depresszív térségek ellenpólusaként megjelenő dinamikus területek tényezőinek lehatárolása legalább ennyire fontos. Ezek alapján a dinamikusan fejlődő aprófalvak tünetcsoportja az alábbiakban foglalható össze:

Dinamikus aprófalvak tényezöcsoportja: azt a kistelepülést tekintem dinamikusan fejlödö, sikeres aprófalunak, melyben az alábbiakban felsorolt tényezők legtöbbje együttesen teljesül. E tényezők között a sikeres aprófaluban jelen vannak olyan faktorok, amelyeket a falu nem, vagy csak kis mértékben tud befolyásolni, így pl. az, hogy a falu lakosságszáma nem csökken (szélsőséges esetben oly mértékben nö, hogy kikerül az aprófalu kategóriájából), összfejlettségét tekintve a teljes faluállományon belül magas értékekkel jellemezhetö, általában a nyugati országrészben, vagy valamely országos jelentöségü turisztikai attrakció közelében helyezkedik el, közlekedési kapcsolatai jók, alapfokú ellátottsága kielégítö. A sikeres aprófaluban vannak olyan sikerességi faktorok is, melyekre a falu lakosságának erös a befolyásoló hatása, ezek szükséges, de nem elégséges kritériumok. így pl. a falu társadalma és a helyi elit tagjai tevékenyek, a lakosság gondot fordít az épületállomány állapotának megörzésére és a környezet védelmére, valamint hajlandó a környező településekkel való együttmüködésre. 
Az irodalmi előzmények, a statisztikai és empirikus vizsgálat eredményei alapján a sikeres és fejletlen aprófalu fejlődési útjai között is megfigyelhetők különbségek, melyek az alábbiakban adhatók meg (14. ábra):

A sikeres aprófalu lineáris úton halad a településvezetés és lakosság által megfogalmazott célok elérése felé. A településen rejlő potenciál(oka)t a falu lehetőségeihez mérten kiaknázza, legyen az a lakossági összefogásban, nemzetiségi értékekben, turisztikai adottságokban, városközelségben rejlő potenciál. A hátráltató tényezőket a sikeres falvak igyekeznek minimálisra csökkenteni, felismerve azt, hogy a legalacsonyabb fejlettségi értékekkel rendelkező területek fejlesztése is szükséges, ami lehet pl. ellátottságbeli, infrastrukturális tényezőkben, közlekedési kapcsolatokban megmutatkozó elmaradás.

A fejletlen aprófaluban ezzel szemben nem egyértelmủek a kitüzött célok, így a település fejlődése nem lineáris úton halad. A nem egyértelmü célok kapcsán a meglévő potenciálok sem hasznosulnak, a hátráltató tényezők fejlesztése háttérbe szorul, a településvezetés csak egy-két kitüntetett terület fejlesztésére összpontosít, ami nem elegendő a fejlődéshez.

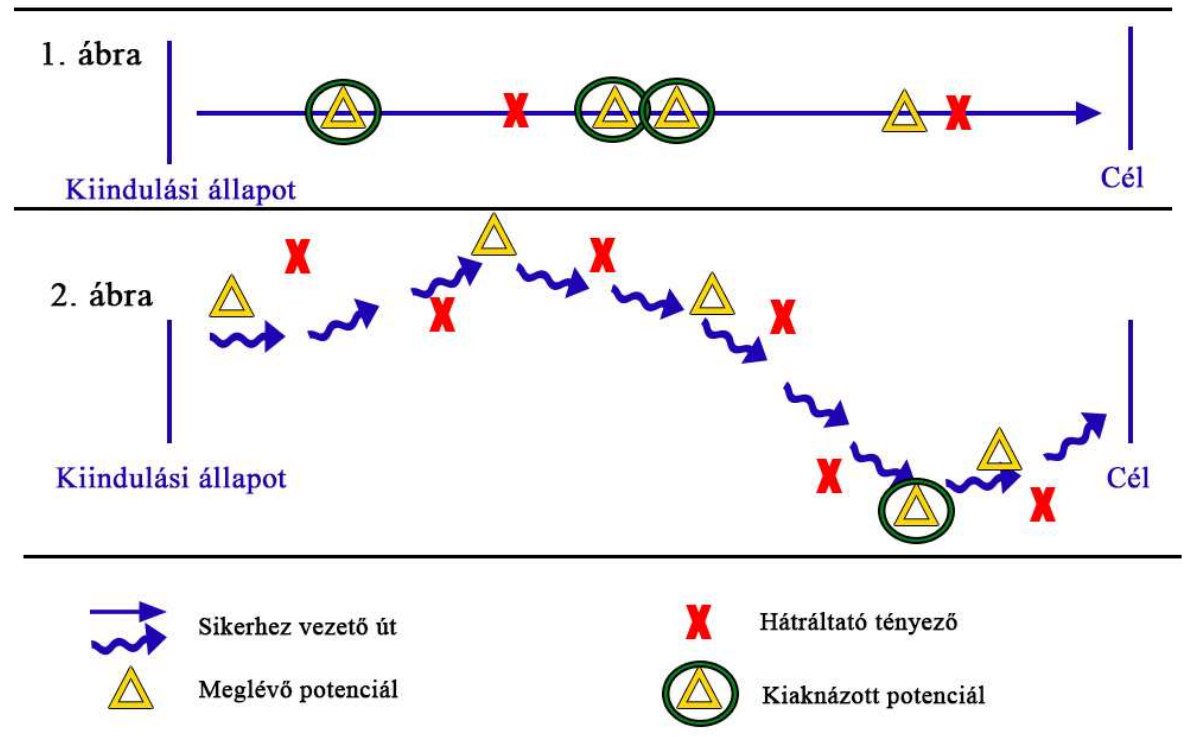

14. ábra. Az aprófalu sikerességéhez vezető út egy sikeres és egy fejletlen kistelepülés példáján

(Forrás: saját szerkesztés)

Úgy vélem, a disszertációban „kívülről” és „,belülről” mérő módszerekkel vizsgált aprófalvak közül Szántód, Fertöhomok, Dunaszentmiklós és Hegymagas esetében igazolható az előbbi, lineáris vonalon történő fejlődés. Szántód esetében a fejlődés 
egyenes útját a turisztikai adottságok kiaknázása jelentette. E mellett ellátottsági, közlekedési, szolgáltatási mutatóinak értékei magasak. A lakosság kötődik a faluhoz, szeretnek ott élni, a lakóépületeket és az üdülőket is karbantartják. Az üdülöfalu jellegből eredő konfliktusokat a településvezetés kezelni tudja.

Gosztola, Dozmat, Dörgicse, Csonkahegyhát, Villánykövesd, Tivadar, Apátistvánfalva, Velemér és Romonya annak ellenére, hogy számos tényező tekintetében kimagasló értékekkel jellemezhető falvak, nem az egyenes fejlödési utat követik, vagy csak egy tényező fejlesztésére fókuszálnak. A sajátos helyzetü Gosztola szállodafejlesztése a lineáris utat követi ugyan, de a település vezetése mindent saját ízlésére formál, a kevés számú megkérdezett a kérdőívezés során elégedetlen volt, a többség inkább elzárkózott a véleménynyilvánítástól. Csonkahegyháton nincs egyértelmü fejlesztési irány. A falu hiába rendelkezik intézményekkel, és jó közlekedési kapcsolatokkal, körjegyzőségi központ volta ellenére községi honlapja nincs, az épületállomány állagát tekintve az egyik legrosszabb helyzetü a vizsgált falvak között.

Alsómocsolád és még inkább Klárafalva, valamint Fony [7] egy-egy sikerességi tényezőjük ellenére inkább a nem lineáris fejlődési úton haladó, inkább már fejletlennek nevezhető aprófalvak közé sorolhatók. Alsómocsolád lakosai a helyben lévő gazdasági potenciál ellenére sem elégedettek, a településvezetés a lakosság közti kommunikáció problémás, a környék falvai is fejletlenek. Klárafalván hiába nagy a járatsürüség, ha a lakosok nem fordítanak figyelmet az utcaképre, az épületállomány állagmegőrzésére, és többen is az elköltözést helyezik kilátásba.

A kvantitatív és kvalitatív módszerekkel lehatárolt sikerességi tényezök és a falvakat jellemző fejlődési út különbözősége alapján úgy vélem, a sikeres aprófalu modellezhető. A disszertáció záró részében így a fent ismertetett eredmények tükrében egy, a sikeres aprófalut leíró modellt ismertetek.

\subsection{Az aprófalvak sikerességi modellje, különböző értékek szerint lehatárolt sikerességi tényezők alapján}

A megfelelő modell megalkotása során többféle megközelítésű modellt vizsgáltam. A legnagyobb publicisztikai aktivitás a sikeresség leginkább versenyszemléletű értelmezésével kapcsolatban fellelhető (ÁCS Z. - VARGA A. 2000, Krugman, P. 2000, Porter, M. E. 2000, Szirmai V. 2002). A dolgozat tartalmi keretei és a terepi felmérések eredményeinek hangsúlyossága azonban nem teszik lehetővé a 
versenyképesség modellezésére irányuló kutatások részletes ismertetését. Ezért a versenyképességi modellek közül kiválasztott és alapnak tekintett, a kutatási témába leginkább átadaptálható Lengyel-féle versenyképességi piramist ismertetem (LENGYEL I. 2000), mivel ez magába foglalja a Jensen-Butleri alapokat (JENSEN-BUTLER, C. 1999, hangsúlyozza a Trabold-féle modelltől (TRABOLD, H. 1995) való eltérést (az egymásra épülés kapcsán), ugyanakkor az Enyedi-féle városi sikerességi tényezőkre (ENYEDI GY. 1998) alapozva került kidolgozásra.

Az áttekintett modellek közül ez a modell tünt leginkább alkalmasnak arra, hogy a szakirodalomban fellelhető sikerességi tényezőket magába foglalva a „kívülröl” és „belülről” szemlélődő módszerek által lehatárolt sikerességi faktorokat is magába foglaló modell alapjául szolgáljon.

Ez a modell a régiókra és a nagyvárosokra alkalmazható leginkább, hiszen a középpontjában elhelyezkedő regionális és térségi jövedelem ezekben a léptékekben mérhető. Mégis azt gondolom, hogy a modell kiinduló alap lehet a falvak sikerességének modellezéséhez is, oly módon, hogy a piramis modell alapját képező tényezők egy része helyben marad, más része módosul, az alaptényezők pedig a modell központjában szereplő jövedelmi viszonyokkal együtt „kívülről” szemlélve kis részben változnak, módosulnak, ,belülről” szemlélve átalakulnak, a hangsúlyt a humán tőke felé tolva el.

A városok és különösen a falvak sikerességi tényezőit figyelembe véve és csoportosítva úgy vélem, a piramis csúcsán elhelyezkedő megfelelő életminőség és életszínvonal elérése a falvak sikeressége szempontjából csak részben helytálló. Megfelelő életminőséggel biztosítható az, hogy a település lakossága tudjon azonosulni falujával, jól érezze magát a településén, mindemellett több cikluson keresztül a polgármester személye és a képviselőtestület helyben maradása is ily módon lehetséges. Azonban a megfelelő életminőséget csak szükséges, de nem elégséges feltételnek tekintem a sikeres aprófaluban.

A korábbi fejezetekben lehatárolt sikerességi tényezők alapján a piramismodell alapját képező gazdasági szerkezet, társadalmi szerkezet, innovációs kultúra, döntési központok, regionális elérhetőség, a környezet minősége, a munkaerő felkészültsége és a régió társadalmi kohéziója alapfeltételek között két esetben a települési szintü sikeresség modellezésénél változtatás szükséges (15. ábra). 


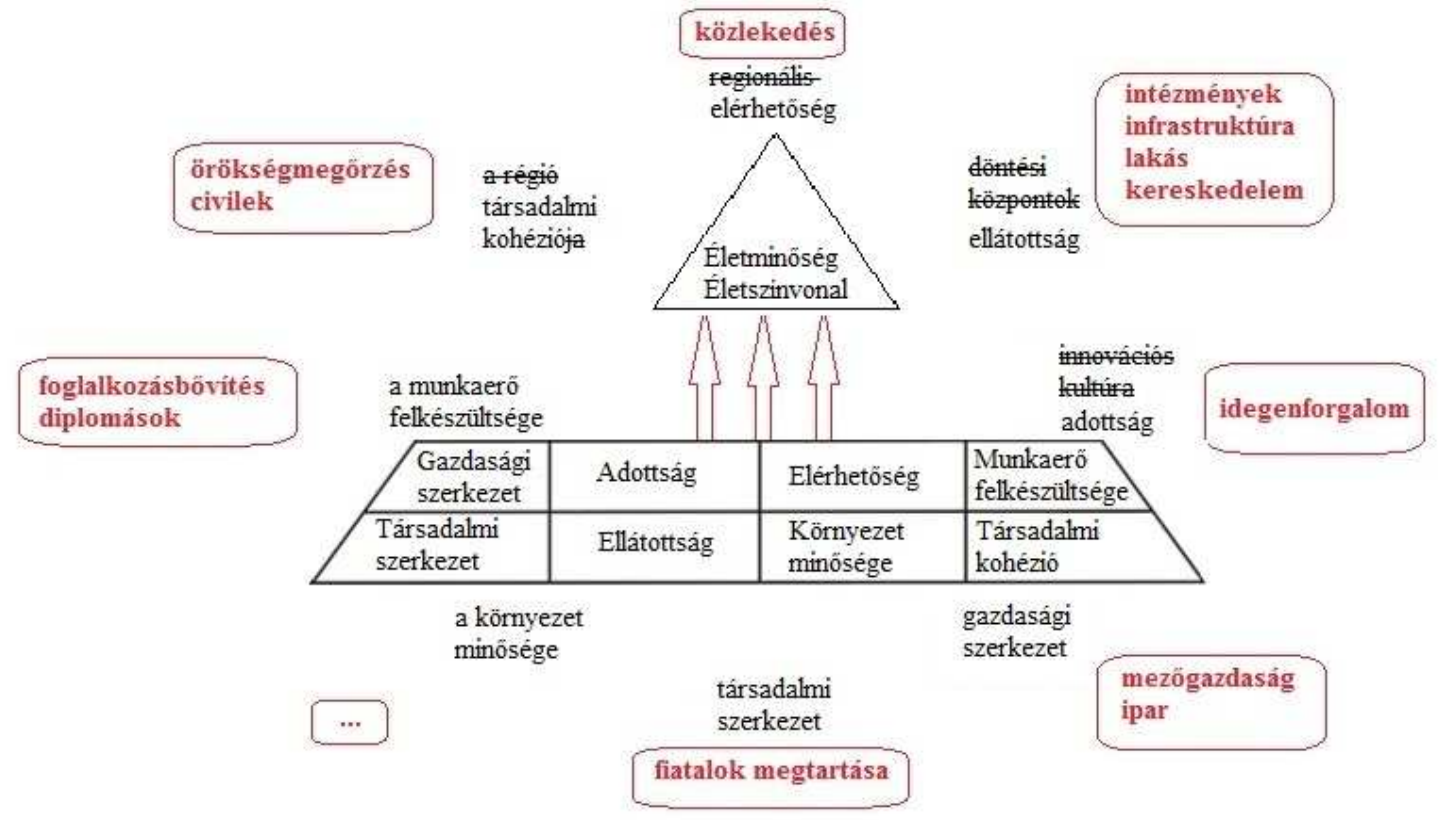

15. ábra. A versenyképességi piramismodell alapfeltételeinek módosulása a sikeres falu modelljének kidolgozása kapcsán

(Forrás: Lengyel I. 2000 alapján saját szerkesztés)

Az alapfeltételek között a döntési központok és az innovációs kultúra módosítását tartom szükségesnek. A lehatárolt sikerességi tényezők - az ábrán pirossal jelölve, keretezve - az elérhetőség, társadalmi kohézió, a munkaerő felkészültsége, a társadalmi szerkezet és gazdasági szerkezet alapfeltételek kategóriáiba jól illeszkednek, így ezeket az alapfeltételeket a falvak sikerességének modelljében is helytállónak tekintem.

Mivel a falvak sikerességének vizsgálatában az alapfokú intézmények, infrastrukturális ellátottság, a megfelelő lakásviszonyok és kereskedelmi egységek megléte, valamint a turisztikai adottságok kiaknázása fejlődést előidéző faktorként jelentkezett, ezért az alapfeltételek közé az ellátottságot és az adottságot helyezem be a döntési központ és innovációs kultúra alapfeltételek helyett. A környezet minősége alapfeltétel helytállósága leginkább a lakossági kérdőívek eredményeiben igazolódott.

Az eredeti modellnek a kistelepülésekre való alkalmazhatósága kapcsán a külföldi müködőtőke befektetés és a kutatás-fejlesztés alaptényezők módosítását is szükségesnek tartom. A helyi elit tagjaival folytatott interjúk alapján a település pályázati tevékenysége emelhető erre a szintre, ily módon a kutatás-fejlesztés megvalósulását, mint sikerességi tényezőt nem tekintem a falvak sikerességi modellje részének.

Szükségesnek tartom továbbá a modell társadalmi oldalról közelítő átdolgozását is. Ily módon az eredeti modell falvakra történő, társadalmi szemléletü alkalmazhatósága esetében a modell központjába a társadalom állítható. A disszertációban ismertetett, különböző módszerekkel lehatárolt sikerességi tényezők 
alapján úgy vélem, hogy a lakosság és a polgármester aktivitása, a polgármester nyitottsága a lakosság és környező települések irányába, valamint a lakosság egymást segítő magatartása, a társadalmi szemléletü modell központi elemei. E társadalmi szemléletü modell megalkotását azért sem tartom elhagyhatónak, mert az utóbbi években a települési fejlődés felé vezető úton a társadalmi tőke fontosságát több publikáció is kiemelten kezeli (CSÁTH M. 2008, GARELLI, S. 2008).

A lehatárolt sikerességi tényezőicsoport kapcsán kialakítható alapfeltételeket tehát a sikeres aprófalu modelljében az alábbiak adják: gazdasági szerkezet, társadalmi szerkezet, adottság, ellátottság, elérhetőség, környezet minősége, munkaerő felkészültsége, társadalmi kohézió. A humán tőke felértékelődése miatt azonban szükségesnek éreztem a modellt társadalmi szemlélettel is átformálni. Így a sikeres falu modelljének egy „kívülröl” és egy „belülről” meghatározott modelljét alakítottam ki, az alábbiak szerint (16. ábra).

A „kívülöl” mérhető sikerességi tényezők alapján a modell központjában a magas statisztikai összfejlettségi értékek állnak. Vagyis a kvantitatív úton könnyen mérhető mutatók alapján felállítható fejlettségi rangsorban elért minél elökelőbb hely szükséges a települési sikerességhez. A „belülről” mérhető sikerességi elemek között a társadalmi szerepvállalás értékelődik fel, mely a települési fejlődés mozgatója.

A kutatásban lehatárolt sikerességi tényezők alapján felállított modell egy, a statisztikai vizsgálatnál említett problémára ismét felhívja a figyelmet. A sikeres aprófalu valószínüsíthetően - népességszáma növekedése miatt - kiesik az aprófalvak kategóriájából. A fejlettségét eredményező faktorokat viszont megőrzi. Így a sikeres aprófalvakra kidolgozott modell sem csak az 500 fő alatti népességszámmal rendelkező falvakra alkalmazható, hanem mindazon falvakra, amelyek a dinamikus aprófalvak tünetcsoportjával jellemezhetőek. Átgondolásra érdemes lehet tehát az aprófalvak lélekszám szerint történő kategóriába sorolása. A kutatás több ízben is rámutat arra, hogy a falvak egyes csoportjainak funkciók szerinti elkülönítése is hasznos lehet további aprófalvas vizsgálatok során. 

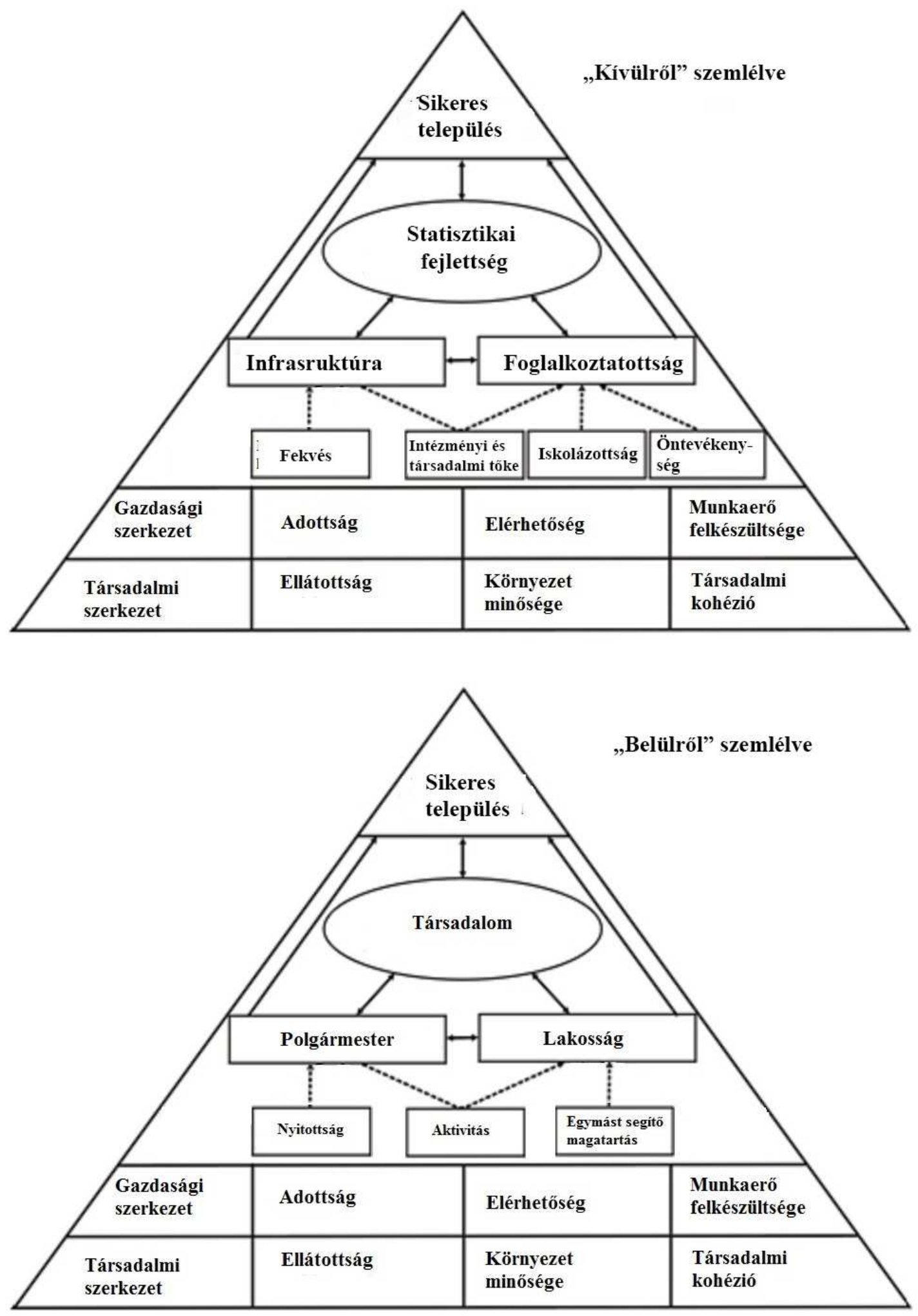

16. ábra. A falvak sikerességének piramis modellje (Forrás: Lengyel I. 2000 alapján saját szerkesztés) 


\section{ÖSSZEGZÉS}

Disszertációmban a fejlődő, sikeres aprófalvakat „kívülről”, statisztikai adatokkal mérve és „,belülről”, a helyi társadalom véleményét kutatva vizsgáltam. A falvak fejlődését segítő sikerességi tényezők lehatárolásához statisztikai adatelemzést, lakossági kérdőívezést, interjúkat, épületállomány vizsgálatot és fotódokumentáció elemzést használt fel. A sikerességi tényezők megadása mellett a disszertációban felvázoltam a falvak különböző fejlödési útjait, modelleztem a sikeres aprófalut, a fejlesztések lehetséges irányainak kijelölése érdekében.

Aprófalunak az 500 fönél nem népesebb településeket tekintettem. Ismertettem elterjedési területüket, valamint a településpolitikai döntésekhez igazodva, az 1950-es évektől folyamatosan változó differenciáló tényezőiket. A disszertációban bemutatásra kerültek a falvak különböző szempontú csoportosításai, valamint a depresszív térségeket jellemző ,,aprófalvas szindróma” tényezői.

A szakirodalomban megnevezett fejlődési faktorok feltárása érdekében áttekintettem hazai és nemzetközi irodalmakat. Értekeztem arról, hogy a sikeresség különböző értékek mentén mérhető, a sikerességi tényezők lehatárolásához különböző értékek mentén mért, komplex vizsgálat szükséges.

27 statisztikai mutató egységnormált értékeiből összfejlettségi adatokat állítottam fel az aprófalvas településállományra (1073 település) vonatkozóan. Az adatok egy része másodlagos adat volt, jelentős része viszont általam, településenként előállított, elsődleges adat. Annak érdekében, hogy a mutatócsoportok értékei közti eltérések nagysága mérhető legyen, az aprófalvak összfejlettségi helyezéseit is vizsgáltam. A statisztikai adatokkal lehatároltam az aprófalvak sikerességi tényezőit, ismertettem a legfejlettebb falvak elterjedési területét, külön figyelmet fordítottam a 2010-re aprófalu kategóriájába „,belefogyott” és aprófalu kategóriájából „kinőtt” falvakra.

Mivel az aprófalvas településállomány teljes faluállományon belüli helyzetének bemutatására eddig nem került sor, ezért elvégeztem a teljes faluállomány statisztikai vizsgálatát is (2935 település). Ugyancsak 27 mutató egységnormált értékeiből állítottam fel a falvak fejlettségi rangsorát. A fejlettségbeli különbségek mérhetősége érdekében az aprófalvak fejlettségi átlagértékeit, az 500 főnél népesebb falvak fejlettségi átlagértékeit és a teljes faluállomány fejlettségi átlagértékeit külön is mértem. Az átlagértékek helyezéseit az összfejlettségen belül a pontosítás érdekében szintén vizsgáltam. Az aprófalvak statisztikai vizsgálata során lehatárolt sikerességi tényezőket 
a teljes faluállomány statisztikai vizsgálatának eredményeivel összevetettem, a sikerességi tényezők körét módosítottam. A nemzetiségi tényező hangsúlyosságát statisztikai módszerekkel külön kutattam.

Mivel a disszertáció benyújtása előtt elérhetővé váltak a 2011-es népszámlálás adatai, az összfejlettségi értékeket a népszámlálási adatok felhasználásával (ahol szükséges volt) módosítottam, az eltéréseket a disszertációban közöltem.

A „kívülről” mért kutatás eredményeit egy, a hazai szakirodalomban kevésbé alkalmazott kutatási módszer, az épületállomány felmérés eredményeivel is kiegészítettem. Az épületállomány felmérése mellett a teljes faluállomány lakásépítési tendenciájának statisztikai vizsgálatával is foglalkoztam.

A statisztikai úton lehatárolt tényezők körét összehasonlítottam a helyi lakosság véleményével. A vizsgálatba vont falvakban és szomszédos településeiken közel 500 kérdőívet vettem fel. A lakossági kérdőívek eredményeit bővítettem egy 2013-ban zajlott fonyi szociálgeográfiai kérdőívezéssel. E mellett a vizsgálatba vont települések körül 20 km-es körzeten belül elhelyezkedő falvak statisztikai vizsgálatát is elvégeztem, valamint a vizsgált aprófalvak és környező falvaik fejlettsége közti összefüggéseket területi autokorrelációval vizsgáltam.

Másik empirikus kutatásom, vagyis a helyi elit tagjaival folytatott interjúk (24 interjú) tovább bővítették a sikerességi tényezők körét, valamint a fent említett vizsgálatok által lehatárolt számos sikerességi tényező helytállóságát is megerősítették. Hasonló eredményt adott a vizsgált falvakban müködő honlapok képi anyagának tartalomelemzése (1134 fénykép) is.

A fenti módszerek segítségével lehatároltam a dinamikus aprófalvak tényezőit, ismertettem a falvak fejlődési útjait, kialakítottam a sikeres aprófalu modelljét.

A kutatás elején megfogalmazott 3 fő kérdés közül az elsőre az alábbi választ adom. Az aprófalvak sikerességi tényezői folymatosan változnak. Azok a falvak maradnak sikeresek, amelyek egyrészt olyan tényezőkkel rendelkeznek, amelyek viszonylagosan állandóak, másrészt nem csak egy-két sikerességi faktorral jellemezhetők. A sikerességi tényezők köre igen sokrétü, és több faktor együttes jelenléte eredményez sikeres települést. Egyaránt fontos a lakosság megtartása, a gazdasági, társadalmi, ellátottsági, közlekedési és idegenforgalmi mutatók fejlettsége, a településvezetés és a lakosság aktivitása, a környezet és az építmények megóvása, valamint a környező településekkel való együttműködési hajlandóság. 
Második kérdésem a sikerességi tényezők lehatárolására alkalmas módszerekre irányult. Úgy vélem, a sikerességi faktorok lehatárolása éppen a siker többféle értelmezhetősége miatt komplex módszertant igényel. A kutatás eredményei igazolták a kvantitatív és kvalitatív módszerek alkalmazásának szükségességét is, hiszen valamennyi alkalmazott módszer hozott a vizsgálat szempontjából érdemi eredményt.

Harmadik kérdésem a sikeres aprófalu modellezhetőségére irányult. A többféle módszerrel meghatározott sikerességi tényezők és a szakirodalomban megtalálható sikermodellek összekapcsolásával a sikeres aprófalu modellezhető. További kérdés vet fel azonban az aprófalvak 500 fős lélekszámhatára. A kutatási eredmények alapján valószínüsíthető, hogy az aprófalvak sikerességének modellje a magasabb népességszámmal rendelkező falvak esetében is helytálló, tesztelése további kutatás kiindulópontja lehet.

Kiinduló hipotézisem, mely szerint a lakosság, a helyi elit véleménye, és a statisztikai sikertényezők köre nem azonos, igazoltnak tekinthető. Korábbi alapfeltevésemet, - mely szerint a kérdőíves adatfelvétel, az interjúk, a statisztikai adatok, az épületállomány felmérés és a fotódokumentáció elemzése egymást kiegészítve és együttesen jelölik ki a sikerességi elemek körét - szintén fenntartom, és igazoltnak tekintem. Harmadik, egyben utolsó hipotézisemet, mely szerint a sikerességi tényezők többféle módszer együttes alkalmazássával komplexen lehatárolhatók, valamint a sikeres falu modellje felállítható, a disszertációban elvégzett kutatás eredmenyei szintén igazolták.

A megfogalmazott célok teljesítésére vonatkozóan az új kutatási eredmények közlésével adok választ:

—A nagy számban rendelkezésre álló aprófalvakkal foglalkozó szakirodalom felhasználásával a disszertáció összefoglalja az aprófalvak fejlődését befolyásoló tényezők körét, és azok hangsúlyának módosulásait a településpolitika kialakulásától napjainkig.

— A disszertáció felvázolja az aprófalvas településállomány egészének fejlettségi helyzetét a teljes faluállományon belül.

— Az aprófalvak fejlődését, sikerességét eredményező tényezők körét kvantitatív és kvalitatív módszerekkel határoltam le.

— A disszertációban kialakításra kerül egy eddig nem meghatározott tényezőcsoport, a dinamikus aprófalvak tényezőcsoportja. 
— A disszertációban bemutatásra kerül egy gazdasági és társadalmi szemléletü sikerességi modell, az aprófalvak vonatkozásában.

—A kérdőíves felmérés eredményeinek szemléltetésére a disszertációban olyan komplex ábrát alkalmazok, mely egyszerre mutatja a vizsgálatba vont aprófalvak és azok szomszédos településeinek lakossági válaszait.

—A sikerességi tényezők feltárására a terepen végzett épületállomány felmérés, valamint a községi honlapok fotódokumentáció elemzésének módszerét is alkalmaztam.

—Végül a disszertációban röviden ismertettem a 2001-es és a 2011-es népszámlálások nemzetiségi és iskolázottsági adatainak eltérését, melyek e szempontok sikerességi tényezőként való megjelenését még inkább alátámasztották.

Kutatási eredményeim alapján javasolom a területfejlesztő szakemberek számára a helyi lakosság és helyi elit tagjainak a döntések előkészítésébe, a fejlesztési irányok kialakításába való aktívabb bevonását.

Javaslom továbbá a település valamennyi jellemzőjének (társadalom, gazdaság, ellátottság, infrastruktúra, közlekedési kapcsolatok, turisztikai adottságok, stb.) felmérése után nemcsak az erősséget (erősségeket) fejleszteni, hanem a legrosszabb értékekkel rendelkező, hátráltató tényezőket (amelyeket érdemben lehet) jelentősen javítani a település fejlődési pályára állítása érdekében.

Javaslom továbbá az aprófalvak definiálásánál a funkciók menti vizsgálatokat is, nem csupán a lélekszám szerinti elkülönítést. 


\section{SUMMARY}

In my Ph.D. thesis I examined the successful small villages 'from the outside' with the help of statistics, and 'from the inside', analyzing the opinion of the local society. To circumscribe the success factors that contribute to the development of villages I used statistical induction, residential questionnaires, interviews, building stock survey and photo documentation analysis. Besides defining the success-factors in my paper, I sketched some ways of village development, and modeled the successful small village for the sake of appointing possible directions of improvements.

I considered a small village as a village with no more than 500 residents. I showed the distribution area of small villages, as well as their differentiating factors that have been constantly changing from the 1950's, always adapting to the decisions in regional politics. In my thesis I presented a few groupings of the villages, and the factors of 'small village syndrome' that characterize depressive areas.

To reveal the development factors I surveyed Hungarian and international literature too. I also explained that the rate of success can be measured by different values, and to outline the success-factors, a complex analysis, based on the different values, is needed.

From the normalized values of 27 statistical indicators, I gained data regarding the total development of the small village stock (1073 settlements). A part of the data was secondary data, but most of them were primary, collected by myself, village by village. For the sake of the indicator group value differences being measurable, I also examined the total development ranks of small villages. By the statistics I outlined the success factors of small villages, I showed the distribution area of the most developed villages, and I paid special attention to the villages that had been 'running out' into the category of small village or 'outgrown' that category by 2010 .

As there has been no presentation of the situation of the small village stock examined within the whole village stock, I made a statistical analysis of the whole village stock (2935 villages) as well. I ranked the villages according to development, again using the normalized values of 27 indicators. For the sake of the measurability of some differences in development, I measured the development averages of the small villages, the development averages of the villages of more than 500 residents, and that of the whole village stock, separately as well. I also examined the rankings of averages, within the total development, in order to refine. I compared the outlined success factors gained from analyzing the statistics of small villages, with the results from the statistics 
of the whole village stock, and I modified the circle of success factors. I separately analyzed the significance of gentility factor by methods of statistic analysis.

As before the submission of my dissertation, the data of the 2011 census had been made accessible, by using the data of the census I modified the total development values (where it was necessary), and I showed the deflections in my paper.

I completed the results of the 'outside' survey with results of a research carried out by a method less known in Hungary: building stock analysis. Aside from analyzing the building stock, I also made a statistical analysis of the housing tendency of the whole village stock.

I compared the factors outlined with the help of statistical analysis, to the opinion of the local residents. I had nearly 500 questionnaires filled in the examined villages and their neighboring settlements. I expanded the results of these questionnaires by a 2013 social geographic questionnaire research made in Fony. Besides, I also made a statistical analysis of the surrounding villages of the researched ones within $20 \mathrm{~km}$ range, and I examined the development correspondence of the researched small villages and their surrounding villages, by regional autocorrelation.

My other empirical research: the interviews with the local elite (24 interviews) further expanded the circle of success factors, and they also confirmed the pertinence of numerous success factors outlined by the researches I explained in detail above. The image content analysis of the websites of the examined villages (1134 photographs) gave similar result.

With the above-mentioned methods I outlined the factors of dynamic small villages, I presented the ways of development for villages, and set up the model of the successful small village.

To the first of the three major questions formulated at the beginning of my research, I give the following answer. The success factors of the small villages are always changing. Those villages remain successful, that on the one hand have relatively persistent factors, on the other hand can be characterized with more than one or two success factors. The circle of success factors is truly diverse, and the collective presence of more factors makes a village successful. Retaining the residents, an advanced state of economy, society, supply, transport and tourism indicators, the activity of population and settlement management, the protection of environment and buildings, and the willingness to cooperate with surrounding settlements are also important. 
My second question was about the methods by which the success factors could be outlined. I think the outlined of success factors requires a complex methodology, because of understanding success in different ways. The research results justified the necessity of applying quantitative and qualitative methods too, as each method applied brought substantive results that were relevant to the examination.

My third question was regarding the modellability of the successful small village. By linking the success factors defined by various methods with the success models found in literature, the successful small village can be modeled. However a further question is raised regarding the population limit of 500, as being the population limit of small villages. Based on the research results, it is presumable that the success model of small villages can be expanded and applied on more populated villages too, its testing could be a starting point of further research.

My starting hypothesis, which states that the circle of success factors outlined by analyzing the statistics, those outlined by surveying the opinion of the residents and those outlined by examining the opinion of the local elite are not identical, turned out to be true. My earlier assumption that the questionnaires, the interviews, the statistics, the building stock analysis and the photo documentation review, altogether and completing one another, well mark out the circle of success factors, I also uphold and regard as justified. My third and last hypothesis that the circle of success factors can be outlined in a complex manner, by using some various methods collectively, and the assumption that the model of the successful small village can be set up, are also justified by the research results shown in the dissertation.

Regarding the phrased-above goals to be reached, I answer with presenting the new research results:

- By using the plenty of literature about small villages, in the dissertation I summarize the circle of factors that affects the development of small villages, and the modifications of their emphasis, from the early formation of settlement politics up to now.

- In my paper I delineated the development state of the whole small village stock within the whole village stock.

- The factors that lead to the development and success of small villages, I outlined by quantitative and qualitative methods.

- In the Ph.D. thesis, a factor group that has not been defined yet, is now being defined: the factor group of the dynamic small villages. 
- In the Ph.D. thesis, an economy and society centered success model is presented, regarding the small villages.

- To demonstrate the results drawn from the questionnaires, in the dissertation I apply a complex illustration that shows the residential answers of the examined small villages and also the neighboring settlements.

- In order to reveal the success factors, I also applied the method of surveying the building stock, carried out in the field, and photo documentation analysis of the settlement webpages.

- In the end, I briefly presented the differences between the 2001 and 2011 census, regarding the gentility and education data, which have even more supported that these two aspects could appear as success factors.

Based on my research results I suggest that regional development specialists should make the residents and the local elite participate more actively in the preparation of decisions, and the shaping up of development directions.

I also recommend that after surveying some of the settlement parameters (society, economics, supply, infrastructure, traffic ties, tourism conditions, etc.), not only the strong points should be developed, but the factors with the worst values, the retarding ones too, they can be significantly and substantively improved for the purpose of putting the settlement into a developing orbit.

In addition, I suggest some researches focusing on the functions as well, when defining a small village, not only differentiation by population size. 


\section{FELHASZNÁLT IRODALOM}

1. Andersson, A. 1985: Creativity and regional development. Papers of the Regional Science Association. pp. 5-20.

2. ANDORKA R. 1995: Homo socio-oeconomicus. A közgazdaságtan és a szociológia társadalmi és emberképe. Akadémiai kiadó, Budapest. 87 p.

3. ANTAL L. 1976: Tartalomelemzés alapjai. Magvető Kiadó, Budapest. 49 p.

4. AUBERT A. - ZSIBRIK I. 1984: Hozzászólás. In: SÜKÖSD F. szerk.: Az aprófalvak közélete és ifjúsága. Kisz Baranya megyei Bizottsága, Pécs. pp. 283-286.

5. Ashworth, G. J. - VoOgD, H. 1997: A város értékesitése: marketingszemlélet a közösségi célú várostervezésben. KJK, Budapest. 266 p.

6. ÁCs Z. - VARGA A. 2000: Térbeliség, endogén növekedés és innováció. Tér és Társadalom 4. pp. 23-39.

7. BABBIE, E. 2003: A társadalomtudományi kutatás módszertana. Balassi Kiadó, Budapest. 693 p.

8. BAJMÓCY P. - BALOGH A. 2002: Aprófalvas településállományunk differenciálódási folyamatai. Földrajzi Értesítő 3-4. pp. 385-405.

9. BAJMÓCY P. —BOROS L. 2004: Az aprófalvak népesedése 1949-től napjainkig. In: CSAPÓ T. - Kocsis Zs. - LENNER T. szerk.: A településföldrajz helyzete és föbb kutatási irányai az ezredforduló után. I. Településföldrajzi Konferencia. Savaria University Press, Szombathely. pp. 61-79.

10. BAJMÓCY, P. - JÓZSA, K. 2008: Impacts of tourism on the population change trends of the villages in Hungary. Sustainable Tourism Development in the Carpathians Mountains. The First International Carpathians Tourism Conference. Universitara Housing Press, Bucharest. pp. 139-145.

11. BAJMÓCY P. - JóZSA K. - PóCSI G. 2007: Szélsőséges aprófalvak. Aprófalvak a településlisták végein néhány társadalmi-gazdasági mutató alapján. - In: CsAPÓ T. - Kocsis ZS. szerk.: A kistelepülések helyzete és településföldrajza Magyarországon. III. Településföldrajzi Konferencia. Savaria University Press, Szombathely. pp. 83-101.

12. BALOGH A. 2004: Az aprófalvasodás idő- és térbeli sajátosságai Magyarországon. In: Abonyiné P. J. - KomareK L. szerk.: 40 éves a Szegedi Tudományegyetem Gazdaság- és Társadalomföldrajz Tanszéke. SZTE Gazdaság- és Társadalomföldrajz Tanszék, Szeged. pp. 113-119.

13. BAlogh A. 2008: Az aprófalvas településállomány differenciálódási folyamatai Magyarországon. Savaria University Press, Szombathely. 105 p.

14. BANDUR, A. 1986: Social Foundations of Thought and Action: A Social Cognition Theory. Prentice Hall, New Yersey. pp. 243-249.

15. Baumont, C. - ERTur, C.- Le GAllo, J. 2001: A Spatial Econometric Analyis of Geographic Spillovers and Growth for European Regions, 1980-1995. LATECDocument de travail-Economie. 2001/4. Universite de Bourgogne, Dijon. 28 p.

16. BELÉNYI GY. 1996: Az alföldi városok és a településpolitika: 1945-1963. Csongrád megyei levéltár, Szeged. 204 p.

17. BELUSZKY P. 1984: A kisfalvakról - településtudományi megközelítésben. In: SÜKÖSD F. szerk.: Az aprófalvak közélete és ifjúsága. Kisz Baranya megyei Bizottsága, Pécs. pp. 72-91.

18. BELUSZKY P. 2007: Új irányok a magyarországi falufejlődésben. In: CsAPÓ T. Kocsis Zs. szerk.: A kistelepülések helyzete és településföldrajza Magyarországon. III. Településföldrajzi Konferencia. Savaria University Press, Szombathely. pp. 5-14. 
19. BELUSZKY P. - GYŐRI R. 2006: A magyar városhálózat funkcionális versenyképessége. In: HORVÁTH GY. szerk.: Régiók és települések versenyképessége. MTA RKK, Pécs. pp. 236-294.

20. BELUSZKY P. - SIKOS T. T. 1982: Magyarország falutípusai. MTA Földrajztudományi Kutató Intézet, Budapest. 167 p.

21. BeluszKy P. - SiKOS T. T. 2007: Változó falvaink. Magyarország falutípusai az ezredfordulón. MTA Társadalomkutató Központ, Budapest. 459 p.

22. Benevolo, L. 1994: A város Európa történetében. Atlantisz Kiadó, Budapest. 245 p.

23. Berelson, B. 1952: Content Analysis. Free Press, New York. 18. p.

24. BERTA GY. 2005: Törpefalvak 100 fö alatt - Interjú 12 Veszprém megyei kisközség polgármesterével. Comitatus - önkormányzati szemle. 15. évf. 1-2. sz. pp. 80-87.

25. Bocz J. 1996: Az önkormányzatok döntéshozói, 1994. KSH, Budapest. 78 p.

26. BoCZ J. 2004: Újraválasztott polgármesterek, avagy kiket és miért választanak meg ismét a szavazópolgárok? Századvég, 2004. 3. szám. pp. 99-117.

27. BOROS L. 2003: A sikeres városok vizsgálatának lehetőségei. In: KIS M. GulYÁs L. szerk.: Európai kihívások 2. Tudományos Konferencia. SZTE-SZÉF, Szeged. pp. 317-320.

28. Boros L. - Hegedüs G. - PÁL V. 2007: A neoliberális településpolitika konfliktusai. - IN: OROSZ Z. - FAZEKAS I. szerk.: Települési Környezet Konferencia. Debreceni Egyetemi és Nemzeti Könyvtár Kossuth Egyetemi Kiadója, Debrecen. pp. 196-204.

29. Boulding, K. 1963: Conflict and Defense: A General Theory. Harper and Row, New York. 366 p.

30. BóDi F. 2000: Sikeres helyi társadalmak, sikeres térségi integrációk. In: KovÁCS T. szerk.: Integrált vidékfejlesztés. V. Falukonferencia. MTA Regionális Kutatások Központja, Pécs. pp. 450-457.

31. BóDi F. - BóDI M. 2011: Hol vannak a választók? Politikatudományi Szemle XX/1. MTA Politikai Tudományok Intézete, Budapest. pp. 51-74.

32. BóDI F. - BöHM A. 2000: Sikeres helyi társadalmak Magyarországon. Agroinform Kiadóház, Budapest. 179 p.

33. BöHM A. 1993: Rendszerváltás vagy elitváltás a helyi hatalomban. In: KovÁCs T. szerk.: Kiút a válságból. II. Falukonferencia. MTA Regionális Kutatások Központja, Pécs. pp. 241-244.

34. BöHM A. 1999: A helyi társadalomfejlődés dilemmái. In: PóCs GY. szerk.: Vidékfejlesztés-Vidékpolitika. Agroinform Kiadóház, Budapest 374 p.

35. Burges, E. W. 1929: Urban areas. In: SMITH, T. W. - WhITE, L. D. eds.: Chicago an experiment in social science research. University of Chicago Press, Chicago. $283 \mathrm{p}$.

36. CsAPÓ T. 1993: A rendszerváltás hatása a Nyugat-Dunántúl aprófalvas településeire. In: KovÁcs T. szerk.: Kiút a válságból. II. Falukonferencia. MTA Regionális Kutatások Központja, Pécs. pp. 275-280.

37. CsAPó T. - SzABÓ G. 1997: Vas megye falusi turizmusa. Comitatus. 7. 12. pp. 4754.

38. CSATÁRI B. 1993: Az alföldi falusi önkormányzatok önképe. In: KovÁCS T. szerk.: Kiút a válságból. II. Falukonferencia. MTA Regionális Kutatások Központja, Pécs. pp. 179-183.

39. CSATÁRI B. 2004: A területfejlesztés és vidékfejlesztés kapcsolata. MTA RKK ATI, Kecskemét. 151 p. 
40. CsÁth M. 2008: A Magyar Versenyképesség és „puha tényezői”. Valóság. LI. évf. 11. sz. pp. 1-13.

41. CSERTA O. - NOVÁK Z. - VÖRÖS L. 2004: A Vas megyei törpefalvak sajátosságai és lehetőségei. Területi Statisztika 7. 44. évf. 1-6. sz. pp. 137-151

42. CsORDÁs L. - SzABÓ G. 1993: A falusi-tanyai turizmus szervezésének és fejlesztésének feltételei az Alföldön. Alföldi Tanulmányok. 15. pp. 137-161.

43. DAHRENDORF, R. 1994: A modern társadalmi konfliktus. Gondolat, Budapest. 330 p.

44. D'ARCY, É. - GuISSANI, B. 1996: Local economic development: changing the parameters? Entrepreneurship \& Regional Development: An International Journal. Volume 8. Issue 2. pp. 159-178.

45. Denters, B. R. - LAWrence, E. 2005: Comparing Local Governance. Trends and Developments. Palgrave Macmillan, Hampshire. 293 p.

46. DobA Sz. 2009: A LEADER-szerü tervezés tapasztalatai a zalai aprófalvakban. In: MAJOROs P. szerk.: Tudományos évkönyv 2009. Válság és megújulás. BGF, Budapest. pp. 163-177.

47. DövÉNYI Z. 2003: A településrendszer fejlődése és sajátosságai. In: PERCZEL GY. szerk.: Magyarország társadalmi-gazdasági földrajza. ELTE Eötvös Kiadó, Budapest. pp. 521-532.

48. DURó A. 2012: Utak és találkozások: a tanyavilág vonzásában. In: PÁL V. szerk.: A társadalomföldrajz lokális és globális kérdései: Tiszteletkötet Dr. Mészáros Rezsö professzor 70. születésnapja alkalmából. SZTE-TTIK Gazdaság- és Társadalomföldrajz Tanszék, Szeged. pp. 11-22.

49. Egedy T. - KovÁcs Z. - SzÉKELY G. - SZEMZÖ H. 2002: Városrehabilitációs programok eredményei és tapasztalatai Budapesten. A NEHOM-projekt aktuális eredményei. Falu Város Régió. 8. pp. 3-10.

50. ENYEDI Gy. 1980: Falvaink sorsa. Magvető kiadó, Budapest. 183 p.

51. ENYEDI GY. 1984: Az aprófalvak szerepe a társadalmi munkamegosztásban. In: SüKÖSD F. szerk.: Az aprófalvak közélete és ifjúsága. Kisz Baranya megyei Bizottsága, Pécs. pp. 16-22.

52. ENYEDI GY. 1996: Regionális folyamatok Magyarországon. Hilscher Rezső Szociálpolitikai Egyesület, Budapest. 138 p.

53. ENYEDI Gy. 1997: A sikeres város. Tér és Társadalom 4. pp. 1-8.

54. ENYEDI GY. 1998: Sikeres régiók. In: KERESZTY A. szerk.: Tények könyve: régiók. Greger-Delacroix, Budapest. pp. 409-411.

55. ERDEI F. 1940: Magyar falu. Athenaeum, Budapest. 238 p.

56. ERDÖSI F. 1984: A törpefalvak közlekedési ellátottsága. In: SÜKÖSD F. szerk.: $A z$ aprófalvak közélete és ifjúsága. Kisz Baranya megyei Bizottsága, Pécs. pp. 227233.

57. FALus I. 2001: Bevezetés a pedagógiai kutatás módszereibe. Müszaki Könyvkiadó, Budapest. 540 p.

58. FARAGÓ L. 1993: Az elmaradott falusias térségek központi támogatásának gondjai. In: Kovács T. szerk.: Kiút a válságból. II. Falukonferencia. MTA Regionális Kutatások Központja, Pécs. pp. 167-175.

59. FERTŐ I. - LÉNÁRT ZS. - MAURER GY. - WinkLER T. 1990: A siker titka: a magánerős modernizáció. Tér és Társadalom 1. pp. 89-102.

60. Fickermann, D. - Weishaupt, H. - ZedLeR, P. 1998: Kleine Grundschulen in Europa. Deutscher Studienverlag, Weinheim. 357. p.

61. FLEISCHER T. 1991: Kistelepülések térben és időben. In: KovÁCs T. szerk.: Válság és kiút. Falukonferencia. MTA RKK, Pécs. pp. 88-96. 
62. FluSSER, V. 1990: A fotográfia filozófiája. Belvedere-Tartóshullám-ELTE BTK, Budapest. 70 p.

63. FORRAY R. K. 1995: Önkormányzatok és kisiskolák. Educatio. 1. pp. 70-81.

64. FöLdES A. 1999: Az interjú. Útmutató Kiadó, Budapest. 128. p.

65. FuKUYAMA, F. 2007: Bizalom. Európa Kiadó, Budapest. 615 p.

66. GARELli, S. 2008: Competitiveness 20 years later In: World Competitiveness Yearbook, IMD International, Lausanne. pp. 29-34.

67. GÁsPÁr G. 1986: Hat falu hat sorsa. Dr. Haller Média Kiadó, Pécs. 110 p.

68. G. FEKETE É. 1993: A kistérségi szövetségek szerepe a területfejlesztésben. In: KovÁCS T. szerk.: Kiút a válságból. II. Falukonferencia. MTA Regionális Kutatások Központja, Pécs. pp. 225-230.

69. G. FeKETE É. 2001: Aprófalvak az ezredfordulón - A Cserehát-Hernád-Bódva vidék. In: DORMÁNy G. - KOVÁCs F. - PÉTI M. - RAKONCZAI J. szerk.: A földrajz eredményei az új évezred küszöbén. I. Magyar Földrajzi Konferencia. CD-ROM. SZTE TTK Természeti Földrajzi Tanszék. Szeged. pp. 1-15.

70. GidDENS, A. 2002: Szociológia. Osiris Könyvkiadó, Budapest. 771 p.

71. GYÖRFFY I. 1943: Magyar falu, magyar ház. Turul Kiadó, Budapest. 231 p.

72. GYURICZA L. 1998: Természeti és társadalmi adottságok idegenforgalmi szempontú értékelése és komplex turisztikai kiskörzetek kialakítása Nyugat-Zala példáján. Földrajzi Értesítö XLVII. évf. 2. füzet. pp. 173-187.

73. HAJDÚ Z. 2005: Magyarország közigazgatási földrajza. Dialog Campus Kiadó, Budapest-Pécs. 332 p.

74. HANUSZ Á. 2002: A falusi turizmus elméleti kérdései és fejlesztési lehetőségei Szabolcs-Szatmár-Bereg megyében. Természettudományi Közlemények. 2. pp. 127-138.

75. Harris, C. D. - Ullman, E. L. 1945: The nature of cities. Annals of the American Academie for Political Science. Vol. 242. pp. 7-12.

76. Herbert, D. - Smith, D. M. 1989: Social Problems and the City. Oxford University Press, Oxford. 399 p.

77. HÉRA G. - Ligeti Gy. 2006: Módszertan. Osiris Kiadó, Budapest. 371 p.

78. HoYT, H. 1939: The structure and growth of residental neigborhoods in American cities. Federal Housing, Washington. 178 p.

79. HUBAI J. 1992: Magyarország eröforrásainak geográfiája. Tankönyvkiadó, Budapest. 119 p.

80. INOTAI A. - VERESS J. 2004: Hogyan lehetünk sikeres tagjai az Európai Uniónak? Mühelytanulmányok 58. MTA Világgazdasági Kutatóintézet, Budapest. 19 p.

81. IZSÁK É. 1999: A települési sorrend megváltozása a szuburbanizációs index alapján a budapesti agglomerációban. Földrajzi Értesítö XLVIII. évf. 1-2 füzet. pp. 83-92.

82. JANIS, I. L. 1965: Language of Politics: Studies in Quantitative Semantics. MIT Press, Cambridge. 412 p.

83. JENSEN - BUTLER, C. 1997: Competition between cities, urban performance and the role of urban policy: a theoretical framework. In: JENSEN-BUTLER, C. SHACHAR, A. - VAN WEESEP, J. eds.: European cities in competition Aldershot. Avebury. pp. 3-43.

84. Jensen-ButLer, C. 1999: Cities in Competition: Equity Issues. Urban Studies. 56. pp. 865-891.

85. JoHN, P. 2001: Local Governance in Western Europe. SAGE Publications Ltd., London. 602 p.

86. JÓZSA K. 2008: A társadalmi-gazdasági differenciáltság statisztikai elemzése Magyarország nagyközségeiben. - In: CsAPó T. - KocsIS Zs. szerk.: 
Nagyközségek és kisvárosok a térben. IV. Településföldrajzi Konferencia. Savaria University Press, Szombathely. pp. 195-208.

87. HALl, E. T. 1987: Rejtett dimenziók. Gondolat Könyvkiadó, Budapest. 275 p.

88. KING, D. S. 1990: Economic activity and the challenge to local government. In: KING, D. S.- PIERRE, J. eds.: Challenges to Local Government. SAGE Publications Ltd., London. pp. 265-287.

89. KISS J. P. 2008: Az aprófalvasodás és aprófalvaink sorsa - történelmi metszetben. In: VÁRADI M. szerk.: Kistelepülések lépéskényszerben. MTA Regionális Kutatások Központja, Új Mandátum Könyvkiadó, Budapest. pp. 29-69.

90. Kiss J. P. - LŐCSI H. 2005: Kistérségtípusok a Tisza mentén. In: NeMES N. J. szerk.: Régiók távolról és közelröl. Regionális Tudományi Tanulmányok 12. sz. ELTE, Budapest. pp. 83-143.

91. Klinger A. 1976: A községek népességszámának jellemzői. In: KulCSÁR V. szerk.: A változó falu. Gondolat Kiadó, Budapest. pp. 46-48.

92. KopASz M. 2004: Lakóhelyi szegregáció és társadalmi feszültségek a magyarországi településeken. In: KolOSI T. - TóTH I. GY. - VuKOVICH GY. szerk.: Társadalmi riport. TÁRKI, Budapest. pp. 414-424.

93. KopP M. - KovÁCs M. 2006: A magyar népesség életminősége az ezredfordulón. Semmelweis Kiadó. Budapest. 552 p.

94. Kotics J. 2007: A magyar közösségkutatások XX. századi története. In: KovÁcs É. szerk.: Közööségkutatás. Századvég, Budapest. pp. 120-138.

95. KovÁcs É. 2007: Közösségtanulmány. Módszertani jegyzet. Néprajzi Múzeum PTE-BTK, Kommunikáció és Médiatudományi Tanszék, Pécs. 438 p.

96. KovÁCS K. 1999: A szuburbanizációs folyamatok a fővárosban és a budapesti agglomerációban. In: BARTA GY. - BELUSZKY P. szerk.: Társadalmi-gazdasági átalakulás a budapesti agglomerációban. MTA RKK, Budapest. 255 p.

97. KovÁcs T. 1984: Az aprófalvak társadalmi jellemzői. Az ifjúság helyzete az aprófalvakban. In: SüKÖSD F. szerk.: Az aprófalvak közélete és ifjúsága. Kisz Baranya megyei Bizottsága, Pécs. pp. 142-153.

98. KovÁCS T. 2000: Vidék, vidékfejlesztés, vidékpolitika. Gazdálkodás. XLIV évf. 3. sz. pp. 11-20.

99. KovÁCs T. 2004: Aprófalvainkról illúziók nélkül. Területi Statisztika 7. 44. évf. 1-6. sz. pp. 125-136.

100. KóRÓDI J. 2004: A magyar falvak megújulásának stratégiája. Területi Statisztika 7. 44. évf. 2. sz. pp. 107-124.

101. KÖRMENDI K. 1976 a: Alaprajzi típusok. In: KulCSÁR V. szerk.: A változó falu. Gondolat Kiadó, Budapest. pp. 114-120.

102. KÖRMENDI K. 1976 b: Nagyságrendi típusok. In: KULCSÁr V. szerk.: A változó falu. Gondolat Kiadó, Budapest. pp. 91-113.

103. KÖRMENDI K. - KulCSÁR V. 1976: A falvak továbbfejlődésének irányai és problémái. In: KULCSÁR V. szerk.: A változó falu. Gondolat Kiadó, Budapest. pp. 320-334.

104. KÖSZEGFALVI GY. 1984: Az aprófalvak ellátása. A helyi és a körzeti intézményhálózat adottságai. In: SÜKÖSD F. szerk.: Az aprófalvak közélete és ifjúsága. Kisz Baranya megyei Bizottsága, Pécs. pp. 208-216.

105. KöSzEgfalvi Gy. - Tóтн J. 2002: Általános településföldrajz. In: TóTH J. szerk.: Általános társadalomföldrajz I. Dialóg Campus Kiadó, Budapest - Pécs. pp. 385448.

106. KöSzegfalvi Gy. - LoydL T. 2001: Településfejlesztés. ELTE Eötvös Kiadó, Budapest. 196 p. 
107. K. Somogyi G. 2000: Foglalkoztatási problémák egy sikeres kistérségben. In: KovÁcs T. szerk.: Integrált vidékfejlesztés. V. Falukonferencia. MTA Regionális Kutatások Központja, Pécs. pp. 499-509.

108. KRIPPENDORFF, K. 1995: A tartalomelemzés módszertanának alapjai. Balassi Kiadó, Budapest. 208 p.

109. Krugman, P. 2000: Where in the Word is the „New Economic Geography”. In: Clark, G. L. - Feldman, M. P. - Gertler, M. S. eds.: The Oxford Handbook of Economic Geography. Oxford University Press, New York. pp. 49-60.

110. Kulcsár V. 1976: Gazdasági típusok. In: KulcSÁr V. szerk.: A változó falu. Gondolat Kiadó, Budapest. pp. 120-128.

111. KunT, E. 2003: Az antropológia keresése. L'Harmattan Kiadó, Budapest. 240 p.

112. LACKÓ L. 1992 a: Magyarország természeti, népesedési, gazdasági települési és igazgatási viszonyainak főbb vonásai. In: LACKÓ L. szerk.: Települési ismeretek. Államigazgatási főiskola házinyomdája, Budapest. pp. 115-140.

113. LACKÓ L. 1992 b: Helyi településpolitika. In: LACKÓ L. szerk.: Települési ismeretek. Államigazgatási főiskola házinyomdája, Budapest. pp. 236-248.

114. LÁNYI A. 2007: A fenntartható társadalom. L'Harmattan Kiadó, Budapest. 75 p.

115. LÁSZLÓ GY. 1944: A honfoglaló magyar nép élete. Magyar Élet, Budapest. 512 p.

116. Le Gales, P. 2002: European Cities: Social Conflicts and Governance. Oxford University Press, Oxford. 344 p.

117. LENGYEL I. 2000: A regionális versenyképességről. Közgazdasági szemle. XLVII. évf. pp. 962-987.

118. LENGYEL I. 2003: Verseny és területi fejlödés: térségek versenyképessége Magyarországon. JATE-Press, Szeged. 454 p.

119. LENGYEL I. - RECHNITZER J. 2000: A városok versenyképességéröl. In: HoRVÁTH GY. - RECHNIZTER J. szerk.: Magyarország területi szerkezete és folyamatai az ezredfordulón. MTA RKK, Pécs. pp. 130-152.

120. LETTRICH E. 1975: Településhálózat, urbanizáció, igazgatás. MTA Állam- és Jogtudományi Intézet, Budapest. 96 p.

121. LEVEL, W. F. 1993: Competition within the European urban system. Urban Studies 30. pp. 935-948.

122. LOVASS K. A. 2006: A rendszerváltozás utáni gazdálkodó magatartásformák és üzemszervezetek néprajzi vizsgálata. Bölcsész Konzorcium HEFOP Iroda, Budapest. $130 \mathrm{p}$.

123. LuKÁCs G. S. 2008: Sikeres vidék. Szaktudás Kiadó Ház, Budapest. 223 p.

124. MADARÁsz I. 2011: Városszociológia. Gödöllő. 131 p.

125. Majoros P. 2004: A kutatásmódszertan alapjai. Perfekt Kiadó, Budapest. 250 p.

126. MARY, N. L. 2008: Social Work in a Sustainable World. Lyceum Books, Illinois. $240 \mathrm{p}$.

127. MENDÖL T. 1963: Általános településföldrajz. Akadémiai Kiadó, Budapest. 567 p.

128. MÉSZÁROS R. 1993: A falu sorsának belső területfejlődési összefüggése. In: KovÁCS T. szerk.: Kiút a válságból. II. Falukonferencia. MTA Regionális Kutatások Központja, Pécs. pp. 176-178.

129. MoHos M. 1984: Hozzászólás. In: SüKÖSD F. szerk.: Az aprófalvak közélete és ifjúsága. Kisz Baranya megyei Bizottsága, Pécs. pp. 189-192.

130. MoHos M. 1996: Az 500 fönél kisebb népességü falvak szociálgeográfiai vizsgálata. In: VUICS T. szerk.: Válogatott tanulmányok Magyarország társadalomföldrajzából. Egyetemi jegyzet, Pécs. pp. 15-42.

131. MOLNÁR L.-NÉ. 1970: The Major Trends of Social Change in Hungarian Villages. MTA KESZ Sokszorosító, Budapest. 17 p. 
132. NAGY K. 1976: A népességmozgás fö jellemzői 1950 után. In: KULCSÁR V. szerk.: A változó falu. Gondolat Kiadó, Budapest. pp. 55-68.

133. NAGYVÁRAdi L. - SZEBÉNYI A. 2008: Kozármisleny - egy sikeres kisváros Baranya megyében. In: CsAPÓ T. - Kocsis Zs. szerk.: Nagyközségek és kisvárosok a térben. IV. Településföldrajzi Konferencia. Szombathely. pp. 264276.

134. NEMES N. J. 1993: A városi gazdasági átalakulás hatása a falvakra. In: KovÁcs T. szerk.: Kiút a válságból. II. Falukonferencia. MTA Regionális Kutatások Központja, Pécs. pp. 24-29.

135. NEMES N. J. 1997: Régiók, regionalizmus. Educatio 3. pp. 407-423.

136. NYITRAI I. 1984: Az ifjúság helyzete az aprófalvakban; a KISZ lehetőségei és feladatai körükben. In: SüKÖSD F. szerk.: Az aprófalvak közélete és ifjúsága. Kisz Baranya megyei Bizottsága, Pécs. pp. 40-48.

137. Orosz B. 1999: Az épített örökség védelmének szerepe a falumegújításban Magyarországon. Falu Város Régió. 6. sz. pp. 9-13.

138. Orova M. 2006: A helyi önkormányzati együttmüködések, társulások az Európai Unió tagállamaiban. Kézirat. pp. 12-46.

139. P. KovÁCS. I. 1993: A szabadság kevés. In: KovÁCs T. szerk.: Kiút a válságból. II. Falukonferencia. MTA Regionális Kutatások Központja, Pécs. pp. 237-240.

140. PERCZEL K. - GeRle Gy. 1966: Regionális tervezés és a magyar településhálózat. Akadémiai Kiadó, Budapest. 445 p.

141. PERÉNYI I. - FARAgÓ K. - MAJOR J. 1962: Mezögazdaság és településtervezés. Müszaki Könyvkiadó, Budapest. 212 p.

142. Porter, M. E. 2000: Locations, Clusters, and Company Strategy. In: Clark, G. L. - FEldMAN, M. P. - GERTLER, M. S. eds.: The Oxford Handbook of Economic Geography. Oxford University Press, New York. pp. 253-274.

143. PRISTYÁK E. 2004: Beregi települések idegenforgalmának alakulása az elmúlt években a statisztikai adatok tükrében. Természettudományi Közlemények. 2004. 4. pp. 239-250.

144. RAY, C. 2000: The EU LEADER programme: rural development laboratory. Sociologia Ruralis 40. pp. 163-172.

145. SÁRI I. 2001: A „,sikeres” város. Falu Város Régió 3. pp. 25-26.

146. SÁRKÁNY M. 2000: Közösségtanulmányok és összehasonlításuk lehetőségei. In: SÁRKÁNY M. szerk.: Kalandozások a 20. századi kulturális antropológiában. L'Harmattan Kiadó, Budapest. pp. 56-71.

147. Sikos T. T. 1990: A lakossági infrastruktúra problematikája az aprófalvas térségekben. In: TóTH J. szerk.: Tér-Idö-Társadalom. Huszonegy tanulmány Enyedi Györgynek. MTA RKK, Pécs. pp. 304-315.

148. StARR K. - White S. 2008: The Small Rural School Principalship: Key Challenges and Cross-School Responses. Journal of Research in Rural Education. Vol. 23. pp. 1-12.

149. SÜLI-ZAKAR I. 1993: Vállalkozók és családi vállalkozások Kelet-Magyarország átalakuló mezőgazdaságában. In: KovÁCs T. szerk.: Kiút a válságból. II. Falukonferencia. MTA Regionális Kutatások Központja, Pécs. pp. 118-122.

150. SZÉKELY GY. 2006: Az aprófalvak népességmegtartó képességének állapota, változásai, irányai, illetve javításának lehetőségei. Facilitátor Bt, Budapest. 25 p.

151. SZIRMAI V. 2002: Verseny és/vagy együttmüködés?: város és környéke kapcsolatai. MTA Szociológiai Intézet, Budapest-Székesfehérvár. 233 p.

152. SzTOMPKA, P. 2009: Vizuális szociológia. A fényképezés mint kutatási módszer. Gondolat Kiadó-PTE Kommunikáció- és Médiatudományi Tanszék, PécsBudapest. 212 p. 
153. TAMÁSKA M. 2011: A vidéki tér emlékezete. Az építészeti formaképzödéstöl a kulturális örökségalkotásig. Nagykarácsony, Sukoró és Tiszafüred esettanulmányával. Martin Opitz Kiadó, Budapest. 202 p.

154. TÁLl É. 2000: A helyi vezetők szerepe az önkormányzatok sikerességében. In: KovÁcs T. szerk.: Integrált vidékfejlesztés. V. Falukonferencia. MTA Regionális Kutatások Központja, Pécs. pp. 458-462.

155. TIMÁr J. 1999: Elméleti kérdések a szuburbanizációról. Földrajzi Értesítő. XLVIII évf. 1-2. füzet. pp. 7-31.

156. TIMÁR J. 2007: Társadalmi nemek, aprófalu- és közösségtanulmányok. In: KovÁcs É. szerk.: Közösségtanulmány. Módszertani jegyzet. Néprajzi Múzeum PTE-BTK, Kommunikáció és Médiatudományi Tanszék, Pécs. pp. 115-133.

157. TIMÁR J. - VelKey G. 2003: Várossiker alföldi nézöpontból. MTA RKK ATI, MTA Társadalomkutató Központ, Békéscsaba-Budapest. 253 p.

158. TRABOLD, H. 1995: Die Internationale Wettbewerbsfähigkeit einer Volkwirtshaft. Vierteljahrshefte zur Wirtschaftsforschung. Vol. 64. Issue 2. pp. 169-183.

159. UTASI Á. 2006: A szubjektív életminőség forrásai: biztonság és kapcsolatok. MTA Politikai Tudományok Intézete. Budapest. 309 p.

160. VALÉR É. 1990: A települések társadalmi-funkcionális-müvi környezeti típusai és életútjai. In: VALÉR É. szerk.: A terület- és településfejlödés társadalmi-gazdasági folyamatai Magyarországon. OKKFT Ts-2/2 Program Iroda, Budapest. 39 p.

161. VÁGI G. 1985: Az aprófalvak társadalmi szerkezetének változásai. In: SÜKÖSD F. szerk.: Az aprófalvak közélete és ifjúsága. Kisz Baranya megyei Bizottsága, Pécs. pp. 165-174.

162. VÁRAdi M. M. 1997: Solymár: az aranyfalu. Tér és Társadalom 4. pp. 45-68.

163. VÁRAdI M. M. 1999: Hová megyünk lakni? Szuburbanizációs minták és konfliktusok a budapesti agglomeráció budai oldalán. In: BARTA GY. - BELUSZKY P. szerk.: Társadalmi-gazdasági átalakulás a budapesti agglomerációban. MTA RKK, Budapest. 255 p.

164. VIRÁG T. 2009: Szegények a kistelepülések fogságában - a szociálpolitika mindennapi gyakorlata egy hátrányos helyzetü térség településein. Esély 4. pp. 38-54.

165. VuICS T. 1984: Hozzászólás. In: SüKÖSD F. szerk.: Az aprófalvak közélete és ifjúsága. Kisz Baranya megyei Bizottsága, Pécs. pp. 286-288.

166. Wagner, J. 1979: Images of Information: Still Photography in the Social Sciences. SAGE Publications Ltd., London. 311 p.

167. WeBer, M. 2000: Gazdaság és társadalom. Közgazdasági és Jogi Könyvkiadó, Budapest. 373 p.

168. WINICZAI K. 2001: A sváb múlt nyomai Bóly társadalmában. Tér és Társadalom. XV. évf. 3-4. sz. pp. 153-166. 


\section{FORRÁSOK}

[1] http://alsomocsolad.hu/ (letöltve: 2009. szeptember 14-től folyamatosan)

[2] http://www.apatistvanfalva.hu/ (letöltve: 2009. szeptember 14-töl folyamatosan)

[3] http://www.dorgicse.hu/hu/polgarmester-koszonto (letöltve: 2009. szeptember 14-töl

folyamatosan)

[4] http://www.dozmat.hu/ (letöltve: 2009. szeptember 14-töl folyamatosan)

[5] http://www.dunaszentmiklos.hu/ (letöltve: 2009. szeptember 14-töl folyamatosan)

[6] http://www.fertohomok.hu/hu/hirek.html (letöltve: 2009. szeptember 14-töl

folyamatosan)

[7] http://www.fony.hu/ (letöltve: 2009. szeptember 14-töl folyamatosan)

[8] http://www.wellnesshotel-gosztola.hu/ (letöltve: 2009. szeptember 14., 2011. október 3-tól folyamatosan)

[9] http://www.hegymagas.hu/ (letöltve: 2009. szeptember 14-töl folyamatosan)

[10] http://www.hiszi-map.hu/ (letöltve: 2010. november 22.)

[11] http://www.klarafalva.hu/ (letöltve: 2009. szeptember 14-töl folyamatosan)

[12] http://www.ksh.hu/?lang=hu (letöltve: 2009. augusztus 02-től folyamatosan)

[13] Magyarország autóatlasza, 6. kiadás, Cartographia Kiadó, 2004

[14] Magyarország pálinkatérképe, Stiefel Eurocart Kft., 2009

[15] https://maps.google.com/ (letöltve: 2010. február 17-től folyamatosan)

[16] http://mav-start.hu/ (letöltve: 2010. február 17-töl folyamatosan)

[17] http://www.menetrendek.hu/ (letöltve: 2010. február 17-töl folyamatosan)

[18] http://nonprofit.hu/ (letöltve: 2010. február 17-töl folyamatosan)

[19] http://www.romonya.hu/ (letöltve: 2009. szeptember 14-töl folyamatosan)

[20] http://www.szantod.hu/ (letöltve: 2009. szeptember 14-töl folyamatosan)

[21] http://www.ksh.hu/apps/shop.kiadvany? p_kiadvany_id=1786 (letöltve: 2010. március 20.)

[22] http://www.tivadar.hu/ (letöltve: 2009. szeptember 14-től folyamatosan)

[23] http://velemer.hu/ (letöltve: 2009. szeptember 14-töl folyamatosan) 


\section{KÖSZÖNETNYILVÁNÍTÁS}

Köszönetemet fejezem ki a doktori dolgozat elkészítésében nyújtott segítségéért, hasznos tanácsaiért, témavezetői munkájáért Dr. Bajmócy Péter egyetemi docens úrnak.

Köszönettel tartozom továbbá Dr. Kovács Zoltán tanszékvezető professzor úrnak, aki biztosította a kutatáshoz szükséges feltételeket, észrevételeivel, javaslataival segítette munkámat.

Szintén köszönet illeti Dr. Mészáros Rezső professzor urat, valamint Dr. Csatári Bálint egyetemi docens urat, akik folyamatosan végigkísérték munkámat és ösztönöztek az elörehaladásra.

Köszönetemet fejezem ki továbbá Dr. Becsei József professzor úrnak, aki a doktori dolgozat megírásának kezdetén látott el hasznos tanácsaival a jegyzetkészítés módjára, a dolgozat könnyebb átláthatóságára vonatkozóan.

Köszönöm a segítséget Dr. Pál Viktor adjunktus úrnak, aki a doktori disszertáció megírásához elengedhetetlen statisztikai adatok egy részének eléréséhez nyújtott segítséget.

Köszönet illeti továbbá mindazokat a kollégákat, akik a doktori dolgozat alakulását kisebb nagyobb megszakításokkal nyomon követték, a doktori szeminárium keretein belül segítő észrevételeikkel, javaslataikkal, építő jellegü kritikai megjegyzéseikkel támogatták munkámat.

Köszönettel tartozom a lakossági kérdőívet kitöltő aprófalvak lakosainak, valamint interjúalanyaimnak, a települési polgármestereknek és a helyi elit tagjainak.

Köszönet illeti azokat az egyetemi hallgatókat, akik a terepi munka során a lakossági kérdőívek felvételében segítették munkámat. Balizs Dániel, Bottlik Mihály, Bozsó Nóra, Beihamer Csilla, Fekete Viktor, Gangl Éva, Gazsó Mihály, Gere Csilla, Györki Andrea, Hajdu Tímea, Iván Mónika, Jenei János, Kabódi Viktor, Kis Zoltán, Kocsis Márta, Kocsis Orsolya, Kolluti Gertrúd, Körmöczi Gábor, Lewadovski Ákos, Nagy-Tóth Zoltán, Orosz József, Péter Ágnes Petra, Rigó Zsuzsanna, Sinkó Evelin Ninetta, Sogrik Edina, Tobak László, Tóth Adrienn, Tóth Gábor Gyula, Veszelka Krisztina segítsége nélkül sem készülhetett volna el a disszertáció.

Végül köszönettel tartozom szüleimnek és páromnak, a disszertáció megírása közben nyújtott támogatásukért, valamint azért, hogy odafigyeléssel és türelemmel viseltettek irántam a disszertáció megírásának ideje alatt. 


\title{
MELLÉKLETEK
}

1. sz. melléklet: A vizsgálatba vont falvak kérdőíve

A válaszadás önkéntes és név nélküli!

\section{A kistelepülések problémái és perspektívái}

\author{
Lakossági kérdőív \\ Vizsgálatba vont falu
}

A kérdőív a Szegedi Tudományegyetem Gazdaság és Társadalomföldrajz Tanszéke „Sikeres aprófalvak” c. kutatásához készült. A kutatás célja a kistelepülések problémáinak, lehetséges fejlődési útjainak vizsgálata, a fejlődéshez, sikerességhez vezető tényezők feltárása.

A kérdőív a Szegedi Tudományegyetem Természettudományi és Informatikai

Karának Gazdaság- és Társadalomföldrajz Tanszéke számára készültt. A kérdőívben felvételre kerülő adatokat bizalmasan kezeljük.

\begin{tabular}{|c|l|l|l|l|l|l|l|l|l|}
\hline & & & Ideiglenes sorszám: & & & \\
\hline
\end{tabular}

Kérdezés kezdete:

év hónap nap óra perc

Kérdezés vége:

.év hónap nap óra perc

Kérdező neve:

A kutatás vezetőjének neve - Józsa Klára

A kutatás vezetőjének elérhetősége - E-mail: jozsak@geo.u-szeged.hu,Tel: 06-20/964-0544 


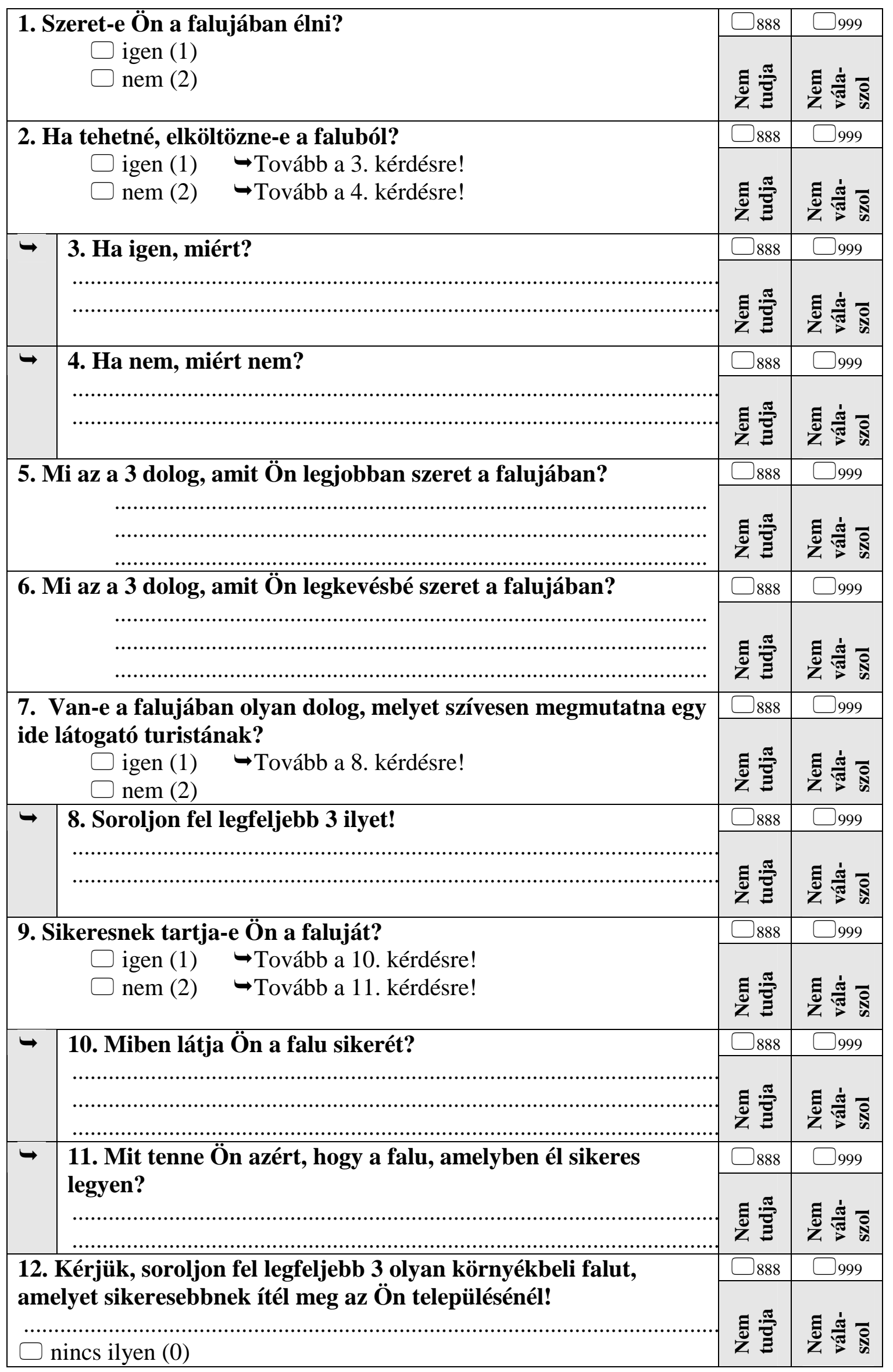




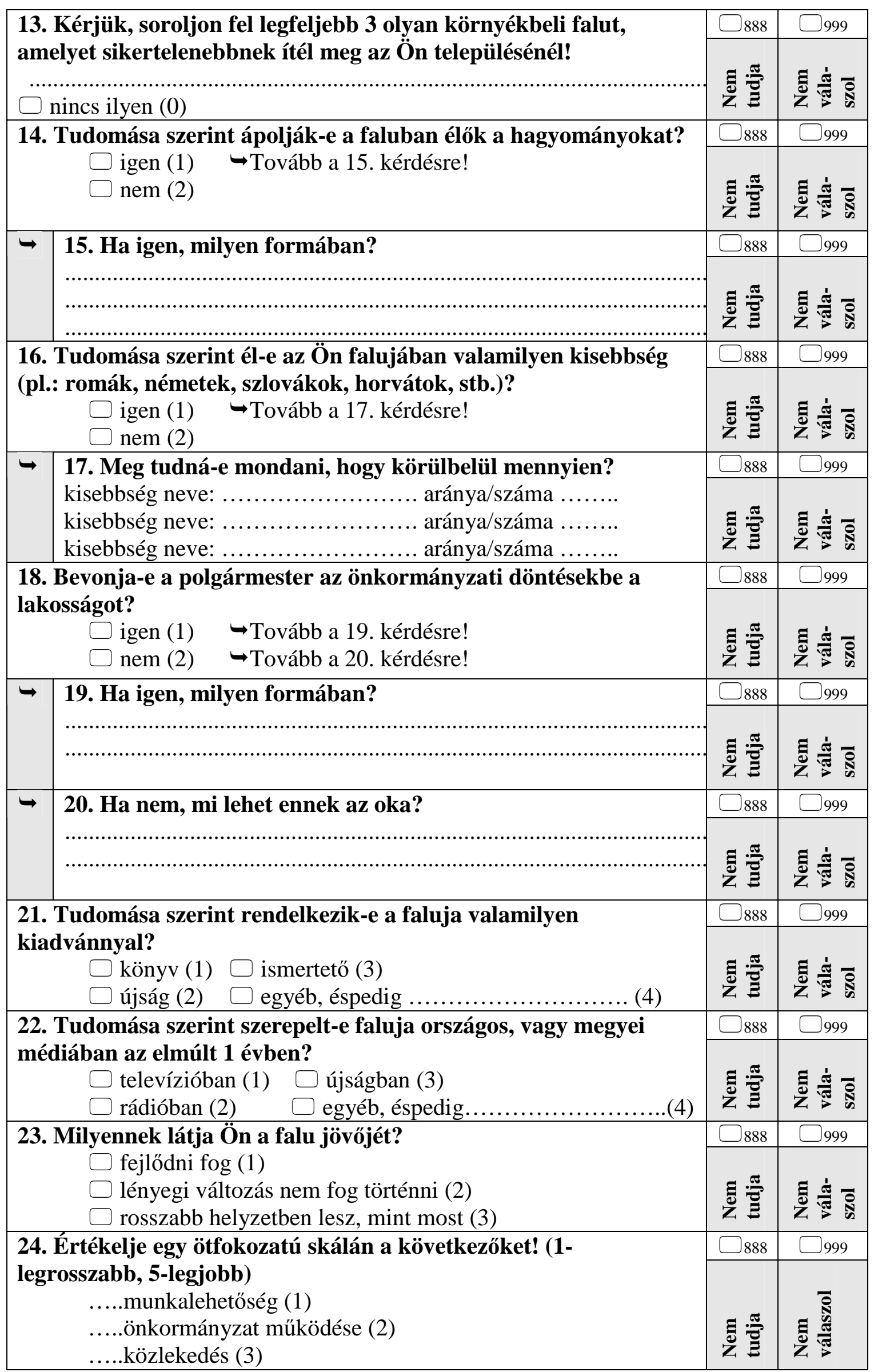




\begin{tabular}{|c|c|c|}
\hline \multirow{3}{*}{$\begin{array}{l}\text { 25. Mi az, amit még a település helyzetével, a falu jövőjével } \\
\text { kapcsolatban fontosnak tart elmondani? }\end{array}$} & \multirow{3}{*}{ そ气 } & \multirow{3}{*}{ 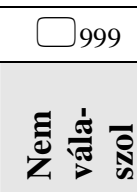 } \\
\hline & & \\
\hline & & \\
\hline \multirow[t]{2}{*}{ 26. Melyik évben született Ön: } & $\square 888$ & $\square 999$ \\
\hline & NT & $\mathbf{N V}$ \\
\hline \multirow[t]{2}{*}{ 27. Mi az Ön foglalkozása: } & $\square 888$ & $\square 999$ \\
\hline & NT & NV \\
\hline \multirow{2}{*}{$\begin{array}{l}\text { 28. Mi az Ön legmagasabb iskolai végzettsége: } \\
\begin{array}{ll}\square 8 \text { általánosnál kevesebb (1) } & \square 8 \text { általános (2) } \\
\square \text { szakmunkás (3) } & \square \text { érettségi (4) } \\
\square \text { technikum (5) } & \square \text { föiskola, egyetem(6) } \\
\square \text { egyéb, éspedig.................................... (7) }\end{array}\end{array}$} & $\square 888$ & $\square 999$ \\
\hline & 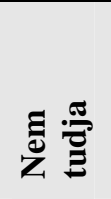 & 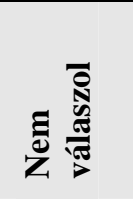 \\
\hline \multirow[b]{2}{*}{$\begin{array}{l}\text { 29. Mekkora az Ön háztartásának egy havi bevétele? } \\
\square 50.000 \text { Ft alatt (1) } \\
\square 80.000-110.000 \text { Ft között (3) } \square \text { ■110.000-80.000 Ft között (2) } \\
\square 140.000-170.000 \text { Ft között (5) } \square 170.000-200.000 \text { Ft között (4) } \\
\square 200.000 \text { Ft felett (7) }\end{array}$} & $\square 888$ & $\square 999$ \\
\hline & 鸹 & 宽 \\
\hline
\end{tabular}

KöSZÖNJÜK, HOGY VÁLASZADÁSÁVAL HOZZÁJÁRULT MUNKÁNKHOZ! 


\title{
A kistelepülések problémái és perspektívái
}

\author{
Lakossági kérdöív \\ Szomszédos település
}

A kérdőív a Szegedi Tudományegyetem Gazdaság és Társadalomföldrajz Tanszéke „Sikeres aprófalvak” c. kutatásához készült. A kutatás célja a kistelepülések problémáinak, lehetséges fejlődési útjainak vizsgálata, a fejlődéshez, sikerességhez vezető tényezők feltárása.

A kérdőív a Szegedi Tudományegyetem Természettudományi és Informatikai Karának Gazdaság- és Társadalomföldrajz Tanszéke számára készült. A kérdőívben felvételre kerülő adatokat bizalmasan kezeljük.

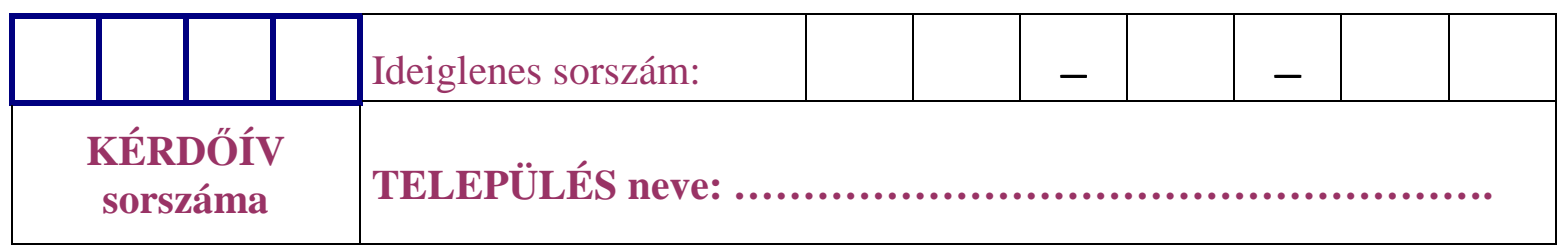

Kérdezés kezdete:

év hónap nap óra perc

Kérdezés vége:

.év hónap nap óra perc

\section{Kérdező neve:}

A kutatás vezetőjének neve - Józsa Klára

A kutatás vezetőjének elérhetősége - E-mail: jozsak@geo.u-szeged.hu,Tel: 06-20/964-0544 


\begin{tabular}{|c|c|c|c|}
\hline \multirow{2}{*}{\multicolumn{2}{|c|}{$\begin{array}{r}\text { 1. Szeret-e Ön : } \\
\square \text { igen }\end{array}$}} & $\square_{888}$ & $\square 999$ \\
\hline & & 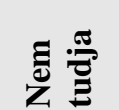 & 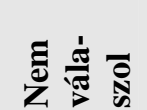 \\
\hline \multirow{2}{*}{\multicolumn{2}{|c|}{$\begin{array}{l}\text { 2. Ha tehetné, elköltöözne-e a faluból? } \\
\quad \square \text { igen (1) } \\
\square \text { nem (2) }\end{array}$}} & $\square_{888}$ & $\square 999$ \\
\hline & & 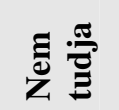 & 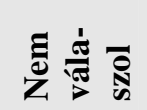 \\
\hline \multirow{2}{*}{\multicolumn{2}{|c|}{$\begin{array}{l}\text { 3. Ha tehetné, elkölttözne-e a szomszéd faluba? } \\
\square \text { igen (1) } \quad \begin{array}{l}\text { Tovább a 4. kérdésre! } \\
\square \text { nem (2) }\end{array}\end{array}$}} & $\square 888$ & $\square 999$ \\
\hline & & 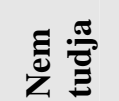 & 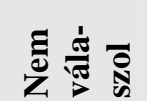 \\
\hline \multirow[t]{2}{*}{$\rightarrow$} & 4. Ha igen, miért? & $\square 888$ & $\square_{999}$ \\
\hline & $\cdots$ & 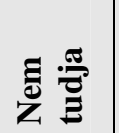 & 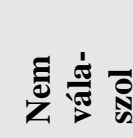 \\
\hline \multirow[t]{2}{*}{$\rightarrow$} & 5. Ha nem, miért nem? & $\square 888$ & $\square 999$ \\
\hline & & 㱐愛 & 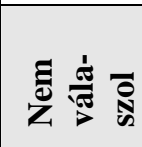 \\
\hline \multicolumn{2}{|r|}{ 6. Mi az a 3 dolog, amit Ön legjobban szeret a szomszéd faluban? } & $\square 888$ & $\square 999$ \\
\hline & (1) & 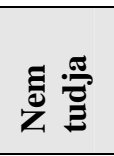 & 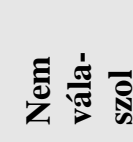 \\
\hline \multicolumn{2}{|r|}{ 7. Mi az a 3 dolog, amit Ön legkevésbé szeret a szomszéd faluban? } & $\square 888$ & $\square 999$ \\
\hline & (1) & 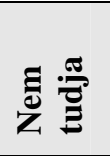 & 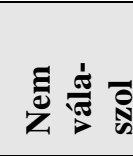 \\
\hline \multicolumn{2}{|r|}{$\begin{array}{l}\text { 8. Van-e a szomszéd faluban olyan dolog, melyet szívesen } \\
\text { megmutatna egy oda látogató turistának? }\end{array}$} & $\square_{888}$ & $\square 999$ \\
\hline \multicolumn{2}{|r|}{$\begin{array}{l}\square \text { igen (1) } \quad \rightarrow \text { Tovább a 9. kérdésre! } \\
\square \text { nem (2) }\end{array}$} & 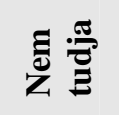 & 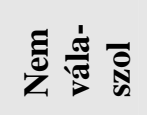 \\
\hline \multirow[t]{2}{*}{$\rightarrow$} & \multirow{2}{*}{ 9. Soroljon fel legfeljebb 3 ilyet! } & $\square_{888}$ & $\square 999$ \\
\hline & & 高焉 & 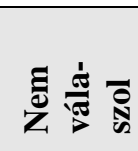 \\
\hline \multirow{2}{*}{\multicolumn{2}{|c|}{$\begin{array}{l}\text { 10. Sikeresnek tartja-e Ön a szomszéd falut? } \\
\quad \square \text { igen (1) } \\
\square \text { nem (2) }\end{array}$}} & $\square 888$ & $\square 999$ \\
\hline & & $\bar{z}$ & 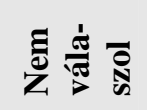 \\
\hline \multirow{2}{*}{\multicolumn{2}{|c|}{$\begin{array}{l}\text { 11. Sikeresebbnek ítéli-e meg Ön faluját a szomszéd falunál? } \\
\quad \square \text { igen (1) } \\
\square \text { nem (2) }\end{array}$}} & $\square_{888}$ & $\square 999$ \\
\hline & & $\tilde{z}$ & 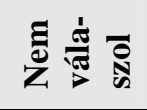 \\
\hline
\end{tabular}




\begin{tabular}{|c|c|c|c|}
\hline \multirow{2}{*}{\multicolumn{2}{|c|}{$\begin{array}{l}\text { 12. Tudomása szerint ápolják-e a szomszéd faluban élök a } \\
\text { hagyományokat? } \\
\square \text { igen (1) } \quad \rightarrow \text { Tovább a 13. kérdésre! } \\
\square \text { nem (2) }\end{array}$}} & \multirow{2}{*}{$\square 888$} & \multirow{2}{*}{$\square 999$} \\
\hline & & & \\
\hline \multirow[t]{2}{*}{$\Leftrightarrow$} & 13. Ha igen, milyen formában? & $\square 888$ & $\square 999$ \\
\hline & & そ̇ & 焉离 \\
\hline \multirow{2}{*}{\multicolumn{2}{|c|}{$\begin{array}{l}\text { 14. Tudomása szerint él-e a szomszéd faluban valamilyen } \\
\text { kisebbség (pl.: romák, németek, szlovákok, horvátok, stb.)? } \\
\square \text { igen (1) } \quad \rightarrow \text { Tovább a 15. kérdésre! } \\
\square \text { nem (2) }\end{array}$}} & $\square 888$ & $\square 999$ \\
\hline & & 㐏莺 & 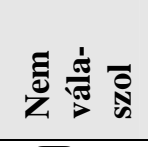 \\
\hline \multirow[t]{2}{*}{$\Leftrightarrow$} & \multirow{2}{*}{ 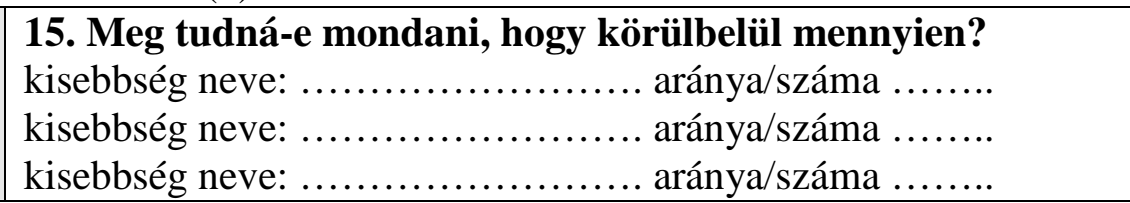 } & $\square 888$ & $\square 999$ \\
\hline & & ह & 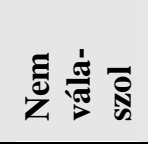 \\
\hline \multirow{2}{*}{\multicolumn{2}{|c|}{$\begin{array}{l}\text { 16. Bevonja-e a polgármester a szomszéd faluban az } \\
\text { önkormányzati döntésekbe a lakosságot? } \\
\square \text { igen (1) } \\
\square \text { nem (2) }\end{array}$}} & $\square 888$ & $\square_{999}$ \\
\hline & & 芯苛 & 苛离 \\
\hline \multirow{2}{*}{\multicolumn{2}{|c|}{$\begin{array}{l}\text { 17. Tudomása szerint rendelkezik-e a szomszéd falu valamilyen } \\
\text { kiadvánnyal? } \\
\qquad \begin{array}{l}\square \text { könyv (1) } \square \text { ismertető (3) } \\
\square \text { újság (2) } \square \text { egyéb, éspedig .................... (4) }\end{array}\end{array}$}} & $\square 888$ & $\square 999$ \\
\hline & & z & 苛离 \\
\hline \multirow{2}{*}{\multicolumn{2}{|c|}{$\begin{array}{l}\text { 18. Tudomása szerint szerepelt-e a szomszéd falu országos, vagy } \\
\text { megyei médiában az elmúlt } 1 \text { évben? } \\
\qquad \text { televízióban (1) } \square \text { újságban (3) } \\
\square \text { rádióban (2) } \square \text { egyéb, éspedig.................... (4) }\end{array}$}} & $\square 888$ & $\square 999$ \\
\hline & & 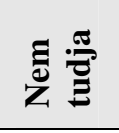 & 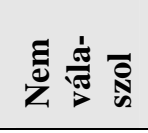 \\
\hline \multirow{2}{*}{\multicolumn{2}{|c|}{$\begin{array}{l}\text { 19. Milyennek látja Ön a falu jövőjét? } \\
\square \text { fejlödni fog (1) } \\
\square \text { lényegi változás nem fog történni (2) } \\
\square \text { rosszabb helyzetben lesz, mint most (3) }\end{array}$}} & $\square 888$ & $\square 999$ \\
\hline & & 竘 & 焉弯 \\
\hline \multirow{2}{*}{\multicolumn{2}{|c|}{$\begin{array}{l}\text { 20. Értékelje egy ötfokozatú skálán a következőket! (1- } \\
\text { legrosszabb, 5-legjobb) } \\
\text {....munkalehetőség (1) } \\
\text { …önkormányzat müködése (2) } \\
\text {....közlekedés (3) }\end{array}$}} & $\square 888$ & $\square 999$ \\
\hline & & そ & 竞 \\
\hline \multirow{2}{*}{\multicolumn{2}{|c|}{$\begin{array}{l}\text { 21. Mi az, amit még a szomszéd falu helyzetével, a szomszéd falu } \\
\text { jövőjével kapcsolatban fontosnak tart elmondani: }\end{array}$}} & $\square 888$ & $\square 999$ \\
\hline & & & 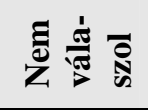 \\
\hline \multirow{2}{*}{\multicolumn{2}{|c|}{ 22. Melyik évben született Ön: }} & O888 & $\square 999$ \\
\hline & & NT & $\mathbf{N V}$ \\
\hline \multirow{2}{*}{\multicolumn{2}{|c|}{ 23. Mi az Ön foglalkozása: }} & & \\
\hline & & NT & NV \\
\hline
\end{tabular}




\begin{tabular}{|c|c|c|c|}
\hline \multicolumn{2}{|c|}{ 24. Mi az Ön legmagasabb iskolai végzettsége? } & $\square 888$ & $\square 999$ \\
\hline $\begin{array}{l}\square 8 \text { általánosnál kevesebb } \\
\square \text { szakmunkás (3) } \\
\square \text { technikum (5) } \\
\square \text { egyéb, éspedig.......... }\end{array}$ & $\begin{aligned} & \square 8 \text { általános (2) } \\
& \square \text { érettségi (4) } \\
& \square \text { föiskola, egyetem(6) }\end{aligned}$ & 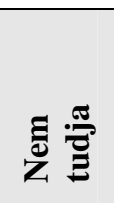 & 竞苞 \\
\hline \multicolumn{2}{|c|}{ 25. Mekkora az Ön háztartásának egy havi bevétele? } & $\square 888$ & $\square_{999}$ \\
\hline \multirow{3}{*}{\multicolumn{2}{|c|}{$\begin{array}{l}\square 50.000 \text { Ft alatt (1) } \square 50.000-80.000 \text { Ft között (2) } \\
\square \text { 80.000-110.000 Ft között (3) } \quad \square 110.000-140.000 \text { Ft között (4) } \\
\square \text { 140.000-170.000 Ft között (5) } \quad \square 170.000-200.000 \text { Ft között (6) } \\
\square \text { 200.000 Ft felett (7) }\end{array}$}} & & \multirow{3}{*}{ 离 } \\
\hline & & & \\
\hline & & 胥 & \\
\hline
\end{tabular}

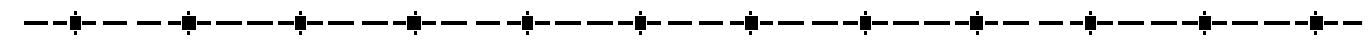

KÖSZÖNJÜK, HOGY VÁLASZADÁSÁVAL HOZZÁJÁRULT MUNKÁNKHOZ! 
A Gazdaság- és Társadalomföldrajz Tanszék 2013-as Borsod-Abaúj-Zemplén megye szociálgeográfiai felmérésének Erdőhorvátiban, Komlóskán, Háromhután, Mogyoróskán és Regécen felvett kérdőíveinek 50. kérdése:

50. Osztályozza az alábbi településeket a szerint, mennyire szimpatikusak Önnek!

(Egyáltalán nem szimpatikus - 1, nem szimpatikus - 2, szimpatikus - 3, nagyon szimpatikus - 4.)

Miskolc

$(1) \ldots(2) \ldots(3) \ldots(4)$

Sárospatak

(1)...(2)...(3)...(4)

Sátoraljaújhely

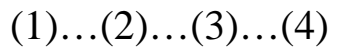

Erdőhorváti

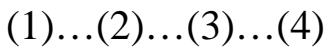

Tolcsva

(1)...(2)...(3)...(4)

Mogyoróska

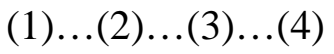

Regéc

(1)...(2)...(3)...(4)

Háromhuta

(1)...(2)...(3)...(4)

Komlóska

(1)...(2)...(3)...(4)

Fony

(1)...(2)...(3)...(4)

Gönc

(1)...(2)...(3)...(4)

Encs

(1)...(2)...(3)...(4)

Makkoshotyka.

(1)...(2)...(3)...(4)

Hercegkút

(1)...(2)...(3)...(4) 
4. sz. melléklet: A vizsgálatba vont faluhoz füződő kötődés és nemzetiségi jellemzők

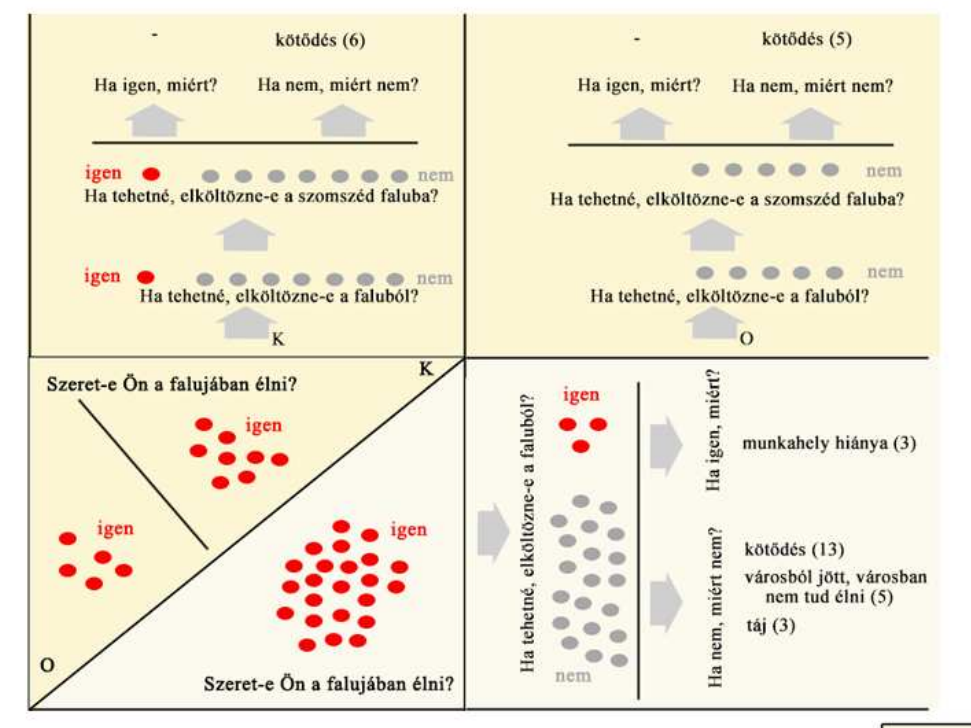

Jelmagyarázat

- egy lakos velemeneny

szomszédos falvak
lakosananak velemennenye

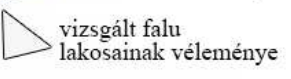

K Kétuolagy

O Orfalu

n.t. nem tudja

(1, 2, 3 stb.) egy lakos véleményc

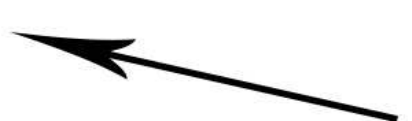

Szeret-

-

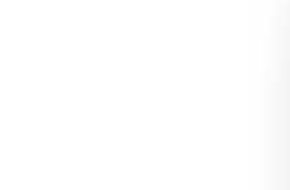

K
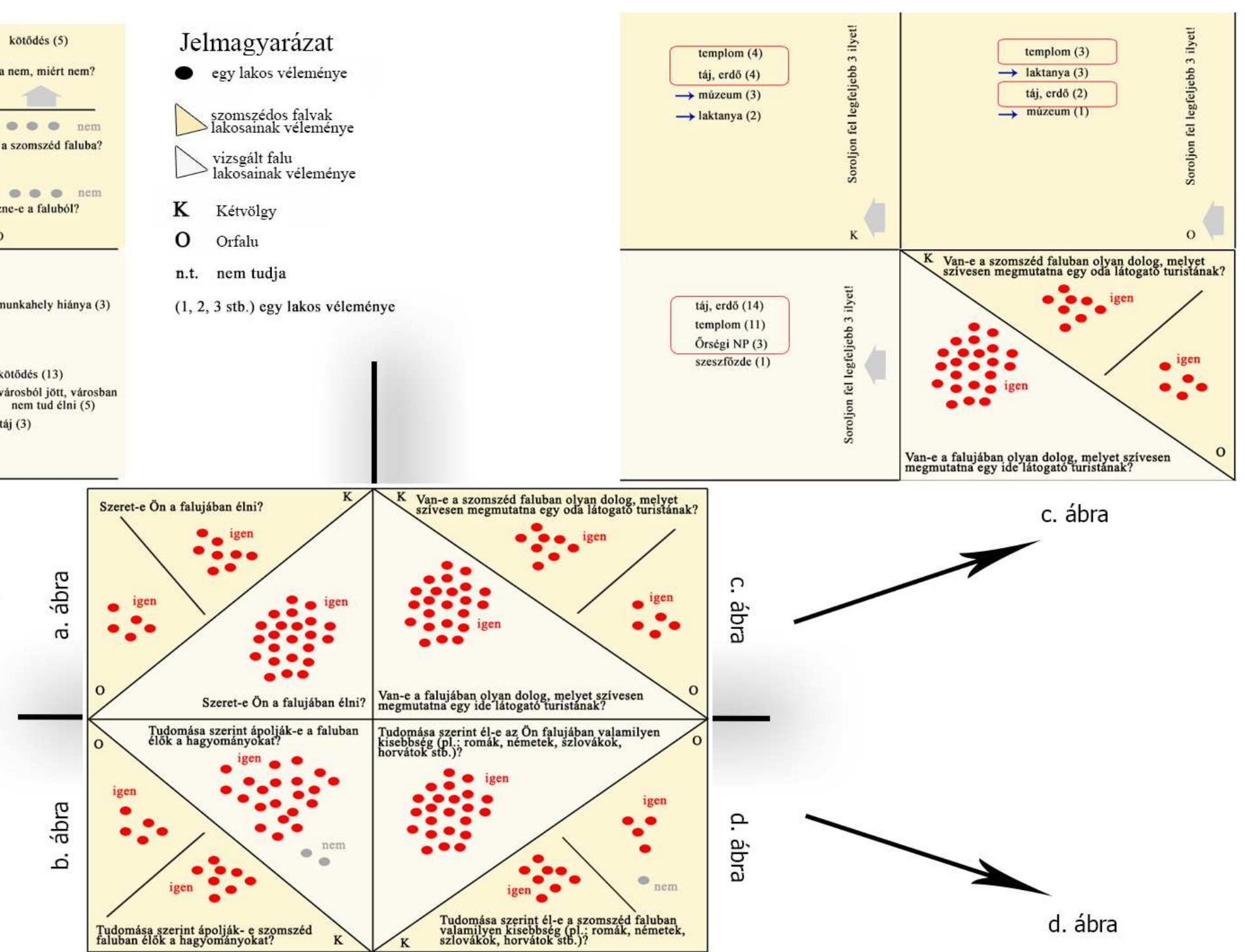

b. ábra

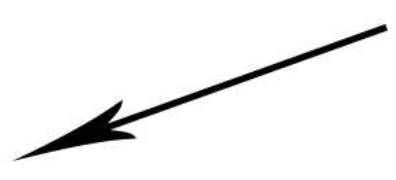

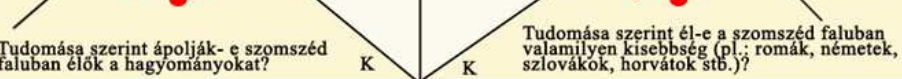
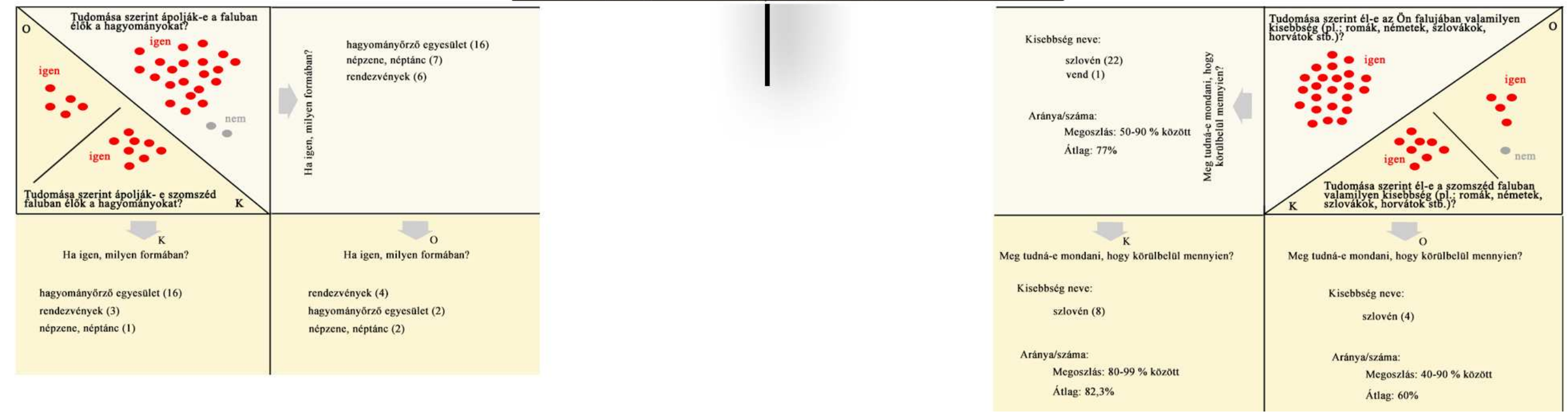

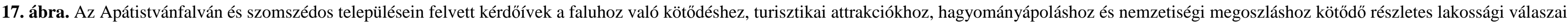
Forrâs: saját szerkesztés 


\section{5. sz. melléklet: Interjúvázlat}

\section{A POLGÁRMESTER SZEMÉLYÉVEL KAPCSOLATOS KÉRDÉSEK ${ }^{25}$ :}

- A településre való-e, vagy beköltözött a faluba?

- Mi az eredeti foglalkozása, volt-e korábban kapcsolata az önkormányzatisággal?

- Mióta polgármester? Amennyiben több cikluson keresztül, úgy folyamatosan tölti-e be a tisztséget?

- Milyen indíttatásból jelöltette magát?

\section{A LAKOSSÁG ÉS A POLGÁRMESTER KAPCSOLATA, ETNIKAI ÖSSZETÉTEL,}

- Mit tapasztal, milyen a polgármester kapcsolata a lakossággal? Megvan-e mindkét fél részéről az együttmüködési hajlandóság ( $\mathrm{pl}$. a polgármester az önkormányzati döntések elökészítésébe bevonja-e a lakosságot, a lakosok bekapcsolódnak-e a helyi rendezvények elökészítésébe, lebonyolításába stb.)?

- Milyen a település etnikai összetétele? Van-e nemzetiségi jelenlét a faluban? Ha igen, hogyan jellemezné a nemzetiségi lakosokat?

- Vannak-e lakossággal kapcsolatos problémák? Ha igen, milyen jellegüek?

\section{GAZDASÁGI TEVÉKENYSÉGRE ÉS FOGLALKOZTATÁSRA VONATKOZÓ ADATOK:}

- Mi a lakosság fő megélhetési forrása?

- Kik a települési fő foglalkoztatók? Jellemzö-e a falura, hogy a lakosai nem helyben találnak munkaalkalmat, hanem a közeli városban dolgoznak?

- Vannak-e helyi vállalkozók? Milyen tevékenységet folytatnak? Milyen a faluval való kapcsolatuk?

\section{A TELEPÜLÉS MARKETINGTEVÉKENYSÉGE:}

- Szerepelt-e a falu az elmúlt években nyomtatott és/vagy elektronikus médiában? Ha igen, milyen témában történt a hírközlés?

- Rendelkezik-e a falu saját médiával?

- Vannak-e a településnek testvérvárosi kapcsolatai?

- Együttmüködik-e a falu a környező településekkel? Ha igen, milyen formában?

\section{PÁLYÁZATI TEVÉKENYSÉG, A TELEPÜLÉS JÖVEDELMI HELYZETE:}

- Milyen bevételi forrásai vannak a falunak?

- Milyen témájú projektek, pályázatok valósultak meg a településen?

- Vannak-e ismeretei a településvezetés rövid távú, középtávú, hosszú távú terveiről?

- Van-e ismerete az önkormányzat jövedelmi helyzetére, müködési nehézségeire vonatkozóan? Mit tesz a település vezetése a falut érintő gazdasági problémák ellen?

\section{CIVIL SZERVEZETEK:}

- Müködik-e a faluban civil szervezet? Ha igen, hogyan jellemezné azt? Mutassa be a tevékenységét (rendezvények, fellépések, hagyományápolás stb.)!

\footnotetext{
25 A helyi elittel folytatott interjúk során a polgármesterek személyére vonatkozó kérdések nem szerepeltek. Ellenben a velük (pl. óvodapedagógus, borász szakember, civil szervezet tagja, stb.) folytatott interjúk során a személyükhöz szorosan kapcsolódó kérdések (pl. civil szervezetek, közlekedési kapcsolatok, lakásépítés stb.) minden esetben nagyobb súllyal kerültek megkérdezésre, mint a többi interjúalanynál.
} 


\section{INFRASTRUKTURÁLIS ELLÁTOTTSÁG, LAKÁSÉPÍTÉSI ADATOK:}

- Milyen a falu vonalas infrastruktúra ellátottsága (közút, víz-, gáz-, csatornahálózatba bekapcsolt lakások aránya)?

- Milyenek a falu közlekedési kapcsolatai? Hogyan jellemezné a település tömegközlekedési helyzetét?

- Épült-e az utóbbi években új lakás/épület a településen? Milyen számban, milyen beruházási formában, milyen típusú hasznosításra? Hogyan jellemezné az újonnan épült lakásokat/épületeket?

\section{INTÉZMÉNYI ELLÁTOTTSÁG:}

- Hogyan jellemezné a település intézményi ellátottságát?

- Egyedül müködtetik az intézményeket vagy társulásos formában? Ha egyedül/ha társulásos formában, mi annak az oka?

\section{A TERMÉSZETI KÖRNYEZET SAJÁTOSSÁGAI:}

- Rendelkezik e falu természeti, vagy épített örökséggel? Ha igen, a benne rejlő lehetőségeket kiaknázza-e? Milyen formában?

- Fordít-e gondot a település vezetése a falu természeti környezetének megóvására? Miben nyilvánul ez meg?

- A településnek földrajzi elhelyezkedéséböl származik-e bármilyen előnye, hátránya (határmenti helyzet, nagyváros közelsége, Balaton közeli fekvés, stb.)?

- Hol helyezi el a falut fejlettség szempontjából a környező települések között (a falu fejlettebb-e, mint a környezö települések)? Mire alapozza megállapítását?

\section{A VIZSGÁLATBA VONT APRÓFALU HELYI ELITJÉNEK JÖVÖKÉPE ÉS SIKERFOGALMA:}

- Ha minden feltétel adott lenne, mit tenne a település sikerért?

- Milyennek látja a falu jövőjét (fejlődés, stagnálás, vagy hanyatlás prognosztizálható)?

- Milyen tényezőknek köszönhető egy falu fejlődése? Hogyan adná meg a sikeres aprófalu fogalmát? 


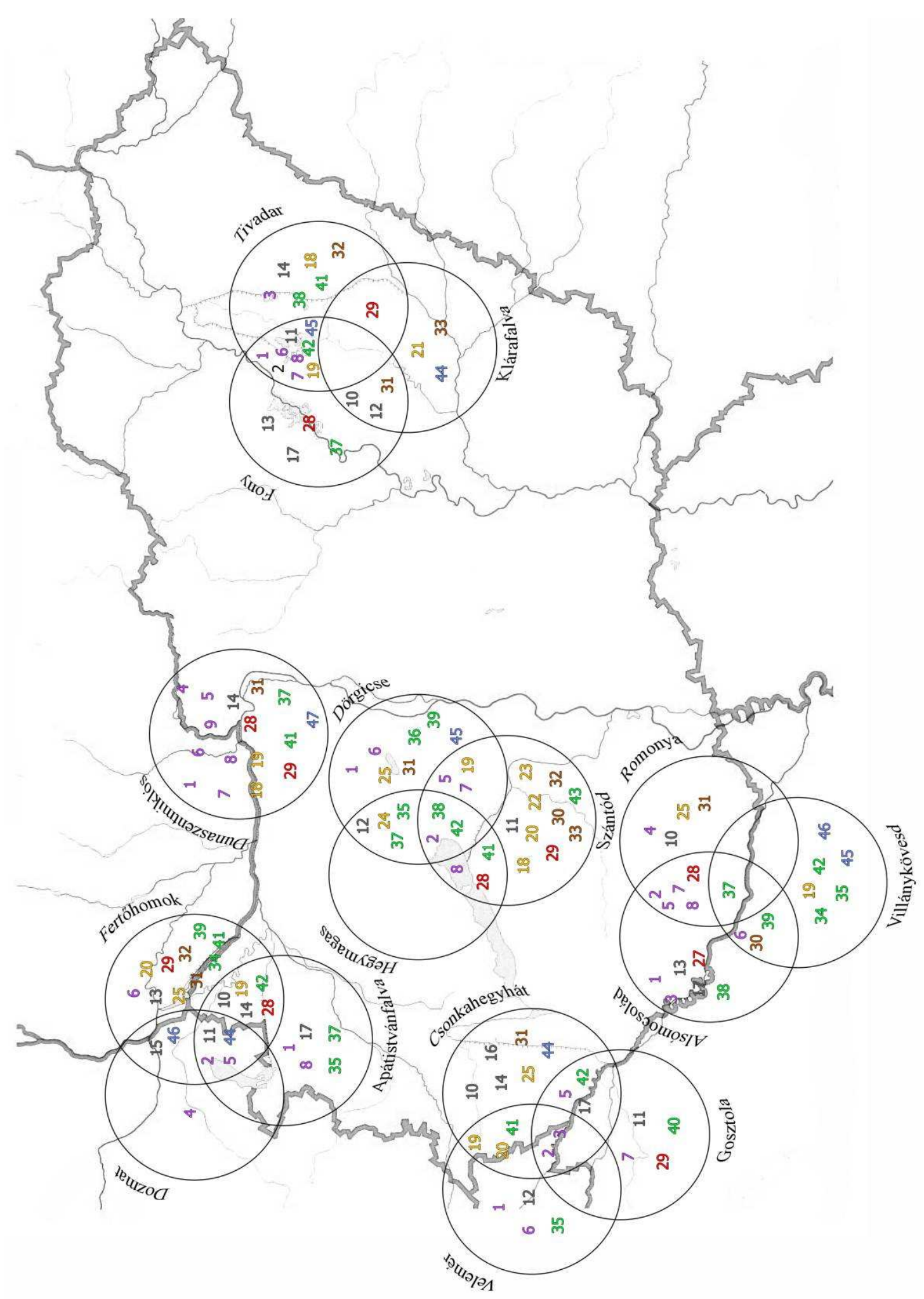

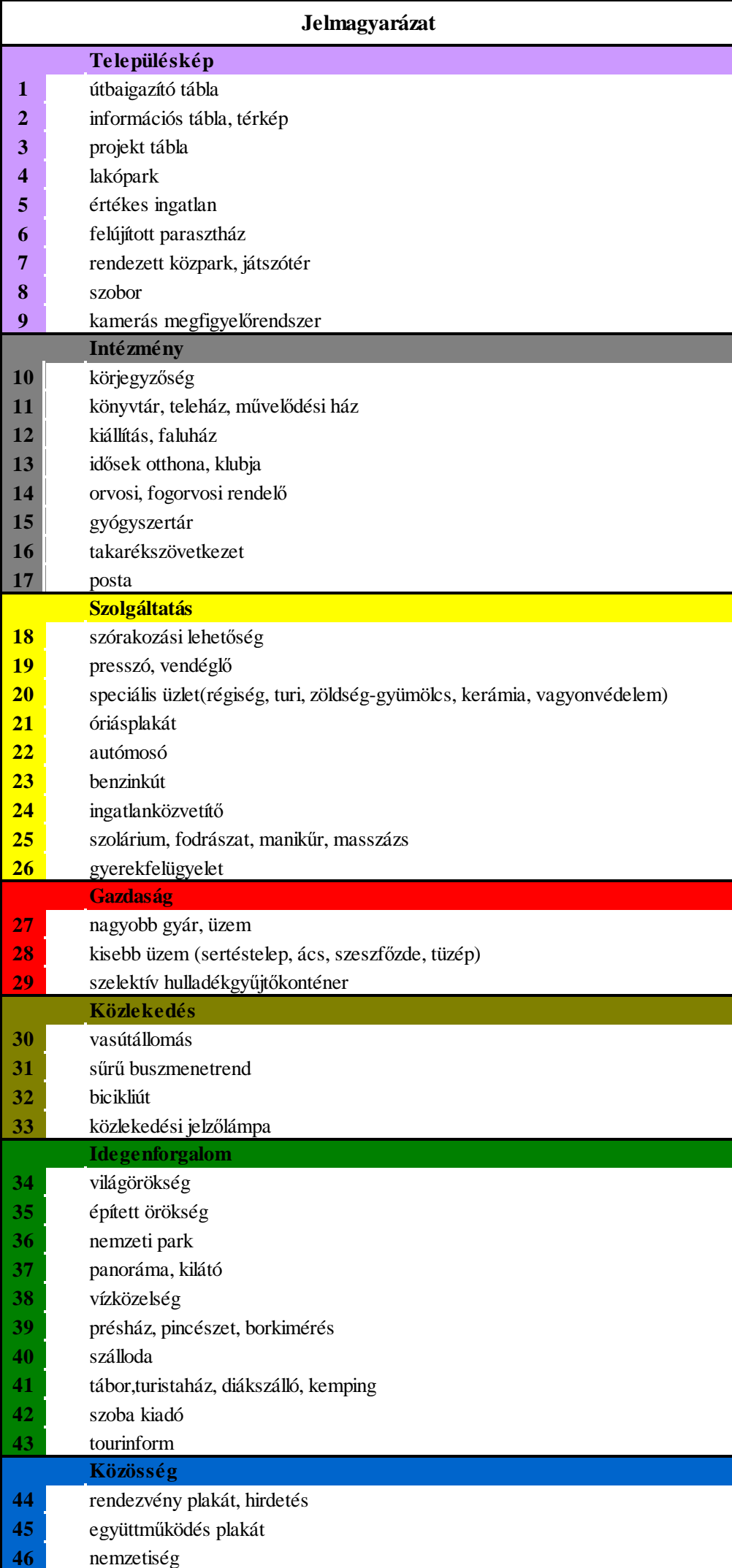

18. ábra. A terepen készített fényképeken fellelhető objektumok, köztük a sikerességi tényezők néhány manifesztációja (Forrás: saját szerkesztés) 


\begin{tabular}{|c|c|c|c|c|c|c|c|c|}
\hline & $\begin{array}{c}\text { Szakirodalmi } \\
\text { sikerességi tényezők }\end{array}$ & Aprófalvak statisztikája & $\begin{array}{l}\text { Összes falu } \\
\text { statiszztikája }\end{array}$ & $\begin{array}{c}\text { Lakossági } \\
\text { vélemények }\end{array}$ & $\begin{array}{c}\text { Környezén } \\
\text { telepuplések } \\
\text { statisztikája }\end{array}$ & Interjúk & \begin{tabular}{l|l} 
S & Fotódokumentáció
\end{tabular} & $\begin{array}{c}\text { Épületállomány } \\
\text { felmérés }\end{array}$ \\
\hline Alsómocsolád & $\begin{array}{l}\text { körjiegyzősségi központ, } \\
\text { ipari funkció }\end{array}$ & & & & & & $\begin{array}{c}\text { rendezett } \\
\text { településkép }\end{array}$ & \\
\hline Apátistvánfalva & $\begin{array}{l}\text { határmentit, szlovén, } \\
\text { körijegyzósesi központ }\end{array}$ & szlovén & & \begin{tabular}{|c|} 
szolgaíltatások helyben, \\
szlovén (hagyomany- \\
apolás)
\end{tabular} & & & & \\
\hline Csonkahegyhát & körjegyzőségi központ & 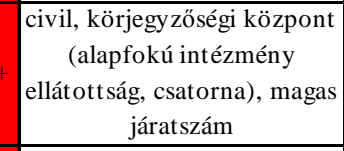 & & & & $\begin{array}{c}\begin{array}{c}\text { konfliktusmentesség, } \\
\text { több ciklust kitöltö } \\
\text { polgármester }\end{array} \\
\end{array}$ & $\begin{array}{l}\text { ellátottsáa, szolgálta- } \\
\text { tások }\end{array}$ & \\
\hline Dörgicse & \begin{tabular}{|c|}
$\begin{array}{c}\text { dezurbán, épített örökség, } \\
\text { bortermelés }\end{array}$ \\
\end{tabular} & épített örökség, csatorna & épített örökség, csatorna & & \begin{tabular}{|l|} 
Környezzỏ telepuilések \\
összfejeltet tsége magasas
\end{tabular} & & $\begin{array}{l}\text { rendezentt telepilliss-s } \\
\text { kép, szolgaltatatasok, } \\
\text { turizmus }\end{array}$ & $\begin{array}{l}\text { épületéállomány } \\
\text { állagmegóvás }\end{array}$ \\
\hline Dozmat & szuburbán, határmenti & $\begin{array}{l}\text { szuburbán (lakópark), } \\
\text { jó közlekedési helyzet }\end{array}$ & \begin{tabular}{|l|} 
szububrbán (lakópark), \\
jó közlekedési helyzet \\
\end{tabular} & & 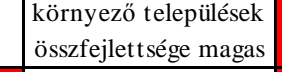 & \begin{tabular}{c|}
$\begin{array}{c}\text { szuburbán, } \\
\text { konfliktusmentesség }\end{array}$ \\
\end{tabular} & & építkezések \\
\hline $\begin{array}{l}\text { Dunaszent- } \\
\text { miklós }\end{array}$ & határmenti, német & $\begin{array}{l}\text { határmenti (vándorlási } \\
\text { nyereseség), német, } \\
\text { vendégéjszaka, gáz, } \\
\text { csatorna, nincs seseglyezett, } \\
\text { jó közlekedési helyzet }\end{array}$ & \begin{tabular}{|c|} 
határmenti (vándorlási \\
nyereseśg), német, \\
vendégéjszaka, gáz, \\
csatorna, nincs \\
segéleyezett, jó \\
közlekedési helyzet \\
\end{tabular} & $\begin{array}{c}\text { közössség, természet, } \\
\text { német (hagyomány- } \\
\text { ápolás), polgármesterrel } \\
\text { aktív kapcsolat }\end{array}$ & \begin{tabular}{|l} 
Környezzö telepiulísek \\
összfejeltstsege magas
\end{tabular} & $\begin{array}{c}\text { több ciklust kitöttố } \\
\text { polgármester }\end{array}$ & $\begin{array}{l}\text { rendezett telepilles- } \\
\text { kép, szelektíí } \\
\text { hulladékgyuuités }\end{array}$ & $\begin{array}{l}\text { épuiletállomány } \\
\text { állagmegóvás, } \\
\text { épitkezések }\end{array}$ \\
\hline Fertöhomok & $\begin{array}{l}\text { határmenti, horvát, jó } \\
\text { közlekedési helyzet }\end{array}$ & $\begin{array}{c}\text { határmenti (vándorlási } \\
\text { nyereség), horvát, gáz, } \\
\text { csatorna, nincs segelyezett }\end{array}$ & $\begin{array}{c}\text { határmenti } \\
\text { (vándorlási nyereség), } \\
\text { horvát, gáz, csatorna, } \\
\text { nincs segélyezett }\end{array}$ & $\begin{array}{l}\text { közzössege, természet, } \\
\text { horvát (hagyomány- } \\
\text { apolás), polgagrmes- } \\
\text { terrel aktiv kapssolat }\end{array}$ & 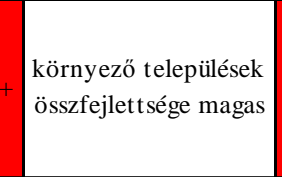 & \begin{tabular}{|c|} 
konfliktusmentesség, \\
több ciklust kitöltő \\
polgármester, \\
pályázatok, \\
rendezvények \\
\end{tabular} & 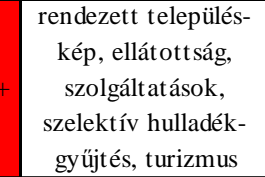 & $\begin{array}{l}\text { épületállomány } \\
\text { állagmegóvás }\end{array}$ \\
\hline Fony & $\begin{array}{c}\text { épített örökség, } \\
\text { körjegyzősési központ }\end{array}$ & & & & & & ellátottság & \\
\hline Gosztola & $\begin{array}{l}\text { dezurbán, kis telepuilésméret, } \\
\text { magas SZJA }\end{array}$ & $\begin{array}{l}\text { kis méret (betelepülés), } \\
\text { civil, iskolázottság, } \\
\text { vendégéjzzzaka, magas SZJA, } \\
\text { nincs segélyezett }\end{array}$ & \begin{tabular}{|c|} 
kis méret \\
(betelepülés), civil, \\
iskolázottság, \\
vendégéjszaka, magas \\
SZJA, nincs segélyezett
\end{tabular} & & & $\begin{array}{c}\text { konfliktusmentesség, } \\
\text { több ciklust kitöltö } \\
\text { polgarmester }\end{array}$ & $\begin{array}{l}\text { szelektív hulladék- } \\
\text { gyǘtés }\end{array}$ & $\begin{array}{l}\text { épuiletéallomány } \\
\text { állagmegóvás }\end{array}$ \\
\hline Hegymagas & erōs közössség, bortermelés & $\begin{array}{l}\text { kulturális rendezzény, } \\
\text { csatorna }\end{array}$ & $\begin{array}{l}\text { kulturális rendezvény, } \\
\text { csatorna }\end{array}$ & közösség, természet & \begin{tabular}{|l|} 
Környezzỏ telepiulések \\
összfejeltet sége magasas
\end{tabular} & $\begin{array}{c}\text { konfliktusmentessség, } \\
\text { palyáazatok, } \\
\text { rendezvenyek }\end{array}$ & turizmus & $\begin{array}{l}\text { épuliutéillomány } \\
\text { allaggegegóvás }\end{array}$ \\
\hline Klárafalva & \begin{tabular}{|l} 
alfölddi kicsi, jó közlekedési \\
helyzet
\end{tabular} & $\begin{array}{l}\text { jó közlekedési helyzet } \\
\text { (magasa járat szám) }\end{array}$ & & & & & & \\
\hline Romonya & $\begin{array}{c}\begin{array}{c}\text { szuburbán, körjegyzőségi } \\
\text { központ }\end{array} \\
\end{array}$ & $\begin{array}{c}\text { szuburbán (lakópark), } \\
\text { körjegyzőségi központ, } \\
\text { magas járat szäm }\end{array}$ & & & & $\begin{array}{l}\text { szuburbán, több } \\
\text { ciklust kitöttö } \\
\text { polgármester }\end{array}$ & & építkezések \\
\hline Szántód & $\begin{array}{l}\text { kivált telepuiles, Balaton, } \\
\text { vendégészaka }\end{array}$ & 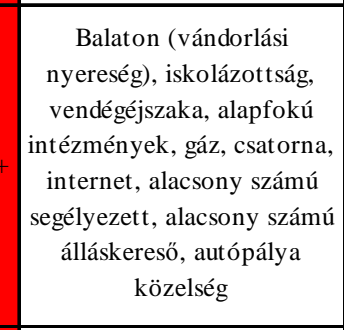 & 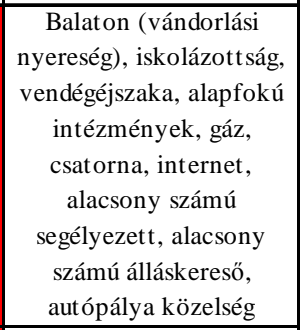 & $\begin{array}{l}\text { ellátottsá, természet, } \\
\text { turizmus }\end{array}$ & \begin{tabular}{|l} 
Koörnyezzō telepiulések \\
összfejelttsége magas
\end{tabular} & $\begin{array}{c}\text { több ciklust kitöltö } \\
\text { polgármester, } \\
\text { turizmus }\end{array}$ & $\begin{array}{l}\text { rendezett telepiulés-s- } \\
\text { kép, szolgáltatások, } \\
\text { szelektív hulladék- } \\
\text { gyüutess, turizmus }\end{array}$ & $\begin{array}{l}\text { épuiletállomány } \\
\text { állagnegóvás }\end{array}$ \\
\hline Tivadar & Tissa, vendegéjszzaka & Tisza, vendeggéjzzaka & & turizmus & & $\begin{array}{l}\text { rendezvények, } \\
\text { turizmus }\end{array}$ & $\begin{array}{l}\text { rendezett telepuileś- } \\
\text { kép }\end{array}$ & \\
\hline Velemér & határmenti, épített örökség & 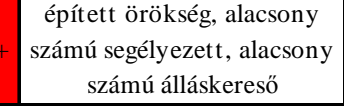 & & & & & & \\
\hline Villánykövesd & $\begin{array}{c}\text { német, épített öröksség, } \\
\text { bortermelés }\end{array}$ & épített örökség & & $\begin{array}{c}\text { német (hagyomány- } \\
\text { apolás) }\end{array}$ & & & turizmus & \\
\hline
\end{tabular}

11. táblázat. A kvantitatív és kvalitatív módszerek alapján lehatárolt sikerességi tényezők köre (Forrás: saját szerkesztés) 
8. sz. melléklet: Fényképgyüjtemény ${ }^{26}$

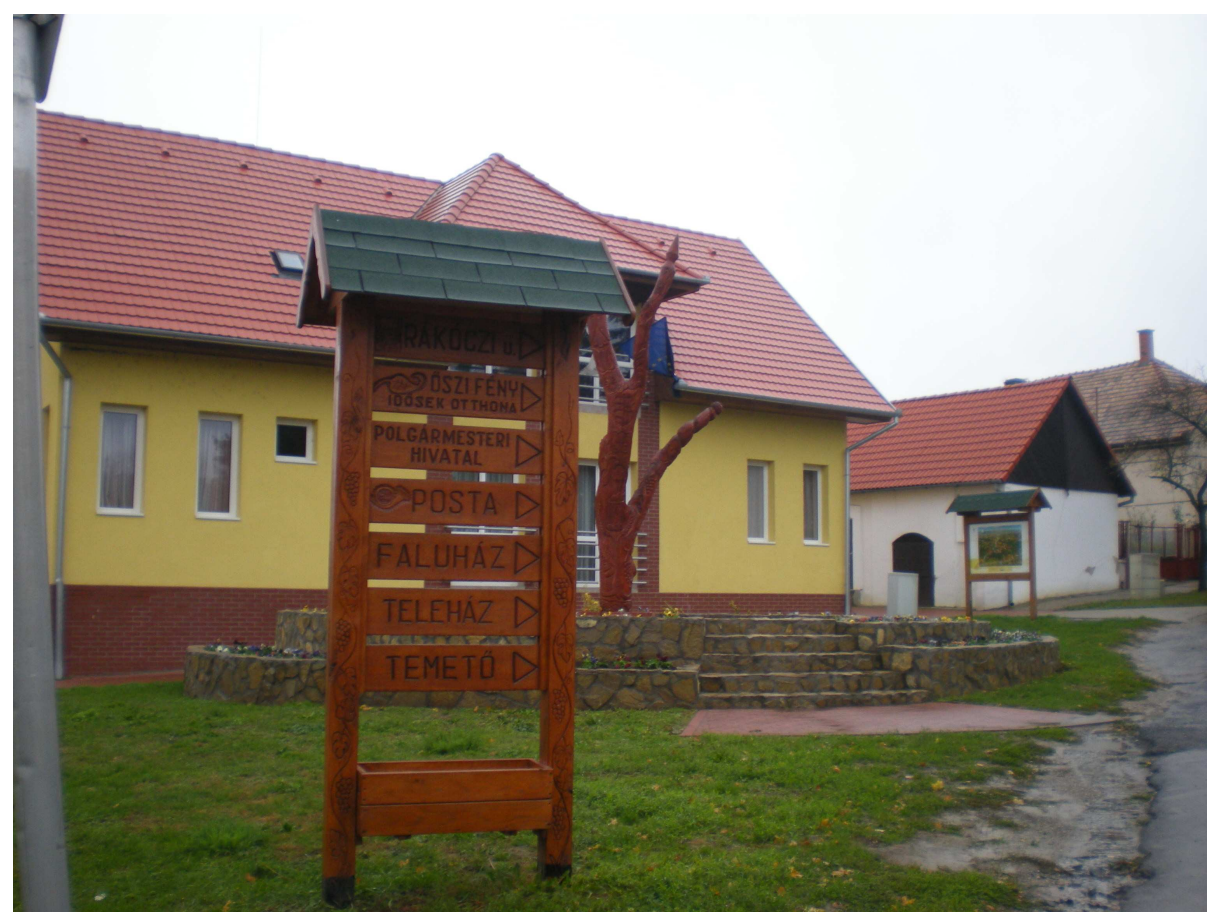

1. kép. Néhány intézmény megnevezése a körjegyzőségi központ Alsómocsolád utcarészletének útbaigazító tábláján

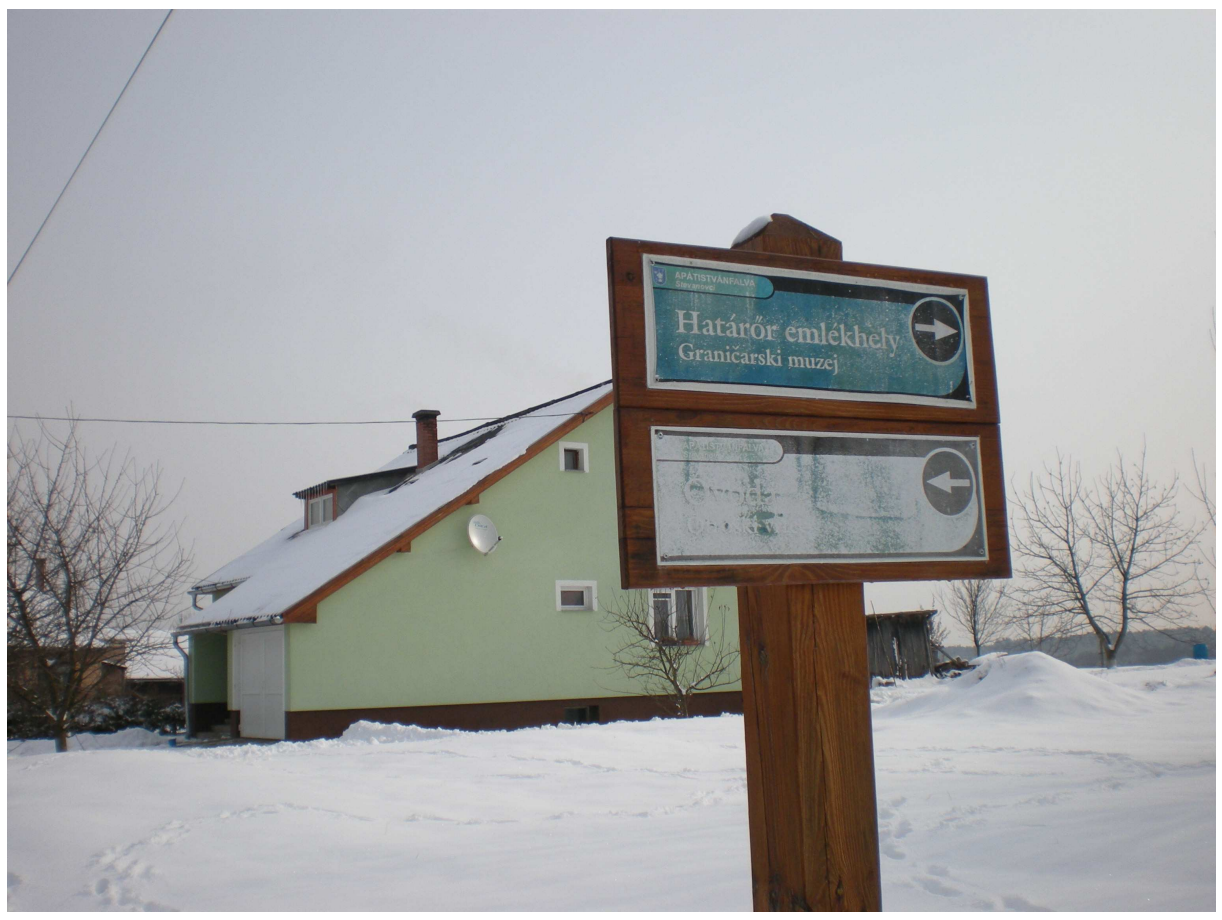

2. kép. Szlovén felirat a határ menti, körjegyzőségi központ Apátistvánfalván

${ }^{26}$ A fényképeket készítette: Dr. Bajmócy Péter, egyetemi docens 


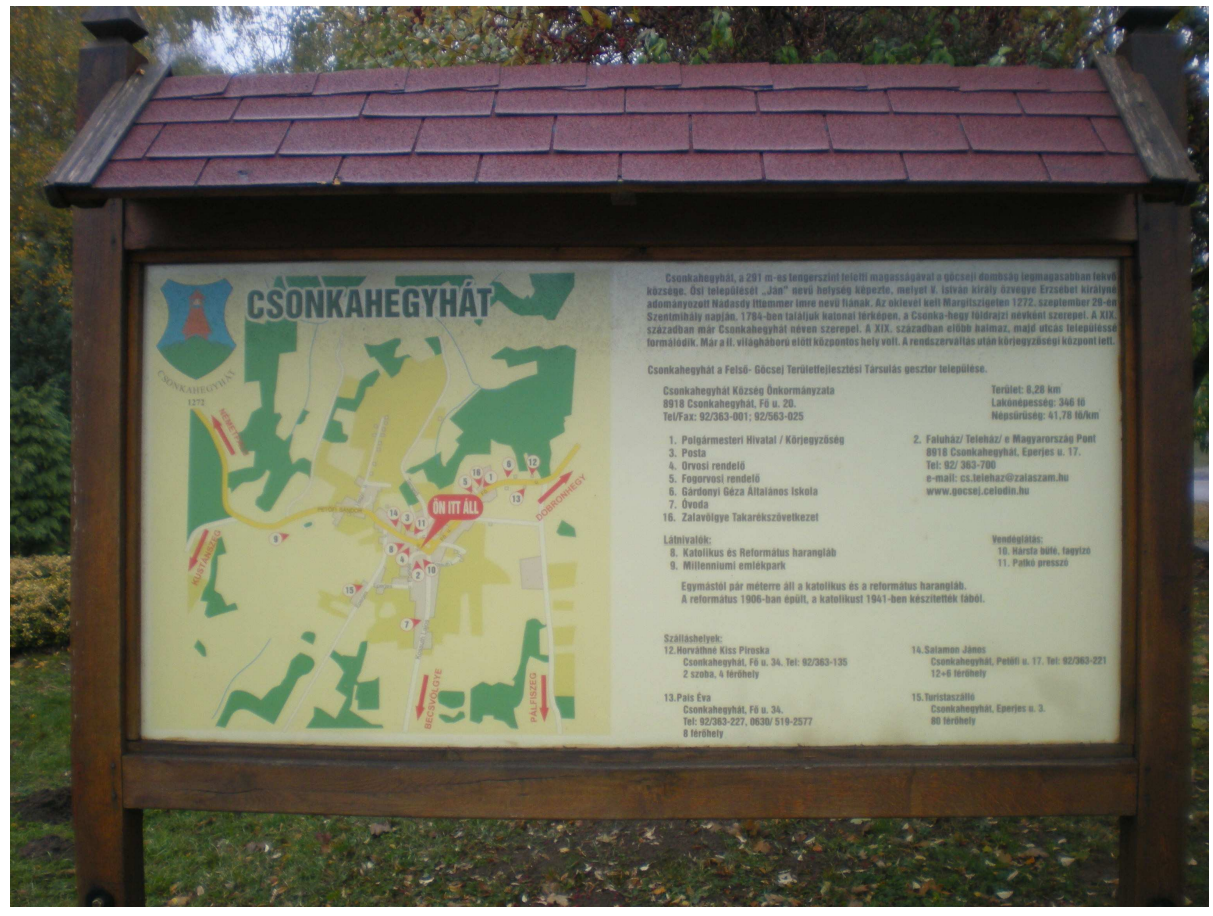

3. kép. Csonkahegyhát - körjegyzőségi központ, több alapfokú intézménnyel

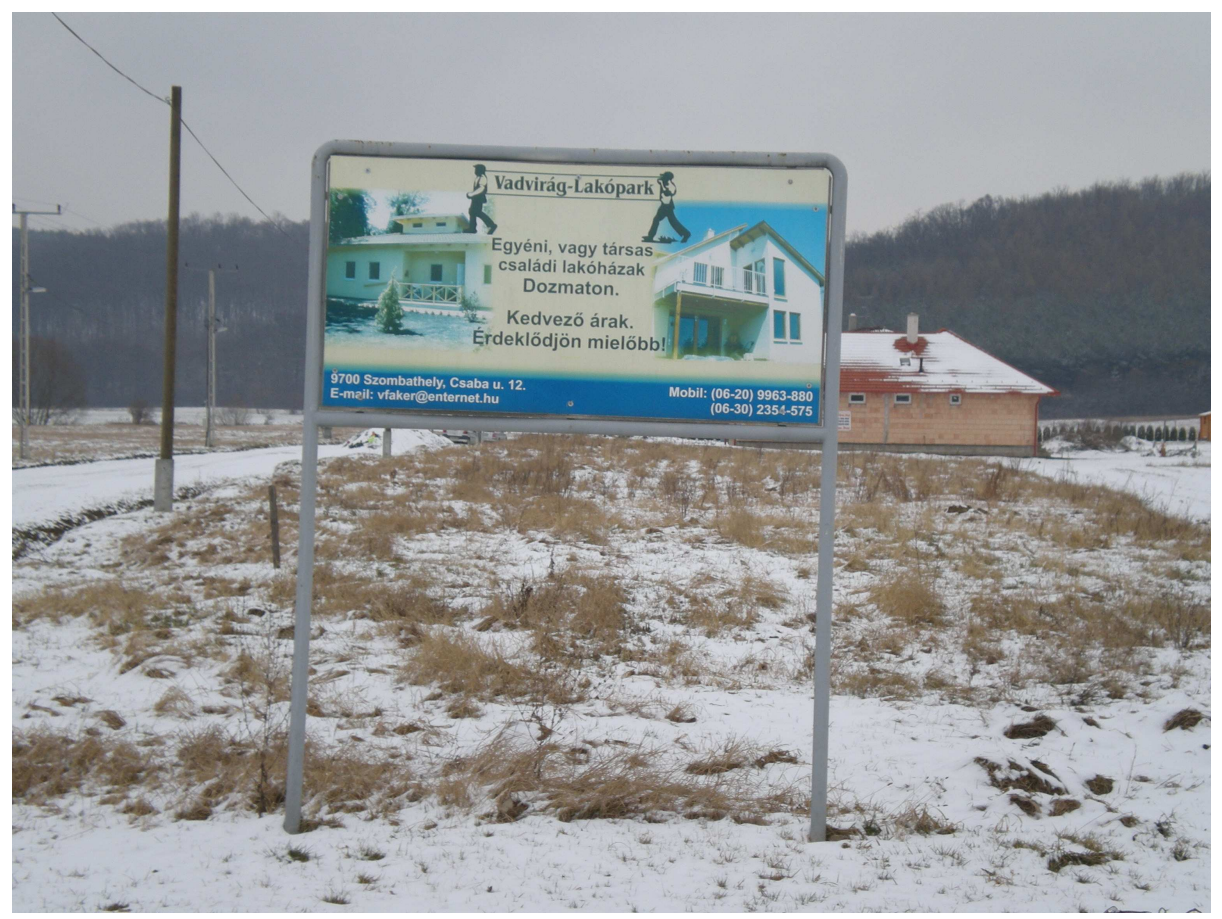

4. kép. Épülő lakópark a határmenti, szuburbán Dozmaton 


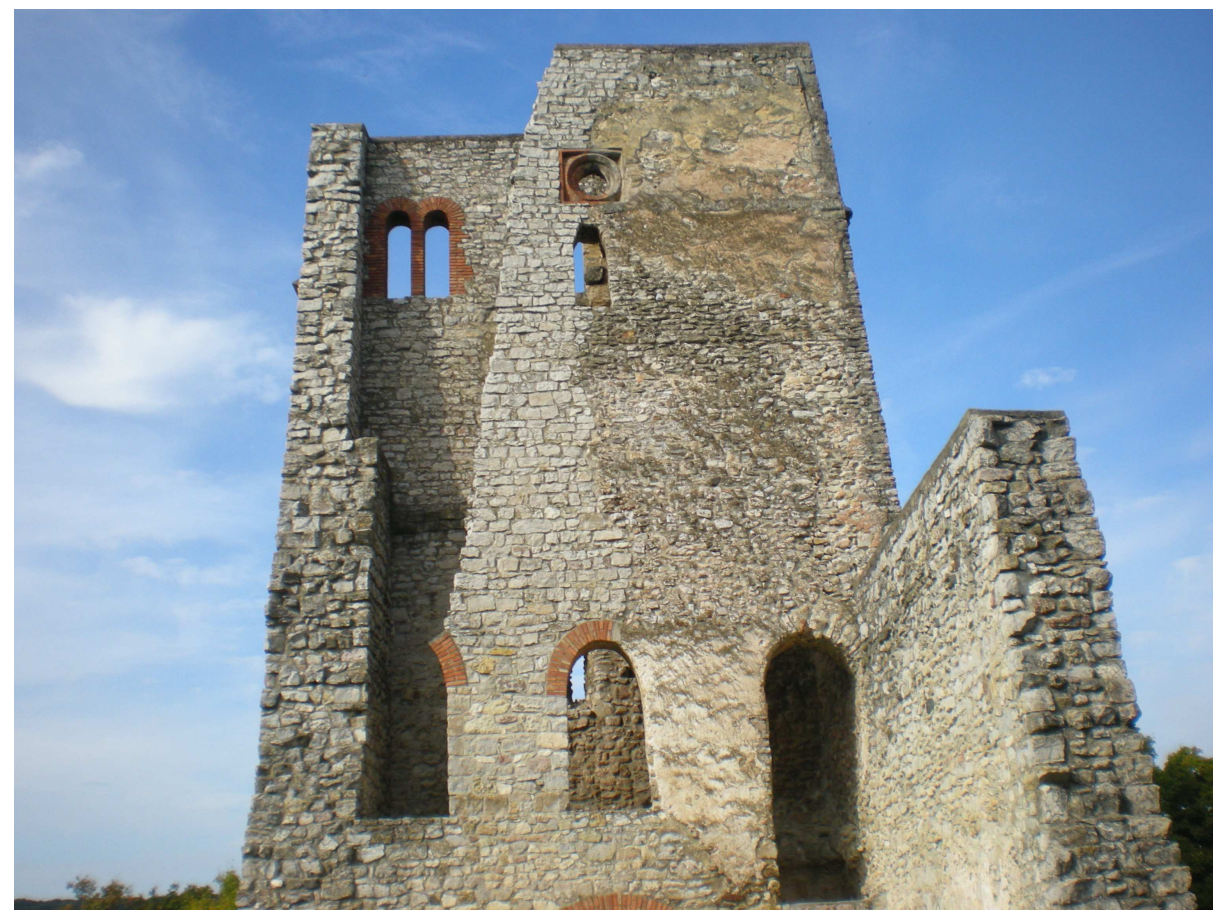

5. kép. XIII. századi romtemplom a bortermelő Dörgicsén

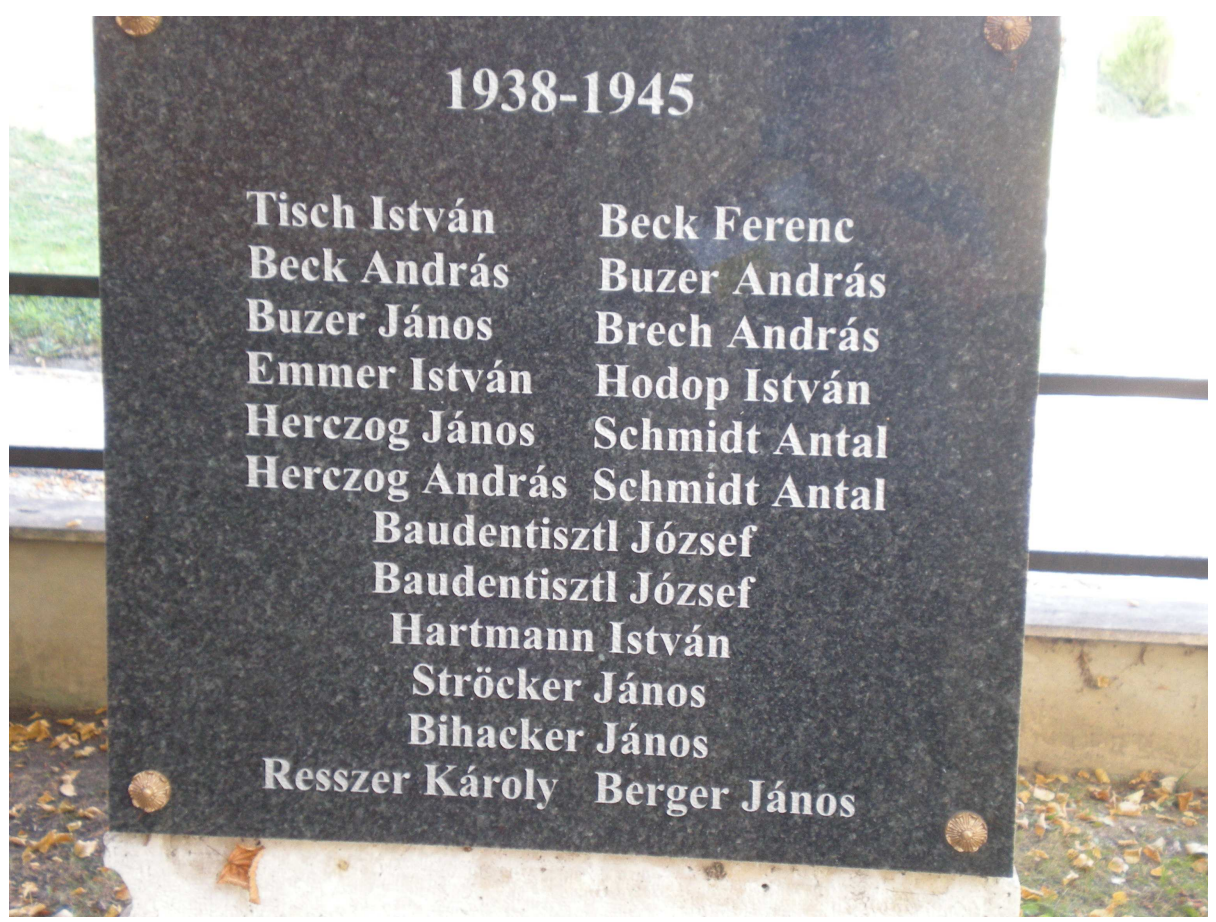

6. kép. Dunaszentmiklós II. világháborús német nemzetiségű áldozatainak emléktáblája 


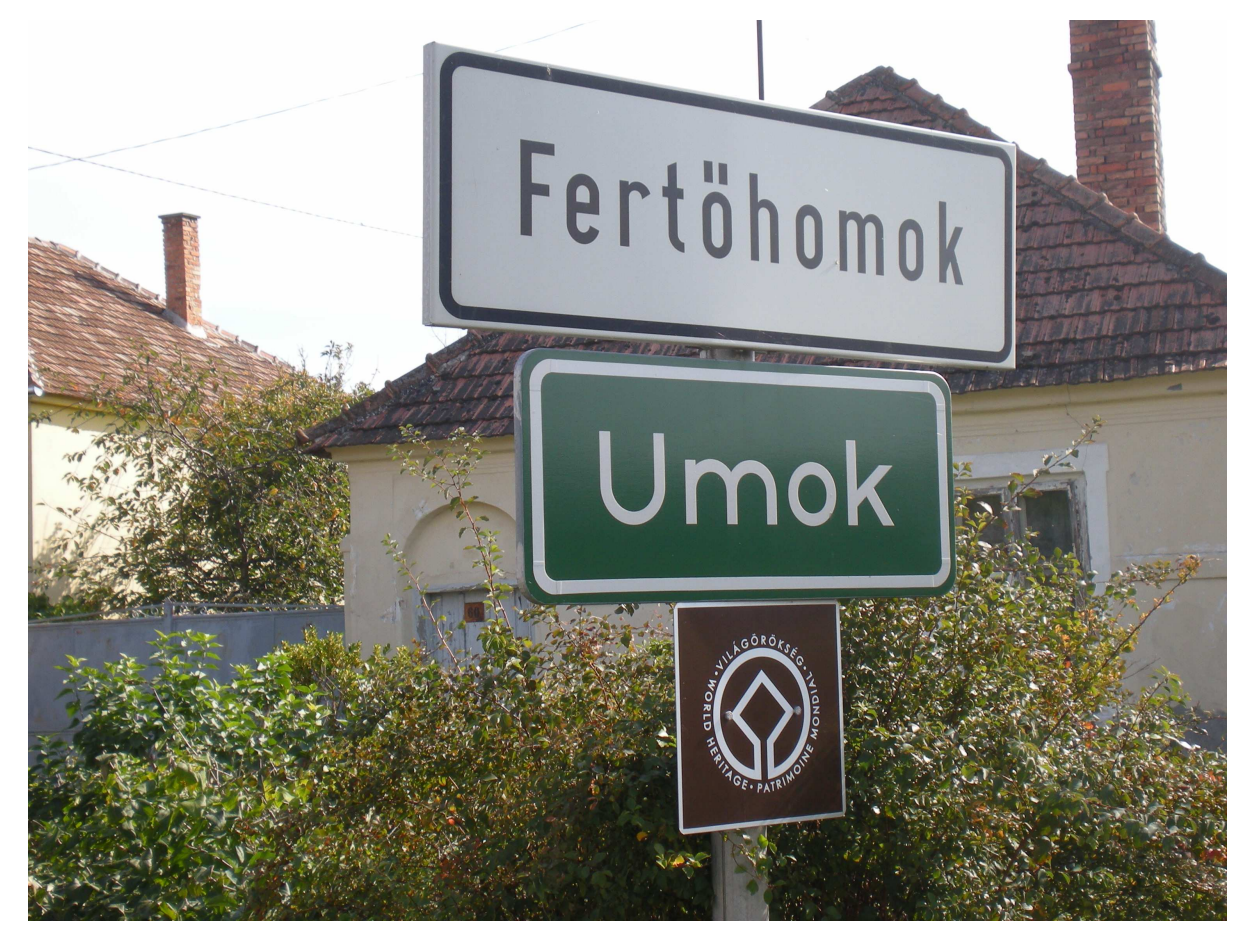

7. kép. A Fertő-Hanság Nemzeti Park világörökségi helyszínének, a horvát nemzetiségü Fertőhomoknak a helységnévtáblája

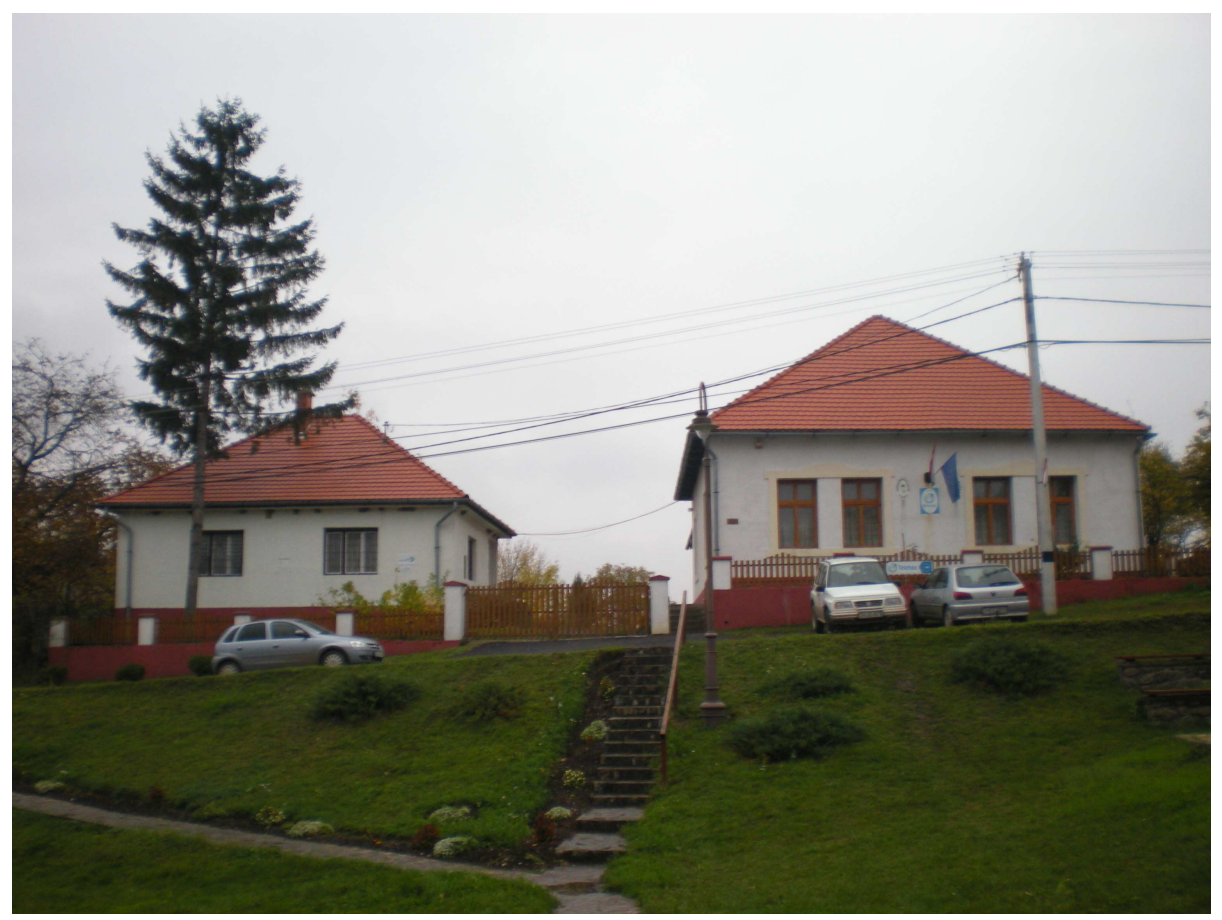

8. kép. Az egyik legkevésbé sikeres aprófalu, Fony körjegyzőségi központjának székhelye 


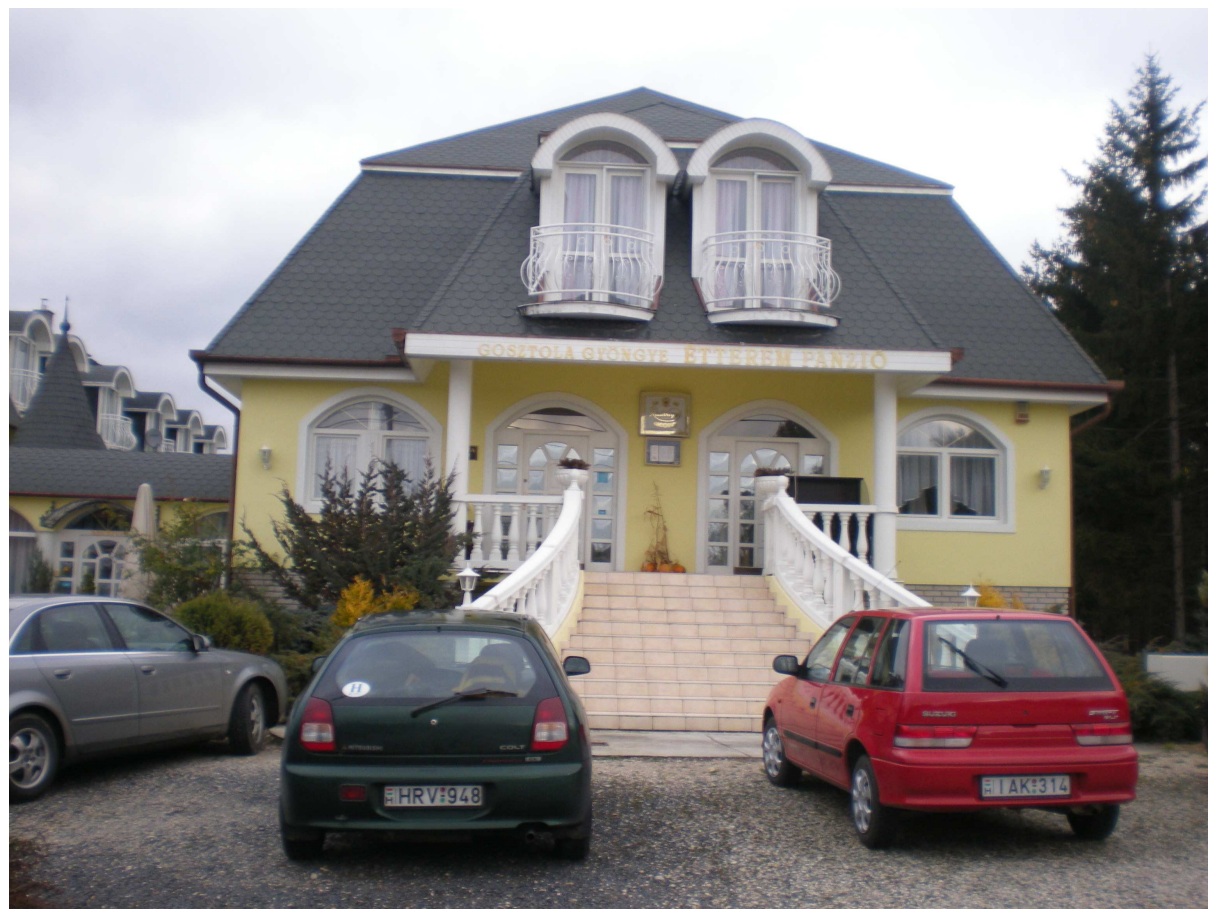

9. kép. A legkisebb lakosságszámú vizsgálatba vont település - Gosztola - magas vendégéjszaka számot generáló hotele

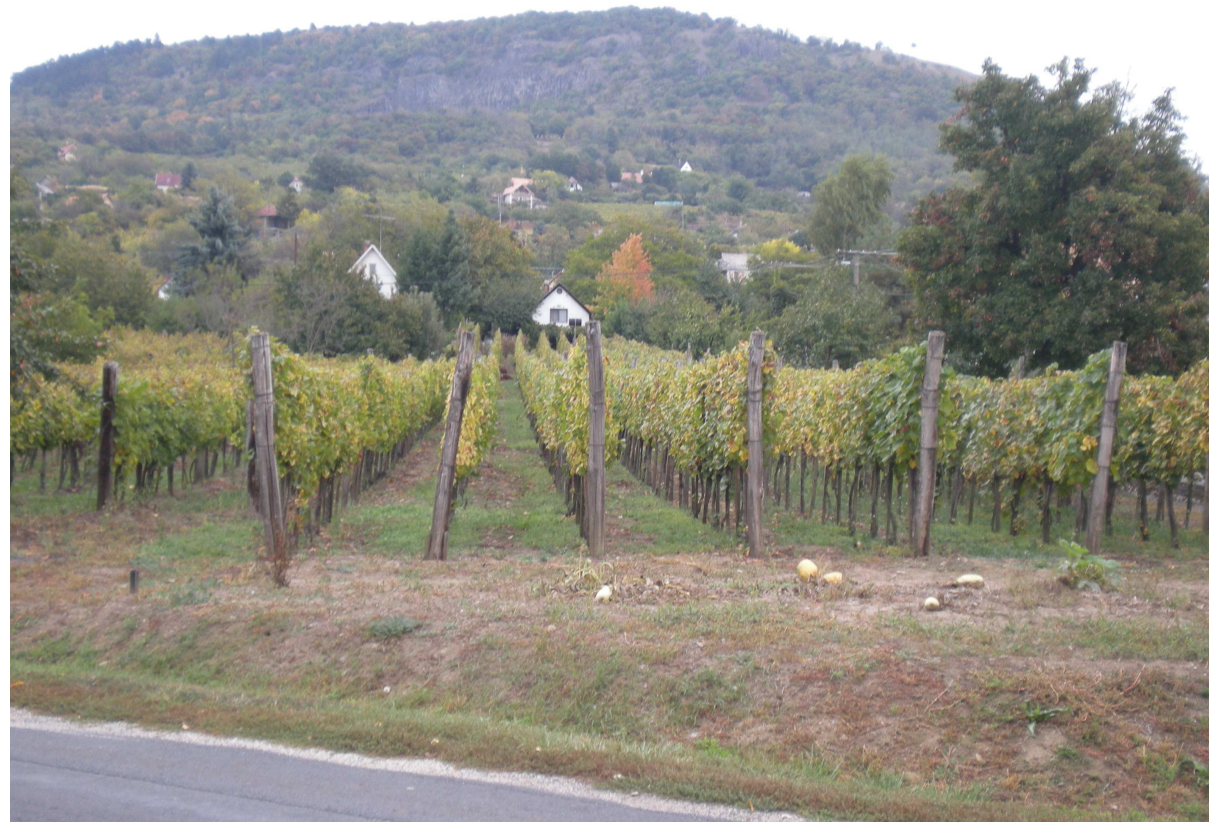

10. kép. A bortermelő Hegymagas szőlői. A falu közösségi összefogása a település sikerességéhez nagyban hozzájárul 


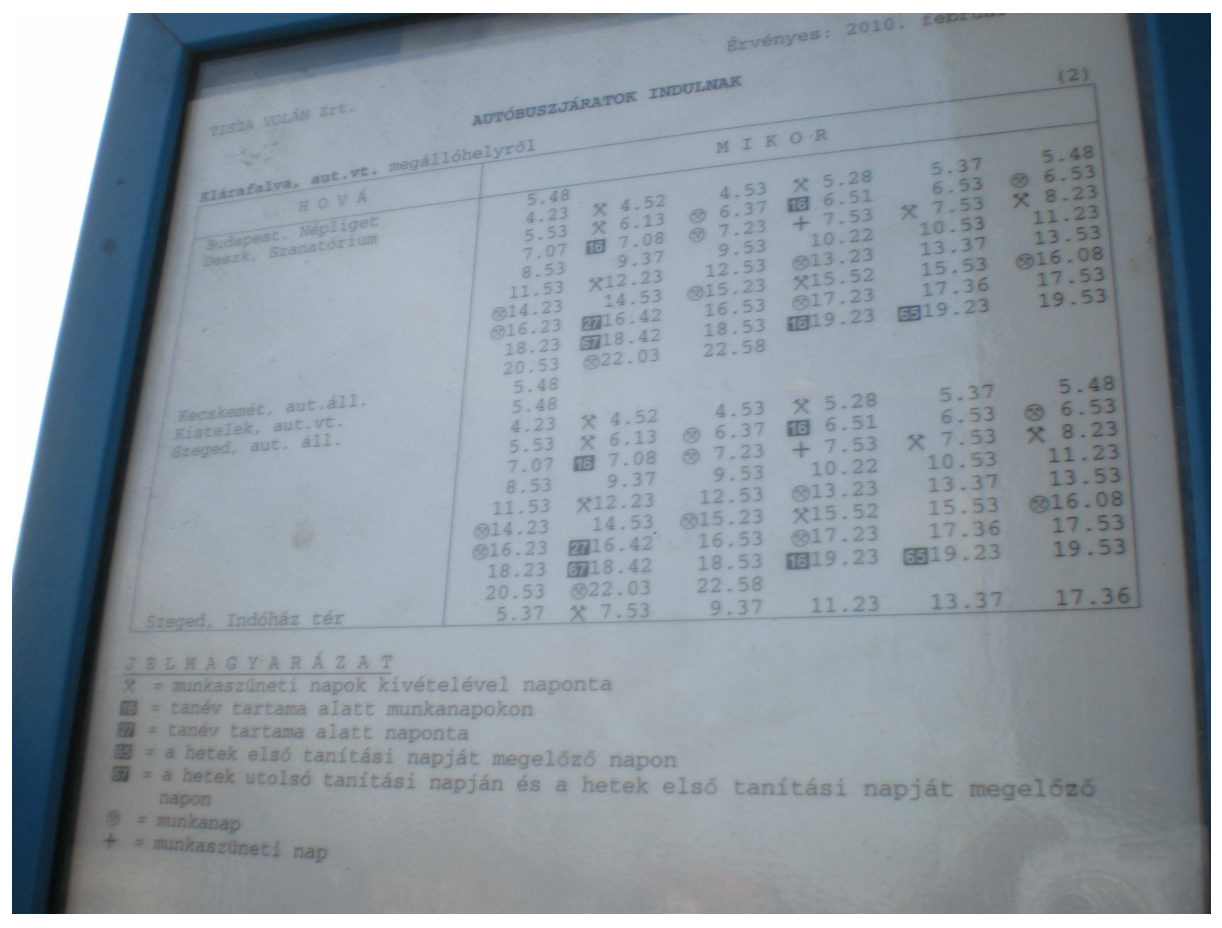

11. kép. A Szeged közeli Klárafalva meglehetősen magas tömegközlekedési viszonylatszámot mutató buszmenetrendje

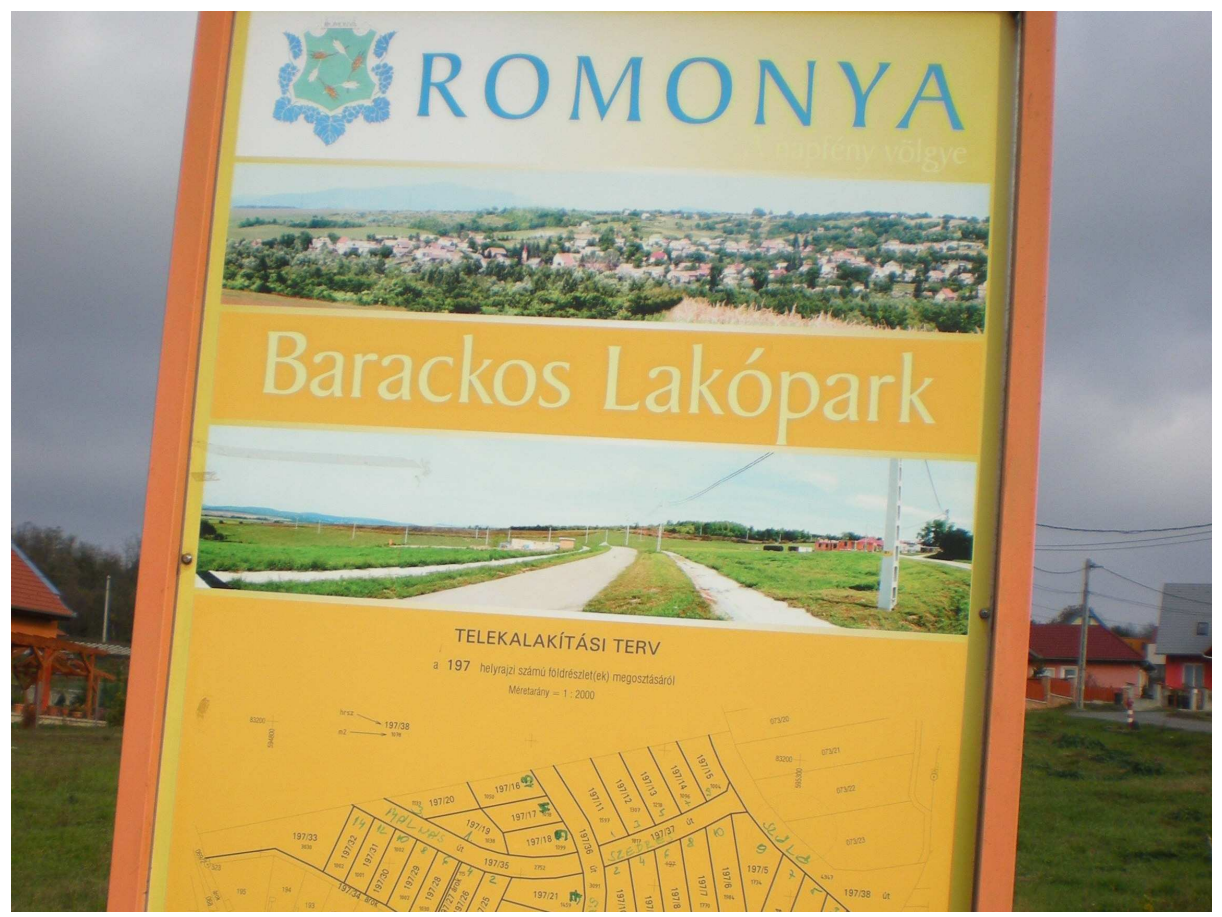

12. kép. A szuburbán Romonya újonnan épített lakóparkjának telekfelosztását mutató információs táblája 


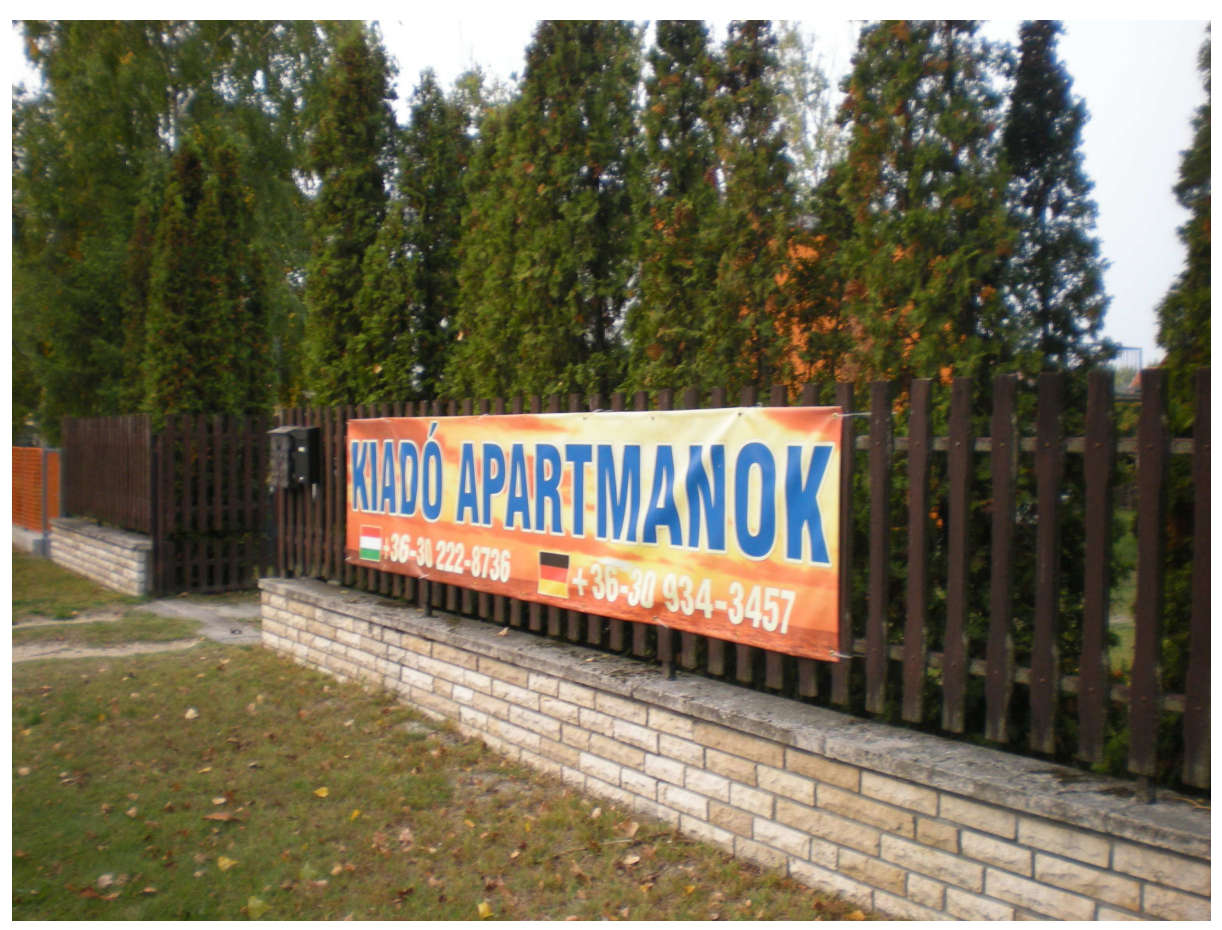

13. kép. A jó ellátottsággal rendelkező Szántód a Balaton partján nem csak a hazai utazóközönséget célozza meg

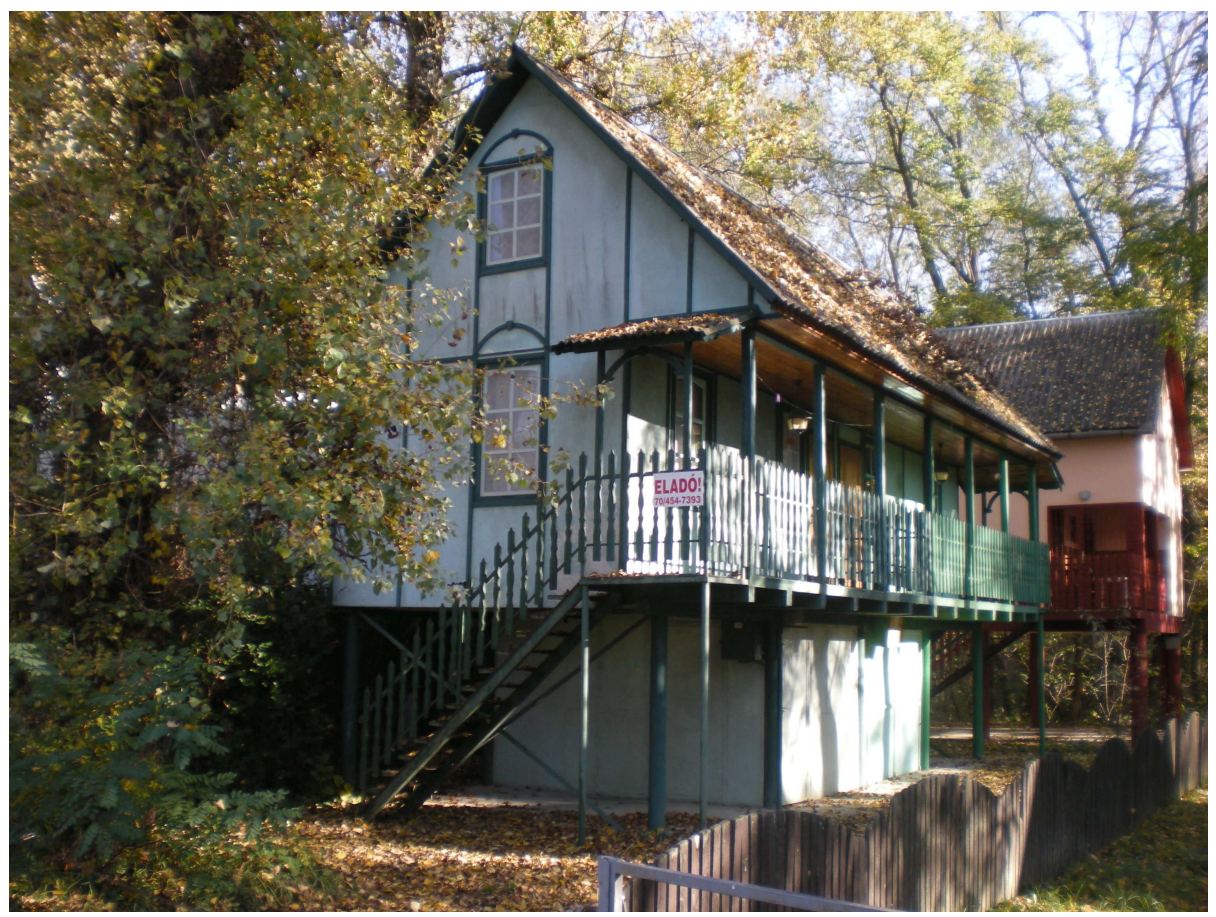

14. kép. A Tisza-parti Tivadar tipikus part menti utcarészlete Beregben 


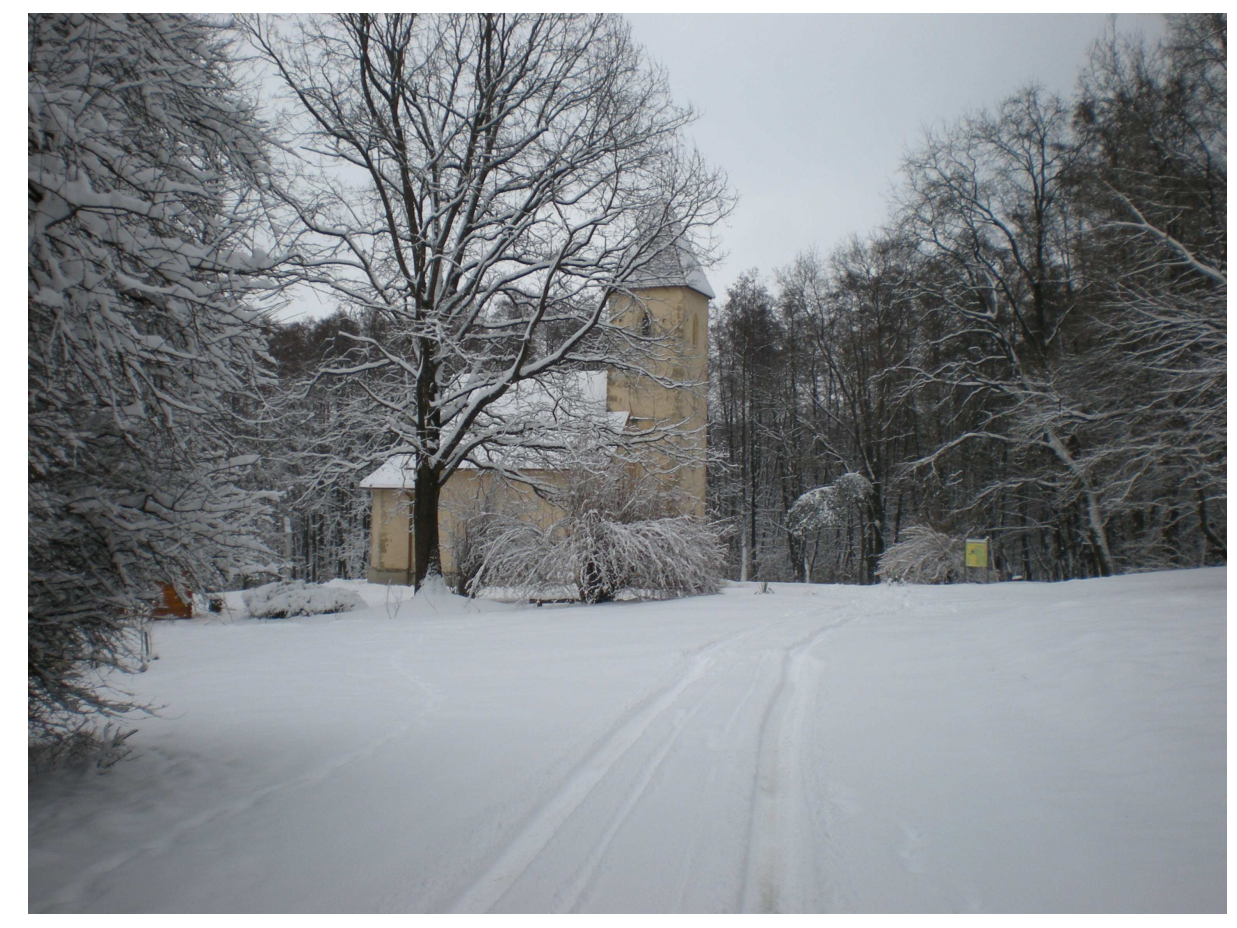

15. kép. A határ menti Velemér Árpád kori temploma

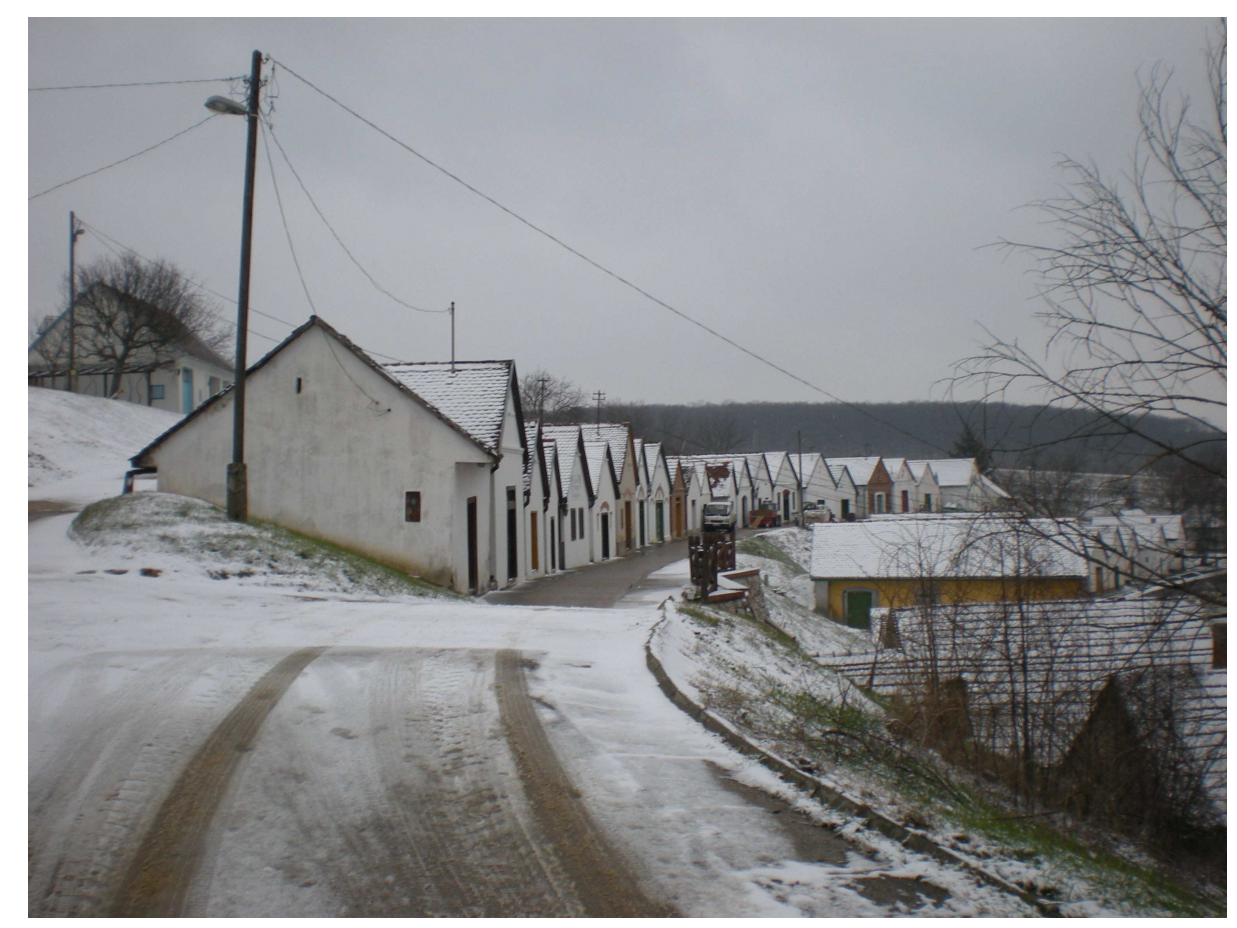

16. kép. A német nemzetiségü Villánykövesd pincesora 


\section{9. sz. melléklet: Az aprófalvak egységnormált fejlettségi értékei}

\begin{tabular}{|c|c|c|c|c|c|c|c|c|c|c|c|}
\hline Településnév & $\begin{array}{l}\text { Népesség- } \\
\text { szám, } 2010\end{array}$ & $\begin{array}{l}\text { Népes- } \\
\text { ség }\end{array}$ & $\begin{array}{l}\text { Társa- } \\
\text { dalom }\end{array}$ & $\begin{array}{l}\text { Társa- } \\
\text { dalom } \\
\text { (2011) }\end{array}$ & Ellátottság & Gazdaság & $\begin{array}{l}\text { Közle- } \\
\text { kedés }\end{array}$ & $\begin{array}{l}\text { Idegen- } \\
\text { forgalom }\end{array}$ & $\begin{array}{l}\text { Összfej- } \\
\text { lettség }\end{array}$ & $\begin{array}{c}\begin{array}{c}\text { H. Apró- } \\
\text { falu }\end{array} \\
\end{array}$ & $\begin{array}{c}\text { H. Fal- } \\
\text { vak }\end{array}$ \\
\hline Abaújalpár & 86 & 155,98 & 15,77 & 36,81 & 102,64 & 123,13 & 162,95 & 36,98 & 597,45 & 1022 & 2882 \\
\hline Abaújlak & 127 & 237,50 & 57,18 & 59,81 & 18,56 & 222,20 & 139,91 & 120,00 & 795,35 & 526 & 2135 \\
\hline Abaújszolnok & 198 & 273,12 & 21,90 & 26,00 & 24,80 & 90,87 & 135,43 & \begin{tabular}{l|l|}
0,00 \\
\end{tabular} & 546,11 & 1062 & 2924 \\
\hline Abaújvár & 234 & 182,17 & 49,83 & 56,10 & 212,79 & 133,79 & 147,58 & 46,85 & 773,01 & 603 & 2291 \\
\hline Abod & 232 & 168,83 & 51,16 & 80,53 & 83,06 & 179,10 & 160,75 & 31,13 & 674,03 & 892 & 2734 \\
\hline Acsalag & 494 & 198,44 & 39,30 & 39,77 & 135,44 & 250,02 & 180,03 & 14,88 & 818,11 & 438 & 1952 \\
\hline Adorjánháza & 433 & 196,04 & 26,76 & 31,48 & 147,45 & 183,08 & 117,05 & 18,05 & 688,43 & 863 & 2693 \\
\hline Adorjás & 211 & 241,57 & 14,55 & 19,52 & 80,43 & 126,76 & 144,48 & 21,62 & 629,40 & 987 & 2841 \\
\hline Ág & 198 & 220,07 & 2,63 & 13,44 & 103,40 & 95,55 & 159,50 & 12,38 & 593,53 & 1028 & 2888 \\
\hline Aka & 262 & 216,86 & 35,64 & 46,34 & 161,71 & 236,82 & $\begin{array}{ll}163,95 \\
\end{array}$ & 9,35 & 824,33 & 418 & 1900 \\
\hline Alibánfa & 456 & 224,32 & 58,47 & 57,60 & 159,18 & 229,55 & 223,37 & 11,79 & 906,68 & 206 & 1175 \\
\hline Almamellék & 464 & 208,60 & 47,84 & 64,15 & 183,08 & 143,20 & 159,95 & 77,83 & 820,50 & 430 & 1929 \\
\hline Almásháza & 71 & 260,35 & 40,78 & 72,34 & 72,22 & 217,14 & 161,72 & 138,43 & 890,63 & 241 & 1295 \\
\hline Almáskeresztúr & 90 & 191,56 & 12,71 & 43,54 & 93,78 & 140,54 & 172,96 & \begin{tabular}{l|l|}
0,00 \\
\end{tabular} & 611,55 & 1006 & 2866 \\
\hline Alsóbogát & 288 & 205,67 & 42,03 & 55,35 & 125,74 & 182,58 & \begin{tabular}{ll|}
166,62 \\
\end{tabular} & 37,02 & 759,66 & 645 & 2372 \\
\hline Alsódobsza & 329 & 189,92 & 47,54 & 69,35 & 207,67 & 211,25 & 176,37 & 14,90 & 847,65 & 350 & 1704 \\
\hline Alsógagy & 114 & 208,56 & 71,13 & 89,65 & 37,49 & 171,86 & 156,04 & 10,00 & 655,09 & 941 & 2794 \\
\hline Alsómocsolád & 360 & 215,19 & 50,11 & 76,21 & 162,44 & 206,63 & 133,62 & 77,36 & 845,34 & 359 & 1727 \\
\hline Alsórajk & 372 & 185,80 & 28,72 & 36,29 & 126,05 & 245,29 & 187,69 & 10,32 & 783,87 & 577 & 2237 \\
\hline Alsóregmec & 215 & 194,08 & 68,64 & \begin{tabular}{|l|}
102,67 \\
\end{tabular} & 239,06 & 214,91 & 145,01 & 38,37 & 900,06 & 217 & 1225 \\
\hline Alsószenterzsébet & 78 & 171,52 & 46,35 & 30,17 & 109,11 & 290,40 & 162,12 & 38,55 & 818,04 & 439 & 1953 \\
\hline Alsószölnök & 392 & 202,64 & 108,43 & 108,50 & 168,25 & 210,19 & 168,91 & 39,47 & 897,89 & 223 & 1246 \\
\hline Alsószuha & 478 & 211,56 & 49,42 & 58,41 & 85,31 & 211,44 & 169,89 & 16,64 & 744,27 & 701 & 2465 \\
\hline Alsótelekes & 171 & 210,92 & 15,47 & 37,35 & 127,92 & 152,77 & 132,49 & 24,33 & 663,90 & 913 & 2763 \\
\hline Alsótold & 256 & 199,72 & 64,57| & 87,66 & 144,89 & 247,90 & 189,38 & 50,86 & 897,33 & 224 & 1248 \\
\hline Andrásfa & 302 & 212,62 & 37,13 & 56,32 & 76,03 & 197,87 & 173,49 & 27,93 & 725,05 & 761 & 2556 \\
\hline Apácatorna & 190 & 194,91 & 27,72 & 29,25 & 104,72 & 211,51 & 152,08 & \begin{tabular}{l|l}
27,88 \\
\end{tabular} & 718,81 & 778 & 2578 \\
\hline Apátistvánfalva & 392 & 208,67 & 156,02 & 158,31 & 157,44 & 237,56 & 167,90 & 30,18 & 957,78 & 121 & 766 \\
\hline Apátvarasd & 137 & 216,26 & 14,09 & 17,62 & 82,63 & 156,76 & 188,22 & 49,57 & 707,52 & 813 & 2625 \\
\hline Aranyosgadány & 385 & 235,55 & 31,51 & 71,88 & 151,34 & 189,58 & $\mid 186,86$ & 6,37 & 801,21 & 499 & 2082 \\
\hline Arka & 119 & 208,50 & 45,89 & 98,12 & 119,32 & 256,21 & 137,78 & 140,60 & 908,30 & 205 & 1164 \\
\hline Árpás & 263 & 188,93 & 61,93 & 73,59 & 228,66 & 241,14 & 187,86 & 19,32 & 927,83 & 163 & 983 \\
\hline Aszófö & 437 & 267,95 & 97,45 & 121,99 & 230,47 & 257,29 & 219,61 & 119,44 & 1192,21 & 11 & 78 \\
\hline$\overline{A ́ t a}$ & 217 & 205,15 & 59,60 & 79,22 & 161,25 & 201,26 & 162,23 & 0,00 & 789,50 & 549 & 2188 \\
\hline Babarcszölös & 143 & 205,49 & 48,34 & 61,49 & 133,82 & 135,86 & \begin{tabular}{ll|}
168,42 \\
\end{tabular} & 8,74 & 700,67 & 831 & 2649 \\
\hline Babosdöbréte & 520 & 249,35 & 38,62 & 64,28 & 198,24 & 241,48 & 203,31 & 8,94 & 939,93 & 146 & 887 \\
\hline Bácsszentgyörgy & 182 & 178,41 & 26,21 & 36,70 & 134,03 & 202,65 & 84,55 & 10,79 & 636,64 & 979 & 2833 \\
\hline Bácsszölös & 365 & 188,64 & 32,65 & 34,67 & 107,58 & 184,89 & 129,01 & 16,72 & 659,49 & 927 & 2779 \\
\hline Baglad & 61 & 156,71 & 32,05 & 24,94 & 172,22 & 285,41 & 172,90 & 51,75 & 871,04 & 288 & 1486 \\
\hline Bakháza & 204 & 185,80 & 26,31 & 24,54 & 144,78 & 173,16 & 142,04 & \begin{tabular}{l|}
12,01 \\
\end{tabular} & 684,09 & 872 & 2705 \\
\hline Bakóca & 326 & 180,92 & 50,74 & 37,69 & 71,16 & 123,54 & 165,63 & 17,45 & 609,44 & 1010 & 2870 \\
\hline Bakonybánk & 485 & 201,13 & 40,41 & 41,27 & 138,97 & 218,54 & 176,00 & 20,11 & 795,16 & 527 & 2137 \\
\hline Bakonygyirót & 162 & 178,19 & 56,46 & 71,57 & 153,16 & 227,61 & 171,46 & 10,00 & 796,88 & 516 & 2118 \\
\hline Bakonykoppány & 210 & 173,66 & 83,20 & 107,48 & 149,43 & 231,23 & 158,03 & 39,96 & 835,51 & 388 & 1814 \\
\hline Bakonykúti & 132 & 258,57 & 149,02 & 146,55 & 172,60 & 295,77 & \begin{tabular}{|l|}
175,78 \\
\end{tabular} & 28,57 & 1080,31 & 30 & 210 \\
\hline Bakonyoszlop & 489 & 201,16 & 36,56 & 64,21 & 185,16 & 198,92 & 163,84 & 49,43 & 835,07 & 389 & 1822 \\
\hline Bakonypéterd & 285 & 220,30 & 43,43 & 56,32 & 121,09 & 240,58 & 183,36 & 8,60 & 817,37 & 441 & 1959 \\
\hline Bakonypölöske & 401 & 200,12 & 40,27 & 65,45 & 136,05 & 199,99 & 173,16 & 34,79 & 784,37 & 572 & 2230 \\
\hline Bakonyság & 78 & 146,02 & 53,55 & 56,35 & 156,88 & 196,26 & 154,08 & 46,17 & 752,97 & 669 & 2412 \\
\hline Bakonyszentiván & 230 & 184,24 & 49,32 & 75,03 & 161,37 & 181,32 & 144,09 & 31,73 & 752,06 & 675 & 2418 \\
\hline Bakonyszücs & 339 & 193,83 & 66,99 & 75,12 & 136,74 & 202,89 & 152,11 & 45,46 & 798,01 & 513 & 2110 \\
\hline Baktüttös & 349 & 208,53 & 37,11 & 46,10 & 142,18 & 191,76 & \begin{tabular}{ll|}
188,47 \\
\end{tabular} & 22,15 & 790,20 & 543 & 2177 \\
\hline Balajt & 491 & 254,14 & 16,44 & 14,27 & 47,93 & 73,78 & 179,30 & 9,98 & 581,57 & 1040 & 2901 \\
\hline Balatoncsicsó & 231 & 283,72 & 93,99 & 162,47 & 123,68 & 269,24 & 163,73 & 108,68 & 1043,05 & 52 & 326 \\
\hline Balatonhenye & 124 & 171,41 & 44,89 & 49,98 & 81,04 & 200,25 & $\begin{array}{ll}160,72 \\
\end{array}$ & 77,84 & 736,14 & 729 & 2509 \\
\hline Balatonmagyaród & 498 & 188,97 & 47,73 & 59,39 & 221,98 & 247,52 & 174,62 & 61,76 & 942,58 & 143 & 860 \\
\hline Balatonrendes & 149 & 231,50 & 121,53 & 162,59 & 284,87 & 262,98 & 192,33 & 217,41 & 1310,62 & 5 & 25 \\
\hline Balatonszepezd & 438 & 247,36 & 101,69 & 128,34 & 320,25 & 263,10 & 177,31 & 288,50 & 1398,21 & 3 & 14 \\
\hline Balatonszölös & 633 & 296,91 & 58,63 & 89,86 & 162,09 & 242,32 & 217,76 & 84,09 & 1061,81 & 39 & 264 \\
\hline Balatonudvari & 378 & 247,82 & 102,44 & 134,38 & 291,07 & 262,09 & 211,04 & 320,34 & 1434,80 & 2 & 8 \\
\hline Bánfa & 198 & 217,33 & 25,70 & 28,56 & 58,28 & 111,34 & 180,37 & 0,00 & 593,02 & 1030 & 2890 \\
\hline Baranyahidvég & 209 & 196,39 & 30,74 & 39,19 & 57,84 & 130,58 & 159,45 & $\begin{array}{ll}11,73 \\
\end{array}$ & 586,72 & 1036 & 2897 \\
\hline Baranyajenö & 486 & 218,10 & 28,43 & 31,14 & 137,19 & 152,18 & 189,49 & 17,52 & 742,90 & 703 & 2468 \\
\hline Baranyaszentgyörgy & 148 & 145,20 & 21,72 & 39,06 & 126,41 & 180,97 & 173,12 & 21,57 & 668,99 & 899 & 2746 \\
\hline Barlahida & 176 & 191,44 & 60,60 & 76,74 & 176,14 & 249,03 & 178,35 & 34,45 & 890,02 & 245 & 1304 \\
\hline Barnag & 146 & 243,83 & 73,41 & 120,83 & 184,05 & 216,31 & 181,59 & 36,81 & 936,00 & 153 & 919 \\
\hline
\end{tabular}




\begin{tabular}{|c|c|c|c|c|c|c|c|c|c|c|c|}
\hline Településnév & $\begin{array}{l}\text { Népesség- } \\
\text { szám, } 2010\end{array}$ & $\begin{array}{l}\text { Népes- } \\
\text { ség }\end{array}$ & $\begin{array}{l}\text { Társa- } \\
\text { dalom }\end{array}$ & $\begin{array}{l}\text { Társa- } \\
\text { dalom } \\
(2011)\end{array}$ & Ellátottság & Gazdaság & $\begin{array}{l}\text { Közle- } \\
\text { kedés }\end{array}$ & $\begin{array}{c}\text { Idegen- } \\
\text { forgalom }\end{array}$ & $\begin{array}{l}\text { Összfej- } \\
\text { lettség }\end{array}$ & $\begin{array}{c}\begin{array}{c}\text { H. Apró- } \\
\text { falu }\end{array} \\
\end{array}$ & $\begin{array}{c}\begin{array}{c}\text { H. Fal- } \\
\text { vak }\end{array} \\
\end{array}$ \\
\hline Basal & 210 & 235,66 & 29,75 & 36,02 & 128,76 & 174,39 & 186,95 & 23,34 & 778,85 & 591 & 2267 \\
\hline Baskó & 199 & 178,88 & 40,38 & 97,30 & 80,05 & 223,36 & 106,67 & 86,12 & 715,46 & 790 & 2595 \\
\hline Bátaapáti & 429 & 226,07 & 43,97 & 55,62 & 178,17 & 223,54 & 185,75 & 75,80 & 933,30 & 155 & 944 \\
\hline Bátor & 396 & 197,19 & 84,55 & 86,70 & 206,83 & 216,19 & 175,99 & 27,75 & 908,49 & 204 & 1161 \\
\hline Batyk & 415 & 207,36 & 35,52 & 46,89 & 190,65 & 206,80 & 196,29 & 10,93 & 847,55 & 352 & 1709 \\
\hline Bazsi & 427 & 177,48 & 46,78 & 55,74 & 174,89 & 189,00 & 163,85 & 36,13 & 788,13 & 553 & 2197 \\
\hline Béb & 264 & 251,84 & 71,33 & 115,83 & 182,11 & 220,16 & 169,89 & 24,06 & 919,40 & 182 & 1063 \\
\hline Becskeháza & 45 & 158,49 & 22,44 & 20,12 & 94,31 & 203,78 & 93,62 & 0,00 & 572,64 & 1043 & 2905 \\
\hline Bedegkér & 481 & 192,42 & 38,20 & 39,35 & 178,10 & 141,99 & 140,64 & 5,10 & 696,44 & 845 & 2668 \\
\hline Bedö & 273 & 162,67 & 154,89 & 138,76 & 153,50 & 235,77 & 141,12 & 26,93 & 874,88 & 281 & 1464 \\
\hline Bejcgyertyános & 475 & 187,43 & 54,24 & 57,21 & 152,48 & 238,43 & 177,71 & 37,42 & 847,71 & 349 & 1702 \\
\hline Békás & 219 & 204,67 & 36,14 & 37,45 & 239,09 & 229,33 & 164,69 & 14,79 & 888,70 & 249 & 1317 \\
\hline Bélavár & 400 & 171,70 & 35,04 & 38,07 & 207,81 & 203,92 & 113,45 & 16,13 & 748,04 & 691 & 2440 \\
\hline Belecska & 412 & 232,79 & 49,40 & 41,74 & 105,66 & 220,02 & 140,82 & 0,00 & 748,68 & 688 & 2437 \\
\hline Belsősárd & 104 & 189,87 & 36,08 & 54,17 & 251,28 & 244,59 & 185,43 & 7,57 & 914,82 & 193 & 1110 \\
\hline Belvárdgyula & 453 & 221,71 & 50,56 & 54,02 & 158,32 & 205,31 & 160,46 & 16,23 & 812,60 & 461 & 1999 \\
\hline Benk & 454 & 202,02 & 36,86 & 48,49 & 147,45 & 197,05 & 137,73 & 20,80 & 741,90 & 708 & 2476 \\
\hline Bér & 381 & 176,61 & 93,84 & 119,31 & 146,06 & 191,38 & 134,33 & 19,62 & 761,86 & 636 & 2358 \\
\hline Beret & 283 & 256,26 & 26,11 & 26,20 & 115,87 & 85,64 & 164,39 & 18,66 & 666,93 & 904 & 2752 \\
\hline Besence & 132 & 206,26 & 47,12 & 53,21 & 61,70 & 101,93 & 166,18 & 8,77 & 591,95 & 1032 & 2892 \\
\hline Bezedek & 271 & 189,62 & 62,26 & 74,65 & 108,96 & 206,80 & 164,26 & 18,09 & 749,99 & 683 & 2431 \\
\hline Bezeréd & 172 & 152,10 & 49,89 & 79,11 & 185,74 & 202,64 & 170,89 & 25,02 & 786,28 & 566 & 2218 \\
\hline$\overline{B e z i}$ & 537 & 269,62 & 49,63 & 83,96 & 140,83 & 247,01 & 186,94 & 9,74 & 903,76 & 211 & 1197 \\
\hline Bihardancsháza & 195 & 186,83 & 23,84 & 24,85 & 133,49 & 189,31 & 132,35 & 25,14 & 690,96 & 859 & 2686 \\
\hline Bikács & 452 & 203,58 & 32,07 & 43,66 & 120,11 & 189,24 & 153,80 & 62,77 & 761,57 & 637 & 2360 \\
\hline Birján & 561 & 307,84 & 48,00 & 100,13 & 139,11 & 215,43 & 189,00 & 4,37 & 903,75 & 212 & 1198 \\
\hline Bisse & 252 & 216,05 & 34,06 & 56,88 & 96,66 & 176,49 & 197,83 & 22,85 & 743,94 & 702 & 2466 \\
\hline Bocska & 373 & 225,75 & 23,43 & 38,72 & 85,74 & 186,75 & 183,93 & 16,49 & 722,08 & 770 & 2568 \\
\hline Boda & 441 & 243,09 & 51,38 & 75,04 & 168,20 & 199,53 & 198,14 & 44,45 & 904,79 & 209 & 1190 \\
\hline Bodmér & 249 & 231,17 & 68,07 & 94,40 & 191,71 & 235,48 & 195,71 & 10,00 & 932,14 & 157 & 951 \\
\hline Bodolyabér & 258 & 166,68 & 21,33 & 33,86 & 135,21 & 180,19 & 179,59 & 34,10 & 717,11 & 783 & 2584 \\
\hline Bodonhely & 309 & 200,81 & 61,15 & 73,66 & 180,70 & 263,22 & 190,37 & 16,89 & 913,14 & 195 & 1122 \\
\hline \begin{tabular}{|l|} 
Bodorfa \\
\end{tabular} & 116 & 163,34 & 9,70 & 22,36 & 83,26 & 183,46 & 162,50 & 15,72 & 617,99 & 999 & 2858 \\
\hline Bodrog & 441 & 204,47 & 71,52 & 77,96 & 120,94 & 216,56 & 175,62 & 32,74 & 821,86 & 427 & 1915 \\
\hline Bódvalenke & 210 & 261,95 & 22,81 & 10,72 & 91,05 & 87,62 & 88,69 & 0,00 & 552,12 & 1058 & 2920 \\
\hline Bódvarákó & 109 & 156,81 & 36,02 & 35,89 & 57,31 & 179,04 & 121,58 & 50,00 & 600,76 & 1020 & 2880 \\
\hline Bogádmindszent & 453 & 223,39 & 51,87 & 55,19 & 156,13 & 175,13 & 162,22 & 17,06 & 785,80 & 569 & 2221 \\
\hline Bogdása & 314 & 191,93 & 46,16 & 48,82 & 158,62 & 175,59 & 174,80 & 33,04 & 780,14 & 585 & 2258 \\
\hline Bókaháza & 316 & 203,92 & 34,13 & 42,76 & 161,60 & 180,56 & 173,07 & 41,60 & 794,87 & 528 & 2139 \\
\hline Bokor & 137 & 185,68 & 72,26 & 101,58 & 118,38 & 216,79 & 150,03 & 19,05 & 762,19 & 635 & 2357 \\
\hline Boldogasszonyfa & 458 & 193,62 & 47,73 & 66,54 & 137,27 & 143,18 & 163,60 & 75,84 & 761,24 & 640 & 2363 \\
\hline Bolhás & 458 & 192,52 & 35,73 & 37,24 & 158,25 & 156,53 & 166,14 & 21,41 & 730,58 & 744 & 2532 \\
\hline Boncodfölde & 343 & 380,44 & 62,08 & 96,31 & 156,14 & 260,86 & 211,43 & 37,60 & 1108,54 & 24 & 164 \\
\hline Bonnya & 282 & 185,30 & 47,99 & 64,69 & 104,01 & 167,50 & 144,22 & 66,43 & 715,46 & 791 & 2596 \\
\hline Bonyhádvarasd & 464 & 196,91 & 35,49 & 60,56 & 190,36 & 234,50 & 197,06 & 29,39 & 883,72 & 263 & 1370 \\
\hline Borgáta & 161 & 192,49 & 37,72 & 49,00 & 182,54 & 248,44 & 169,12 & 210,00 & 1040,32 & 55 & 338 \\
\hline Borjád & 452 & 208,62 & 99,64 & 107,52 & 187,27 & 237,24 & 173,63 & 44,81 & 951,20 & 131 & 804 \\
\hline Borsodgeszt & 286 & 181,45 & 38,34 & 63,36 & 236,44 & 215,14 & 157,97 & 18,57 & 847,91 & 347 & 1700 \\
\hline Borszörcsök & 414 & 200,63 & 12,97 & 26,47 & 105,38 & 182,79 & 169,02 & 23,91 & 694,71 & 853 & 2676 \\
\hline Bosta & 156 & 215,50 & 32,20 & 46,47 & 126,38 & 137,50 & 178,82 & 4,75 & 695,15 & 850 & 2673 \\
\hline Botykapeterd & 364 & 202,97 & 26,23 & 41,93 & 121,37 & 153,76 & 209,64 & 59,97 & 773,95 & 599 & 2285 \\
\hline Bozsok & 365 & 194,86 & 101,22 & 116,65 & 182,21 & 257,97 & 205,13 & 98,98 & 1040,37 & 54 & 335 \\
\hline Bozzai & 333 & 237,60 & 33,53 & 47,55 & 149,81 & 228,24 & 195,57 & 21,60 & 866,36 & 303 & 1529 \\
\hline Bózsva & 199 & 183,65 & 69,05 & 82,44 & 175,28 & 215,00 & 133,43 & 153,21 & 929,64 & 161 & 970 \\
\hline Böde & 312 & 219,59 & 32,04 & 41,18 & 110,05 & 226,89 & 196,20 & 31,27 & 816,03 & 448 & 1971 \\
\hline Bödeháza & 60 & 152,01 & 56,75 & 85,36 & 151,78 & 253,28 & 166,13 & 30,45 & 810,40 & 467 & 2016 \\
\hline Bögöt & 397 & 229,92 & 35,66 & 53,00 & 166,72 & 243,34 & 190,27 & 17,03 & 882,95 & 265 & 1376 \\
\hline Bögöte & 318 & 198,24 & 47,41 & 61,78 & 236,36 & 244,86 & 147,56 & 65,89 & 940,33 & 145 & 885 \\
\hline Börzönce & 57 & 177,38 & 15,63 & 27,64 & 140,41 & 239,24 & 163,05 & 2,84 & 738,56 & 717 & 2494 \\
\hline Bucsuta & 225 & 182,11 & 26,49 & 43,37 & 114,83 & 169,61 & 149,14 & 44,54 & 686,73 & 867 & 2699 \\
\hline Bugacpusztaháza & 303 & 189,26 & 19,41 & 32,98 & 89,25 & 230,58 & 174,80 & 44,27 & 747,56 & 694 & 2447 \\
\hline Bükkmogyorósd & 149 & 149,80 & 25,72 & 35,27 & 236,11 & 187,45 & 153,46 & 0,00 & 752,54 & 673 & 2416 \\
\hline Bükkszentmárton & 332 & 194,44 & 57,80 & 60,02 & 143,21 & 160,32 & 203,16 & 33,07 & 791,99 & 540 & 2163 \\
\hline Bürüs & 96 & 192,10 & 41,37 & 41,86 & 57,14 & 151,10 & 166,63 & 0,00 & 608,34 & 1011 & 2871 \\
\hline Büssü & 411 & 200,09 & 30,98 & 30,65 & 82,61 & 169,30 & 146,64 & 21,93 & 651,55 & 946 & 2799 \\
\hline Büttös & 215 & 158,46 & 33,38 & 43,37 & 86,39 & 164,87 & 123,66 & 22,80 & 589,56 & 1035 & 2896 \\
\hline Cák & 287 & 255,94 & 123,64 & 146,99 & 157,31 & 257,73 & 207,40 & 74,98 & 1076,99 & 31 & 215 \\
\hline Cakóháza & 58 & 182,26 & 51,18 & 54,58 & 114,82 & 262,14 & 168,63 & 0,00 & 779,04 & 590 & 2266 \\
\hline Chernelházadamonya & 225 & 215,53 & 37,18 & 54,73 & 238,65 & 222,53 & 172,62 & 25,39 & 911,90 & 199 & 1130 \\
\hline Csabaszabadi & 380 & 193,39 & 74,90 & 105,34 & 135,03 & 200,00 & 181,22 & 44,72 & 829,26 & 407 & 1872 \\
\hline Csáfordjánosfa & 212 & 146,80 & 40,31 & 50,09 & 156,94 & 245,68 & 98,49 & 21,56 & 709,78 & 807 & 2616 \\
\hline
\end{tabular}




\begin{tabular}{|c|c|c|c|c|c|c|c|c|c|c|c|}
\hline Településnév & $\begin{array}{l}\text { Népesség- } \\
\text { szám, } 2010\end{array}$ & $\begin{array}{l}\text { Népes- } \\
\text { ség }\end{array}$ & $\begin{array}{l}\text { Társa- } \\
\text { dalom }\end{array}$ & $\begin{array}{l}\text { Társa- } \\
\text { dalom } \\
(2011) \\
\end{array}$ & Ellátottság & Gazdaság & $\begin{array}{l}\text { Közle- } \\
\text { kedés }\end{array}$ & $\begin{array}{c}\text { Idegen- } \\
\text { forgalom }\end{array}$ & $\begin{array}{l}\text { Összfej- } \\
\text { lettség }\end{array}$ & $\begin{array}{c}\begin{array}{c}\text { H. Apró- } \\
\text { falu }\end{array} \\
\end{array}$ & \begin{tabular}{|c}
$\begin{array}{c}\text { H. Fal- } \\
\text { vak }\end{array}$ \\
\end{tabular} \\
\hline Csákány & 300 & 201,72 & 43,93 & 49,99 & 152,00 & 141,55 & 132,00 & 0,00 & 671,20 & 895 & 2742 \\
\hline Csanádalberti & 485 & 205,93 & 46,54 & 48,24 & 147,26 & 198,94 & 137,90 & 24,90 & 761,47 & 638 & 2361 \\
\hline Csánig & 380 & 196,74 & 57,50 & 67,46 & 153,56 & 240,75 & 151,14 & 16,81 & 816,49 & 444 & 1965 \\
\hline Csapi & 169 & 225,96 & 77,94 & 82,94 & 154,06 & 222,64 & 162,89 & 30,00 & 873,48 & 285 & 1473 \\
\hline Csarnóta & 147 & 206,09 & 28,98 & 49,45 & 117,59 & 179,85 & 207,73 & 43,35 & 783,58 & 578 & 2239 \\
\hline Császló & 380 & 212,01 & 22,04 & 27,83 & 105,76 & 207,26 & 109,46 & 22,90 & 679,43 & 881 & 2716 \\
\hline Csataszög & 355 & 239,00 & 34,56 & 44,46 & 204,36 & 204,00 & 168,39 & 6,90 & 857,21 & 320 & 1619 \\
\hline Csatka & 280 & 179,18 & 47,51 & 62,56 & 155,07 & 217,63 & 150,39 & 28,75 & 778,52 & 594 & 2271 \\
\hline Csebény & 104 & 201,23 & 43,59 & 43,82 & 59,60 & 87,13 & 141,69 & 36,92 & 570,16 & 1044 & 2906 \\
\hline Csehbánya & 281 & 231,28 & 30,28 & 98,51 & 136,85 & 213,50 & 180,86 & 28,11 & 820,89 & 429 & 1923 \\
\hline Csehi & 276 & 189,67 & 44,43 & 42,34 & 179,35 & 197,19 & 169,57 & 12,24 & 792,44 & 535 & 2157 \\
\hline Csehimindszent & 381 & 182,94 & 73,76 & 67,84 & 236,24 & 213,43 & 172,73 & 57,20 & 936,29 & 152 & 914 \\
\hline Csém & 466 & 227,04 & 16,99 & 30,53 & 160,29 & 230,46 & 209,43 & 33,16 & 877,38 & 276 & 1434 \\
\hline Csempeszkopács & 329 & 247,81 & 59,06 & 74,31 & 205,14 & 251,38 & 190,72 & 68,34 & 1022,45 & 68 & 414 \\
\hline Csenyéte & 541 & 312,87 & 4,04 & 0,00 & 56,64 & 46,35 & 126,33 & 0,00 & 546,23 & 1061 & 2923 \\
\hline Csép & 387 & 218,43 & 23,84 & 30,76 & 138,98 & 208,14 & 189,05 & 16,33 & 794,77 & 529 & 2140 \\
\hline Csér & 40 & 149,17 & 41,67 & 56,01 & 103,98 & 246,41 & 87,40 & 0,00 & 628,63 & 988 & 2842 \\
\hline Cserdi & 426 & 266,48 & 25,90 & 28,63 & 86,63 & 124,23 & 197,37 & 20,54 & 721,15 & 773 & 2572 \\
\hline Cserénfa & 234 & 181,27 & 56,30 & 66,79 & 112,34 & 201,25 & 184,30 & 35,05 & 770,52 & 610 & 2304 \\
\hline Cserépváralja & 455 & 172,56 & 34,90 & 46,43 & 214,41 & 232,63 & 145,62 & 59,94 & 860,07 & 315 & 1585 \\
\hline Cserháthaláp & 399 & 207,49 & 48,82 & 63,68 & 171,67 & 212,35 & 161,83 & 28,29 & 830,45 & 403 & 1860 \\
\hline Cserhátszentiván & 156 & 180,46 & 73,82 & 104,62 & 185,41 & 223,06 & 178,72 & 37,73 & 879,20 & 270 & 1413 \\
\hline Cserkút & 564 & 314,90 & 96,83 & 112,28 & 171,01 & 232,89 & 210,46 & 43,04 & 1069,13 & 35 & 244 \\
\hline Csertalakos & 36 & 133,23 & 11,14 & 31,30 & 110,66 & 159,00 & 159,29 & 16,43 & 589,75 & 1034 & 2895 \\
\hline Csertö & 437 & 211,48 & 46,21 & 53,90 & 190,62 & 192,19 & 184,90 & 41,05 & 866,45 & 302 & 1528 \\
\hline Csesztve & 337 & 205,53 & 38,55 & 62,90 & 226,69 & 219,95 & 160,07 & 34,37 & 885,15 & 259 & 1350 \\
\hline Csibrák & 347 & 175,96 & 27,44 & 37,91 & 100,20 & 156,25 & 161,21 & 32,04 & 653,10 & 943 & 2796 \\
\hline Csikvánd & 498 & 192,88 & 38,06 & 45,21 & 200,76 & 220,39 & 189,87 & 9,84 & 851,80 & 334 & 1665 \\
\hline Csipkerek & 367 & 167,19 & 41,99 & 59,97 & 213,22 & 222,13 & 176,82 & 17,07 & 838,43 & 380 & 1785 \\
\hline Csitár & 443 & 197,25 & 46,12 & 54,95 & 207,90 & 203,01 & 173,66 & 42,13 & 870,07 & 292 & 1500 \\
\hline Csoma & 475 & 213,24 & 75,18 & 77,68 & 115,64 & 194,36 & 169,51 & 20,32 & 788,25 & 552 & 2195 \\
\hline Csombárd & 290 & 189,19 & 52,43 & 60,85 & 119,91 & 205,91 & 193,53 & 35,35 & 796,34 & 520 & 2125 \\
\hline Csonkahegyhát & 365 & 243,77 & 86,13 & 99,95 & 218,60 & 253,25 & 201,06 & 24,97 & 1027,78 & 64 & 386 \\
\hline Csonkamindszent & 180 & 249,09 & 19,73 & 30,56 & 114,04 & 185,80 & 201,85 & 13,62 & 784,13 & 574 & 2232 \\
\hline Csöde & 85 & 212,13 & 61,12 & 83,50 & 162,32 & 205,53 & 154,99 & 242,80 & 1038,90 & 57 & 345 \\
\hline Csömend & 332 & 196,70 & 28,09 & 31,09 & 137,78 & 184,04 & 188,90 & 7,38 & 742,90 & 704 & 2469 \\
\hline Csönge & 428 & 199,48 & 27,39 & 32,89 & 191,48 & 227,97 & 166,62 & 29,34 & 842,29 & 366 & 1751 \\
\hline Csörnyeföld & 455 & 204,45 & 39,54 & 54,87 & 186,10 & 168,57 & 159,14 & 31,38 & 789,17 & 550 & 2190 \\
\hline Csurgónagymarton & 173 & 184,90 & 60,84 & 67,74 & 105,88 & 164,91 & 157,90 & 44,70 & 719,14 & 777 & 2577 \\
\hline Cún & 260 & 216,74 & 15,46 & 23,59 & 47,88 & 115,08 & 145,94 & 25,66 & 566,77 & 1047 & 2909 \\
\hline Dabrony & 430 & 209,55 & 51,66 & 57,78 & 187,19 & 237,07 & 149,18 & 32,37 & 867,01 & 300 & 1526 \\
\hline Damak & 264 & 201,96 & 24,57 & 46,60 & 101,33 & 194,57 & 185,58 & 18,57 & 726,57 & 757 & 2549 \\
\hline Dámóc & 429 & 218,07 & 31,00 & 25,86 & 119,05 & 128,77 & 81,33 & 5,71 & 583,93 & 1039 & 2900 \\
\hline Daraboshegy & 103 & 197,23 & 19,52 & 32,83 & 113,63 & 232,87 & 191,84 & 84,41 & 839,51 & 373 & 1772 \\
\hline Darnó & 174 & 280,68 & 20,51 & 17,32 & 140,51 & 137,15 & 127,83 & 20,00 & 726,68 & 756 & 2548 \\
\hline Debercsény & 84 & 152,77 & 19,90 & 25,64 & 280,54 & 212,50 & 145,94 & 33,86 & 845,51 & 357 & 1723 \\
\hline Debréte & 19 & 81,25 & 19,18 & 71,93 & 58,63 & 145,57 & 110,47 & 100,00 & 515,10 & 1070 & 2933 \\
\hline Dénesfa & 434 & 206,92 & 26,10 & 44,95 & 131,14 & 224,36 & 144,73 & 56,94 & 790,19 & 544 & 2178 \\
\hline Detek & 306 & 194,87 & 25,42 & 36,36 & 135,98 & 137,93 & 167,56 & 18,01 & 679,77 & 880 & 2715 \\
\hline \begin{tabular}{|l} 
Dinnyeberki \\
\end{tabular} & 96 & 157,18 & 69,66 & 78,52 & 92,28 & 181,97 & 184,19 & 35,53 & 720,81 & 774 & 2573 \\
\hline 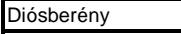 & 369 & 185,08 & 54,52 & 75,09 & 137,48 & 204,81 & 153,51 & 20,56 & 755,96 & 664 & 2403 \\
\hline Dobri & 202 & 169,35 & 49,61 & 52,18 & 196,76 & 194,74 & 155,99 & 30,96 & 797,41 & 515 & 2115 \\
\hline Dobronhegy & 145 & 193,19 & 53,21 & 76,50 & 172,96 & 252,17 & 219,27 & 133,61 & 1024,41 & 65 & 401 \\
\hline Dozmat & 228 & 306,81 & 69,82 & 112,35 & 202,12 & 239,75 & 225,85 & 11,82 & 1056,16 & 42 & 282 \\
\hline Döbörhegy & 161 & 160,37 & 42,92 & 55,62 & 200,86 & 235,14 & 168,39 & 18,24 & 825,92 & 413 & 1888 \\
\hline Döbröce & 73 & 176,27 & 38,40 & 37,04 & 130,51 & 216,05 & 176,40 & 40,03 & 777,66 & 596 & 2274 \\
\hline Döbrönte & 267 & 220,68 & 50,20 & 99,42 & 176,06 & 255,43 & 171,58 & 171,32 & 1045,27 & 50 & 317 \\
\hline Dörgicse & 317 & 241,26 & 76,54 & 105,78 & 218,24 & 235,98 & 170,26 & 112,45 & 1054,72 & 44 & 288 \\
\hline Döröske & 92 & 146,86 & 43,60 & 90,38 & 154,73 & 233,40 & 193,10 & 39,15 & 810,84 & 465 & 2010 \\
\hline Dötk & 25 & 219,67 & 84,65 & 165,38 & 168,05 & 217,09 & 187,75 & 0,00 & 877,21 & 278 & 1437 \\
\hline Dövény & 308 & 206,47 & 31,36 & 45,25 & 120,56 & 164,61 & 158,73 & 7,96 & 689,69 & 862 & 2690 \\
\hline Drágszél & 381 & 189,84 & 48,16 & 46,89 & 168,15 & 225,36 & 141,89 & 6,43 & 779,84 & 587 & 2261 \\
\hline Drávacsehi & 244 & 212,57 & 13,64 & 14,54 & 110,51 & 133,94 & 166,70 & 20,00 & 657,37 & 936 & 2789 \\
\hline Drávacsepely & 225 & 189,10 & 22,29 & 27,15 & 143,55 & 207,33 & 167,86 & 34,13 & 764,26 & 630 & 2340 \\
\hline Drávagárdony & 153 & 204,14 & 33,42 & 33,80 & 152,30 & 147,96 & 144,15 & 41,84 & 723,81 & 766 & 2563 \\
\hline Drávaiványi & 221 & 195,49 & 28,08 & 16,43 & 118,08 & 136,87 & 165,91 & 45,59 & 690,02 & 861 & 2688 \\
\hline Drávakeresztúr & 121 & 157,17 & 113,73 & 65,92 & 157,23 & 98,94 & 146,92 & 30,26 & 704,25 & 820 & 2636 \\
\hline Drávapalkonya & 292 & 213,62 & 19,99 & 14,22 & 116,80 & 96,82 & 167,68 & 26,79 & 641,70 & 965 & 2818 \\
\hline Drávapiski & 127 & 259,80 & 8,48 & 5,18 & 83,56 & 164,18 & 151,79 & 19,30 & 687,12 & 866 & 2698 \\
\hline Drávaszerdahely & 211 & 205,19 & 57,69 & 57,10 & 154,36 & 232,36 & 191,59 & 53,96 & 895,16 & 231 & 1266 \\
\hline Drávasztára & 458 & 192,00 & 117,46 & 99,46 & 137,43 & 182,26 & 168,35 & 44,25 & 841,74 & 368 & 1755 \\
\hline
\end{tabular}




\begin{tabular}{|c|c|c|c|c|c|c|c|c|c|c|c|}
\hline Településnév & $\begin{array}{l}\text { Népesség- } \\
\text { szám, } 2010\end{array}$ & $\begin{array}{l}\text { Népes- } \\
\text { ség }\end{array}$ & $\begin{array}{l}\text { Társa- } \\
\text { dalom }\end{array}$ & $\begin{array}{l}\text { Társa- } \\
\text { dalom } \\
\text { (2011) }\end{array}$ & Ellátottság & Gazdaság & $\begin{array}{l}\text { Közle- } \\
\text { kedés }\end{array}$ & $\begin{array}{c}\text { Idegen- } \\
\text { forgalom }\end{array}$ & $\begin{array}{l}\text { Összfej- } \\
\text { lettség }\end{array}$ & $\begin{array}{c}\text { H. Apró- } \\
\text { falu }\end{array}$ & $\begin{array}{c}\text { H. Fal- } \\
\text { vak }\end{array}$ \\
\hline Drávatamási & 411 & 229,93 & 23,28 & 48,70 & 148,40 & 204,99 & 141,48 & 17,03 & 765,11 & 627 & 2335 \\
\hline Dubicsány & 320 & 215,86 & 47,82 & 62,46 & 166,86 & 196,87 & 169,45 & 28,25 & 825,10 & 416 & 1896 \\
\hline Duka & 280 & 181,32 & 37,30 & 48,24 & 192,44 & 214,02 & 155,35 & 34,53 & 814,96 & 452 & 1976 \\
\hline Dunaremete & 255 & 236,90 & 73,93 & 87,98 & 168,10 & 258,17 & 185,92 & 28,84 & 951,86 & 130 & 799 \\
\hline Dunaszentmiklós & 444 & 248,50 & 119,66 & 158,41 & 213,68 & 255,11 & 203,87 & 116,07 & 1156,89 & 15 & 99 \\
\hline Dúzs & 276 & 198,66 & 26,62 & 28,87 & 99,29 & 192,13 & 153,25 & 13,69 & 683,65 & 873 & 2706 \\
\hline Ebergöc & 151 & 251,68 & 45,75 & 55,58 & 259,11 & 230,87 & 138,30 & 26,23 & 951,94 & 129 & 797 \\
\hline Ecseny & 241 & 143,94 & 49,94 & 76,35 & 112,30 & 199,37 & 153,00 & 10,17 & 668,72 & 900 & 2747 \\
\hline Edde & 212 & 178,70 & 38,80 & 42,61 & 155,21 & \begin{tabular}{|l|}
159,97 \\
\end{tabular} & 163,73 & 11,56 & 707,97 & 812 & 2624 \\
\hline Edve & 129 & 165,91 & 44,73 & 60,34 & 191,61 & 295,26 & 160,34 & 29,00 & 886,86 & 254 & 1335 \\
\hline Egeralja & 242 & 197,51 & 35,78 & 41,02 & 170,33 & 208,70 & 142,84 & 52,82 & 807,98 & 475 & 2031 \\
\hline Egeraracsa & 354 & 198,81 & 13,72 & 25,20 & 103,39 & 175,85 & 178,82 & 12,22 & 682,82 & 876 & 2710 \\
\hline Égerszög & 63 & 131,14 & 11,55 & 30,82 & 178,05 & 238,68 & 129,14 & 230,00 & 918,56 & 184 & 1071 \\
\hline Egervölgy & 378 & 188,23 & 39,39 & 54,63 & $\begin{array}{ll}199,05 \\
\end{array}$ & 222,67 & 180,37 & 35,19 & 864,90 & 306 & 1539 \\
\hline Egyházasharaszti & 321 & 212,10 & 38,67 & 36,75 & 139,14 & 236,25 & 164,95 & 15,27 & 806,38 & 480 & 2041 \\
\hline Egyházashetye & 350 & 163,28 & 70,86 & 74,94 & 224,20 & 223,64 & 171,67 & 23,54 & 877,19 & 279 & 1438 \\
\hline Ellend & 237 & 219,18 & 56,87 & 62,32 & 132,99 & 211,69 & 195,40 & 7,81 & 823,96 & 421 & 1903 \\
\hline Endröc & 406 & 203,64 & 24,48 & 26,66 & 73,32 & 160,95 & 142,64 & 6,04 & 611,07 & 1008 & 2868 \\
\hline Eplény & 556 & 255,23 & 72,12 & 81,64 & 185,83 & 246,51 & 228,57 & 42,93 & 1031,20 & 62 & 371 \\
\hline Erdősmárok & 96 & 182,39 & 43,67 & 47,96 & 80,48 & 171,61 & 167,37 & 31,32 & 676,84 & 883 & 2722 \\
\hline Erdősmecske & 422 & 200,76 & 43,47 & 56,66 & 123,32 & 203,33 & 182,93 & 27,59 & 781,41 & 582 & 2250 \\
\hline Erzsébet & 316 & 202,06 & 49,70 & 62,96 & 163,27 & 239,67 & 202,03 & 20,58 & 877,30 & 277 & 1435 \\
\hline Esztergályhorváti & 476 & 205,14 & 41,38 & 61,69 & 116,36 & 194,27 & 175,18 & 52,16 & 784,49 & 571 & 2229 \\
\hline Fáj & 388 & 316,23 & 12,13 & 7,64 & 35,58 & 6,30 & 144,09 & 6,32 & 520,64 & 1067 & 2930 \\
\hline Fancsal & 356 & 196,93 & 47,48 & 79,41 & 146,19 & 219,12 & 188,91 & 23,77 & 822,40 & 425 & 1913 \\
\hline Farkasgyepü & 371 & 213,17 & 118,63 & 106,09 & 192,69 & 248,37 & 188,66 & 48,87 & 1010,39 & 76 & 465 \\
\hline Fazekasboda & 228 & 211,71 & 42,77 & 55,74 & 118,41 & 207,65 & 195,29 & 10,75 & 786,58 & 561 & 2212 \\
\hline Fedémes & 341 & 171,01 & 46,92 & 48,64 & 142,14 & 204,88 & 171,36 & 32,84 & 769,14 & 616 & 2313 \\
\hline Fehértó & 501 & 215,39 & 44,11 & 55,30 & 138,52 & 251,53 & 189,08 & 24,97 & 863,59 & 308 & 1555 \\
\hline Feked & 213 & 156,35 & 91,94 & 126,07 & 161,68 & 237,91 & 151,10 & 11,51 & 810,49 & 466 & 2015 \\
\hline Feketeerdő & 565 & 324,77 & 69,71 & 115,32 & 175,78 & 243,46 & 189,68 & 18,68 & 1022,08 & 69 & 416 \\
\hline Felsöberecki & 310 & 195,62 & 34,33 & 47,16 & 151,34 & 216,66 & 106,36 & 29,65 & 733,96 & 737 & 2523 \\
\hline Felsöcsatár & 489 & 230,51 & 127,74 & 144,80 & 191,06 & 245,13 & 197,26 & 38,62 & 1030,32 & 63 & 377 \\
\hline Felsöegerszeg & 134 & 189,79 & 17,35 & 21,54 & 143,24 & 184,94 & 188,65 & 29,02 & 752,99 & 668 & 2411 \\
\hline Felsögagy & 206 & 260,55 & 36,94 & 43,05 & 67,35 & 110,57 & 145,02 & 18,18 & 638,62 & 975 & 2829 \\
\hline Felsőjánosfa & 202 & 201,65 & 49,95 & 57,92 & 203,65 & 239,73 & 187,34 & 38,86 & 921,19 & 176 & 1046 \\
\hline Felsökelecsény & 404 & 206,79 & 41,84 & 47,83 & 140,22 & 161,22 & 168,32 & 6,07 & 724,46 & 764 & 2560 \\
\hline Felsömarác & 281 & 183,04 & 47,88 & 54,44 & 155,61 & 241,19 & 173,35 & 29,43 & 830,51 & 402 & 1859 \\
\hline Felsőmocsolád & 462 & 170,71 & 70,38 & 78,94 & 138,39 & 161,83 & 165,16 & 41,45 & 747,93 & 693 & 2444 \\
\hline Felsöregmec & 354 & 399,21 & 30,14 & 23,50 & 84,79 & 95,10 & 118,31 & 10,00 & 737,56 & 723 & 2502 \\
\hline Felsőszenterzsébet & 15 & 133,01 & 215,40 & 210,88 & 175,05 & 340,25 & 160,13 & 119,26 & 1143,10 & 18 & 117 \\
\hline Felsőtold & 154 & 165,50 & 58,63 & 62,98 & 191,48 & 205,09 & 184,43 & 62,59 & 867,72 & 299 & 1522 \\
\hline Fenyöfö & 131 & 164,49 & 34,09 & 36,88 & 169,38 & 210,62 & 128,12 & 54,70 & 761,40 & 639 & 2362 \\
\hline Fertöboz & 275 & 234,52 & 64,41 & 88,77 & 175,23 & 245,03 & 177,05 & 122,93 & 1019,17 & 71 & 428 \\
\hline Fertöhomok & 645 & 275,70 & 117,11 & 119,03 & 221,44 & 259,67 & 169,27 & 39,69 & 1082,88 & 28 & 206 \\
\hline Fiad & 177 & 199,89 & 22,01 & 25,71 & 116,32 & 151,94 & 126,54 & 13,85 & 630,54 & 984 & 2838 \\
\hline Filkeháza & 131 & 221,25 & 36,17 & 109,04 & 103,14 & 167,26 & 116,51 & 10,00 & 654,33 & 942 & 2795 \\
\hline Folyás & 393 & 202,79 & 22,38 & 27,95 & 93,45 & 168,89 & 174,47 & 22,47 & 684,46 & 870 & 2703 \\
\hline Fonó & 300 & 168,47 & 78,47 & 71,70 & 128,40 & 204,70 & 176,68 & 8,17 & 764,89 & 629 & 2337 \\
\hline Fony & 385 & 207,64 & 82,83 & 92,30 & 110,69 & 165,33 & 148,10 & 22,81 & 737,41 & 724 & 2503 \\
\hline Fönyed & 88 & 159,63 & 15,66 & 35,97 & 209,10 & 170,75 & 138,72 & 20,00 & 713,86 & 795 & 2600 \\
\hline Fulókércs & 391 & 260,94 & 38,41 & 38,99 & 63,94 & 85,88 & 150,33 & 16,27 & 615,78 & 1001 & 2860 \\
\hline Fülesd & 482 & 213,27 & 43,37 & 50,65 & 200,13 & 184,64 & 138,10 & 42,94 & 822,45 & 424 & 1912 \\
\hline Fülpösdaróc & 351 & 213,30 & 26,94 & 41,34 & 104,91 & 224,24 & 138,82 & 23,97 & 732,17 & 741 & 2527 \\
\hline Füzér & 461 & 175,32 & 81,62 & 105,99 & 215,00 & 255,25 & 110,95 & 88,16 & 926,31 & 168 & 1003 \\
\hline Füzérkajata & 128 & 154,65 & 19,57 & 29,94 & 164,73 & 164,49 & 107,10 & 40,28 & 650,82 & 949 & 2802 \\
\hline Füzérkomlós & 393 & 218,83 & 74,33 & 75,75 & 201,32 & 219,47 & 124,33 & 31,34 & 869,61 & 294 & 1504 \\
\hline Füzérradvány & 363 & 216,80 & 39,08 & 41,23 & 148,22 & 137,51 & 121,38 & 103,49 & 766,48 & 621 & 2323 \\
\hline Füzvölgy & 132 & 196,85 & 69,71 & 107,73 & 124,85 & 280,48 & 186,11 & 69,50 & 927,50 & 164 & 988 \\
\hline Gáborjánháza & 80 & 190,43 & 28,43 & 46,39 & 142,98 & 220,58 & 164,79 & 39,32 & 786,53 & 563 & 2214 \\
\hline Gadács & 115 & 165,32 & 32,35 & 58,35 & 63,38 & 182,23 & 134,83 & 29,36 & 607,48 & 1012 & 2872 \\
\hline Gadány & 379 & 218,53 & 30,56 & 45,86 & 125,65 & 164,86 & 157,67 & 7,79 & 705,07 & 816 & 2631 \\
\hline Gadna & 285 & 280,79 & 21,37 & 9,26 & 38,90 & 66,61 & 135,66 & 10,00 & 553,33 & 1057 & 2919 \\
\hline Gagyapáti & 28 & 249,24 & 47,75 & 104,81 & 128,77 & 245,91 & 172,33 & 0,00 & 844,00 & 363 & 1737 \\
\hline Gagybátor & 215 & 197,70 & 34,95 & 43,41 & 89,52 & 170,23 & 114,79 & 21,40 & 628,59 & 989 & 2843 \\
\hline Gagyvendégi & 234 & 200,12 & 53,92 & 57,73 & 123,91 & 143,00 & 120,53 & 10,47 & 651,95 & 945 & 2798 \\
\hline Gálosfa & 320 & 218,39 & 78,66 & 96,54 & 100,33 & 198,38 & 172,28 & 25,32 & 793,36 & 533 & 2148 \\
\hline Galvács & 108 & 181,59 & 50,69 & 57,74 & 89,24 & 196,28 & 154,79 & 26,68 & 699,28 & 837 & 2657 \\
\hline Ganna & 315 & 204,31 & 79,22 & 141,60 & 184,81 & 244,74 & 174,97 & 59,12 & 947,18 & 136 & 830 \\
\hline Garáb & 60 & 172,00 & 78,57 & 77,58 & 307,23 & 204,04 & 178,25 & 115,43 & 1055,52 & 43 & 286 \\
\hline Garadna & 430 & 204,80 & 65,75 & 90,73 & 134,75 & 178,97 & 159,31 & 21,61 & 765,19 & 625 & 2333 \\
\hline
\end{tabular}




\begin{tabular}{|c|c|c|c|c|c|c|c|c|c|c|c|}
\hline Településnév & $\begin{array}{l}\text { Népesség- } \\
\text { szám, } 2010\end{array}$ & $\begin{array}{l}\text { Népes- } \\
\text { ség }\end{array}$ & $\begin{array}{l}\text { Társa- } \\
\text { dalom }\end{array}$ & $\begin{array}{l}\text { Társa- } \\
\text { dalom } \\
\text { (2011) }\end{array}$ & Ellátottság & Gazdaság & $\begin{array}{l}\text { Közle- } \\
\text { kedés }\end{array}$ & $\begin{array}{c}\text { Idegen- } \\
\text { forgalom }\end{array}$ & $\begin{array}{l}\text { Összfej- } \\
\text { lettség }\end{array}$ & $\begin{array}{c}\text { H. Apró- } \\
\text { falu }\end{array}$ & $\begin{array}{c}\text { H. Fal- } \\
\text { vak }\end{array}$ \\
\hline Garbolc & 151 & \begin{tabular}{l|l|}
266,37 & \\
\end{tabular} & \begin{tabular}{l|l|}
24,79 \\
\end{tabular} & 25,82 & \begin{tabular}{l|l}
93,36 \\
\end{tabular} & 194,05 & 80,65 & \begin{tabular}{l|l}
120,00 \\
\end{tabular} & 779,22 & 589 & 2264 \\
\hline Garé & 324 & 208,82 & \begin{tabular}{l|l|}
36,70 \\
\end{tabular} & \begin{tabular}{l|l|}
35,08 \\
\end{tabular} & \begin{tabular}{l|}
110,94 \\
\end{tabular} & 200,29 & 193,50 & \begin{tabular}{l|l|}
7,56 \\
\end{tabular} & 757,82 & 656 & 2389 \\
\hline Gasztony & 464 & \begin{tabular}{l|}
198,71 \\
\end{tabular} & 55,15 & 66,29 & 214,71 & \begin{tabular}{l|}
217,59 \\
\end{tabular} & \begin{tabular}{l|}
171,50 \\
\end{tabular} & \begin{tabular}{|l|}
33,61 \\
\end{tabular} & 891,26 & 240 & 1290 \\
\hline Gecse & 444 & 191,93 & \begin{tabular}{|l|}
41,62 \\
\end{tabular} & 51,05 & \begin{tabular}{l|}
102,71 \\
\end{tabular} & 229,18 & \begin{tabular}{|l|}
151,22 \\
\end{tabular} & \begin{tabular}{|l|}
17,61 \\
\end{tabular} & 734,26 & 736 & 2521 \\
\hline Gelsesziget & 271 & 231,40 & \begin{tabular}{|l|}
34,87 \\
\end{tabular} & \begin{tabular}{l|l}
42,02 \\
\end{tabular} & 143,16 & 231,52 & 184,77 & 12,29 & 838,02 & 382 & 1788 \\
\hline Gerényes & 260 & 220,10 & 33,61 & \begin{tabular}{l|l|}
36,74 \\
\end{tabular} & 118,23 & \begin{tabular}{l|}
102,00 \\
\end{tabular} & \begin{tabular}{l|}
167,67 \\
\end{tabular} & 18,85 & \begin{tabular}{l|l|}
660,47 \\
\end{tabular} & 924 & 2775 \\
\hline Gétye & 125 & \begin{tabular}{l|l}
190,95 \\
\end{tabular} & \begin{tabular}{l|l|}
32,14 \\
\end{tabular} & 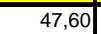 & \begin{tabular}{l|l}
81,80 \\
\end{tabular} & \begin{tabular}{l|}
197,36 \\
\end{tabular} & \begin{tabular}{l|l}
160,49 \\
\end{tabular} & 9,19 & 671,92 & 894 & 2741 \\
\hline Gic & 383 & 198,06 & 57,38 & 57,69 & 155,84 & 225,92 & 147,50 & 16,90 & 801,59 & 497 & 2080 \\
\hline Gige & 396 & 253,46 & 27,62 & 29,79 & 84,74 & 135,14 & 181,85 & 12,38 & 695,19 & 849 & 2672 \\
\hline Gilvánfa & 427 & 273,90 & \begin{tabular}{l|l|}
10,68 \\
\end{tabular} & 14,00 & \begin{tabular}{l|l}
46,11 \\
\end{tabular} & \begin{tabular}{l|l}
95,16 &
\end{tabular} & \begin{tabular}{l|}
161,47 \\
\end{tabular} & 5,74 & 593,05 & 1029 & 2889 \\
\hline Gombosszeg & 40 & 239,05 & 137,12 & 169,14 & 173,76 & 258,00 & 189,61 & 131,99 & 1129,52 & 19 & 134 \\
\hline Gór & 313 & 293,65 & 52,64 & 85,53 & 227,70 & 248,37 & 188,03 & 29,38 & 1039,77 & 56 & 342 \\
\hline Gordisa & 291 & 246,26 & 29,20 & 28,56 & 146,12 & 141,00 & 168,63 & 10,00 & 741,22 & 710 & 2478 \\
\hline Gosztola & 52 & 284,04 & 153,38 & 158,41 & 55,47 & 257,93 & 178,36 & 127,60 & 1056,78 & 41 & 279 \\
\hline Gömörszölös & 80 & 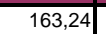 & 85,50 & 98,72 & 99,71 & |191,13 & 142,28 & 110,36 & 792,22 & 536 & 2159 \\
\hline Görcsönydoboka & 417 & 195,76 & 123,18 & 118,96 & 155,88 & 237,17 & 168,16 & 45,61 & 925,76 & 169 & 1006 \\
\hline Gösfa & 320 & 195,31 & 44,17 & 51,77 & 145,86 & 225,67 & 192,55 & 38,40 & 841,96 & 367 & 1753 \\
\hline Grábóc & 191 & 186,46 & 29,99 & 58,96 & 82,93 & | & 190,91 & 29,70 & 698,51 & 839 & 2661 \\
\hline Gyalóka & 80 & 234,89 & 76,20 & 80,04 & 173,71 & 216,66 & 102,85 & 0,00 & 804,31 & 491 & 2060 \\
\hline Gyanógeregye & 164 & 213,97 & 44,22 & 64,60 & 206,76 & 238,74 & 173,63 & 19,46 & 896,79 & 225 & 1251 \\
\hline Gyepükaján & 381 & 217,18 & 37,33 & 30,80 & 122,59 & 177,89 & 175,34 & 17,89 & 748,23 & 690 & 2439 \\
\hline Gyód & 691 & 273,99 & 59,23 & 86,45 & 160,10 & 226,56 & 204,09 & 18,79 & 942,76 & 142 & 859 \\
\hline Gyóró & 387 & 207,59 & 28,49 & 40,16 & 149,16 & 253,22 & 165,22 & 35,33 & 839,02 & 376 & 1778 \\
\hline Gyöngyfa & 158 & 243,50 & 23,92 & 25,94 & 109,35 & 96,84 & 174,34 & 15,51 & 663,46 & 915 & 2765 \\
\hline Gyöngyösmellék & 327 & \begin{tabular}{l|l|}
220,45 \\
\end{tabular} & \begin{tabular}{l|l|}
20,66 \\
\end{tabular} & 26,23 & \begin{tabular}{l|l|}
86,62 \\
\end{tabular} & 120,88 & 151,37 & 14,99 & |614,97 & 1002 & 2862 \\
\hline Györöcske & 139 & 236,31 & 20,09 & 46,82 & 139,11 & 213,56 & 171,23 & 37,63 & 817,93 & 440 & 1954 \\
\hline Gyugy & 296 & 222,74 & 32,30 & 43,27 & \begin{tabular}{l|l|}
100,88 \\
\end{tabular} & 183,36 & 170,46 & 38,28 & 748,02 & 692 & 2442 \\
\hline Gyügye & 255 & |181,53 & 40,51 & 57,42 & 224,69 & 287,82 & 150,15 & 29,61 & 914,32 & 194 & 1114 \\
\hline Gyürüs & 96 & 200,15 & 68,35 & 55,33 & 135,05 & 178,23 & 164,53 & 5,40 & 751,71 & 678 & 2423 \\
\hline Hács & 421 & 202,37 & 40,54 & 45,75 & 130,07 & 134,75 & 173,81 & 5,82 & 687,36 & 864 & 2696 \\
\hline Hagyárosbörönd & 319 & 230,95 & 66,73 & 88,32 & 115,63 & 247,58 & 201,93 & 32,78 & 895,61 & 229 & 1263 \\
\hline Hajmás & 247 & 220,96 & 26,31 & 31,37 & 115,98 & 144,21 & 158,60 & 9,92 & 675,99 & 887 & 2727 \\
\hline Halastó & 109 & 154,02 & 22,55 & 37,82 & \begin{tabular}{l|l}
147,44 \\
\end{tabular} & \begin{tabular}{l|l}
257,72 \\
\end{tabular} & 188,76 & 34,38 & 804,87 & 486 & 2050 \\
\hline Halogy & 292 & 187,78 & 34,40 & 48,50 & 120,16 & 222,18 & 179,00 & 26,95 & 770,47 & 611 & 2305 \\
\hline Harasztifalu & 166 & 184,49 & 62,16 & 71,00 & 188,60 & 243,18 & 192,91 & 45,44 & 916,78 & 190 & 1091 \\
\hline Háromhuta & 149 & 182,60 & 20,76 & 45,16 & 176,78 & 243,02 & 115,50 & 149,35 & 888,00 & 251 & 1322 \\
\hline Hásságy & 299 & 219,07 & 123,68 & 148,25 & 180,53 & 253,78 & 175,44 & 17,24 & 969,74 & 111 & 696 \\
\hline Hedrehely & 468 & 189,44 & 46,78 & 53,55 & \begin{tabular}{l|l}
110,83 \\
\end{tabular} & 114,39 & 188,05 & 10,98 & 660,47 & 925 & 2776 \\
\hline Hegyesd & 187 & 223,74 & 91,48 & 119,42 & 216,81 & 223,64 & 182,98 & 44,72 & 983,36 & 97 & 613 \\
\hline Hegyháthodász & 176 & 206,34 & 70,25 & 81,88 & 122,67 & 239,86 & 179,71 & 36,17 & 855,01 & 324 & 1638 \\
\hline Hegyhátmaróc & 173 & 159,65 & 52,50 & 62,33 & 155,75 & 207,10 & 143,65 & 20,59 & 739,24 & 716 & 2491 \\
\hline Hegyhátsál & 160 & 187,81 & 30,50 & 70,49 & 127,27 & 260,58 & 198,00 & 25,24 & 829,40 & 406 & 1871 \\
\hline Hegyhátszentjakab & 293 & 199,11 & 81,57 & 84,64 & 286,52 & 238,75 & 175,99 & 243,19 & 1225,14 & 10 & 60 \\
\hline Hegyhátszentmárton & 64 & 181,87 & 45,69 & 64,45 & 184,94 & 241,48 & 167,91 & 48,75 & 870,63 & 290 & 1493 \\
\hline Hegyhátszentpéter & 158 & 171,75 & 35,47 & 51,83 & 154,11 & 221,95 & 186,93 & 9,38 & 779,58 & 588 & 2263 \\
\hline Hegymagas & 308 & 234,42 & 84,40 & 116,24 & 235,30 & 231,17 & 186,70 & 94,09 & 1066,08 & 37 & 253 \\
\hline Hegymeg & 129 & 204,18 & 38,28 & 62,17 & $\begin{array}{ll}156,69 \\
\end{array}$ & \begin{tabular}{l|l}
168,46 \\
\end{tabular} & 178,45 & 19,00 & 765,05 & 628 & 2336 \\
\hline Hegyszentmárton & 451 & 200,50 & 44,58 & 53,57 & \begin{tabular}{|l|}
151,63 \\
\end{tabular} & 182,65 & 159,78 & 26,30 & 765,44 & 624 & 2331 \\
\hline Hejce & 275 & 199,41 & 55,95 & 71,55 & 85,57 & 202,93 & 152,35 & 62,27 & 758,48 & 651 & 2383 \\
\hline Hejökürt & 306 & 207,65 & 28,62 & 48,77 & 134,73 & 199,92 & 192,87 & 8,01 & 771,80 & 608 & 2298 \\
\hline Hencse & 355 & 214,53 & 47,83 & 53,62 & 112,14 & \begin{tabular}{l|l|}
156,02 \\
\end{tabular} & 203,53 & 62,18 & 796,24 & 521 & 2128 \\
\hline Heresznye & 298 & 203,47 & 22,69 & 57,33 & 218,89 & 158,95 & $\begin{array}{ll}119,88 \\
\end{array}$ & 18,22 & 742,10 & 707 & 2475 \\
\hline Hermánszeg & 277 & 188,20 & 28,96 & 35,42 & 145,33 & 235,98 & 113,94 & 28,85 & 741,26 & 709 & 2477 \\
\hline Hernádbűd & 155 & 217,83 & 42,60 & 52,25 & 135,54 & 160,08 & 169,53 & 10,00 & 735,58 & 731 & 2513 \\
\hline Hernádcéce & 208 & 183,21 & 60,30 & 56,74 & 75,98 & 103,95 & 141,53 & 20,00 & 584,97 & 1037 & 2898 \\
\hline Hernádkércs & 323 & 179,05 & 65,35 & 75,59 & 219,12 & 205,80 & 176,10 & 25,18 & 870,60 & 291 & 1494 \\
\hline Hernádpetri & 256 & 304,00 & 40,09 & 39,02 & 31,29 & 105,84 & 134,84 & 9,57 & 625,64 & 990 & 2847 \\
\hline Hernádszentandrás & 456 & 260,84 & 33,63 & 37,14 & 116,14 & 102,92 & 173,76 & 0,00 & 687,28 & 865 & 2697 \\
\hline Hernádszurdok & 207 & 183,77 & 54,52 & 56,98 & 98,03 & 139,80 & 161,34 & 15,10 & \begin{tabular}{l|l}
652,56 \\
\end{tabular} & 944 & 2797 \\
\hline Hernyék & 113 & 211,75 & \begin{tabular}{|l|}
18,96 \\
\end{tabular} & 18,33 & 86,05 & 163,09 & 180,73 & 39,06 & 699,64 & 835 & 2655 \\
\hline Hetefejércse & 301 & 225,51 & 18,91 & 28,36 & 144,03 & 188,43 & 135,07 & 20,00 & 731,96 & 742 & 2528 \\
\hline Hetyefö & 93 & 183,78 & 61,85 & 55,07 & 121,53 & 201,44 & 154,80 & 3,76 & 727,17 & 755 & 2546 \\
\hline Hidegkút & 445 & 261,06 & 66,19 & 127,03 & 187,15 & 249,13 & 197,94 & 47,13 & 1008,60 & 78 & 479 \\
\hline Hidegség & 369 & 294,08 & 87,52 & 119,19 & 195,61 & 254,45 & 171,89 & 97,83 & 1101,37 & 25 & 176 \\
\hline Hirics & 248 & \begin{tabular}{l|l|}
221,78 \\
\end{tabular} & 7,61 & 9,16 & 124,64 & 82,05 & 147,32 & 29,77 & 613,16 & 1004 & 2864 \\
\hline Hollád & 273 & 178,19 & \begin{tabular}{|l|}
32,37 \\
\end{tabular} & \begin{tabular}{l|l|}
42,66 \\
\end{tabular} & 145,38 & |122,13 & 141,68 & 20,00 & 639,74 & 972 & 2825 \\
\hline Hollókö & 364 & 204,42 & 74,84 & 103,80 & 301,07 & 235,96 & 166,80 & 287,52 & 1270,61 & 7 & 37 \\
\hline Homokkomárom & 225 & 206,03 & 90,10 & 80,64 & 91,51 & 195,59 & 169,74 & 33,93 & 786,90 & 559 & 2209 \\
\hline Horpács & 176 & 197,69 & 74,77 & 95,13 & 189,62 & 224,66 & 158,66 & 74,18 & 919,59 & 180 & 1060 \\
\hline Horváthertelend & 80 & 191,79 & 11,43 & 6,24 & 72,88 & 114,99 & 150,25 & 14,47 & 555,81 & 1056 & 2918 \\
\hline Horvátlövö & 220 & 245,82 & $\begin{array}{ll}115,02 \\
\end{array}$ & 154,73 & 164,71 & 250,99 & \begin{tabular}{ll|}
187,66 \\
\end{tabular} & 38,06 & 1002,25 & 87 & 514 \\
\hline
\end{tabular}




\begin{tabular}{|c|c|c|c|c|c|c|c|c|c|c|c|}
\hline Településnév & $\begin{array}{l}\text { Népesség- } \\
\text { szám, } 2010\end{array}$ & $\begin{array}{l}\text { Népes- } \\
\text { ség }\end{array}$ & $\begin{array}{l}\text { Társa- } \\
\text { dalom }\end{array}$ & $\begin{array}{l}\text { Társa- } \\
\text { dalom } \\
(2011)\end{array}$ & Ellátottság & Gazdaság & $\begin{array}{l}\text { Közle- } \\
\text { kedés }\end{array}$ & $\begin{array}{l}\text { Idegen- } \\
\text { forgalom }\end{array}$ & $\begin{array}{l}\text { Összfej- } \\
\text { lettség }\end{array}$ & $\begin{array}{c}\text { H. Apró- } \\
\text { falu }\end{array}$ & $\begin{array}{c}\text { H. Fal- } \\
\text { vak }\end{array}$ \\
\hline Hosszúvíz & 53 & 174,96 & 87,07 & 98,05 & 149,65 & 236,35 & 156,30 & 0,00 & 804,33 & 490 & 2059 \\
\hline Hosszúvölgy & 183 & 218,73 & 57,25 & 83,76 & 178,93 & 210,93 & 179,96 & 2,02 & 847,83 & 348 & 1701 \\
\hline Hosztót & 82 & 170,13 & 28,60 & 47,75 & 232,07 & 226,06 & 160,13 & 31,01 & 848,00 & 345 & 1697 \\
\hline Hottó & 354 & 241,22 & 60,61 & 85,01 & 198,06 & 245,22 & 208,46 & 25,49 & 979,05 & 103 & 644 \\
\hline Hövej & 327 & 236,16 & 36,66 & 61,92 & 199,23 & 234,23 & 186,66 & 27,50 & 920,43 & 179 & 1055 \\
\hline Hunyadfalva & 236 & 201,11 & 27,73 & 29,07 & 117,11 & 134,60 & 145,20 & 10,39 & 636,14 & 980 & 2834 \\
\hline Husztót & 72 & 194,49 & 63,39 & 80,35 & 53,13 & 185,30 & 170,33 & 10,00 & 676,63 & 885 & 2724 \\
\hline Ibafa & 243 & 227,16 & 62,25 & 90,18 & 85,74 & 92,92 & 148,10 & 81,17 & 697,35 & 842 & 2665 \\
\hline Iborfia & 13 & 145,67 & 0,00 & 10,71 & 172,66 & 324,26 & 157,45 & 0,00 & 800,05 & 504 & 2093 \\
\hline Iklanberény & 51 & 204,84 & 43,72 & 101,67 & 150,78 & 214,35 & 186,35 & 0,00 & 800,04 & 505 & 2094 \\
\hline |klódbördöce & 321 & 190,15 & 48,28 & 57,65 & 165,78 & 211,08 & 183,99 & 15,06 & 814,34 & 455 & 1983 \\
\hline Iliny & 184 & 187,09 & 32,46 & 54,88 & 194,23 & 229,49 & 169,27 & 13,32 & 825,87 & 414 & 1889 \\
\hline Illocska & 249 & 197,93 & 8,78 & 24,79 & 79,41 & 185,06 & 138,91 & 9,84 & 619,94 & 996 & 2854 \\
\hline Imola & 100 & 159,92 & 66,99 & 65,88 & 179,77 & 210,42 & 127,86 & 54,51 & 799,45 & 508 & 2099 \\
\hline Ipacsfa & 228 & 210,72 & 27,94 & 38,94 & 100,35 & 225,06 & 191,51 & 28,40 & 783,98 & 575 & 2234 \\
\hline |polydamásd & 387 & 210,71 & 42,69 & 55,23 & 199,97 & 207,11 & 156,12 & 37,19 & 853,78 & 328 & 1649 \\
\hline Ipolytarnóc & 498 & 206,42 & 53,77 & 56,71 & 175,36 & 163,27 & 141,19 & 33,05 & $\begin{array}{l}773,07 \\
\end{array}$ & 602 & 2290 \\
\hline Ipolytölgyes & 328 & 247,04 & 63,84 & 70,83 & 147,18 & 226,77 & 133,53 & 37,06 & 855,42 & 323 & 1635 \\
\hline Irota & 90 & 136,02 & 93,26 & 180,87 & 45,92 & 225,43 & 162,23 & 48,62 & 711,48 & 802 & 2609 \\
\hline Ispánk & 109 & 220,57 & 213,26 & 217,91 & 207,36 & 249,56 & 190,08 & 41,71 & 1122,54 & 21 & 142 \\
\hline Iszkáz & 368 & 174,98 & 47,65 & 62,99 & 130,68 & 221,47 & 152,97 & 56,59 & 784,36 & 573 & 2231 \\
\hline Ivád & 404 & 187,57 & 39,56 & 53,54 & 176,51 & 186,45 & 201,88 & 24,27 & 816,25 & 447 & 1970 \\
\hline Ivánbattyán & 139 & 165,12 & 18,06 & 52,64 & 216,51 & 214,46 & 164,22 & 55,95 & 834,33 & 390 & 1828 \\
\hline Ivándárda & 252 & 197,72 & 40,04 & 56,33 & 107,77 & 251,35 & 151,71 & 9,73 & 758,32 & 654 & 2387 \\
\hline Jágónak & 246 & 177,18 & 17,08 & 27,86 & 144,16 & 160,20 & 148,12 & 9,96 & 656,71 & 939 & 2792 \\
\hline Jákfalva & 550 & 262,95 & 39,18 & 37,43 & 103,44 & 139,59 & 166,24 & 4,46 & 715,86 & 786 & 2589 \\
\hline Jászivány & 407 & 195,27 & 49,34 & 64,57 & 169,47 & 227,92 & 135,70 & 38,67 & 816,36 & 446 & 1968 \\
\hline Jósvafö & 320 & 181,94 & 105,64 & 118,59 & 219,34 & 237,72 & 116,65 & 182,98 & 1044,27 & 51 & 319 \\
\hline Kacorlak & 230 & 214,05 & 30,94 & 61,27 & 146,55 & 232,56 & 180,20 & 4,63 & 808,93 & 471 & 2024 \\
\hline Kacsóta & 283 & 214,92 & 38,45 & 39,42 & 91,11 & 193,61 & 219,19 & 8,66 & 765,95 & 622 & 2325 \\
\hline Kákics & 236 & 218,23 & 20,43 & 19,37 & 51,17 & 98,00 & 181,17 & 27,45 & 596,46 & 1024 & 2884 \\
\hline Kalaznó & 196 & 185,24 & 41,24 & 44,06 & 125,07 & 144,50 & 152,63 & 12,51 & 661,19 & 921 & 2772 \\
\hline Kallósd & 88 & 149,89 & 26,73 & 41,58 & 160,11 & 279,95 & 183,80 & 49,22 & 849,70 & 340 & 1680 \\
\hline Kálócfa & 174 & 169,64 & 41,14 & 50,98 & 248,47 & 237,80 & 174,40 & 24,08 & 895,52 & 230 & 1264 \\
\hline Kám & 429 & 197,12 & 73,07 & 83,61 & 263,75 & 247,70 & 195,18 & 37,42 & 1014,24 & 73 & 447 \\
\hline Kamond & 446 & 196,27 & 25,10 & 36,59 & 168,01 & 206,94 & 122,76 & 39,81 & 758,88 & 647 & 2378 \\
\hline Kánó & 175 & 175,97 & 39,70 & 56,02 & 80,79 & 221,17 & 146,51 & 14,01 & 678,14 & 882 & 2718 \\
\hline Kány & 61 & 148,89 & 52,62 & 43,73 & 55,39 & 220,76 & 118,28 & 0,00 & 595,95 & 1025 & 2885 \\
\hline Kánya & 467 & 190,40 & 68,92 & 73,70 & 148,42 & 230,29 & 171,21 & 5,25 & 814,49 & 454 & 1982 \\
\hline Kányavár & 135 & 158,50 & 33,04 & 35,69 & 185,23 & 217,86 & 164,79 & 37,24 & 796,67 & 517 & 2120 \\
\hline Kapolcs & 401 & 196,19 & 85,80 & 105,03 & 254,08 & 240,82 & 185,91 & 119,44 & 1082,23 & 29 & 207 \\
\hline Kaposgyarmat & 109 & 166,00 & 63,53 & 63,51 & 101,19 & 208,08 & 174,45 & 82,16 & 795,42 & 525 & 2134 \\
\hline Kaposhomok & 505 & 265,35 & 43,46 & 47,93 & 76,64 & 115,70 & 199,27 & 24,56 & 724,98 & 763 & 2558 \\
\hline Kaposkeresztúr & 351 & 200,44 & 31,78 & 45,53 & 73,80 & 119,91 & 161,29 & 10,00 & 597,21 & 1023 & 2883 \\
\hline Káptalantóti & 477 & 223,58 & 67,67 & 86,55 & 154,83 & 255,81 & 183,04 & 84,75 & 969,68 & 112 & 697 \\
\hline Kára & 67 & 168,22 & 66,34 & 78,87 & 124,68 & 230,77 & 163,32 & 36,58 & 789,91 & 547 & 2184 \\
\hline Karakó & 215 & 172,21 & 35,17 & 40,52 & 142,45 & 218,65 & 151,26 & 9,69 & 729,43 & 749 & 2538 \\
\hline Karakószörcsök & 318 & 206,35 & 48,31 & 49,39 & 166,22 & 204,42 & 150,33 & 14,21 & 789,84 & 548 & 2185 \\
\hline Kárász & 355 & 185,16 & 81,48 & 97,41 & 207,67 & 222,89 & 180,17 & 47,95 & 925,33 & 170 & 1009 \\
\hline Karos & 533 & 234,28 & 55,42 & 62,75 & 170,96 & 178,33 & 117,39 & 4,60 & 760,97 & 641 & 2365 \\
\hline Kásád & 334 & 174,92 & 80,44 & 97,56 & 112,10 & 168,35 & 151,42 & 48,24 & 735,46 & 732 & 2514 \\
\hline Kastélyosdombó & 233 & 153,96 & 42,73 & 72,74 & 121,18 & 95,38 & 147,39 & 46,33 & 606,98 & 1014 & 2874 \\
\hline Kaszó & 127 & 184,41 & 98,05 & 80,69 & 181,10 & 237,88 & 147,35 & 138,60 & 987,38 & 96 & 595 \\
\hline Katádfa & 183 & 239,32 & 12,60 & 10,24 & 125,64 & 121,44 & 182,82 & 13,39 & 695,21 & 847 & 2670 \\
\hline Katafa & 375 & 224,31 & 47,23 & 66,98 & 167,31 & 243,13 & 202,04 & 20,10 & 904,13 & 210 & 1194 \\
\hline Kátoly & 345 & 193,70 & 104,41 & 86,42 & 139,76 & 203,21 & 185,34 & 19,72 & 846,14 & 354 & 1716 \\
\hline Kávás & 265 & 240,03 & 69,72 & 86,46 & 142,80 & 234,41 & 199,56 & 31,50 & 918,03 & 187 & 1078 \\
\hline Kazsok & 341 & 210,25 & 24,92 & 32,10 & 138,41 & 177,69 & 138,89 & 7,19 & 697,34 & 843 & 2666 \\
\hline Kéked & 231 & 180,54 & 51,85 & 54,92 & 141,92 & 172,60 & 142,85 & 148,92 & 838,67 & 378 & 1781 \\
\hline Kékesd & 184 & 190,27 & 50,95 & 54,24 & 120,56 & 209,03 & 202,80 & 31,18 & 804,80 & 487 & 2052 \\
\hline Kékkút & 98 & 289,37 & 75,21 & 115,85 & 225,20 & 255,39 & 179,58 & 60,68 & 1085,43 & 27 & 201 \\
\hline Keléd & 79 & 145,25 & 31,87 & 25,86 & 147,88 & 193,89 & 141,48 & 5,86 & 666,23 & 907 & 2755 \\
\hline Kéleshalom & 456 & 183,94 & 23,53 & 31,79 & 94,91 & 184,36 & 141,79 & 15,37 & 643,91 & 961 & 2814 \\
\hline Kelevíz & 357 & 212,04 & 55,19 & 58,98 & 64,25 & 196,10 & 182,93 & 29,90 & 740,41 & 713 & 2483 \\
\hline Kemeneskápolna & 99 & 153,31 & 57,48 & 76,83 & 109,32 & 232,20 & 190,59 & 14,82 & 757,72 & 657 & 2390 \\
\hline Kemenespálfa & 450 & 208,58 & 23,20 & 25,72 & 117,88 & 226,37 & 165,50 & 9,87 & 751,41 & 682 & 2427 \\
\hline Kemenesszentmárton & 218 & 204,58 & 52,27 & 65,08 & 150,51 & 237,33 & 192,33 & 40,97 & 877,99 & 275 & 1427 \\
\hline Keménfa & 99 & 185,74 & 17,02 & 29,10 & 169,23 & 188,22 & 169,22 & 11,22 & 740,66 & 712 & 2482 \\
\hline Kemestaródfa & 244 & 219,79 & 69,60 & 75,85 & 137,87 & 241,43 & 199,70 & 76,23 & 944,62 & 140 & 851 \\
\hline Kemse & 63 & 185,55 & 32,98 & 29,32 & 81,34 & 168,32 & 160,74 & 10,00 & 638,92 & 974 & 2828 \\
\hline Kenéz & 276 & 208,61 & 28,48 & 39,96 & 134,17 & 238,71 & 189,82 & 22,69 & 822,46 & 423 & 1911 \\
\hline
\end{tabular}




\begin{tabular}{|c|c|c|c|c|c|c|c|c|c|c|c|}
\hline Településnév & $\begin{array}{l}\text { Népesség- } \\
\text { szám, } 2010\end{array}$ & $\begin{array}{l}\text { Népes- } \\
\text { ség }\end{array}$ & $\begin{array}{l}\text { Társa- } \\
\text { dalom }\end{array}$ & $\begin{array}{l}\text { Társa- } \\
\text { dalom } \\
(2011) \\
\end{array}$ & Ellátottság & Gazdaság & $\begin{array}{l}\text { Közle- } \\
\text { kedés }\end{array}$ & $\begin{array}{c}\text { Idegen- } \\
\text { forgalom }\end{array}$ & $\begin{array}{l}\text { Összfej- } \\
\text { lettség }\end{array}$ & $\begin{array}{c}\begin{array}{c}\text { H. Apró- } \\
\text { falu }\end{array} \\
\end{array}$ & $\begin{array}{c}\begin{array}{c}\text { H. Fal- } \\
\text { vak }\end{array} \\
\end{array}$ \\
\hline Kercaszomor & 246 & 193,09 & 86,32 & 106,09 & 157,09 & 233,40 & 165,75 & 69,83 & 905,49 & 208 & 1187 \\
\hline Kercseliget & 474 & 207,20 & 23,23 & 21,89 & 99,77 & 69,37 & 139,97 & 25,51 & 565,05 & 1049 & 2911 \\
\hline Kerecseny & 266 & 223,97 & 24,58 & 29,67 & 147,34 & 185,92 & 156,18 & 13,57 & 751,56 & 680 & 2425 \\
\hline Keresztéte & 74 & 318,95 & 15,99 & 93,63 & 29,43 & 179,81 & 108,38 & 8,78 & 661,32 & 919 & 2770 \\
\hline Kerkabarabás & 294 & 207,03 & 38,97 & 52,24 & 154,29 & 194,51 & 180,03 & 28,74 & 803,57 & 495 & 2068 \\
\hline Kerkafalva & 117 & 185,26 & 69,11 & 68,72 & 131,45 & 236,96 & 160,33 & 109,04 & 892,15 & 236 & 1284 \\
\hline Kerkakutas & 151 & 200,50 & 31,61 & 53,50 & 109,06 & 250,68 & 158,62 & 15,33 & 765,79 & 623 & 2326 \\
\hline Kerkáskápolna & 90 & 202,09 & 71,75 & 102,61 & 92,01 & 242,72 & 164,03 & 41,35 & 813,94 & 458 & 1988 \\
\hline Kerkaszentkirály & 261 & 196,18 & 48,87 & 51,74 & 231,38 & 216,93 & 147,70 & 76,80 & 917,85 & 188 & 1079 \\
\hline Kerkateskánd & 173 & 207,30 & 25,18 & 44,24 & 165,08 & 210,88 & 184,55 & 48,32 & 841,31 & 370 & 1762 \\
\hline Kérsemjén & 327 & 204,52 & 35,96 & 38,77 & 106,64 & 171,22 & 150,04 & 24,99 & 693,38 & 855 & 2680 \\
\hline Kertészsziget & 417 & 190,98 & 32,86 & 27,66 & 162,46 & 165,41 & 135,78 & 5,88 & 693,37 & 856 & 2681 \\
\hline Keszőhidegkút & 229 & 184,14 & 64,30 & 118,48 & 104,83 & 175,67 & 150,67 & 16,92 & 696,52 & 844 & 2667 \\
\hline Kétbodony & 480 & 195,18 & 58,91 & 73,27 & 203,62 & 244,09 & 153,12 & 66,20 & 921,11 & 177 & 1048 \\
\hline Kétvölgy & 130 & 186,12 & 164,03 & 144,82 & 80,40 & 247,16 & 159,85 & 168,01 & 1005,57 & 83 & 496 \\
\hline Kilimán & 261 & 197,38 & 22,71 & 35,01 & 109,18 & 197,99 & 160,08 & 15,78 & 703,13 & 825 & 2642 \\
\hline Királyszentistván & 506 & 289,72 & 79,98 & 95,09 & 163,75 & 232,89 & 215,56 & 23,49 & 1005,39 & 84 & 499 \\
\hline Kisapáti & 379 & 222,00 & 48,85 & 64,44 & 198,98 & 210,01 & 183,35 & 43,02 & 906,21 & 207 & 1181 \\
\hline Kisasszond & 184 & 244,05 & 21,25 & 34,00 & 96,66 & 190,66 & 173,68 & 0,00 & 726,31 & 758 & 2551 \\
\hline Kisasszonyfa & 208 & 211,05 & 53,03 & 57,93 & 69,38 & 133,72 & 166,08 & 11,78 & 645,05 & 957 & 2810 \\
\hline Kisbabot & 220 & 191,22 & 53,47 & 58,36 & 195,50 & 250,07 & 178,79 & 11,14 & 880,21 & 269 & 1404 \\
\hline Kisbágyon & 440 & 199,09 & 47,26 & 50,15 & 160,02 & 220,53 & 160,72 & 19,65 & 807,26 & 477 & 2036 \\
\hline Kisbajom & 436 & 214,95 & 41,27 & 46,01 & 132,77 & 104,68 & 151,10 & 5,62 & 650,39 & 950 & 2803 \\
\hline Kisbárapáti & 455 & 174,78 & 66,67 & 70,37 & 154,83 & 176,74 & 134,41 & 5,39 & 712,81 & 799 & 2604 \\
\hline Kisbárkány & 226 & 186,40 & 42,16 & 48,32 & 163,57 & 208,38 & 181,76 & 10,85 & 793,12 & 534 & 2151 \\
\hline Kisberény & 186 & 234,30 & 51,02 & 50,56 & 117,82 & 83,76 & 180,11 & 0,00 & 667,02 & 903 & 2751 \\
\hline Kisberzseny & 109 & 190,04 & 19,07 & 38,44 & 106,62 & 201,39 & 142,03 & 7,65 & 666,78 & 905 & 2753 \\
\hline Kisbeszterce & 91 & 185,51 & 9,82 & 12,51 & 77,31 & 61,79 & 162,68 & 0,00 & 497,13 & 1071 & 2934 \\
\hline Kisbodak & 370 & 230,46 & 78,90 & 98,73 & 179,80 & 245,19 & 176,30 & 19,87 & 930,52 & 160 & 963 \\
\hline Kisbucsa & 452 & 221,75 & 53,90 & 67,00 & 157,74 & 221,11 & 227,67 & 15,91 & 898,06 & 222 & 1244 \\
\hline Kisbudmér & 117 & 196,18 & 73,20 & 57,17 & 105,81 & 207,39 & 160,67 & 52,23 & 795,48 & 524 & 2132 \\
\hline Kiscsécs & 210 & 255,88 & 7,52 & 9,43 & 35,22 & 59,93 & 160,28 & 0,00 & 518,83 & 1068 & 2931 \\
\hline Kiscsehi & 173 & 170,76 & 22,49 & 47,90 & 162,20 & 226,93 & 165,55 & 26,16 & 774,09 & 598 & 2284 \\
\hline Kiscsősz & 138 & 211,58 & 54,90 & 53,05 & 159,32 & 223,46 & 130,98 & 119,31 & 899,54 & 220 & 1234 \\
\hline Kisdér & 131 & 197,35 & 49,65 & 47,76 & 94,19 & 231,26 & 167,46 & 56,13 & 796,04 & 522 & 2130 \\
\hline Kisdobsza & 246 & 193,69 & 67,17 & 67,62 & 91,13 & 186,14 & 177,30 & 24,26 & 739,68 & 714 & 2487 \\
\hline Kisecset & 183 & 171,30 & 40,35 & 64,41 & 82,39 & 207,07 & 137,82 & 22,33 & 661,26 & 920 & 2771 \\
\hline Kisfüzes & 159 & 174,39 & 62,70 & 67,42 & 168,90 & 228,02 & 193,35 & 20,19 & 847,56 & 351 & 1708 \\
\hline Kisgörbö & 194 & 190,54 & 53,19 & 58,96 & 119,78 & 190,22 & 179,49 & 4,44 & 737,65 & 722 & 2501 \\
\hline Kisgyalán & 213 & 163,98 & 67,47 & 65,72 & 115,74 & 262,27 & 164,69 & 34,52 & 808,68 & 472 & 2026 \\
\hline Kishajmás & 242 & 222,15 & 14,99 & 23,31 & 64,04 & 128,39 & 177,94 & 14,34 & 621,85 & 995 & 2853 \\
\hline Kisherend & 208 & 195,18 & 28,53 & 44,68 & 152,33 & 210,37 & 174,74 & 11,78 & 772,93 & 604 & 2292 \\
\hline Kishódos & 89 & 235,74 & 13,71 & 19,82 & 69,91 & 135,96 & 75,84 & 20,00 & 551,16 & 1059 & 2921 \\
\hline Kishuta & 320 & 173,45 & 53,95 & 93,91 & 156,45 & 207,30 & 120,07 & 140,64 & 851,87 & 333 & 1664 \\
\hline Kisjakabfalva & 166 & 174,03 & 15,85 & 71,21 & 172,38 & 172,27 & 163,40 & 36,78 & 734,71 & 734 & 2518 \\
\hline Kiskassa & 279 & 181,20 & 35,22 & 90,51 & 141,94 & 209,36 & 177,58 & 26,83 & 772,12 & 607 & 2296 \\
\hline Kiskinizs & 359 & 233,68 & 54,94 & 53,69 & 145,67 & 164,45 & 179,40 & 20,48 & 798,61 & 511 & 2106 \\
\hline Kiskutas & 193 & 196,53 & 93,30 & 112,10 & 193,10 & 255,07 & 207,55 & 148,75 & 1094,31 & 26 & 185 \\
\hline Kislippó & 289 & 194,31 & 33,41 & 40,75 & 85,96 & 201,55 & 154,08 & 35,44 & 704,76 & 817 & 2633 \\
\hline Kismányok & 366 & 207,27 & 50,75 & 59,49 & 173,86 & 230,17 & 203,24 & 27,71 & 892,99 & 233 & 1277 \\
\hline Kisnyárád & 209 & 180,67 & 95,94 & 101,00 & 53,54 & 156,90 & 177,15 & 10,85 & 675,05 & 890 & 2731 \\
\hline Kispalád & 594 & 257,34 & 18,63 & 24,52 & 61,07 & 97,23 & 89,44 & 38,25 & 561,95 & 1052 & 2914 \\
\hline Kispáli & 283 & 274,95 & 44,33 & 73,33 & 205,81 & 253,08 & 217,88 & 10,13 & 1006,18 & 81 & 492 \\
\hline Kispirit & 98 & 181,27 & 42,84 & 37,99 & 113,18 & 201,20 & 113,87 & 8,50 & 660,87 & 922 & 2773 \\
\hline Kisrákos & 224 & 180,77 & 55,93 & 62,42 & 143,87 & 253,14 & 178,69 & 40,64 & 853,03 & 330 & 1654 \\
\hline Kisrécse & 194 & 251,91 & 53,12 & 69,59 & 83,55 & 206,53 & 167,59 & 36,85 & 799,55 & 506 & 2097 \\
\hline Kisrozvágy & 195 & 170,85 & 49,18 & 65,06 & 159,79 & 171,46 & 109,69 & 12,57 & 673,54 & 893 & 2735 \\
\hline Kissikátor & 345 & 200,89 & 36,00 & 44,83 & 105,82 & 209,35 & 134,84 & 17,10 & 703,99 & 822 & 2638 \\
\hline Kissomlyó & 251 & 199,61 & 63,06 & 89,89 & 140,23 & 213,99 & 161,91 & 28,39 & 807,19 & 478 & 2037 \\
\hline Kisszékely & 351 & 155,70 & 24,58 & 34,52 & 144,13 & 199,84 & 127,28 & 30,43 & 681,96 & 878 & 2712 \\
\hline Kisszentmárton & 292 & 225,29 & 11,77 & 16,21 & 141,69 & 108,36 & 145,50 & 26,79 & 659,41 & 928 & 2780 \\
\hline Kissziget & 195 & 194,46 & 16,34 & 19,72 & 158,26 & 198,45 & 173,93 & 18,50 & 759,95 & 644 & 2369 \\
\hline Kisszölös & 150 & 239,99 & 29,96 & 27,04 & 96,26 & 92,91 & 135,62 & 30,04 & 624,79 & 991 & 2848 \\
\hline Kistamási & 140 & 211,56 & 16,34 & 17,78 & 33,85 & 96,53 & 164,11 & 0,00 & 522,38 & 1065 & 2928 \\
\hline Kistapolca & 215 & 207,92 & 50,20 & 68,51 & 159,60 & 202,97 & 175,10 & 10,12 & 805,91 & 483 & 2046 \\
\hline Kistolmács & 186 & 223,49 & 18,31 & 26,49 & 149,83 & 146,50 & 168,03 & 72,39 & 778,56 & 593 & 2270 \\
\hline Kistormás & 357 & 195,36 & 27,16 & 36,34 & 117,82 & 202,63 & 156,82 & 14,91 & 714,71 & 794 & 2599 \\
\hline Kistótfalu & 334 & 203,43 & 39,58 & 54,82 & 117,03 & 209,76 & 184,07 & 27,60 & 781,47 & 581 & 2249 \\
\hline Kisunyom & 431 & 260,70 & 66,29 & 87,81 & 196,03 & 236,12 & 215,89 & 14,86 & 989,90 & 93 & 584 \\
\hline Kisvásárhely & 60 & 195,51 & 51,47 & 69,35 & 159,15 & 206,20 & 166,31 & 7,72 & 786,36 & 565 & 2217 \\
\hline Kisvaszar & 352 & 249,74 & 37,87 & 37,60 & 140,07 & 74,75 & 169,12 & 20,89 & 692,44 & 857 & 2682 \\
\hline
\end{tabular}




\begin{tabular}{|c|c|c|c|c|c|c|c|c|c|c|c|}
\hline Településnév & $\begin{array}{l}\text { Népesség- } \\
\text { szám, } 2010\end{array}$ & $\begin{array}{l}\text { Népes- } \\
\text { ség }\end{array}$ & $\begin{array}{l}\text { Társa- } \\
\text { dalom }\end{array}$ & $\begin{array}{l}\text { Társa- } \\
\text { dalom } \\
\text { (2011) }\end{array}$ & Ellátottság & Gazdaság & $\begin{array}{l}\text { Közle- } \\
\text { kedés }\end{array}$ & $\begin{array}{c}\text { Idegen- } \\
\text { forgalom }\end{array}$ & $\begin{array}{l}\text { Összfej- } \\
\text { lettség }\end{array}$ & $\begin{array}{c}\text { H. Apró- } \\
\text { falu }\end{array}$ & $\begin{array}{c}\text { H. Fal- } \\
\text { vak }\end{array}$ \\
\hline Kisvejke & 441 & 216,04 & 67,07 & 92,40 & 145,94 & 206,07 & 168,38 & 27,72 & 831,23 & 401 & 1857 \\
\hline Kiszsidány & 99 & 180,29 & 50,18 & 114,60 & 176,58 & 250,00 & 196,36 & 6,55 & 859,95 & 316 & 1586 \\
\hline Klárafalva & 532 & 228,67 & 35,33 & 50,89 & 183,07 & 204,30 & 200,64 & 9,21 & 861,23 & 313 & 1571 \\
\hline Komjáti & 261 & 160,62 & 51,54 & 67,18 & 126,87 & 195,22 & 112,48 & 29,39 & 676,12 & 886 & 2726 \\
\hline Komlódtótfalu & 129 & 242,96 & 24,92 & 61,98 & 102,41 & 190,85 & 135,50 & 29,00 & 725,65 & 759 & 2552 \\
\hline Komlósd & 184 & $\begin{array}{ll}181,62 \\
\end{array}$ & 27,67 & 34,43 & 196,01 & 171,15 & 154,78 & 23,32 & 754,55 & 666 & 2406 \\
\hline Komlóska & 314 & 172,65 & 96,99 & 139,87 & 223,27 & 259,56 & 144,45 & 62,31 & 959,24 & 120 & 759 \\
\hline Koppányszántó & 367 & 170,80 & 39,18 & 48,49 & 118,71 & 181,22 & 141,53 & 12,10 & 663,53 & 914 & 2764 \\
\hline Korlát & 328 & 215,64 & 43,99 & 46,02 & 102,22 & 120,83 & 140,36 & 44,95 & 667,98 & 902 & 2750 \\
\hline Kórós & 250 & 227,73 & 17,58 & \begin{tabular}{l|}
14,72 \\
\end{tabular} & \begin{tabular}{l|l|}
107,02 \\
\end{tabular} & 79,15 & 143,52 & 19,80 & 594,80 & 1027 & 2887 \\
\hline Kovácshida & 295 & 221,11 & 28,94 & 41,03 & $\begin{array}{ll}104,23 \\
\end{array}$ & $\begin{array}{ll}199,42 \\
\end{array}$ & $\begin{array}{ll}184,74 \\
\end{array}$ & 62,34 & \begin{tabular}{|l|}
800,77 \\
\end{tabular} & 502 & 2087 \\
\hline Kovácsszénája & 76 & 188,50 & 61,72 & 96,57 & 72,41 & 183,30 & 164,21 & 10,00 & 680,14 & 879 & 2713 \\
\hline Kozárd & 183 & 187,94 & 62,47 & 81,20 & 219,08 & 243,47 & 182,80 & 113,01 & 1008,76 & 77 & 477 \\
\hline Kozmadombja & 49 & 203,79 & 33,34 & 50,08 & 150,24 & 279,85 & 171,18 & 5,67 & 844,06 & 362 & 1735 \\
\hline Köblény & 247 & 179,13 & 32,89 & 41,30 & 144,45 & 182,85 & 151,72 & 9,92 & 700,95 & 829 & 2646 \\
\hline Köcsk & 288 & 195,67 & 25,78 & 43,15 & 172,06 & 228,66 & 172,02 & 12,03 & 806,21 & 482 & 2044 \\
\hline Kökény & 666 & 261,47 & 91,68 & 114,87 & 110,04 & 229,15 & 204,39 & 12,13 & 908,86 & 203 & 1158 \\
\hline Kőszegdoroszló & 249 & 217,84 & 65,10 & 72,29 & 149,48 & 228,81 & 215,77 & 49,62 & 926,62 & 165 & 999 \\
\hline Köszegpaty & 220 & 207,33 & 50,48 & 54,74 & 153,30 & 240,36 & 176,03 & 12,61 & 840,12 & 371 & 1766 \\
\hline Köszegszerdahely & 512 & 235,85 & 98,50 & 103,94 & 214,63 & 257,79 & 211,66 & 45,98 & 1064,41 & 38 & 257 \\
\hline Kövágótőttős & 377 & 256,74 & 35,25 & 58,36 & 147,67 & 158,02 & 192,29 & 49,50 & 839,46 & 374 & 1773 \\
\hline Kövegy & 428 & 183,91 & 30,50 & 36,49 & 155,94 & 196,78 & 148,38 & 5,73 & 721,22 & 772 & 2570 \\
\hline Köveskál & 409 & 197,27 & 89,36 & 104,11 & 192,31 & 207,17 & 177,12 & 94,45 & 957,68 & 122 & 768 \\
\hline Krasznokvajda & 540 & 214,93 & 74,61 & 64,79 & 159,95 & 121,59 & 127,03 & 38,60 & 736,71 & 728 & 2508 \\
\hline Kup & 495 & 228,00 & 49,37 & 69,65 & 174,48 & 225,71 & 179,84 & 28,71 & 886,10 & 255 & 1340 \\
\hline Kupa & 176 & 195,61 & 17,15 & 21,44 & 41,59 & 213,52 & 161,42 & 10,00 & 639,28 & 973 & 2826 \\
\hline Kutasó & 112 & 202,41 & 44,09 & 83,07 & 208,85 & 183,88 & 156,25 & 24,73 & 820,20 & 432 & 1933 \\
\hline Külsösárd & 83 & 163,17 & 42,14 & 20,28 & 221,28 & 235,58 & 190,17 & 10,60 & 862,95 & 310 & 1558 \\
\hline Lácacséke & 385 & 190,23 & 17,80 & 19,29 & 122,14 & 138,41 & 90,25 & 6,37 & 565,20 & 1048 & 2910 \\
\hline Ládbesenyő & 304 & 192,51 & 42,85 & 61,00 & 194,43 & 174,70 & 186,28 & 28,06 & 818,83 & 436 & 1945 \\
\hline Lakhegy & 468 & 213,50 & 52,87 & 65,32 & 186,96 & 245,46 & 199,27 & 19,67 & 917,74 & 189 & 1081 \\
\hline Lápafö & 182 & 173,64 & 29,12 & 33,75 & 108,67 & 165,37 & 128,88 & 0,00 & 605,69 & 1016 & 2876 \\
\hline Lapáncsa & 215 & 221,43 & 40,35 & 42,71 & 82,69 & 206,47 & 147,34 & 11,40 & 709,69 & 808 & 2617 \\
\hline Lasztonya & 119 & 262,21 & 13,75 & 17,88 & 80,88 & 127,81 & 145,77 & 9,49 & 639,91 & 971 & 2824 \\
\hline Legénd & 497 & 191,47 & 50,24 & 74,17 & 184,49 & 223,66 & 119,76 & 11,91 & 781,53 & 580 & 2248 \\
\hline Léh & 473 & 214,92 & 30,09 & 35,34 & 181,87 & 137,07 & 178,39 & 20,36 & 762,71 & 633 & 2353 \\
\hline Lénárddaróc & 309 & 170,96 & 44,72 & 46,82 & 202,70 & 199,88 & 162,43 & 0,00 & 780,68 & 584 & 2255 \\
\hline Lendvadedes & 35 & 214,33 & 8,10 & 31,19 & 107,35 & 209,94 & 162,52 & 98,61 & 800,85 & 501 & 2085 \\
\hline Lendvajakabfa & 39 & 181,20 & 8,97 & 101,10 & 193,85 & 218,66 & 145,55 & 205,34 & 953,58 & 128 & 794 \\
\hline Lesencefalu & 338 & 216,84 & 30,61 & 60,16 & 127,97 & 208,30 & 165,90 & 68,90 & 818,52 & 437 & 1947 \\
\hline Libickozma & 62 & 254,46 & 45,01 & 100,16 & 76,33 & 190,66 & 140,01 & 97,61 & 804,08 & 492 & 2062 \\
\hline Lickóvadamos & 224 & 182,31 & 22,15 & 41,85 & 151,13 & 236,40 & 190,82 & 49,34 & 832,14 & 399 & 1845 \\
\hline Liget & 430 & 205,81 & 36,03 & 41,33 & 153,29 & 191,24 & 189,66 & 17,97 & 794,00 & 530 & 2145 \\
\hline Ligetfalva & 54 & 225,42 & 79,24 & 106,88 & 206,60 & 219,19 & 181,35 & 76,08 & 987,88 & 95 & 594 \\
\hline Liptód & 232 & 190,06 & 78,48 & 93,95 & 105,41 & 127,74 & 168,58 & 12,21 & 682,47 & 877 & 2711 \\
\hline Lispeszentadorján & 333 & 192,11 & 41,84 & 50,96 & 170,76 & 192,70 & 158,25 & 3,20 & 758,86 & 648 & 2379 \\
\hline Liszó & 409 & 205,03 & 60,48 & 82,08 & 121,03 & 278,29 & 165,18 & 21,25 & 851,25 & 336 & 1669 \\
\hline Litka & 51 & 166,34 & 13,17 & 51,08 & 114,32 & 215,82 & 139,49 & 59,61 & 708,75 & 809 & 2619 \\
\hline Lócs & 130 & 207,30 & 54,52 & 74,67 & 238,58 & 248,04 & 198,69 & 69,11 & 1016,23 & 72 & 438 \\
\hline Lókút & 473 & 203,95 & 56,17 & 101,09 & 146,62 & 210,97 & 187,85 & 24,33 & 829,89 & 404 & 1866 \\
\hline Lórév & 311 & 225,46 & 163,51 & 175,95 & 202,08 & 262,07 & 166,88 & 17,88 & 1037,88 & 59 & 350 \\
\hline Lothárd & 268 & 218,72 & 48,73 & 81,48 & 171,67 & 221,19 & 192,36 & 26,32 & 878,99 & 272 & 1418 \\
\hline Lovas & 452 & 271,16 & 113,20 & 138,72 & 178,02 & 252,13 & 214,48 & 149,27 & 1178,26 & 12 & 81 \\
\hline Lovászhetény & 290 & 199,56 & 37,78 & 51,52 & 70,94 & 182,29 & 208,27 & 16,90 & 715,75 & 787 & 2591 \\
\hline Lulla & 192 & 182,53 & 54,80 & 74,90 & 162,61 & 210,82 & 169,17 & 10,25 & 790,18 & 545 & 2180 \\
\hline Lúzsok & 264 & 284,24 & 6,74 & 7,78 & 101,18 & 65,84 & 149,44 & 0,00 & 607,44 & 1013 & 2873 \\
\hline Maglóca & 101 & \begin{tabular}{|l|}
196,77 \\
\end{tabular} & 36,45 & 55,57 & 128,63 & 228,04 & 199,98 & 34,27 & 824,13 & 419 & 1901 \\
\hline Magosliget & 287 & 254,81 & 39,73 & 32,59 & 85,01 & 169,87 & 87,37 & 28,54 & 665,32 & 910 & 2759 \\
\hline Magyardombegyház & 269 & $\begin{array}{ll}169,75 \\
\end{array}$ & 30,54 & $\begin{array}{ll}49,68 \\
\end{array}$ & \begin{tabular}{ll|}
173,78 \\
\end{tabular} & 166,13 & 141,43 & 18,22 & 699,86 & 834 & 2653 \\
\hline Magyarföld & 51 & 252,16 & 94,13 & 126,21 & 97,40 & 220,89 & 140,01 & 11,82 & 816,39 & 445 & 1967 \\
\hline Magyarkeresztúr & 464 & 189,25 & 35,95 & 47,85 & 138,80 & 251,42 & 172,51 & 17,34 & 805,27 & 485 & 2048 \\
\hline Magyarlukafa & 104 & 206,37 & 91,10 & 74,76 & 64,47 & 169,70 & 144,52 & 150,28 & 826,44 & 411 & 1885 \\
\hline Magyarmecske & 339 & 225,24 & 55,43 & 49,30 & 201,87 & 156,93 & 167,97 & 21,69 & 829,12 & 408 & 1873 \\
\hline Magyarnádalja & 225 & 251,24 & 70,28 & 92,85 & 130,21 & 260,53 & 195,19 & 11,42 & 918,88 & 183 & 1066 \\
\hline Magyarsarlós & 324 & 200,18 & 51,99 & 70,66 & 95,28 & 229,61 & 199,31 & 25,00 & 801,38 & 498 & 2081 \\
\hline Magyarszecsöd & 464 & 198,95 & 64,21 & 81,15 & 121,59 & 234,73 & 208,69 & 10,56 & 838,74 & 377 & 1780 \\
\hline Magyarszentmiklós & 278 & 201,63 & 51,61 & 103,29 & 122,85 & 250,57 & 201,09 & 5,16 & 832,91 & 395 & 1839 \\
\hline Magyarszombatfa & 271 & 200,40 & 74,98 & 78,60 & 202,18 & 247,53 & 162,97 & 162,66 & 1050,72 & 47 & 299 \\
\hline Magyartelek & 237 & 224,68 & 21,11 & 28,26 & 47,22 & 159,26 & 165,26 & 30,34 & 647,87 & 953 & 2806 \\
\hline Mánd & 275 & 224,29 & 27,42 & 35,92 & 127,52 & 204,25 & 150,42 & 28,91 & 762,81 & 632 & 2352 \\
\hline Maráza & 198 & 184,99 & 42,77 & 81,16 & 134,04 & 221,68 & 160,25 & 64,78 & 808,51 & 473 & 2028 \\
\hline
\end{tabular}




\begin{tabular}{|c|c|c|c|c|c|c|c|c|c|c|c|}
\hline Településnév & $\begin{array}{l}\text { Népesség- } \\
\text { szám, } 2010\end{array}$ & $\begin{array}{l}\text { Népes- } \\
\text { ség }\end{array}$ & $\begin{array}{l}\text { Társa- } \\
\text { dalom }\end{array}$ & $\begin{array}{l}\text { Társa- } \\
\text { dalom } \\
(2011)\end{array}$ & Ellátottság & Gazdaság & $\begin{array}{l}\text { Közle- } \\
\text { kedés }\end{array}$ & $\begin{array}{l}\text { Idegen- } \\
\text { forgalom }\end{array}$ & $\begin{array}{l}\text { Összfej- } \\
\text { lettség }\end{array}$ & $\begin{array}{c}\begin{array}{c}\text { H. Apró- } \\
\text { falu }\end{array} \\
\end{array}$ & $\begin{array}{c}\text { H. Fal- } \\
\text { vak }\end{array}$ \\
\hline Marcalgergelyi & 423 & 190,93 & 29,58 & 39,91 & 212,42 & 212,08 & 138,67 & 30,29 & 813,97 & 457 & 1987 \\
\hline Márfa & 229 & 217,36 & 55,41 & 60,18 & 144,85 & 206,45 & 192,27 & 49,60 & 865,94 & 305 & 1533 \\
\hline Márkháza & 256 & 213,76 & 34,01 & 40,09 & 165,08 & 151,10 & 184,99 & 10,54 & 759,49 & 646 & 2376 \\
\hline Markóc & 69 & 204,34 & 40,15 & 37,11 & 85,31 & 183,64 & 152,03 & 29,59 & 695,06 & 851 & 2674 \\
\hline Markotabödöge & 495 & 206,47 & 41,10 & 54,06 & 165,43 & 241,58 & 184,78 & 9,90 & 849,25 & 342 & 1684 \\
\hline Maróc & 91 & 137,37 & 17,72 & 30,15 & 104,66 & 179,06 & 147,29 & 9,31 & 595,41 & 1026 & 2886 \\
\hline Marócsa & 111 & 202,17 & 30,81 & 25,74 & 58,74 & 114,91 & 160,46 & 42,52 & 609,60 & 1009 & 2869 \\
\hline Márok & 479 & 191,33 & 54,09 & 77,86 & 174,22 & 216,39 & 165,06 & 19,13 & 820,22 & 431 & 1932 \\
\hline Márokföld & 54 & 174,87 & 25,86 & 89,92 & 132,25 & 216,86 & 153,39 & 120,80 & 824,03 & 420 & 1902 \\
\hline Márokpapi & 445 & 206,77 & 33,72 & 60,66 & 168,75 & 158,94 & 138,91 & 35,51 & 742,59 & 705 & 2471 \\
\hline Martonfa & 229 & 232,18 & 62,30 & 78,91 & 103,96 & 238,22 & 205,50 & 10,70 & 852,86 & 331 & 1655 \\
\hline Martonyi & 495 & 186,88 & 32,35 & 39,20 & 93,63 & 139,80 & 137,86 & 26,15 & 616,66 & 1000 & 2859 \\
\hline Matty & 367 & 213,47 & 35,33 & 39,49 & 168,78 & 165,26 & 186,87 & 40,60 & 810,31 & 468 & 2017 \\
\hline Mátyus & 301 & 184,57 & 15,03 & 20,89 & 141,56 & 181,07 & 106,79 & 36,29 & 665,30 & 911 & 2760 \\
\hline Mecsekpölöske & 442 & 208,96 & 44,15 & 56,07 & 130,96 & 197,28 & 204,38 & 33,38 & 819,11 & 435 & 1941 \\
\hline$\overline{\text { Megyehid }}$ & 329 & 256,63 & 45,37 & 55,59 & 125,71 & 243,64 & 191,58 & 11,67 & 874,60 & 282 & 1467 \\
\hline Megyer & 44 & 163,37 & 44,66 & 68,94 & 46,61 & 175,08 & 179,76 & 110,00 & 719,47 & 775 & 2575 \\
\hline Mekényes & 308 & 191,74 & 46,70 & 58,57 & 99,87 & 167,40 & 120,40 & 17,96 & 644,07 & 960 & 2813 \\
\hline Mencshely & 269 & 235,61 & 49,98 & 62,52 & 179,36 & 196,77 & 163,15 & 71,03 & 895,90 & 227 & 1261 \\
\hline Merenye & 307 & 179,15 & 24,06 & 34,79 & 77,27 & 136,79 & 164,37 & 23,95 & 605,59 & 1017 & 2877 \\
\hline Mérges & 89 & 225,84 & 35,40 & 59,95 & 208,97 & 271,71 & 183,33 & 31,70 & 956,95 & 123 & 772 \\
\hline Mesterháza & 154 & 179,39 & 42,51 & 67,13 & 208,78 & 273,75 & 191,39 & 26,86 & 922,69 & 175 & 1034 \\
\hline Mesteri & 273 & 176,20 & 63,09 & 55,77 & 131,81 & 243,67 & 186,43 & 164,62 & 965,82 & 114 & 716 \\
\hline Meszes & 200 & 169,21 & 35,50 & 48,23 & 203,85 & 148,53 & 138,10 & 26,53 & 721,72 & 771 & 2569 \\
\hline Meszlen & 229 & 208,55 & 67,69 & 65,81 & 151,19 & 271,67 & 198,41 & 18,79 & 916,30 & 192 & 1097 \\
\hline Mezöd & 138 & 173,69 & 39,83 & 48,48 & 112,45 & 205,80 & 188,10 & 26,15 & 746,01 & 697 & 2454 \\
\hline Mezöhék & 368 & 189,21 & 39,92 & 47,33 & 201,41 & 213,42 & 161,90 & 23,71 & 829,58 & 405 & 1870 \\
\hline Mihályfa & 398 & 207,75 & 57,94 & 64,94 & 160,59 & 246,46 & 174,62 & 15,00 & 862,35 & 312 & 1562 \\
\hline Mikekarácsonyfa & 308 & 230,72 & 29,50 & 31,81 & 104,55 & 176,56 & 169,97 & 6,01 & 717,30 & 782 & 2583 \\
\hline Miklósi & 242 & 204,96 & 82,49 & 77,11 & 144,88 & 196,17 & 163,25 & 17,78 & 809,53 & 469 & 2022 \\
\hline Mikosszéplak & 373 & 213,21 & 33,66 & 31,23 & 157,24 & 196,49 & 168,13 & 23,37 & 792,11 & 537 & 2160 \\
\hline Milejszeg & 345 & 200,69 & 31,24 & 50,71 & 123,40 & 233,74 & 191,17 & 25,55 & 805,78 & 484 & 2047 \\
\hline Mindszentkálla & 293 & 194,40 & 48,91 & 51,18 & 112,54 & 205,22 & 176,05 & 109,15 & 846,28 & 353 & 1715 \\
\hline Misefa & 300 & 226,33 & 102,84 & 98,50 & 167,66 & 247,66 & 201,17 & 29,75 & 975,41 & 107 & 662 \\
\hline Miszla & 321 & 175,36 & 34,05 & 43,11 & 185,37 & 193,49 & 118,15 & 16,29 & 722,70 & 768 & 2565 \\
\hline Mogyoróska & 79 & 213,23 & 71,96 & 122,84 & 105,04 & 274,89 & 140,82 & 172,05 & 977,99 & 104 & 649 \\
\hline$\overline{M o h a}$ & 570 & 315,48 & 91,73 & 100,16 & 161,52 & 236,03 & 214,07 & 19,97 & 1038,79 & 58 & 347 \\
\hline Molnaszecsőd & 445 & 251,63 & 53,02 & 72,75 & 153,39 & 245,72 & 200,39 & 35,49 & 939,63 & 147 & 890 \\
\hline Molvány & 207 & 187,67 & 24,71 & 39,43 & 123,96 & 202,87 & 186,74 & 11,84 & 737,79 & 720 & 2499 \\
\hline Monaj & 256 & 191,75 & 15,05 & 25,26 & 134,31 & 126,24 & 167,16 & 9,57 & 644,09 & 959 & 2812 \\
\hline Mónosbél & 414 & 225,17 & 61,49 & 60,68 & 158,25 & 199,09 & 224,12 & 34,17 & 902,29 & 213 & 1209 \\
\hline Monoszló & 139 & 180,26 & 44,54 & 68,27 & 110,82 & 237,45 & 155,03 & 117,67 & 845,78 & 355 & 1720 \\
\hline Monyoród & 190 & 206,08 & 61,65 & 60,83 & 120,67 & 168,32 & 178,65 & 10,00 & 745,36 & 698 & 2456 \\
\hline Möcsény & 354 & 210,16 & 51,36 & 56,47 & 179,87 & 202,62 & 207,35 & 16,92 & 868,28 & 297 & 1516 \\
\hline Mucsfa & 416 & 209,34 & 25,74 & 29,87 & 125,99 & 245,40 & 175,55 & 33,57 & 815,58 & 450 & 1974 \\
\hline Mucsi & 490 & 199,94 & 28,92 & 33,45 & 126,72 & 124,93 & 136,34 & 23,72 & 640,56 & 970 & 2823 \\
\hline Murarátka & 266 & 194,67 & 27,73 & 38,06 & 91,75 & 181,58 & 175,94 & 43,92 & 715,59 & 789 & 2594 \\
\hline Murga & 75 & 154,37 & 20,18 & 48,69 & 240,25 & 180,92 & 155,27 & 45,03 & 796,01 & 523 & 2131 \\
\hline Nadap & 540 & 310,29 & 65,25 & 116,00 & 249,62 & 250,73 & 198,53 & 53,62 & 1128,03 & 20 & 135 \\
\hline Nagybakónak & 442 & 177,13 & 26,69 & 39,51 & 89,56 & 200,03 & 153,53 & 22,82 & 669,75 & 898 & 2745 \\
\hline Nagybudmér & 216 & 180,38 & 32,32 & 52,14 & 145,47 & 206,35 & 157,48 & 36,42 & 758,43 & 652 & 2384 \\
\hline Nagycsány & 173 & 216,20 & 32,82 & 42,62 & 113,00 & 153,41 & 175,34 & 20,24 & 711,01 & 803 & 2611 \\
\hline Nagycsepely & 397 & 202,17 & 41,32 & 47,94 & 118,14 & 191,19 & 150,45 & 33,99 & 737,26 & 726 & 2505 \\
\hline Nagydém & 393 & 200,81 & 28,63 & 32,68 & 123,02 & 153,71 & 133,56 & 11,42 & 651,16 & 948 & 2801 \\
\hline Nagygeresd & 296 & 188,14 & 36,31 & 46,02 & 154,93 & 242,33 & 164,77 & 81,54 & 868,02 & 298 & 1519 \\
\hline Nagygörbö & 195 & 173,24 & 41,43 & 40,55 & 125,37 & 195,16 & 170,68 & 50,84 & 756,72 & 663 & 2400 \\
\hline Nagyhajmás & 391 & 189,23 & 52,91 & 56,92 & 102,52 & 164,32 & 131,73 & 21,09 & 661,79 & 917 & 2767 \\
\hline Nagyhódos & 130 & 174,33 & 37,54 & 49,98 & 157,44 & 267,55 & 78,06 & 116,83 & 831,74 & 400 & 1852 \\
\hline $\mid \overline{\text { Nagyhuta }}$ & 95 & 233,31 & 28,36 & 88,56 & 270,75 & 260,34 & 100,01 & 106,37 & 9999,14 & 89 & 531 \\
\hline Nagykeresztúr & 272 & 208,74 & 53,66 & 62,31 & 158,56 & 190,15 & 191,48 & 4,26 & 806,86 & 479 & 2038 \\
\hline Nagykinizs & 380 & 230,51 & 30,63 & 34,08 & 171,84 & 165,73 & 171,66 & 16,45 & 786,82 & 560 & 2210 \\
\hline Nagykölked & 170 & 258,34 & 34,12 & 61,16 & 131,48 & 195,84 & 177,66 & 27,49 & 824,94 & 417 & 1897 \\
\hline Nagykutas & 485 & 232,47 & 48,39 & 67,35 & 198,63 & 239,92 & 194,55 & 18,22 & 932,17 & 156 & 950 \\
\hline \begin{tabular}{|l} 
Nagylengyel \\
\end{tabular} & 553 & 259,41 & 84,79 & 86,50 & 225,53 & 264,78 & 209,74 & 31,00 & 1075,24 & 32 & 220 \\
\hline Nagymizdó & 128 & 185,65 & 69,67 & 91,28 & 128,02 & 265,29 & 188,45 & 5,54 & 842,62 & 365 & 1749 \\
\hline Nagypáli & 460 & 353,56 & 74,54 & 114,50 & 173,37 & 248,67 & 210,68 & 53,64 & 1114,46 & 23 & 155 \\
\hline Nagypall & 443 & 220,19 & 65,58 & 74,00 & 144,29 & 220,84 & 207,02 & 25,08 & 883,01 & 264 & 1374 \\
\hline Nagypirit & 292 & 175,86 & 52,90 & 52,81 & 166,88 & 231,48 & 118,74 & 23,29 & 769,14 & 615 & 2312 \\
\hline Nagyrákos & 306 & 201,80 & 52,05 & 75,93 & 169,03 & 248,52 & 195,31 & 80,36 & 947,07 & 137 & 831 \\
\hline Nagyszékely & 448 & 205,29 & 41,76 & 58,62 & 146,83 & 170,59 & 120,60 & 17,74 & 702,82 & 826 & 2643 \\
\hline Nagytilaj & 147 & 155,33 & 34,23 & 50,86 & 101,53 & 190,31 & 153,04 & 6,93 & 641,37 & 967 & 2820 \\
\hline
\end{tabular}




\begin{tabular}{|c|c|c|c|c|c|c|c|c|c|c|c|}
\hline Településnév & $\begin{array}{l}\text { Népesség- } \\
\text { szám, } 2010\end{array}$ & $\begin{array}{l}\text { Népes- } \\
\text { ség }\end{array}$ & $\begin{array}{l}\text { Társa- } \\
\text { dalom }\end{array}$ & $\begin{array}{l}\text { Társa- } \\
\text { dalom } \\
(2011)\end{array}$ & Ellátottság & Gazdaság & $\begin{array}{l}\text { Közle- } \\
\text { kedés }\end{array}$ & $\begin{array}{c}\text { Idegen- } \\
\text { forgalom }\end{array}$ & $\begin{array}{l}\text { Összfej- } \\
\text { lettség }\end{array}$ & $\begin{array}{c}\begin{array}{c}\text { H. Apró- } \\
\text { falu }\end{array} \\
\end{array}$ & $\begin{array}{c}\text { H. Fal- } \\
\text { vak }\end{array}$ \\
\hline Nagytótfalu & 409 & 239,78 & 31,48 & 32,92 & 78,04 & 151,02 & 184,91 & 31,14 & 716,36 & 785 & 2587 \\
\hline Nagytőke & 454 & 184,85 & 35,40 & 41,77 & 134,89 & 250,93 & 153,68 & 5,40 & 765,15 & 626 & 2334 \\
\hline Nagyváty & 369 & 218,93 & 16,77 & 27,31 & 76,31 & 178,02 & 184,40 & 29,88 & 704,31 & 819 & 2635 \\
\hline Nagyvejke & 169 & 172,75 & 26,69 & 47,93 & 140,40 & 229,49 & 179,81 & 9,23 & 758,37 & 653 & 2386 \\
\hline Négyes & 298 & 182,84 & 54,68 & 65,96 & 243,20 & 205,76 & 152,53 & 40,00 & 879,02 & 271 & 1417 \\
\hline Nemesborzova & 94 & 193,29 & 57,56 & 55,59 & 83,93 & 194,75 & 145,37 & 10,00 & 684,90 & 869 & 2702 \\
\hline Nemescsó & 314 & 226,19 & 71,15 & 82,37 & 185,61 & 260,44 & 205,40 & 12,97 & 961,76 & 118 & 739 \\
\hline Nemeshany & 430 & 220,51 & 36,32 & 49,72 & 160,94 & 209,39 & 176,61 & 25,01 & 828,78 & 409 & 1875 \\
\hline Nemeshetés & 283 & 182,00 & 32,43 & 35,82 & 181,10 & 196,62 & 190,45 & 29,27 & 811,87 & 463 & 2005 \\
\hline Nemeske & 271 & 201,32 & 48,58 & 33,40 & 99,70 & 175,99 & 175,36 & 9,04 & 710,00 & 806 & 2615 \\
\hline Nemeskér & 215 & 195,05 & 45,72 & 54,76 & $\overline{150,21}$ & 259,47 & 133,71 & 32,80 & 816,96 & 443 & 1963 \\
\hline Nemeskeresztúr & 302 & 184,31 & 31,85 & 36,17 & 141,90 & 219,26 & 153,51 & 27,72 & 758,56 & 649 & 2381 \\
\hline Nemeskisfalud & 111 & 268,21 & 39,69 & 19,34 & 106,89 & 196,84 & 152,93 & 32,08 & 796,64 & $\overline{518}$ & 2121 \\
\hline Nemeskocs & 335 & 221,92 & 43,22 & 52,19 & 121,45 & 266,15 & 178,55 & 18,11 & 849,40 & 341 & 1682 \\
\hline Nemeskolta & 381 & 231,16 & 47,27 & 55,37 & 181,06 & 256,73 & 176,96 & 15,90 & 909,08 & 201 & 1154 \\
\hline Nemesládony & 136 & 208,68 & 54,51 & 62,00 & 188,39 & 239,38 & 172,00 & 33,07 & 896,02 & 226 & 1260 \\
\hline Nemesmedves & 20 & 219,17 & 80,34 & 96,23 & 144,52 & 224,14 & 182,89 & 0,00 & 851,05 & 337 & 1670 \\
\hline Nemesnép & 129 & 180,74 & 21,82 & 33,29 & 111,06 & 234,93 & 162,36 & 49,97 & 760,88 & 642 & 2366 \\
\hline Nemespátró & 320 & 191,15 & 46,59 & 50,61 & 111,94 & 279,47 & 140,71 & 12,00 & 781,86 & 579 & 2247 \\
\hline Nemesrádó & 319 & 200,95 & 29,34 & 46,43 & 169,04 & 164,39 & 193,94 & 15,01 & 772,68 & 605 & 2293 \\
\hline Nemesrempehollós & 287 & 203,75 & 35,46 & 43,01 & 181,81 & 219,81 & 180,52 & 27,05 & 848,41 & 344 & 1690 \\
\hline Nemessándorháza & 322 & 188,08 & 52,76 & 70,38 & 167,04 & 222,80 & 187,12 & 16,24 & 834,04 & 391 & 1830 \\
\hline Nemesszentandrás & 292 & 237,15 & 42,26 & 58,15 & 154,16 & 208,45 & 188,38 & 15,05 & 845,45 & 358 & 1724 \\
\hline Nemesvita & 391 & 213,01 & 71,83 & 81,77 & 167,80 & 224,45 & 168,05 & 81,43 & 926,56 & 167 & 1001 \\
\hline Németbánya & 100 & 229,83 & 159,81 & 256,88 & 88,26 & 220,80 & 173,08 & 134,51 & 1006,29 & 80 & 491 \\
\hline Németfalu & 191 & 192,18 & 54,02 & 66,96 & 191,55 & 247,06 & 177,23 & 30,12 & 892,15 & 237 & 1285 \\
\hline Nóráp & 220 & 190,09 & 36,69 & 58,56 & 187,57 & 238,45 & 179,51 & 31,66 & 863,97 & 307 & 1550 \\
\hline Nyalka & 477 & 234,31 & \begin{tabular}{|l|}
56,37 \\
\end{tabular} & 74,07 & 194,89 & 247,99 & 191,61 & 31,35 & 956,51 & 124 & 775 \\
\hline Nyésta & 58 & 192,27 & 2,75 & 16,54 & 105,06 & 112,69 & 152,20 & 0,00 & 564,97 & 1050 & 2912 \\
\hline Nyim & 312 & 221,30 & 56,02 & 69,67 & 127,76 & 198,58 & 135,47 & 17,86 & 756,99 & 661 & 2397 \\
\hline Nyíri & 447 & 208,21 & 41,08 & 42,91 & 131,13 & 181,35 & 117,57 & 20,97 & 700,30 & 832 & 2650 \\
\hline Nyomár & 350 & 229,07 & 21,87 & 40,67 & 150,99 & 182,58 & 180,97 & 7,81 & 773,29 & 600 & 2288 \\
\hline Nyögér & 328 & 196,83 & 85,58 & 91,17 & 188,31 & 245,26 & 188,71 & 38,95 & 943,64 & 141 & 857 \\
\hline Nyugotszenterzsébet & 259 & 242,23 & 18,30 & 32,12 & 117,43 & 83,04 & 178,99 & 25,90 & 665,88 & 908 & 2756 \\
\hline Óbánya & 156 & 189,83 & 106,64 & 134,58 & 187,18 & 258,81 & 185,08 & 249,13 & 1176,66 & 13 & 82 \\
\hline Óbudavár & 60 & 235,72 & 237,34 & 264,84 & 111,03 & 254,30 & 169,65 & 158,13 & 1166,16 & 14 & 89 \\
\hline Ócsárd & 453 & 214,34 & 37,35 & 45,37 & 161,82 & 176,97 & 179,93 & 43,86 & 814,26 & 456 & 1985 \\
\hline Ófalu & 340 & 191,20 & 129,53 & 150,33 & 145,16 & 236,03 & 179,01 & 37,23 & 918,16 & 186 & 1076 \\
\hline Óföldeák & 496 & 166,89 & 39,93 & 47,63 & 125,81 & 209,30 & 157,07 & 14,82 & 713,82 & 796 & 2601 \\
\hline Okorág & 183 & 208,56 & 21,20 & 26,92 & 117,17 & 152,52 & 179,39 & 43,74 & 722,56 & 769 & 2566 \\
\hline Okorvölgy & 90 & 191,62 & 38,99 & 44,67 & 71,65 & 147,27 & 167,23 & 69,13 & 685,88 & 868 & 2701 \\
\hline Olaszfa & 434 & 188,06 & 58,83 & 67,83 & 206,48 & 231,68 & 181,80 & 17,38 & 884,22 & 261 & 1361 \\
\hline Olcsvaapáti & 323 & 192,76 & 29,78 & 39,51 & 115,63 & 193,36 & 123,61 & 50,35 & 705,49 & 815 & 2630 \\
\hline Old & 361 & 229,17 & 24,19 & 28,97 & 54,71 & 169,96 & 155,43 & 16,79 & 650,24 & 951 & 2804 \\
\hline Ólmod & 108 & 256,66 & 92,20 & 149,41 & 186,56 & 247,96 & 191,74 & 95,84 & 1070,96 & 34 & 239 \\
\hline Oltárc & 294 & 200,14 & 13,23 & 21,42 & 97,98 & 149,72 & 138,93 & 31,43 & 631,44 & 983 & 2837 \\
\hline Orbányosfa & 136 & 217,05 & 11,28 & 16,87 & 139,42 & 188,61 & 179,99 & 33,09 & 769,44 & 614 & 2311 \\
\hline Orci & 575 & 252,44 & 71,74 & 85,57 & 177,89 & 235,30 & 207,92 & 8,53 & 953,83 & 127 & 792 \\
\hline Ordas & 466 & 185,07 & 62,30 & 82,03 & 173,15 & 208,45 & 163,17 & 20,52 & 812,66 & 460 & 1997 \\
\hline Orfalu & 71 & 241,74 & 204,32 & 196,70 & 66,26 & 243,67 & 167,32 & 26,85 & 950,16 & 134 & 810 \\
\hline Ormándlak & 134 & 233,27 & 16,06 & 29,04 & 121,18 & 182,26 & 178,06 & 18,14 & 748,97 & 687 & 2436 \\
\hline Oroszi & 146 & 189,60 & 20,78 & 37,24 & 132,74 & 172,81 & 159,33 & 76,90 & 752,16 & 674 & 2417 \\
\hline Oroszló & 344 & 225,52 & 39,82 & 40,86 & 93,09 & 176,09 & 211,89 & 14,25 & 760,67 & 643 & 2367 \\
\hline Orosztony & 488 & 218,37 & 28,84 & 34,58 & 127,05 & 182,59 & 165,55 & 32,32 & 754,71 & 665 & 2405 \\
\hline Ortaháza & 122 & 169,38 & 18,96 & 23,06 & 194,09 & 216,93 & 167,85 & 5,12 & 772,33 & 606 & 2295 \\
\hline Oszlár & 418 & 213,92 & 41,06 & 41,39 & 156,70 & 213,44 & 193,39 & 17,59 & 836,10 & 387 & 1805 \\
\hline Ózdfalu & 195 & 236,87 & 9,55 & 18,53 & 45,94 & 111,98 & 159,00 & 12,57 & 575,90 & 1042 & 2904 \\
\hline Ozmánbük & 195 & 176,55 & 66,20 & 83,80 & 158,33 & 231,70 & 182,24 & 39,25 & 854,27 & 327 & 1645 \\
\hline Öcs & 222 & 195,77 & 33,15 & 43,00 & 110,31 & 211,47 & 175,86 & 77,19 & 803,75 & 494 & 2066 \\
\hline Ömböly & 465 & 206,97 & 16,53 & 19,86 & 90,98 & 154,48 & 121,98 & 15,27 & 606,21 & 1015 & 2875 \\
\hline Örimagyarósd & 230 & 182,37 & 55,04 & 74,00 & 100,61 & 250,59 & 182,73 & 114,41 & 885,75 & 256 & 1342 \\
\hline Örménykút & 426 & 162,61 & 108,68 & 95,12 & 166,65 & 279,51 & 182,32 & 11,51 & 911,27 & 200 & 1136 \\
\hline Örvényes & 172 & 220,29 & 95,41 & 104,16 & 281,76 & 261,52 & 210,49 & 242,62 & 1312,09 & 4 & 24 \\
\hline Ösagárd & 345 & 211,39 & 103,11 & 121,81 & 198,21 & 269,79 & 135,37 & 7,10 & 924,96 & 171 & 1011 \\
\hline Pácsony & 295 & 194,03 & 44,60 & 55,41 & 190,42 & 257,72 & 195,66 & 30,33 & 912,76 & 196 & 1124 \\
\hline Padár & 140 & 208,22 & 33,97 & 35,07 & 148,27 & 223,30 & 175,48 & 11,24 & 800,49 & 503 & 2091 \\
\hline Palé & 115 & 229,12 & 14,59 & 29,08 & 150,74 & 154,52 & 186,40 & 23,12 & 758,49 & 650 & 2382 \\
\hline Pálfiszeg & 168 & 167,01 & 37,85 & 46,63 & 167,33 & 244,45 & 187,97 & 17,07 & 821,68 & 428 & 1916 \\
\hline Páli & 407 & 196,46 & 58,97 & 65,68 & 261,11 & 253,15 & 163,03 & 32,16 & 964,88 & 116 & 719 \\
\hline Palkonya & 325 & 224,01 & 48,44 & 76,67 & 145,46 & 228,16 & 174,24 & 98,04 & 918,36 & 185 & 1073 \\
\hline Pálmajor & 372 & 286,71 & 16,41 & 19,62 & 51,33 & 136,36 & 154,75 & 0,00 & 645,56 & 955 & 2808 \\
\hline
\end{tabular}




\begin{tabular}{|c|c|c|c|c|c|c|c|c|c|c|c|}
\hline Településnév & $\begin{array}{l}\text { Népesség- } \\
\text { szám, } 2010\end{array}$ & $\begin{array}{l}\text { Népes- } \\
\text { ség }\end{array}$ & $\begin{array}{l}\text { Társa- } \\
\text { dalom }\end{array}$ & $\begin{array}{l}\text { Társa- } \\
\text { dalom } \\
\text { (2011) }\end{array}$ & Ellátottság & Gazdaság & $\begin{array}{l}\text { Közle- } \\
\text { kedés }\end{array}$ & $\begin{array}{l}\text { Idegen- } \\
\text { forgalom }\end{array}$ & $\begin{array}{l}\text { Összfej- } \\
\text { lettség }\end{array}$ & $\begin{array}{c}\text { H. Apró- } \\
\text { falu }\end{array}$ & $\begin{array}{c}\text { H. Fal- } \\
\text { vak }\end{array}$ \\
\hline Paloznak & 506 & 278,27 & 107,37 & 142,17 & 221,59 & 261,25 & 226,55 & 170,77 & 1265,79 & 8 & 40 \\
\hline Pamlény & 55 & 195,30 & 27,64 & 58,01 & 64,66 & 121,58 & 102,75 & 10,00 & 521,92 & 1066 & 2929 \\
\hline Pamuk & 281 & 216,90 & 29,42 & 27,69 & 124,14 & 132,36 & 158,64 & 8,72 & 670,19 & 897 & 2744 \\
\hline Pankasz & 462 & 200,31 & 61,04 & 62,34 & 209,52 & 191,46 & 187,52 & 35,55 & 885,40 & 257 & 1347 \\
\hline Pányok & 76 & 113,99 & 50,21 & 73,41 & 226,64 & 166,18 & 148,61 & 74,42 & 780,05 & 586 & 2259 \\
\hline Pápadereske & 290 & 240,92 & 42,86 & 64,37 & 222,09 & 234,38 & 177,91 & 8,45 & \begin{tabular}{l|l|}
926,62 \\
\end{tabular} & 166 & 1000 \\
\hline Pápasalamon & 361 & 191,32 & 20,76 & 31,97 & 152,92 & 155,21 & 162,88 & 55,44 & \begin{tabular}{l|l}
738,53 \\
\end{tabular} & 718 & 2495 \\
\hline Pápoc & 336 & 154,74 & 27,94 & 29,38 & 261,89 & 214,46 & 145,09 & 34,23 & 838,36 & 381 & 1787 \\
\hline Páprád & 178 & 185,06 & 26,43 & 27,39 & 140,71 & 161,78 & 168,27 & 8,42 & 690,67 & 860 & 2687 \\
\hline Pásztori & 380 & 195,39 & 35,47 & 40,86 & 123,93 & 237,41 & 182,12 & 12,90 & 787,22 & 557 & 2207 \\
\hline Pat & 228 & 192,08 & \begin{tabular}{l|l|}
35,42 \\
\end{tabular} & 53,99 & 145,94 & 220,14 & 149,45 & 13,86 & 756,88 & 662 & 2399 \\
\hline Patalom & 353 & 159,55 & \begin{tabular}{l|l|}
59,03 \\
\end{tabular} & 72,17 & 106,21 & 208,34 & 163,42 & 6,94 & \begin{tabular}{l|l}
703,50 \\
\end{tabular} & 823 & 2639 \\
\hline Patapoklosi & 410 & 217,27 & 28,29 & 29,00 & 74,99 & 139,50 & 177,25 & 5,98 & 643,29 & 963 & 2816 \\
\hline Patca & 56 & 168,75 & 101,89 & 111,68 & 52,92 & 178,32 & 183,25 & 43,77 & 728,90 & 752 & 2541 \\
\hline Patosfa & 265 & 187,61 & 26,57 & 45,71 & 100,92 & 151,49 & 139,10 & 18,50 & 624,19 & 992 & 2849 \\
\hline Pécsbagota & 106 & 215,50 & 22,40 & 23,74 & 137,06 & 180,47 & 189,79 & 23,12 & \begin{tabular}{|l|}
768,34 \\
\end{tabular} & 618 & 2316 \\
\hline Pécsdevecser & 118 & 177,65 & 68,84 & 82,76 & 186,10 & 210,14 & 174,87 & 1,65 & 819,25 & 434 & 1940 \\
\hline Pénzesgyör & 358 & 221,94 & 68,91 & 85,76 & 106,72 & 221,08 & 191,70 & 37,57 & 847,92 & 346 & 1699 \\
\hline Pere & 364 & 214,28 & 49,41 & 52,88 & 184,75 & 131,77 & 168,22 & 84,42 & 832,85 & 396 & 1840 \\
\hline Perecse & 38 & 235,15 & 62,97 & 146,57 & 143,51 & 233,64 & 125,87 & 0,00 & 801,13 & 500 & 2083 \\
\hline Pereked & 178 & 217,51 & 8,34 & 51,90 & 105,32 & 216,46 & 190,08 & 19,51 & 757,21 & 660 & 2395 \\
\hline Peröcsény & 349 & 173,10 & \begin{tabular}{l|l|}
59,02 \\
\end{tabular} & 93,10 & 204,09 & 255,89 & 111,87 & 115,58 & 919,55 & 181 & 1061 \\
\hline Peterd & 207 & 216,52 & 16,32 & 32,34 & 153,43 & 197,90 & 172,64 & 12,74 & 769,55 & 613 & 2310 \\
\hline Péterhida & 161 & 160,25 & 26,32 & 41,93 & 183,96 & 166,18 & 139,01 & 25,22 & $\begin{array}{ll}700,95 \\
\end{array}$ & 830 & 2647 \\
\hline \begin{tabular}{|l|} 
Pethöhenye \\
\end{tabular} & 444 & 242,82 & 44,30 & 65,63 & 135,94 & 230,65 & 200,48 & 14,76 & 868,95 & 296 & 1508 \\
\hline Petőmihályfa & 236 & 193,77 & \begin{tabular}{l|l|}
47,60 &
\end{tabular} & 61,72 & 81,33 & 226,58 & 184,05 & 16,47 & \begin{tabular}{l|l}
749,80 \\
\end{tabular} & 684 & 2433 \\
\hline Petrikeresztúr & 372 & 185,75 & \begin{tabular}{l|l|}
49,64 \\
\end{tabular} & 64,23 & 158,60 & 242,26 & 183,74 & 46,82 & 866,81 & 301 & 1527 \\
\hline Petrivente & 406 & 199,99 & 67,03 & 101,01 & 160,43 & 229,57 & 161,66 & 25,99 & 844,67 & 360 & 1732 \\
\hline Pettend & 149 & 222,83 & 39,34 & 32,09 & 116,22 & 143,15 & 156,59 & 26,45 & 704,58 & 818 & 2634 \\
\hline Pinkamindszent & 171 & 221,08 & 63,42 & 64,83 & 136,24 & 242,17 & 187,17 & 28,68 & 878,76 & 273 & 1420 \\
\hline Pinnye & 354 & 209,44 & \begin{tabular}{l|}
60,76 \\
\end{tabular} & 70,72 & 199,78 & 257,62 & 178,36 & 16,92 & 922,88 & 174 & 1031 \\
\hline Piskó & 265 & 221,11 & \begin{tabular}{l|}
26,62 \\
\end{tabular} & 27,24 & 123,18 & 32,05 & 146,26 & 19,25 & 568,46 & 1046 & 2908 \\
\hline Pócsa & 192 & 221,98 & 34,68 & 59,63 & 102,06 & 231,15 & 164,91 & 31,33 & 786,11 & 567 & 2219 \\
\hline Polány & 270 & 221,78 & \begin{tabular}{l|}
38,12 \\
\end{tabular} & 56,36 & 110,83 & 194,28 & 155,27 & 9,08 & 729,36 & 750 & 2539 \\
\hline Pornóapáti & 393 & 230,85 & 140,54 & 162,75 & 221,39 & 239,07 & 193,91 & 7,54 & 1033,29 & 60 & 362 \\
\hline Porpác & 153 & 226,95 & \begin{tabular}{l|}
30,43 \\
\end{tabular} & 37,52 & 101,53 & 213,96 & 180,19 & 4,99 & 758,05 & 655 & 2388 \\
\hline Porrog & 252 & 219,54 & \begin{tabular}{|l|}
21,43 \\
\end{tabular} & 28,21 & 133,55 & 210,86 & 148,79 & 29,29 & 763,45 & 631 & 2346 \\
\hline Porrogszentkirály & 323 & 194,49 & 60,83 & 61,87 & 114,82 & 240,16 & 159,38 & 29,83 & 799,52 & 507 & 2098 \\
\hline Porrogszentpál & 96 & 210,60 & \begin{tabular}{l|}
31,00 \\
\end{tabular} & 40,67 & 103,84 & 255,21 & 146,00 & 0,00 & 746,66 & 696 & 2451 \\
\hline Pórszombat & 321 & 179,20 & 46,45 & 58,95 & 175,86 & 244,24 & 180,89 & 27,03 & \begin{tabular}{l|l|}
853,67 \\
\end{tabular} & 329 & 1651 \\
\hline Porva & 485 & 207,28 & \begin{tabular}{l|}
57,70 \\
\end{tabular} & 105,35 & 181,85 & 230,57 & 187,51 & 124,24 & 989,16 & 94 & 589 \\
\hline Pósfa & 272 & 206,74 & \begin{tabular}{l|}
33,56 \\
\end{tabular} & 42,21 & 150,90 & 233,13 & 177,18 & 22,20 & 823,71 & 422 & 1904 \\
\hline Potony & 234 & 158,79 & 78,51 & 103,36 & 130,89 & 169,64 & 140,97 & 50,34 & 729,14 & 751 & 2540 \\
\hline Potyond & 106 & 205,67 & \begin{tabular}{l|l}
67,00 \\
\end{tabular} & 78,49 & 182,32 & 275,07 & 176,68 & 10,00 & 916,73 & 191 & 1092 \\
\hline Pölöskefö & 399 & 178,28 & 33,86 & 41,54 & 103,80 & 226,27 & 171,17 & 10,78 & 724,18 & 765 & 2562 \\
\hline Pördefölde & 65 & 204,86 & 10,85 & 25,71 & 59,54 & 189,67 & 143,66 & 10,00 & 618,59 & 998 & 2857 \\
\hline Pötréte & 292 & 177,04 & 35,65 & 47,17 & 124,81 & 227,83 & 196,31 & 30,46 & 792,11 & 538 & 2161 \\
\hline Pula & 211 & 198,70 & 97,28 & 123,83 & 184,11 & 254,61 & 174,03 & 67,55 & 976,28 & 105 & 658 \\
\hline Pusztaapáti & 36 & 146,94 & 25,41 & 22,68 & 56,65 & 152,15 & 157,97 & 121,57 & 660,71 & 923 & 2774 \\
\hline Pusztaberki & 130 & 264,99 & 63,62 & 98,63 & 279,93 & 226,39 & 161,61 & 0,00 & 996,53 & 90 & 543 \\
\hline Pusztacsalád & 281 & 206,72 & 38,83 & 50,68 & 236,61 & 238,77 & 120,62 & 17,44 & 858,99 & 318 & 1601 \\
\hline Pusztacsó & 158 & 235,58 & 26,03 & 34,32 & 157,20 & 244,85 & 170,67 & 2,34 & 836,68 & 384 & 1799 \\
\hline Pusztaederics & 177 & 184,61 & 25,80 & 45,24 & 243,82 & 188,94 & 161,33 & 36,93 & 841,44 & 369 & 1760 \\
\hline Pusztamiske & 439 & 214,20 & 15,03 & 21,38 & 92,84 & 158,97 & 161,25 & 19,43 & 661,74 & 918 & 2768 \\
\hline Pusztaottlaka & 395 & 169,89 & 75,67 & 81,36 & 170,72 & 232,39 & 161,15 & 6,21 & 816,03 & 449 & 1972 \\
\hline \begin{tabular}{|l|} 
Pusztaradvány \\
\end{tabular} & 251 & 321,50 & 30,98 & 27,92 & 18,80 & 73,97 & 135,71 & 63,49 & 644,44 & 958 & 2811 \\
\hline Pusztaszemes & 399 & 198,73 & 46,94 & 69,39 & 129,54 & 214,68 & 167,75 & 28,43 & 786,08 & 568 & 2220 \\
\hline Rábasebes & 94 & 160,29 & 46,45 & 58,81 & 279,81 & 255,24 & 152,95 & 46,07 & 940,83 & 144 & 881 \\
\hline Rábaszentmiklós & 144 & 197,63 & 74,93 & 73,43 & 196,70 & 259,60 & 189,07 & 27,02 & $\begin{array}{ll}944,96 \\
\end{array}$ & 139 & 848 \\
\hline Rábatöttös & 233 & 191,95 & 49,58 & 65,16 & 185,64 & 248,65 & 159,27 & 17,08 & 852,16 & 332 & 1662 \\
\hline Rábcakapi & 180 & 226,86 & 66,01 & 67,68 & 120,86 & 274,05 & 190,99 & 13,62 & 892,38 & 234 & 1282 \\
\hline Rádfalva & 246 & 208,14 & 31,76 & 26,04 & 117,32 & 155,95 & 161,66 & 19,93 & 694,77 & 852 & 2675 \\
\hline Rádóckölked & 286 & 229,37 & 45,08 & 66,50 & 184,58 & 239,81 & 200,32 & 57,13 & 956,29 & 125 & 777 \\
\hline Rakacaszend & 413 & 219,34 & \begin{tabular}{l|}
7,72 \\
\end{tabular} & 11,20 & 87,87 & 69,38 & 111,85 & 21,87 & \begin{tabular}{l|}
518,02 \\
\end{tabular} & 1069 & 2932 \\
\hline Ráksi & 479 & 195,09 & \begin{tabular}{l|l|}
47,13 \\
\end{tabular} & 60,82 & 200,69 & 207,97 & 177,31 & 10,42 & 838,61 & 379 & 1782 \\
\hline Ramocsa & 38 & 225,32 & 12,74 & 15,86 & 66,47 & 222,25 & 152,89 & 18,27 & 697,94 & 841 & 2663 \\
\hline Rápolt & 158 & 206,04 & 24,08 & 41,66 & 115,70 & 155,93 & 135,82 & 25,51 & 66 & 916 & 2766 \\
\hline Raposka & 260 & 250,57 & 71,32 & 85,46 & 217,64 & 250,01 & 188,57 & 53,71 & 1031,83 & 61 & 368 \\
\hline Rátót & 299 & 224,55 & 88,40 & 77,78 & 185,47 & 233,45 & 184,52 & 29,18 & \begin{tabular}{|c|}
945,57 \\
\end{tabular} & 138 & 843 \\
\hline Regéc & 103 & 190,82 & \begin{tabular}{l|l|}
59,31 \\
\end{tabular} & 73,90 & 90,92 & 237,23 & 135,13 & 120,00 & 833,41 & 393 & 1833 \\
\hline Regenye & 158 & 177,27 & 37,44 & 45,64 & 108,86 & 119,24 & 172,01 & 50,69 & 665,51 & 909 & 2757 \\
\hline
\end{tabular}




\begin{tabular}{|c|c|c|c|c|c|c|c|c|c|c|c|}
\hline Településnév & $\begin{array}{l}\text { Népesség- } \\
\text { szám, } 2010\end{array}$ & $\begin{array}{l}\text { Népes- } \\
\text { ség }\end{array}$ & $\begin{array}{l}\text { Társa- } \\
\text { dalom }\end{array}$ & $\begin{array}{l}\text { Társa- } \\
\text { dalom } \\
\text { (2011) }\end{array}$ & Ellátottság & Gazdaság & $\begin{array}{l}\text { Közle- } \\
\text { kedés }\end{array}$ & $\begin{array}{l}\text { Idegen- } \\
\text { forgalom }\end{array}$ & $\begin{array}{l}\text { Összfej- } \\
\text { lettség }\end{array}$ & $\begin{array}{c}\begin{array}{c}\text { H. Apró- } \\
\text { falu }\end{array} \\
\end{array}$ & $\begin{array}{c}\begin{array}{c}\text { H. Fal- } \\
\text { vak }\end{array} \\
\end{array}$ \\
\hline Répceszemere & 306 & 180,59 & 58,79 & 63,94 & 187,81 & 236,12 & 101,51 & 26,02 & 790,84 & 542 & 2175 \\
\hline Répceszentgyörgy & 115 & 197,06 & 93,63 & 97,45 & 207,63 & 250,53 & 185,08 & 41,01 & 974,94 & 108 & 665 \\
\hline Répcevis & 379 & 203,35 & 66,60 & 80,00 & 242,38 & 244,75 & 107,30 & 6,47 & 870,85 & 289 & 1490 \\
\hline Resznek & 308 & 172,64 & 39,88 & 50,23 & 244,10 & 208,00 & 170,86 & 19,23 & 854,71 & 326 & 1644 \\
\hline Rigács & 197 & 207,04 & 28,90 & 38,53 & 150,51 & 176,66 & 156,69 & 47,71 & 767,51 & 620 & 2319 \\
\hline Rigyác & 413 & 199,86 & 33,04 & 52,86 & 171,48 & 253,04 & 173,39 & 20,87 & 851,69 & 335 & 1666 \\
\hline Rinyabesenyő & 199 & 199,72 & 31,84 & 27,80 & 80,43 & 80,66 & 143,70 & 0,00 & 536,35 & 1063 & 2926 \\
\hline Rinyakovácsi & 146 & 187,99 & 13,94 & 19,86 & 127,18 & 124,16 & 188,27 & 18,37 & 659,91 & 926 & 2778 \\
\hline Rinyaszentkirály & 417 & 206,79 & 18,88 & 23,52 & 96,52 & 143,01 & 140,26 & 17,78 & 623,23 & 993 & 2850 \\
\hline Rinyaújlak & 285 & 195,38 & 47,00 & 56,82 & 199,53 & 176,71 & 150,68 & 24,18 & 793,48 & 531 & 2146 \\
\hline Rinyaújnép & 61 & 171,53 & 4,57 & 35,89 & 161,16 & 103,64 & 117,01 & 0,00 & 557,92 & 1055 & 2917 \\
\hline Romonya & 475 & 262,06 & 65,20 & 98,02 & 131,07 & 237,76 & 212,97 & 14,61 & 923,67 & 172 & 1024 \\
\hline$\overline{R o ́ z s a f a}$ & 408 & 213,89 & 53,45 & 55,03 & 130,39 & 184,20 & 187,68 & 18,02 & 787,65 & 555 & 2201 \\
\hline Röjtökmuzsaj & 437 & 207,03 & 56,42 & 59,50 & 234,47 & 253,70 & 140,61 & 149,26 & 1041,50 & 53 & 332 \\
\hline Rönök & 440 & 204,46 & 53,70 & 60,62 & 197,31 & 157,76 & 178,55 & 36,12 & 827,90 & 410 & 1878 \\
\hline Sajógalgóc & 394 & 241,99 & 66,62 & 92,26 & 149,31 & 205,48 & 181,00 & 0,00 & 844,39 & 361 & 1733 \\
\hline Sajóivánka & 647 & 244,77 & 88,07 & 94,28 & 185,88 & 215,66 & 233,36 & 3,79 & 971,52 & 110 & 684 \\
\hline Sajókápolna & 417 & 207,99 & 46,99 & 58,37 & 173,12 & 188,86 & 190,82 & 5,88 & 813,66 & 459 & 1993 \\
\hline Sajólászlófalva & 464 & 215,38 & 47,43 & 53,92 & 151,00 & 200,70 & 184,75 & 5,28 & 804,54 & 489 & 2055 \\
\hline Sajómercse & 249 & 190,88 & 45,69 & 50,75 & 73,81 & 139,08 & 160,03 & 3,73 & 613,21 & 1003 & 2863 \\
\hline Sajósenye & 449 & 234,55 & 57,06 & 72,79 & 200,28 & 208,00 & 192,69 & 16,38 & 908,96 & 202 & 1157 \\
\hline Sajtoskál & 418 & 207,46 & 46,83 & 58,62 & 161,17 & 242,95 & 175,14 & 36,46 & 870,02 & 293 & 1502 \\
\hline Salföld & 74 & 223,81 & 167,34 & 217,57 & 142,30 & 232,30 & 173,41 & 206,64 & 1145,79 & 17 & 112 \\
\hline Salköveskút & 488 & 289,68 & 47,17 & 67,96 & 220,28 & 242,77 & 206,05 & 15,45 & 1021,40 & 70 & 419 \\
\hline Sámod & 201 & 200,55 & 38,75 & 49,02 & 123,45 & 151,97 & 157,23 & 12,19 & 684,14 & 871 & 2704 \\
\hline Sámsonháza & 270 & 202,85 & 145,07 & 114,24 & 138,39 & 190,98 & 194,23 & 20,00 & 891,51 & 238 & 1287 \\
\hline Sand & 416 & 179,19 & 36,79 & 42,53 & 98,36 & 255,69 & 147,29 & 18,69 & 736,02 & 730 & 2511 \\
\hline Sárazsadány & 272 & 194,28 & 42,93 & 58,29 & 208,55 & 166,96 & 154,61 & 65,05 & 832,39 & 398 & 1843 \\
\hline Sárfimizdó & 100 & 190,46 & 62,80 & 88,62 & 104,39 & 257,60 & 174,47 & 30,07 & 819,79 & 433 & 1937 \\
\hline Sárkeszi & 606 & 244,80 & 50,87 & 54,11 & 179,05 & 219,16 & 193,09 & 8,09 & 895,07 & 232 & 1267 \\
\hline Sárok & 132 & 156,91 & 19,29 & 60,09 & 113,38 & 190,95 & 146,09 & 15,78 & 642,39 & 964 & 2817 \\
\hline Sáska & 297 & 241,99 & 46,16 & 50,56 & 175,45 & 216,72 & 178,01 & 32,11 & 890,45 & 244 & 1301 \\
\hline Selyeb & 496 & 239,75 & 38,14 & 33,14 & 144,96 & 127,97 & 151,62 & 14,94 & 717,39 & 780 & 2581 \\
\hline Semjén & 522 & 247,52 & 30,57 & 30,48 & 124,70 & 143,95 & 111,49 & 0,00 & 658,24 & 932 & 2784 \\
\hline Sénye & 51 & 244,90 & 74,72 & 96,38 & 162,36 & 246,56 & 196,37 & 10,89 & 935,79 & 154 & 922 \\
\hline Sérsekszölös & 166 & 201,89 & 44,04 & 67,82 & 98,49 & 235,10 & 168,95 & 0,00 & 748,47 & 689 & 2438 \\
\hline Sikátor & 345 & 209,60 & 29,59 & 51,34 & 154,86 & 205,85 & 163,61 & 34,94 & 798,45 & 512 & 2107 \\
\hline Siklósbodony & 153 & 241,22 & 26,40 & 33,01 & 116,16 & 150,97 & 157,82 & 16,02 & 708,60 & 810 & 2621 \\
\hline Siklósnagyfalu & 450 & 253,95 & 19,35 & 20,92 & 65,21 & 82,69 & 166,75 & 16,34 & 604,29 & 1019 & 2879 \\
\hline Sima & 36 & 285,36 & 98,44 & 235,32 & 47,82 & 214,90 & 125,87 & 210,00 & 982,39 & 100 & 620 \\
\hline Simonfa & 370 & 210,16 & 57,65 & 78,07 & 246,33 & 201,39 & 203,32 & 13,25 & 932,11 & 158 & 952 \\
\hline$\overline{\text { Siójut }}$ & 623 & 260,65 & 56,93 & 74,30 & 167,64 & 212,79 & 161,34 & 22,26 & 881,61 & 267 & 1386 \\
\hline Sobor & 291 & 175,08 & 36,74 & 47,03 & 164,03 & 268,08 & 154,33 & 18,73 & 816,99 & 442 & 1962 \\
\hline Sóly & 479 & 305,72 & 76,25 & 109,28 & 172,93 & 245,53 & 213,32 & 43,64 & 1057,38 & 40 & 277 \\
\hline Somlójenö & 328 & 222,11 & 23,75 & 35,20 & 102,57 & 170,57 & 164,12 & 68,71 & 751,83 & 677 & 2420 \\
\hline Somlóvecse & 110 & 216,05 & 43,26 & 72,66 & 128,65 & 251,05 & 144,52 & 27,47 & 811,00 & 464 & 2009 \\
\hline Somodor & 444 & 206,64 & 51,18 & 66,02 & 131,15 & 160,29 & 165,00 & 11,04 & 725,30 & 760 & 2555 \\
\hline Somogyacsa & 215 & 154,37 & 35,50 & 50,34 & 156,80 & 140,98 & 142,62 & 11,40 & 641,67 & 966 & 2819 \\
\hline Somogyaracs & 226 & 232,51 & 24,31 & 17,74 & 133,88 & 42,33 & 126,82 & 0,00 & 559,85 & 1053 & 2915 \\
\hline Somogybükkösd & 108 & 182,12 & 47,45 & 62,59 & 102,80 & 215,37 & 148,42 & 0,00 & 696,17 & 846 & 2669 \\
\hline Somogycsicsó & 178 & 165,21 & 26,16 & 43,23 & 136,49 & 164,52 & 151,58 & 13,77 & 657,74 & 934 & 2786 \\
\hline Somogydöröcske & 169 & 167,30 & 45,90 & 49,62 & 126,34 & 144,71 & 151,17 & 14,50 & 649,92 & 952 & 2805 \\
\hline Somogyegres & 227 & 181,07 & 34,73 & 46,04 & 120,23 & 203,13 & 143,73 & 10,80 & 693,70 & 854 & 2677 \\
\hline Somogyfajsz & 558 & 232,08 & 61,40 & 73,63 & 131,21 & 196,56 & 162,69 & 4,39 & 788,33 & 551 & 2194 \\
\hline Somogyhárságy & 466 & 189,70 & 56,09 & 71,62 & 176,48 & 175,46 & 157,09 & 29,10 & 783,92 & 576 & 2236 \\
\hline Somogyhatvan & 401 & 203,79 & 32,87 & 41,17 & 130,87 & 168,75 & 170,87 & 12,22 & 719,39 & 776 & 2576 \\
\hline Somogysimonyi & 99 & 214,55 & 49,99 & 104,27 & 177,90 & 216,07 & 135,76 & 48,56 & 842,83 & 364 & 1746 \\
\hline Somogytúr & 464 & 228,75 & 34,60 & 49,85 & 174,53 & 191,80 & 157,63 & 45,61 & 832,92 & 394 & 1838 \\
\hline Somogyviszló & 260 & 211,72 & $\mid 15,17$ & 32,39 & 124,94 & 126,07 & 170,05 & 9,43 & 657,38 & 935 & 2788 \\
\hline Sopronnémeti & 274 & 219,15 & 61,78 & 72,96 & 167,65 & 280,48 & 190,23 & 73,15 & 992,44 & 91 & 564 \\
\hline Sorkikápolna & 275 & 223,28 & 35,87 & 63,56 & 204,52 & 262,14 & 184,85 & 10,09 & 920,76 & 178 & 1052 \\
\hline Sóstófalva & 281 & 212,55 & 47,36 & 52,40 & 142,57 & 183,30 & 147,82 & 8,72 & 742,32 & 706 & 2474 \\
\hline Sósvertike & 193 & 195,61 & 13,59 & 30,63 & 101,45 & 85,15 & 159,64 & 35,37 & 590,81 & 1033 & 2893 \\
\hline Söréd & 535 & 327,19 & 76,46 & 93,51 & 210,27 & 253,86 & 219,41 & 29,16 & 1116,36 & 22 & 151 \\
\hline Sumony & 489 & 205,15 & 11,50 & 13,28 & 120,27 & 117,31 & 167,63 & 15,01 & 636,88 & 978 & 2832 \\
\hline Szabadi & 323 & 198,20 & 59,08 & 62,00 & 98,87 & 165,91 & 168,74 & 17,59 & 708,39 & 811 & 2622 \\
\hline Szabolcs & 382 & 205,08 & 60,70 & 76,07 & 219,02 & 218,28 & 114,79 & 82,08 & 899,94 & 219 & 1230 \\
\hline Szágy & 157 & 166,37 & 25,87 & 63,20 & 48,68 & 116,32 & 154,98 & 36,39 & 548,60 & 1060 & 2922 \\
\hline Szakácsi & 170 & 271,79 & 4,34 & 11,38 & 24,15 & 116,75 & 157,34 & 10,00 & 584,37 & 1038 & 2899 \\
\hline Szakadát & 277 & 170,81 & 120,19 & 125,02 & 144,09 & 211,96 & 149,18 & 13,03 & 809,26 & 470 & 2023 \\
\hline Szaknyér & 57 & 165,18 & 36,25 & 38,82 & 90,16 & 224,70 & 168,89 & 14,87 & 700,05 & 833 & 2652 \\
\hline
\end{tabular}




\begin{tabular}{|c|c|c|c|c|c|c|c|c|c|c|c|}
\hline Településnév & $\begin{array}{l}\text { Népesség- } \\
\text { szám, } 2010\end{array}$ & $\begin{array}{l}\text { Népes- } \\
\text { ség }\end{array}$ & $\begin{array}{l}\text { Társa- } \\
\text { dalom }\end{array}$ & $\begin{array}{l}\text { Társa- } \\
\text { dalom } \\
(2011)\end{array}$ & Ellátottság & Gazdaság & $\begin{array}{l}\text { Közle- } \\
\text { kedés }\end{array}$ & $\begin{array}{l}\text { Idegen- } \\
\text { forgalom }\end{array}$ & $\begin{array}{l}\text { Összfej- } \\
\text { lettség }\end{array}$ & $\begin{array}{c}\begin{array}{c}\text { H. Apró- } \\
\text { falu }\end{array} \\
\end{array}$ & $\begin{array}{c}\text { H. Fal- } \\
\text { vak }\end{array}$ \\
\hline Szakony & 447 & 185,70 & 63,36 & 79,24 & 233,19 & 250,96 & 104,60 & 7,73 & 845,53 & 356 & 1722 \\
\hline Szakonyfalu & 388 & 220,89 & 85,22 & 106,30 & 118,10 & 197,23 & 165,77 & 27,65 & 814,88 & 453 & 1977 \\
\hline Szalafö & 224 & 211,08 & 73,86 & 86,65 & 173,40 & 253,95 & 178,04 & 133,34 & 1023,68 & 66 & 406 \\
\hline Szalapa & 221 & 182,97 & 23,50 & 30,13 & 107,10 & 208,35 & 181,50 & 28,27 & 731,69 & 743 & 2530 \\
\hline Szalatnak & 371 & 176,91 & 70,49 & 56,56 & 198,86 & 185,94 & 154,56 & 6,61 & 793,37 & 532 & 2147 \\
\hline Szamosbecs & 377 & 199,93 & 36,59 & 57,72 & 204,72 & 225,85 & 149,11 & 23,00 & 839,21 & 375 & 1777 \\
\hline Szamoskér & 446 & 196,51 & 34,89 & 42,96 & 147,93 & 192,09 & 170,40 & 15,50 & 757,32 & 658 & 2393 \\
\hline Szamostatárfalva & 319 & 216,70 & 19,78 & 24,08 & 168,91 & 164,12 & 132,92 & 27,68 & 730,11 & 745 & 2533 \\
\hline Szamosújlak & 419 & 197,17 & 45,56 & 58,49 & 211,94 & 271,56 & 143,15 & 31,70 & 901,09 & 214 & 1215 \\
\hline \begin{tabular}{|l} 
Szántód \\
\end{tabular} & 630 & 317,13 & 143,18 & 126,01 & 356,35 & 270,62 & 205,62 & 277,73 & 1570,63 & 1 & 1 \\
\hline Szaporca & 271 & 209,20 & 18,39 & 27,05 & 60,27 & 168,68 & 154,63 & 47,73 & 658,91 & 929 & 2781 \\
\hline Szárász & 51 & 115,00 & 38,95 & 53,15 & 92,97 & 184,91 & 128,24 & 3,63 & 563,70 & 1051 & 2913 \\
\hline Szárazd & 256 & 205,52 & 77,21 & 69,80 & 121,95 & 172,45 & 144,07 & 19,52 & 740,72 & 711 & 2481 \\
\hline Szarvasgede & 427 & 204,52 & 36,19 & 49,93 & 164,00 & 219,86 & 182,53 & 18,99 & 826,08 & 412 & 1887 \\
\hline Szarvaskend & 226 & 196,16 & 52,37 & 61,85 & 167,94 & 267,67 & 188,30 & 28,01 & 900,45 & 215 & 1222 \\
\hline Szászfa & 144 & 164,48 & 8,94 & 23,87 & \begin{tabular}{c|c|}
62,45 \\
\end{tabular} & 52,90 & 111,49 & 0,00 & 400,26 & 1072 & 2935 \\
\hline Szatta & 83 & 207,99 & 141,20 & 159,32 & 83,83 & 256,29 & 180,11 & 110,00 & 979,43 & 102 & 638 \\
\hline Szava & 364 & 231,48 & 20,15 & 40,32 & 106,80 & 189,24 & 179,92 & 16,73 & 744,33 & 700 & 2464 \\
\hline Szebény & 433 & 187,16 & 57,92 & 70,06 & 128,50 & 177,87 & 137,57 & 22,64 & 711,65 & 801 & 2608 \\
\hline Szécsénke & 219 & 164,01 & 52,99 & 63,00 & 264,60 & 248,90 & 115,99 & 11,19 & 857,67 & 319 & 1612 \\
\hline Szécsényfelfalu & 462 & 203,98 & 47,73 & 55,87 & 184,47 & 184,75 & 188,50 & 24,38 & 833,81 & 392 & 1831 \\
\hline Szécsisziget & 239 & 182,81 & 66,50 & 80,77 & 180,27 & 221,54 & 175,86 & 60,62 & 887,60 & 252 & 1325 \\
\hline Szegerdő & 226 & 192,56 & 10,40 & 22,88 & 143,08 & 140,09 & 126,08 & 20,85 & 633,06 & 982 & 2836 \\
\hline Szegi & 342 & 220,83 & 52,89 & 60,24 & 180,08 & 218,44 & 167,09 & 34,33 & 873,65 & 284 & 1472 \\
\hline Szegilong & 252 & 202,34 & 59,38 & 63,51 & 178,61 & 222,19 & 153,13 & 20,78 & 836,43 & 386 & 1801 \\
\hline Szellö & 146 & 177,02 & 62,88 & 77,38 & 113,05 & 222,29 & 186,72 & 30,12 & 792,08 & 539 & 2162 \\
\hline Szemely & 490 & 263,45 & 100,19 & 99,89 & 109,43 & 217,27 & 189,41 & 15,89 & 895,65 & 228 & 1262 \\
\hline Szemenye & 314 & 190,81 & 36,12 & 48,51 & 208,34 & 233,17 & 183,34 & 29,03 & 880,81 & 268 & 1397 \\
\hline Szemere & 386 & 240,95 & 72,77 & 67,31 & 171,49 & 97,96 & 141,15 & 25,05 & 749,37 & 686 & 2435 \\
\hline Szenta & 441 & 199,95 & 45,55 & 51,09 & 100,96 & 196,85 & 151,09 & 7,84 & 702,24 & 828 & 2645 \\
\hline Szentantalfa & 454 & 249,38 & 79,40 & 97,16 & 197,74 & 261,63 & 161,81 & 100,67 & 1050,62 & 48 & 300 \\
\hline Szentbalázs & 340 & 196,64 & 136,26 & 126,16 & 168,23 & 226,48 & 192,66 & 34,08 & 954,35 & 126 & 789 \\
\hline Szentbékkálla & 219 & 194,97 & 107,26 & 134,04 & 130,20 & 232,20 & 183,55 & 151,15 & 999,33 & 88 & 529 \\
\hline Szentborbás & 145 & 212,43 & 83,19 & 98,12 & 117,01 & 101,76 & 110,14 & 26,90 & 651,43 & 947 & 2800 \\
\hline Szentdénes & 333 & 214,34 & 41,64 & 43,49 & 117,32 & 151,45 & 183,03 & 22,08 & 729,86 & 747 & 2536 \\
\hline Szentdomonkos & 481 & 181,13 & 45,84 & 50,72 & 164,01 & 194,00 & 188,48 & 22,90 & 796,36 & 519 & 2123 \\
\hline Szente & 368 & 206,61 & 43,03 & 61,80 & 162,98 & 235,39 & 147,40 & 8,37 & 803,78 & 493 & 2064 \\
\hline Szentegát & 430 & 217,18 & 49,04 & 56,41 & 192,85 & 144,23 & 178,26 & 6,27 & 787,83 & 554 & 2199 \\
\hline Szentgyörgyvár & 331 & 217,77 & 40,13 & 61,72 & 164,33 & 204,45 & 190,40 & 56,89 & 873,96 & 283 & 1470 \\
\hline Szentgyörgyvölgy & 456 & 193,33 & 66,24 & 74,50 & 135,45 & 224,78 & 150,04 & 80,51 & 850,35 & 338 & 1676 \\
\hline Szentimrefalva & 229 & 215,34 & 28,10 & 32,72 & 124,74 & 210,77 & 165,90 & 12,43 & 757,27 & 659 & 2394 \\
\hline Szentistvánbaksa & 285 & 210,36 & 20,01 & 45,05 & 112,26 & 182,84 & 169,69 & 18,60 & 713,75 & 797 & 2602 \\
\hline Szentjakabfa & 114 & 193,14 & 108,77 & 167,41 & 138,31 & 249,06 & 170,85 & 162,74 & 1022,88 & 67 & 412 \\
\hline Szentkatalin & 135 & 187,55 & 52,26 & 57,09 & 64,82 & 167,19 & 168,14 & 30,43 & 670,41 & 896 & 2743 \\
\hline Szentkozmadombja & 63 & 123,97 & 20,16 & 56,49 & 262,18 & 199,05 & 170,78 & 185,06 & 961,19 & 119 & 745 \\
\hline Szentliszló & 319 & 191,97 & 39,60 & 51,35 & 141,72 & 224,50 & 159,68 & 34,13 & 791,59 & 541 & 2167 \\
\hline Szentmargitfalva & 95 & 163,30 & 47,86 & 65,55 & 102,14 & 138,30 & 157,60 & 31,65 & 640,85 & 968 & 2821 \\
\hline Szentpéterfölde & 157 & 189,74 & 22,53 & 31,63 & 108,45 & 201,59 & 142,87 & 53,50 & 718,67 & 779 & 2579 \\
\hline Szenyér & 342 & 212,13 & 38,92 & 51,73 & 88,61 & 115,28 & 163,95 & 0,00 & 618,89 & 997 & 2856 \\
\hline Szergény & 361 & 183,87 & 38,51 & 60,43 & 140,75 & 243,94 & 150,88 & 20,82 & 778,77 & 592 & 2269 \\
\hline Szijártóháza & 29 & 95,21 & 26,63 & 22,59 & 154,10 & 134,94 & 163,74 & 23,95 & 598,56 & 1021 & 2881 \\
\hline Szilágy & 307 & 197,34 & 36,73 & 62,13 & 91,16 & 209,91 & 196,53 & 21,00 & 752,67 & 672 & 2415 \\
\hline Szilaspogony & 329 & 183,20 & 23,45 & 32,56 & 170,93 & 123,32 & 159,33 & 15,69 & 675,92 & 888 & 2728 \\
\hline Szilvágy & 203 & 184,86 & 41,77 & 57,94 & 163,33 & 244,75 & 175,35 & 78,97 & 889,03 & 247 & 1313 \\
\hline Szilvás & 170 & 211,72 & 37,75 & 47,63 & 112,74 & 198,37 & 184,29 & 4,90 & 749,77 & 685 & 2434 \\
\hline Szilvásszentmárton & 209 & 198,33 & 28,86 & 44,31 & 31,91 & 214,12 & 162,07 & 23,45 & 658,75 & 930 & 2782 \\
\hline Szinpetri & 262 & 210,74 & 25,96 & 32,18 & 80,98 & 164,41 & 122,12 & 29,35 & 633,56 & 981 & 2835 \\
\hline Szorosad & 112 & 170,45 & 63,97 & 89,81 & 126,53 & 255,13 & 161,35 & 21,88 & 799,32 & 509 & 2100 \\
\hline Szöc & 446 & 189,84 & 17,14 & 24,58 & 79,02 & 187,60 & 177,99 & 22,96 & 674,55 & 891 & 2732 \\
\hline Szöce & 370 & 185,48 & 54,92 & 74,30 & 173,37 & 219,84 & 172,24 & 43,33 & 849,18 & 343 & 1685 \\
\hline Szőke & 146 & 196,08 & 24,12 & 20,88 & 55,51 & 110,54 & 172,03 & 0,00 & 558,27 & 1054 & 2916 \\
\hline Szökéd & 397 & 214,25 & 41,04 & 45,10 & 150,00 & 198,09 & 178,89 & 22,35 & 804,62 & 488 & 2054 \\
\hline Szökedencs & 301 & 165,89 & 27,17 & 38,91 & 143,72 & 187,39 & 137,29 & 38,14 & 699,60 & 836 & 2656 \\
\hline Szölösardó & 142 & 181,53 & 34,72 & 41,49 & 182,72 & 207,72 & 135,89 & 64,74 & 807,32 & 476 & 2034 \\
\hline Szörény & 75 & 186,45 & 59,85 & 95,54 & 101,00 & 224,75 & 155,17 & 0,00 & 727,23 & 754 & 2545 \\
\hline Szúcs & 457 & 223,72 & 23,01 & 26,04 & 82,11 & 130,18 & 174,06 & 13,06 & 646,13 & 954 & 2807 \\
\hline Szuhafö & 170 & 180,50 & 40,51 & 54,63 & 139,14 & 188,76 & 136,32 & 30,00 & 715,23 & 792 & 2597 \\
\hline Szulimán & 260 & 167,94 & 16,24 & 34,55 & 88,18 & 176,13 & 173,48 & 18,85 & 640,82 & 969 & 2822 \\
\hline Szür & 302 & 191,50 & 75,98 & 83,47 & 163,54 & 195,05 & 169,80 & 43,98 & 839,85 & 372 & 1769 \\
\hline Tagyon & 99 & 246,39 & 57,15 & 134,01 & 126,80 & 215,49 & 171,68 & 55,43 & 872,95 & 286 & 1477 \\
\hline Tákos & 360 & 275,71 & 46,14 & 69,71 & 197,91 & 219,80 & 165,46 & 46,01 & 951,03 & 132 & 806 \\
\hline
\end{tabular}




\begin{tabular}{|c|c|c|c|c|c|c|c|c|c|c|c|}
\hline Településnév & $\begin{array}{l}\text { Népesség- } \\
\text { szám, } 2010\end{array}$ & $\begin{array}{l}\text { Népes- } \\
\text { ség }\end{array}$ & $\begin{array}{l}\text { Társa- } \\
\text { dalom }\end{array}$ & $\begin{array}{l}\text { Társa- } \\
\text { dalom } \\
\text { (2011) }\end{array}$ & Ellátottság & Gazdaság & $\begin{array}{l}\text { Közle- } \\
\text { kedés }\end{array}$ & $\begin{array}{l}\text { Idegen- } \\
\text { forgalom }\end{array}$ & $\begin{array}{l}\text { Összfej- } \\
\text { lettség }\end{array}$ & $\begin{array}{c}\begin{array}{c}\text { H. Apró- } \\
\text { falu }\end{array} \\
\end{array}$ & $\begin{array}{c}\begin{array}{c}\text { H. Fal- } \\
\text { vak }\end{array} \\
\end{array}$ \\
\hline Tarjánpuszta & 406 & 241,27 & 45,30 & 60,81 & 221,15 & 234,44 & 196,38 & 10,00 & 948,55 & 135 & 820 \\
\hline Tarnaszentmária & 245 & 166,95 & 38,78 & 54,02 & 164,79 & 211,37 & 151,69 & 43,45 & 777,03 & 597 & 2277 \\
\hline Tárnokréti & 210 & 197,75 & 55,49 & 79,77 & 77,58 & 239,10 & 181,05 & 30,18 & 781,15 & 583 & 2251 \\
\hline Tarrós & 131 & 241,64 & 35,67 & 47,73 & 132,59 & 201,45 & 181,93 & 18,71 & 811,99 & 462 & 2004 \\
\hline Táska & 440 & 191,06 & 38,75 & 46,62 & 128,19 & 200,39 & 155,23 & 21,14 & 734,75 & 733 & 2517 \\
\hline Tékes & 279 & 213,63 & 27,24 & 23,92 & 117,00 & 121,55 & 169,09 & 8,78 & 657,29 & 937 & 2790 \\
\hline Teklafalu & 359 & 198,82 & 40,03 & 58,86 & 107,70 & 182,49 & 160,60 & 20,48 & 710,12 & 805 & 2614 \\
\hline Teleki & 222 & 219,93 & 49,10 & 60,34 & 122,49 & 157,53 & 153,84 & 35,64 & 738,53 & 719 & 2496 \\
\hline Tengeri & 73 & 197,72 & 32,81 & 31,71 & 95,66 & 174,62 & 155,14 & 0,00 & 655,94 & 940 & 2793 \\
\hline Tengöd & 485 & 184,81 & 37,11 & 49,49 & 187,08 & 174,10 & 154,29 & 10,11 & 747,49 & 695 & 2448 \\
\hline Terény & 413 & 206,08 & \begin{tabular}{l|l|}
93,32 \\
\end{tabular} & 111,90 & 167,29 & 232,25 & 141,32 & 19,04 & 859,29 & 317 & 1598 \\
\hline Teresztenye & 31 & 192,57 & 76,91 & 113,96 & 262,84 & 334,36 & 153,37 & 130,00 & 1150,05 & 16 & 109 \\
\hline Terpes & 215 & 216,86 & 18,92 & 28,49 & 95,07 & 108,06 & 191,14 & 0,00 & 630,04 & 986 & 2840 \\
\hline Tésa & 93 & 160,11 & 39,50 & 59,82 & 200,83 & 237,98 & 101,64 & 46,35 & 786,42 & 564 & 2216 \\
\hline Tésenfa & 207 & 188,80 & 19,60 & 31,23 & 113,15 & 138,18 & 155,73 & 41,76 & 657,22 & 938 & 2791 \\
\hline Téseny & 344 & 233,04 & 11,12 & 13,07 & 113,11 & 141,13 & 153,12 & 7,12 & 658,65 & 931 & 2783 \\
\hline Tikos & 133 & 206,37 & 11,11 & 8,74 & 96,81 & 69,75 & 129,73 & 10,00 & 523,78 & 1064 & 2927 \\
\hline Tilaj & 203 & 200,86 & 23,08 & 48,68 & 121,66 & 223,13 & 177,26 & 32,30 & 778,27 & 595 & 2272 \\
\hline Tiszabábolna & 407 & 171,29 & 48,66 & 61,20 & 295,97 & 203,08 & 132,96 & 71,14 & 923,11 & 173 & 1029 \\
\hline Tiszacsécse & 260 & 197,38 & 23,72 & 29,33 & 122,10 & 185,05 & 100,72 & 69,27 & 698,23 & 840 & 2662 \\
\hline Tiszadorogma & 428 & 174,35 & 47,55 & 58,55 & 217,16 & 222,61 & 146,52 & 52,91 & 861,10 & 314 & 1572 \\
\hline Tiszainoka & 440 & 209,87 & 35,09 & 46,84 & 148,98 & 194,57 & 157,17 & 21,88 & 767,57 & 619 & 2318 \\
\hline Tiszatardos & 269 & 187,91 & 42,33 & 51,56 & 114,88 & 191,51 & 172,36 & 28,22 & 737,22 & 727 & 2506 \\
\hline Tiszavalk & 332 & 187,25 & 55,62 & 68,45 & 229,73 & 238,46 & 136,82 & 64,10 & 911,99 & 198 & 1129 \\
\hline Tiszavid & 542 & 249,30 & 32,70 & 39,12 & 129,73 & 108,35 & 147,08 & 39,40 & 706,56 & 814 & 2628 \\
\hline Tivadar & 220 & 191,91 & 59,53 & 78,95 & 155,43 & 193,41 & 142,82 & 240,00 & 983,10 & 98 & 616 \\
\hline Tófü & 145 & 188,79 & 27,64 & 43,92 & 122,47 & 218,87 & 150,32 & 20,73 & 728,83 & 753 & 2542 \\
\hline Tokorcs & 357 & 303,82 & 48,39 & 79,15 & 186,88 & 258,67 & 193,14 & 15,60 & 1006,50 & 79 & 490 \\
\hline Told & 355 & 211,34 & 18,28 & 36,47 & 143,32 & 105,39 & 136,72 & 6,90 & 621,95 & 994 & 2852 \\
\hline Tomor & 248 & 192,26 & 53,44 & 71,32 & 134,38 & 162,96 & 164,40 & 9,88 & 717,32 & 781 & 2582 \\
\hline Tompaládony & 328 & 208,70 & 44,10 & 47,23 & 196,00 & 239,51 & 180,03 & 104,45 & 972,79 & 109 & 677 \\
\hline Tormafölde & 378 & 170,35 & 37,20 & 47,96 & 197,96 & 218,09 & 169,39 & 62,00 & 854,99 & 325 & 1639 \\
\hline Tormás & 337 & 200,47 & 50,02 & 69,84 & 164,34 & 169,87 & 171,54 & 30,32 & 786,56 & 562 & 2213 \\
\hline Tormásliget & 313 & 183,39 & 16,35 & 24,90 & 127,70 & 241,44 & 183,74 & 10,05 & 762,66 & 634 & 2354 \\
\hline Tornabarakony & 21 & 122,04 & 100,00 & 154,73 & 71,03 & 205,34 & 76,93 & 100,00 & 675,33 & 889 & 2729 \\
\hline Tornakápolna & 23 & 308,17 & 100,00 & 232,50 & 122,16 & 302,16 & 121,92 & 120,00 & 1074,41 & 33 & 223 \\
\hline Tornaszentandrás & 237 & 155,75 & 35,69 & 45,37 & 121,80 & 191,24 & 96,16 & 44,59 & 645,24 & 956 & 2809 \\
\hline Tornaszentjakab & 233 & 187,18 & 35,88 & 31,70 & 98,34 & 167,29 & 82,77 & 20,52 & 591,98 & 1031 & 2891 \\
\hline Torvaj & 292 & 179,36 & 26,13 & 38,74 & 137,44 & 149,93 & 158,85 & 16,79 & 668,50 & 901 & 2749 \\
\hline Tótszentgyörgy & 177 & 202,91 & 30,43 & 39,01 & 110,80 & 166,72 & 179,46 & 13,85 & 704,16 & 821 & 2637 \\
\hline Tótúffalu & 243 & 183,47 & 91,07 & 95,39 & 129,90 & 162,89 & 126,38 & 39,47 & 733,19 & 739 & 2525 \\
\hline Tömörd & 271 & 225,55 & 85,84 & 112,67 & 182,76 & 250,14 & 205,37 & 16,05 & 965,71 & 115 & 717 \\
\hline Törökkoppány & 441 & 191,95 & 99,95 & 100,91 & 194,37 & 217,23 & 154,38 & 31,12 & 888,99 & 248 & 1314 \\
\hline Trizs & 252 & 177,54 & 36,48 & 51,53 & 117,94 & 219,10 & 139,25 & 39,45 & 729,78 & 748 & 2537 \\
\hline Túrony & 283 & 224,40 & 60,66 & 78,22 & 111,03 & 225,99 & 212,51 & 49,92 & 884,51 & 260 & 1357 \\
\hline Udvar & 165 & 171,46 & 155,30 & 135,73 & 213,55 & 233,32 & 206,90 & 10,00 & 990,53 & 92 & 578 \\
\hline Udvari & 367 & 161,09 & 38,12 & 35,05 & 125,84 & 163,38 & 120,61 & 21,04 & 630,09 & 985 & 2839 \\
\hline Újbarok & 439 & 303,50 & 103,24 & 140,62 & 161,09 & 241,10 & 188,59 & 5,58 & 1003,10 & 85 & 507 \\
\hline Újireg & 318 & 192,17 & 36,18 & 46,89 & 108,35 & 216,16 & 157,76 & 23,12 & 733,73 & 738 & 2524 \\
\hline Újlörincfalva & 248 & 184,74 & 50,63 & 57,84 & 217,39 & 191,95 & 149,18 & 68,83 & 862,70 & 311 & 1560 \\
\hline Újsolt & 182 & 192,31 & 22,32 & 33,44 & 132,93 & 209,34 & 111,64 & 42,35 & 710,89 & 804 & 2612 \\
\hline Újszalonta & 116 & 175,58 & 57,11 & 70,64 & 198,31 & 169,61 & 163,64 & 21,13 & 785,38 & 570 & 2223 \\
\hline Újtelek & 425 & 164,33 & 46,65 & 46,67 & 178,43 & 230,66 & 150,14 & 17,30 & 787,52 & 556 & 2202 \\
\hline Újvárfalva & 312 & 187,36 & 43,67 & 59,16 & 76,78 & 176,78 & 162,39 & 17,86 & 664,83 & 912 & 2761 \\
\hline Ukk & 350 & 201,27 & 72,49 & 65,13 & 228,13 & 205,37 & 175,47 & 93,31 & 976,06 & 106 & 660 \\
\hline Und & 347 & 201,14 & 131,51 & 159,72 & 198,98 & 266,27 & 111,49 & 28,07 & 937,47 & 149 & 904 \\
\hline Uppony & 345 & 159,74 & 43,23 & 56,50 & \begin{tabular}{|l|}
170,53 \\
\end{tabular} & 196,67 & 161,78 & 20,94 & 752,89 & 670 & 2413 \\
\hline Uszka & 413 & 315,78 & 12,91 & 11,89 & 58,94 & 109,21 & 82,05 & 25,93 & 604,82 & 1018 & 2878 \\
\hline Uzsa & 356 & 188,98 & 52,62 & \begin{tabular}{|l|}
51,73 \\
\end{tabular} & 176,93 & 231,10 & 178,46 & 62,36 & 890,45 & 243 & 1300 \\
\hline Váckisújfalu & 479 & 235,92 & 63,47 & 83,83 & 138,26 & 226,61 & 180,56 & 5,25 & 850,08 & 339 & 1679 \\
\hline Vadosfa & 85 & 203,10 & 66,76 & 66,58 & 141,15 & 246,92 & 174,66 & 0,00 & 832,59 & 397 & 1841 \\
\hline Vágáshuta & 91 & 242,28 & 99,94 & \begin{tabular}{ll|}
111,80 \\
\end{tabular} & \begin{tabular}{|l|}
197,51 \\
\end{tabular} & 210,19 & 118,74 & 136,93 & 1005,59 & 82 & 495 \\
\hline Valkonya & 67 & 220,75 & 35,22 & 106,11 & 80,84 & 281,99 & 166,26 & 30,45 & 815,51 & 451 & 1975 \\
\hline Vállus & 144 & 202,47 & 71,74 & 76,40 & 120,48 & 253,81 & 165,24 & 42,86 & 856,60 & 321 & 1623 \\
\hline Vámoscsalád & 328 & 182,51 & 65,53 & 81,25 & 155,98 & 244,96 & 174,76 & 42,28 & 866,03 & 304 & 1532 \\
\hline Várad & 125 & 195,07 & 32,22 & 33,13 & 75,20 & 106,70 & 160,55 & 0,00 & 569,74 & 1045 & 2907 \\
\hline Varászló & 159 & 180,70 & 38,79 & 41,62 & 174,60 & 199,70 & 144,53 & 15,41 & 753,74 & 667 & 2409 \\
\hline Várbalog & 412 & 180,27 & 40,51 & 49,50 & 213,23 & 246,70 & 172,09 & 35,69 & 888,49 & 250 & 1318 \\
\hline Varbóc & 67 & 171,55 & 64,04 & 74,27 & 70,99 & 237,49 & 134,61 & 120,00 & 798,68 & 510 & 2105 \\
\hline Várfölde & 200 & 187,86 & 40,70 & 40,76 & 141,60 & 190,96 & 155,49 & 36,14 & 752,76 & 671 & 2414 \\
\hline Varga & 109 & 176,92 & 6,40 & 17,21 & 89,72 & 140,85 & 178,64 & 51,37 & 643,90 & 962 & 2815 \\
\hline
\end{tabular}




\begin{tabular}{|c|c|c|c|c|c|c|c|c|c|c|c|}
\hline Településnév & $\begin{array}{l}\text { Népesség- } \\
\text { szám, } 2010\end{array}$ & $\begin{array}{l}\text { Népes- } \\
\text { ség }\end{array}$ & $\begin{array}{l}\text { Társa- } \\
\text { dalom }\end{array}$ & $\begin{array}{l}\text { Társa- } \\
\text { dalom } \\
(2011)\end{array}$ & Ellátottság & Gazdaság & $\begin{array}{l}\text { Közle- } \\
\text { kedés }\end{array}$ & $\begin{array}{l}\text { Idegen- } \\
\text { forgalom }\end{array}$ & $\begin{array}{l}\text { Összfej- } \\
\text { lettség }\end{array}$ & $\begin{array}{c}\begin{array}{c}\text { H. Apró- } \\
\text { falu }\end{array} \\
\end{array}$ & $\begin{array}{c}\text { H. Fal- } \\
\text { vak }\end{array}$ \\
\hline Várgesztes & 599 & 255,39 & 143,29 & 164,42 & 257,21 & 262,57 & 200,90 & 140,46 & 1259,82 & 9 & 44 \\
\hline Várkeszö & 194 & 177,57 & 40,70 & 49,36 & 140,79 & 220,12 & 125,01 & 12,63 & 716,83 & 784 & 2585 \\
\hline Várong & 168 & 157,23 & 24,10 & 33,45 & 72,45 & 159,72 & 127,74 & 70,21 & 611,45 & 1007 & 2867 \\
\hline Varsád & 407 & 202,36 & 51,32 & 53,69 & 121,85 & 177,28 & 135,92 & 23,42 & 712,14 & 800 & 2607 \\
\hline Vasalja & 341 & 216,19 & 74,82 & 70,01 & 180,15 & 231,36 & 194,03 & 39,96 & 936,51 & 150 & 911 \\
\hline Vásárosbéc & 194 & 175,87 & $\begin{array}{ll}15,47 \\
\end{array}$ & 40,42 & 100,02 & 160,99 & 159,95 & 0,00 & 612,29 & 1005 & 2865 \\
\hline Vásárosfalu & 178 & 249,49 & 74,75 & 76,63 & 165,86 & 271,50 & 161,73 & 14,65 & 937,97 & 148 & 899 \\
\hline Vásárosmiske & 358 & 198,83 & 47,02 & 55,73 & 139,45 & 251,86 & 176,41 & 23,00 & 836,58 & 385 & 1800 \\
\hline Vasasszonyfa & 367 & 204,28 & 43,05 & 59,04 & 238,89 & 262,69 & 210,19 & 21,59 & 980,69 & 101 & 629 \\
\hline Vasegerszeg & 399 & 200,95 & 81,22 & 76,06 & 140,68 & 240,03 & 176,84 & 42,33 & 882,05 & 266 & 1381 \\
\hline Vashosszúfalu & 397 & 173,38 & 37,35 & 42,68 & 169,37 & 234,48 & 166,73 & 24,94 & 806,24 & 481 & 2043 \\
\hline Vaskeresztes & 357 & 234,50 & 138,19 & 163,88 & 191,72 & 253,10 & 192,04 & 37,66 & 1047,21 & 49 & 309 \\
\hline Vaspör & 395 & 185,48 & 40,49 & 61,13 & 117,50 & 223,32 & 176,49 & 26,51 & 769,79 & 612 & 2309 \\
\hline Vászoly & 258 & 248,03 & 41,63 & 81,53 & 234,50 & 208,29 & 186,28 & 43,05 & 961,78 & 117 & 738 \\
\hline Vasszentmihály & 354 & 230,55 & 88,70 & 65,60 & 200,23 & 258,72 & 177,57 & 46,98 & 1002,74 & 86 & 510 \\
\hline Vasszilvágy & 426 & 208,30 & 76,33 & 48,04 & 120,02 & 245,44 & 189,48 & 45,60 & 885,17 & 258 & 1349 \\
\hline Vázsnok & 134 & 171,90 & 47,28 & 58,24 & 86,94 & 216,52 & 191,41 & 37,91 & 751,97 & 676 & 2419 \\
\hline Vejti & 180 & 187,65 & 27,92 & 28,61 & 144,78 & 161,12 & 158,33 & 23,62 & 703,42 & 824 & 2641 \\
\hline Vékény & 149 & 192,70 & 33,41 & 38,73 & 133,29 & 181,86 & 172,60 & 37,61 & 751,46 & 681 & 2426 \\
\hline Vekerd & 135 & 161,85 & 50,69 & 34,34 & 138,83 & 205,40 & 134,71 & 31,36 & 722,84 & 767 & 2564 \\
\hline Velem & 356 & 228,96 & 103,98 & 129,69 & 215,81 & 277,55 & 209,01 & 237,54 & 1272,86 & 6 & 36 \\
\hline Velemér & 77 & 173,64 & 84,50 & 118,72 & 121,74 & 255,46 & 154,68 & 160,80 & 950,84 & 133 & 807 \\
\hline Velény & 172 & 216,61 & 38,03 & 36,10 & 96,52 & 148,11 & 185,61 & 28,78 & 713,66 & 798 & 2603 \\
\hline Vének & 191 & 260,18 & 82,27 & 78,73 & 144,73 & 235,17 & 188,64 & 72,02 & 983,01 & 99 & 618 \\
\hline Vértestolna & 525 & 227,88 & 98,54 & 128,49 & 259,67 & 249,21 & 197,32 & 36,21 & 1068,82 & 36 & 246 \\
\hline Veszprémfajsz & 258 & 231,55 & 84,82 & 97,42 & 157,76 & 257,72 & 221,30 & 60,09 & 1013,24 & 75 & 453 \\
\hline Veszprémgalsa & 286 & 208,86 & 46,85 & 48,08 & 149,65 & 216,51 & 163,40 & 36,84 & 822,10 & 426 & 1914 \\
\hline Vid & 161 & 231,46 & 23,21 & 28,92 & 89,97 & 170,33 & 137,40 & 31,26 & 683,64 & 874 & 2707 \\
\hline Vigántpetend & 224 & 230,01 & 93,69 & 106,36 & 154,62 & 188,12 & 184,52 & 80,46 & 931,42 & 159 & 954 \\
\hline Villánykövesd & 298 & 188,83 & 60,93 & 98,62 & 201,30 & 244,61 & 180,88 & 136,78 & 1013,33 & 74 & 451 \\
\hline Vilyvitány & 281 & 178,72 & 49,34 & 65,30 & 151,14 & 181,65 & 119,47 & 49,70 & 730,03 & 746 & 2534 \\
\hline Vinár & 253 & 210,45 & 54,98 & 55,09 & 161,45 & 219,68 & 142,80 & 13,35 & 802,72 & 496 & 2071 \\
\hline Vindornyafok & 141 & 209,21 & 41,68 & 68,91 & 207,12 & 237,14 & 182,77 & 12,63 & 890,54 & 242 & 1296 \\
\hline Vindornyalak & 102 & 238,61 & 20,95 & 46,97 & 142,32 & 181,88 & 159,15 & 44,18 & 787,10 & 558 & 2208 \\
\hline Vindornyaszölös & 354 & 201,85 & 32,82 & 43,41 & 223,69 & 209,10 & 177,37 & 42,35 & 887,17 & 253 & 1331 \\
\hline Visnye & 253 & 230,13 & 74,07 & 91,53 & 49,14 & 124,41 & 180,55 & 8,42 & 666,71 & 906 & 2754 \\
\hline Visz & 214 & 194,59 & 48,40 & 65,32 & 140,26 & 203,99 & 142,57 & 43,31 & 773,12 & 601 & 2289 \\
\hline Viszák & 271 & 182,71 & 67,45 & 84,39 & 147,11 & 272,79 & 183,41 & 22,29 & 875,75 & 280 & 1458 \\
\hline Viszló & 73 & 153,75 & 46,19 & 69,85 & 78,73 & 259,35 & 105,05 & 33,58 & 676,64 & 884 & 2723 \\
\hline Vöckönd & 84 & 172,54 & 51,40 & 76,77 & 184,53 & 252,16 & 188,16 & 14,33 & 863,12 & 309 & 1557 \\
\hline Völcsej & 372 & 203,05 & 78,68 & 74,74 & 197,08 & 271,24 & 135,12 & 13,18 & 898,35 & 221 & 1242 \\
\hline Vöröstó & 99 & 189,87 & 87,06 & 146,97 & 178,02 & 237,26 & 186,02 & 21,83 & 900,06 & 218 & 1226 \\
\hline Vörs & 489 & 206,71 & 42,53 & 62,44 & 220,06 & 193,45 & 174,41 & 55,01 & 892,17 & 235 & 1283 \\
\hline Zádor & 333 & 191,33 & 38,28 & 40,11 & 104,63 & 139,71 & 148,75 & 14,72 & 637,44 & 976 & 2830 \\
\hline Zádorfalva & 476 & 218,42 & 34,93 & 37,60 & 132,26 & 118,75 & 143,47 & 10,30 & 658,12 & 933 & 2785 \\
\hline Zajk & 251 & 196,22 & 20,24 & 29,10 & 65,60 & 121,98 & 152,23 & 22,36 & 578,62 & 1041 & 2903 \\
\hline Zajta & 429 & 208,42 & 47,12 & 69,11 & 142,85 & 174,90 & 96,56 & 21,43 & 691,28 & 858 & 2685 \\
\hline Zala & 262 & 197,26 & 53,52 & 59,63 & 165,00 & 223,54 & 178,42 & 20,00 & 837,75 & 383 & 1790 \\
\hline Zalaboldogfa & 386 & 244,26 & 30,80 & 47,89 & 144,06 & 230,21 & 198,76 & 21,10 & 869,18 & 295 & 1505 \\
\hline Zalaerdőd & 327 & 190,15 & 27,15 & 35,75 & 117,61 & 192,50 & 143,59 & 24,19 & 695,20 & 848 & 2671 \\
\hline Zalagyömörö & 470 & 195,02 & 34,55 & 52,92 & 144,28 & 224,51 & 178,50 & 20,98 & 797,84 & 514 & 2112 \\
\hline Zalaháshágy & 384 & 190,33 & 60,88 & 70,43 & 139,65 & 256,13 & 184,81 & 46,23 & 878,03 & 274 & 1426 \\
\hline Zalaigrice & 138 & 198,42 & 17,50 & 28,66 & 117,03 & 185,23 & 195,30 & 1,34 & 714,82 & 793 & 2598 \\
\hline Zalaistvánd & 372 & 189,87 & 42,44 & 67,35 & 153,30 & 234,77 & 192,10 & 43,56 & 856,05 & 322 & 1631 \\
\hline Zalaköveskút & 28 & 143,20 & 25,54 & 53,96 & 198,30 & 196,15 & 175,08 & 13,31 & 751,58 & 679 & 2424 \\
\hline Zalameggyes & 62 & 241,22 & 14,14 & 17,29 & 92,74 & 194,06 & 178,81 & 16,42 & 737,39 & 725 & 2504 \\
\hline Zalamerenye & 180 & 163,64 & 41,73 & 73,31 & 197,47 & 218,39 & 173,22 & 30,77 & 825,23 & 415 & 1893 \\
\hline Zalasárszeg & 130 & 262,20 & 48,64 & 53,24 & 75,89 & 208,67 & 184,99 & 27,66 & 808,06 & 474 & 2030 \\
\hline Zalaszegvár & 168 & 238,52 & 24,11 & 33,14 & 120,73 & 188,02 & 142,85 & 30,10 & 744,33 & 699 & 2463 \\
\hline Zalaszentgyörgy & 418 & 234,72 & 86,69 & 93,98 & 237,55 & 238,59 & 211,63 & 43,41 & 1052,60 & 46 & 296 \\
\hline Zalaszentjakab & 360 & 215,64 & 41,89 & 46,80 & 83,74 & 159,44 & 161,07 & 21,45 & 683,23 & 875 & 2708 \\
\hline Zalaszentlörinc & 298 & 228,87 & 55,68 & 59,33 & 154,79 & 247,10 & 202,47 & 11,49 & 900,40 & 216 & 1223 \\
\hline Zalaszentmárton & 78 & 181,11 & 49,23 & 50,08 & 78,27 & 197,85 & 190,48 & 5,34 & 702,29 & 827 & 2644 \\
\hline Zalaszombatfa & 51 & 171,53 & 39,67 & 41,27 & 128,71 & 249,93 & 167,53 & 11,35 & 768,72 & 617 & 2315 \\
\hline Zaláta & 284 & 206,56 & 39,57 & 45,29 & 157,21 & 152,83 & 157,56 & 18,63 & 732,36 & 740 & 2526 \\
\hline Zalaújlak & 111 & 151,76 & 36,03 & 35,78 & 121,83 & 267,64 & 157,32 & 5,01 & 739,58 & 715 & 2488 \\
\hline Zalavég & 401 & 184,37 & 52,46 & 45,47 & 190,69 & 238,47 & 192,22 & 25,98 & 884,18 & 262 & 1363 \\
\hline Zalkod & 263 & 159,57 & 41,41 & 45,36 & 200,88 & 198,66 & 98,57 & 0,00 & 699,09 & 838 & 2658 \\
\hline Zaránk & 450 & 180,26 & 42,36 & 52,11 & 184,78 & 210,37 & 158,32 & 14,08 & 790,16 & 546 & 2181 \\
\hline Závod & 313 & 179,00 & 62,39 & 79,34 & 195,04 & 237,16 & 171,11 & 44,74 & 889,45 & 246 & 1309 \\
\hline Zebecke & 85 & 163,94 & 18,38 & 33,80 & 100,10 & 172,22 & 173,63 & 8,66 & 636,93 & 977 & 2831 \\
\hline
\end{tabular}




\begin{tabular}{|c|c|c|c|c|c|c|c|c|c|c|c|}
\hline Településnév & $\begin{array}{l}\text { Népesség- } \\
\text { szám, } 2010\end{array}$ & $\begin{array}{l}\text { Népes- } \\
\text { ség }\end{array}$ & $\begin{array}{l}\text { Társa- } \\
\text { dalom }\end{array}$ & $\begin{array}{l}\text { Társa- } \\
\text { dalom } \\
\text { (2011) }\end{array}$ & Ellátottság & Gazdaság & $\begin{array}{l}\text { Közle- } \\
\text { kedés }\end{array}$ & $\begin{array}{l}\text { Idegen- } \\
\text { forgalom }\end{array}$ & $\begin{array}{l}\text { Összfej- } \\
\text { lettség }\end{array}$ & $\begin{array}{c}\text { H. Apró- } \\
\text { falu }\end{array}$ & $\begin{array}{c}\text { H. Fal- } \\
\text { vak }\end{array}$ \\
\hline Zengövárkony & 427 & 230,28 & 71,45 & 97,43 & 171,16 & 223,17 & 226,19 & 47,22 & 969,46 & 113 & 698 \\
\hline Zics & 393 & 188,55 & 43,74 & 48,67 & 146,99 & 163,13 & 163,93 & 18,71 & 725,04 & 762 & 2557 \\
\hline Ziliz & 390 & $\overline{197,72}$ & 37,23 & 36,62 & 159,53 & 182,30 & 187,66 & 6,28 & 770,73 & 609 & 2303 \\
\hline Zók & 294 & 236,07 & 30,86 & 38,70 & 110,35 & 220,09 & 194,10 & 100,00 & 891,47 & 239 & 1289 \\
\hline Zsarolyán & 437 & 193,32 & 27,46 & 32,78 & 131,00 & 208,17 & 153,13 & 21,22 & 734,30 & 735 & 2520 \\
\hline Zsebeháza & 135 & 180,80 & 46,03 & 63,17 & 202,17 & 299,09 & 161,85 & 38,22 & 928,16 & 162 & 980 \\
\hline Zsédeny & 205 & 191,22 & 30,67 & 47,11 & 153,99 & 239,70 & 207,25 & 49,07 & 871,90 & 287 & 1482 \\
\hline Zselickisfalud & 277 & 204,84 & 83,00 & 84,78 & \begin{tabular}{l|l|}
36,67 \\
\end{tabular} & 197,31 & \begin{tabular}{l|}
174,06 \\
\end{tabular} & 19,80 & 715,68 & 788 & 2592 \\
\hline Zselickislak & 328 & 215,85 & 72,39 & 95,71 & 166,19 & 233,64 & 216,00 & 32,41 & 936,48 & 151 & $\overline{912}$ \\
\hline Zselicszentpál & 427 & 225,62 & 65,64 & 77,31 & \begin{tabular}{l|}
143,72 \\
\end{tabular} & 236,42 & 224,01 & 17,22 & 912,63 & 197 & 1127 \\
\hline Zsennye & 107 & 228,99 & 101,86 & 112,76 & 255,01 & 253,13 & 165,38 & 49,05 & 1053,42 & 45 & 293 \\
\hline Zsujta & 188 & 198,88 & 44,41 & 56,41 & 142,41 & \begin{tabular}{l|}
156,32 \\
\end{tabular} & $\begin{array}{ll}165,74 \\
\end{array}$ & 30,00 & 737,75 & 721 & 2500 \\
\hline
\end{tabular}

a fötelepülések környékbeli falvai

2010-re belefogyott az aprófalu kategóriájába

2010-re kinőtt az aprófalu kategóriájából

$=$

Ótelepülés

H. Aprófalu helyezés az aprófalvak statisztikájában

H. Falvak helyezés a teljes faluállomány statisztikájában

A kutatás a TÁMOP 4.2.4.A/2-11-1-2012-0001 azonosító számú Nemzeti Kiválóság Program - Hazai hallgatói, illetve kutatói személyi támogatást biztositó rendszer kidolgozása és müködtetése konvergencia program címü kiemelt projekt keretében zajlott. A projekt az Európai Unió támogatásával, az Európai Szociális Alap társfinanszírozásával valósul meg. 